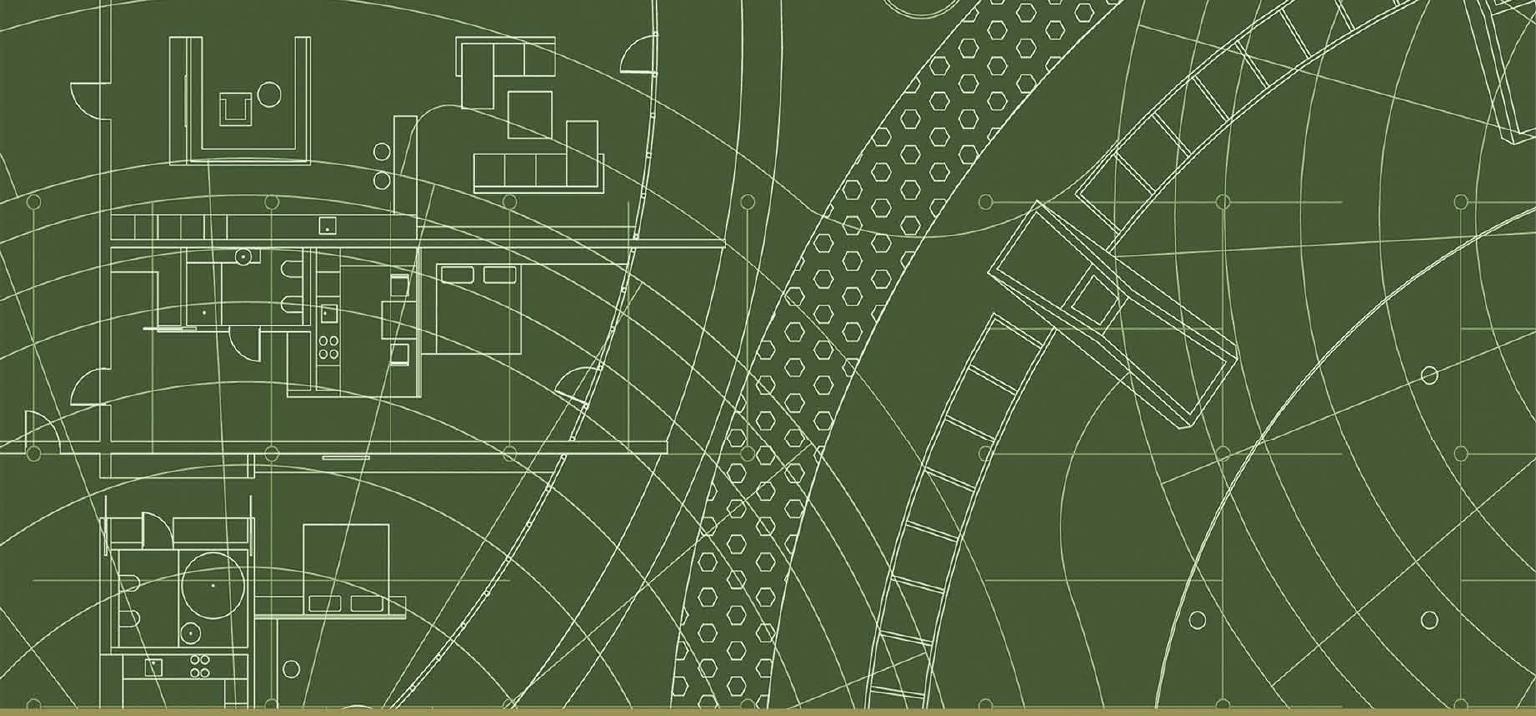

Eartbscan Studies in Natural Resource Management

\title{
FAIR AND EQUITABLE \\ BENEFIT-SHARING IN AGRICULTURE
}

REINVENTING AGRARIAN JUSTICE

Elsa Tsioumani
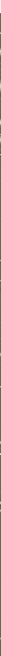


\section{Fair and Equitable Benefit-Sharing in Agriculture}

This book explores the emergence and development of the legal concept of fair and equitable benefit-sharing, and its application in agriculture.

Developed in the 1990s, the concept of fair and equitable benefit-sharing has been deployed in an ever-wider variety of international instruments, including those on biodiversity, climate change and human rights. A lack of clarity persists, however, on what fair and equitable benefit-sharing requires and entails, and whether its implementation supports or eventually undermines equity and justice. This book examines these questions in the area of land, food and agriculture, addressing for the first time several instances of the agricultural production chain, including research and development, land governance and land use and access to markets. It identifies challenges regarding implementation of the concept as enshrined in environmental treaties and soft-law instruments, with a focus on the International Treaty on Plant Genetic Resources for Food and Agriculture, the Voluntary Guidelines on Tenure and the UN Declaration on the Rights of Peasants. It investigates its role, enabling conditions and limitations, in a contradictory policy context involving environmental, food security and human rights objectives but also a growing web of multilateral and bilateral trade and investment agreements. Linking international law research with a socio-legal analysis, the book addresses four grassroots examples, which offer ideas for institutional and legal innovation from the local to the global level.

This interdisciplinary title will be of great interest to students and scholars of international environmental law, agriculture, land law, development studies and global governance, as well as policymakers and practitioners working in these fields.

Elsa Tsioumani is a post-doctoral Research Fellow at the School of International Studies, University of Trento, Italy. An international lawyer and consultant based in Thessaloniki, Greece, she has been following international negotiations on biodiversity since 1999 as a writer for the Reporting Services of the International Institute for Sustainable Development. 


\section{Earthscan Studies in Natural Resource Management}

\section{Social Movements Contesting Natural Resource Development}

Edited by John F. Devlin

\section{Benefit-sharing in Environmental Governance}

Local Experiences of a Global Concept

Louisa Parks

Governing Renewable Natural Resources

Theories and Frameworks

Edited by Fiona Nunan

\section{Interdisciplinary Collaboration for Water Diplomacy}

A Principled and Pragmatic Approach

Edited by Shafiqul Islam and Kevin M. Smith

\section{Peatlands}

Ecology, Conservation and Heritage

Ian D. Rotherham

The Moroccan Argan Trade

Producer Networks and Human Bio-Geographies

Daniel F. Robinson

Fair and Equitable Benefit-Sharing in Agriculture

Reinventing Agrarian Justice

Elsa Tsioumani

For more information on books in this series, please visit: www.routledge.com/ books/series/ECNRM/ 


\section{Fair and Equitable Benefit- Sharing in Agriculture \\ Reinventing Agrarian Justice}

\section{Elsa Tsioumani}


First published 2021

by Routledge

2 Park Square, Milton Park, Abingdon, Oxon OX14 4RN

and by Routledge

52 Vanderbilt Avenue, New York, NY 10017

Routledge is an imprint of the Taylor \& Francis Group, an informa business

(c) 2021 Elsa Tsioumani

The right of Elsa Tsioumani to be identified as author of this work has been asserted by her in accordance with sections 77 and 78 of the Copyright, Designs and Patents Act 1988.

The Open Access version of this book, available at www.taylorfrancis. com, has been made available under a Creative Commons Attribution-Non Commercial-No Derivatives 4.0 license

Trademark notice: Product or corporate names may be trademarks or registered trademarks, and are used only for identification and explanation without intent to infringe.

British Library Cataloguing-in-Publication Data

A catalogue record for this book is available from the British Library

Library of Congress Cataloging-in-Publication Data

Names: Tsioumani, Elsa, author.

Title: Fair and equitable benefit-sharing in agriculture : reinventing agrarian justice / Elsa Tsioumani.

Description: Abingdon, Oxon ; New York, NY : Routledge, 2021. | Series:

Earthscan studies in natural resource management | Includes

bibliographical references and index.

Identifiers: LCCN 2020015713 (print) | LCCN 2020015714 (ebook) | ISBN

9780367181864 (hardback) | ISBN 9780367529369 (paperback) | ISBN

9780429198304 (ebook)

Subjects: LCSH: Agricultural laws and legislation. | Sustainable agriculture-Law and legislation. | Environmental law, International. |

Agriculture and state.

Classification: LCC K3870 .T75 2021 (print) | LCC K3870 (ebook) | DDC

343.07/6-dc23

LC record available at https://lccn.loc.gov/2020015713

LC ebook record available at https://lecn.loc.gov/2020015714

ISBN: 978-0-367-18186-4 (hbk)

ISBN: 978-0-429-19830-4 (ebk)

Typeset in Times New Roman

by Wearset Ltd, Boldon, Tyne \& Wear 


\section{Contents}

Acknowledgements vi

Introduction $\quad 1$

1 Fair and equitable benefit-sharing in agricultural research and development

2 Fair and equitable benefit-sharing in land governance for sustainable agriculture

3 Moving beyond fair and equitable benefit-sharing

4 Exploring grassroots initiatives from the seed to the landscape

5 Conclusions and a research agenda

Index 


\section{Acknowledgements}

My thanks go first to the BeneLex team, including PI Elisa Morgera, a great scholar and friend, Annalisa Savaresi, Kim Bouwer, Margherita Brunori, Daniela Diz, Saskia Vermeulen and Louisa Parks; it was a fascinating journey and learning experience. Louisa, travelling with you to Ikaria opened a whole different world of perspectives (plus it was great fun!) and for that I am grateful.

My three visits to Ikaria, for the 2013 Mataroa seminar 'against the crisis, for the commons' and during BeneLex, were deeply transformative, and for this I am indebted to Maria Bareli and Frosini Koutsouti. I also want to thank Alejandro Argumedo for several conversations over the years on the Potato Park and life in general; Michael Halewood for guidance on participatory plant breeding; and Vasso Kanellopoulou for sharing her experiences and insights from the Peliti community.

Several BeneLex advisors provided me with ideas and inspiration over the years. I want to thank in particular Christine Frison, Ellen Hey, Colin Reid, Shakeel Bhatti, Harry Jonas, Claudio Chiarolla and Thierry Berger. I am deeply grateful to Lorenzo Cotula, without the guidance and work of whom I would never have written the chapter on land, and to Alexandra Elbakyan, for her efforts to set knowledge free.

The School of International Studies at the University of Trento offered me an academic home for this year of writing and a series of stimulating knowledge exchanges, and for this I want to thank Andrea Fracasso, Anna Casaglia, and Louisa Parks, again.

My thanks also go to my colleagues and friends at the Reporting Services of the International Institute for Sustainable Development, for the hours spent over intergovernmental negotiations and their outcomes, and my friends and partners at our Law Collective in Thessaloniki who gave me their full support. I also want to thank my editors Hannah Ferguson, Amy Louise Johnston and John Baddeley for their support and patience.

I wouldn't be who I am without my friends: Mike M., Grigoris G., Eleni R., Stefanos A., Stergios T., Klea D., Despina D., Marina K., Dimitris P., Sakis B.; thank you.

I owe a lot to my mother and Anastasia, for everything. 


\section{Introduction}

This book is the outcome of research conducted as part of the five-year-long BeneLex project, ${ }^{1}$ which investigated the conceptual and practical dimensions of fair and equitable benefit-sharing in different areas of international law. Research included a desk study of relevant international law and academic literature; analysis of and contribution to various streams of international negotiations; and local-level field work to identify priorities and challenges for indigenous peoples and local communities in benefit-sharing implementation, and the interface between local, national, regional and international law. It involved an interdisciplinary research team of three international lawyers and a political sociologist. My part of the research focused on the area of land, food and agriculture, and the outcome is reflected in the following chapters.

The concept of fair and equitable benefit-sharing was developed in the 1990s in international biodiversity law, and particularly the field of genetic resource utilization for research and development, following adoption of the Convention on Biological Diversity (CBD). ${ }^{2}$ Bioprospecting - the search for plants and animals from which commercially valuable compounds can be obtained for use in agriculture, medicine or cosmetics - is often a transnational activity; it involves situations where genetic resources are found in one state but are used in another. Most of the world's biodiversity is found in developing countries, whereas developed countries usually host research institutes and companies that make commercial use of this biodiversity. The concept of fair and equitable benefit-sharing concerns the fair and equitable allocation of benefits arising from the use of genetic resources among providers (countries rich in biodiversity and genetic resources and indigenous peoples and local communities holding related knowledge) and users (companies and institutions using such resources to develop marketable products). Benefit-sharing was thus conceived as a tool for ensuring equity and sustainable development given the asymmetries in terms of power, information and finances that often persist between states providing and those using genetic resources. The idea was quite simple: developing countries host most of the world's biodiversity and thus genetic resources; commercial products developed on the basis of these genetic resources mostly benefit companies and consumers in developed countries; some of these benefits should flow back to the countries of origin of genetic resources and to their peoples and 


\section{Introduction}

communities who have contributed to their conservation (Morgera, Tsioumani and Buck 2014). This inter-state dimension of benefit-sharing was accompanied by its intra-state dimension, with regard to a state obligation to return part of the benefits arising from the use of traditional knowledge to the indigenous peoples and local communities who were the stewards of such knowledge (Morgera and Tsioumani 2010).

Since then, the concept has been deployed in several international treaties and soft-law instruments, including on food and agriculture, climate change and human rights. In addition, the Nagoya Protocol on Access and Benefit-Sharing, ${ }^{3}$ adopted under the auspices of the CBD, operationalized the CBD objective on fair and equitable benefit-sharing through provisions on benefit-sharing obligations arising from the use of genetic resources and traditional knowledge, access to genetic resources upon prior informed consent and mutual agreed terms and compliance. In the field of agricultural research and development, the International Treaty on Plant Genetic Resources for Food and Agriculture (ITPGRFA) ${ }^{4}$ established the Multilateral System on access and benefit-sharing, explored in detail in the following chapter. Lack of clarity persists, however, on the main elements of the concept of benefit-sharing in different areas of international law, as well as its requirements and preconditions. Another fundamental question is whether its implementation in practice supports or eventually undermines equity and justice.

In the following chapters, I track and assess the emergence and application of fair and equitable benefit-sharing in land, food and agriculture in several instances of the agricultural production chain, including research and development, land governance and land use and access to markets. Through a series of conceptualizations and illustrations reflected in specific case studies or examples of national-level implementation efforts, I explore its role, enabling conditions and limitations in promoting global objectives such as food security, sustainable agriculture and environmental sustainability, as well as more general principles such as legal empowerment and social justice. Concluding that the concept falls short of its promises to inject fairness and justice in agricultural development due to a contradictory policy context, I then explore four examples coming from the grassroots, which offer ideas for institutional and legal innovation. The analysis is based on a desk study of international law and a literature review, empirical analysis of several sessions of intergovernmental negotiations under the CBD and the ITPGRFA and some interviews with actors involved in the grassroots initiatives explored.

In the first chapter, I start by exploring the emergence of the concept of fair and equitable benefit-sharing in the context of the evolving principles of governance of agricultural biodiversity. I analyse the structure and application of the Multilateral System (MLS) of the ITPGRFA for access to, and fair and equitable benefit-sharing (ABS) from the use of, plant genetic resources. I place this analysis in the context of intellectual property rights (IPR) and human rights instruments, starting from the lack of benefit-sharing applications in IPR instruments and exploring human rights concerns and discourses related to political 
and ethical considerations. These overlapping regimes result in a complex legal and policy landscape of conflicting objectives, rights and policies. To illustrate this complex landscape, I use a case study: the case of patent applications submitted by the International Rice Research Institute on breeding methods associated with a rice gene isolated in an Indonesian farmers' variety.

In the second chapter I investigate use of the concept of benefit-sharing in land governance for food and agriculture purposes, with a particular focus on farmers' rights and benefit-sharing from public lands, including in the case of large-scale agricultural investments. I start by outlining fundamental elements that differentiate the regulation of benefit-sharing from land use compared to benefit-sharing from genetic resource use for research and development, related to the nature of the resource, the scope of the regulation and the determination of beneficiaries. I draw a general picture of the trends behind land governance, including linkages between land distribution and social justice, gender as a decisive element of land poverty, the central role of national law and interactions between formal and customary tenure systems and the emergence of international regulation, including human rights and investment law. I then trace the emergence of the concept of fair and equitable benefit-sharing of relevance to land governance in environmental treaties, including the $\mathrm{CBD}$ and the $\mathrm{UN}$ Convention to Combat Desertification (UNCCD). I explore in detail specific applications of benefit-sharing with regard to farmers' rights in the context of the ITPGRFA, human rights including the right to food and the UN Declaration on the Rights of Peasants, and implementation challenges in view of seed and variety certification and marketing regulations. I propose a broad construction of farmers' rights to include supporting elements and enabling conditions, including land rights and access to markets. I conclude the analysis with a case study on the international policy framework on access to markets and linkages with farmers' rights and benefit-sharing. I then pass to applications of benefit-sharing from the use of public lands. I present basic categorizations and challenges arising from overlapping formal and customary tenure systems and the trend of largescale agricultural investments, and focus on the emerging legal basis, including the Voluntary Guidelines on the Responsible Governance of Tenure and human rights instruments, and specific implementation efforts. I conclude the analysis with a discussion of competing land uses and benefit-sharing on the isle of Ikaria, Greece.

In the third chapter, I distil a series of linkages, key lessons and challenges related to the conceptualization and implementation of fair and equitable benefitsharing, as arising from the first two chapters. I conclude that the concept falls short of its promises to inject fairness and justice in agricultural development, at least as currently applied in the current contradictory policy context, which fails to support user-based innovation and poses a host of obstacles to smallholders. I argue, however, that it has the potential to contribute to sustainable agriculture and rural livelihoods objectives, if constructed broadly to cover a series of supportive elements and enabling conditions. I thus stress the need to move 


\section{Introduction}

beyond narrow or strictly monetary understandings of benefit-sharing, highlight the role of social movements as driving forces of international law development and call for drawing inspiration from the sharing ethos of grassroots communities to enrich the concept of fair and equitable benefit-sharing in international law.

The fourth chapter explores four examples coming from the grassroots, which enrich the concept of fair and equitable benefit-sharing, offering ideas for institutional and legal innovation: the concept of participatory plant breeding; open-source applications in agricultural research and development, with a focus on the Open Source Seed Initiative; the Peliti community in Greece, a network of local groups working on the conservation and exchange of traditional varieties; and the Potato Park in the Peruvian Andes, an indigenous biocultural heritage area based on a sui generis legal system combining customary laws with concepts of international environmental law. The discussion of the case studies marks the beginning of upcoming research on the legal context enabling or not such initiatives, legal tools used and conditions for their success. In this context, I identify trends and ask questions involving the role of law, communitybuilding and enabling conditions and elements linking the local to the global and vice versa.

In the final chapter, I outline a series of considerations arising from the analysis of the international legal landscape on fair and equitable benefit-sharing in land, food and agriculture, including challenges and shortcomings in its implementation in various contexts. I further highlight lessons learnt from the preliminary analysis of the grassroots-level case studies presented in the previous chapter, with focus on the role of law, legal and institutional prerequisites for benefit-sharing and the concept of community. A series of elements arising from the grassroots could provide inspiration for various intergovernmental processes within and beyond the international environmental law realm. I finally propose a research agenda towards agrarian justice, integrating and re-imagining global objectives concerning sustainable agriculture, rural livelihoods and environmental sustainability.

\section{Notes}

1 Benefit-sharing for an equitable transition to the green economy - the role of law, European Research Council Starting Grant 335592 (November 2013 - October 2018) led by Elisa Morgera. Project webpage is available at: www.strath.ac.uk/research/strath clydecentreenvironmentallawgovernance/benelex/ (last accessed 1.3.2020).

2 Convention on Biological Diversity of 5 June 1992, entered into force on 29 December 1993, 1760 UNTS 69.

3 Nagoya Protocol on Access to Genetic Resources and the Fair and Equitable Sharing of Benefits Arising from their Utilization to the Convention on Biological Diversity of 29 October 2010, entered into force on 12 October 2014, UN Doc UNEP/CBD/COP/ $\mathrm{DEC} / \mathrm{X} / 1$.

4 International Treaty on Plant Genetic Resources for Food and Agriculture of 3 November 2001, entered into force on 29 June 2004, 2400 UNTS 303. 


\section{References}

Morgera, E. and Tsioumani, E. (2010) 'The Evolution of Benefit-Sharing: Linking Biodiversity and Community Livelihoods', Review of European Community and International Environmental Law 19(2): 150-173.

Morgera, E., Tsioumani, E. and Buck, M. (2014) Unraveling the Nagoya Protocol: A Commentary on the Nagoya Protocol on Access and Benefit-Sharing to the Convention on Biological Diversity. Leiden: Brill. 


\section{Fair and equitable benefit-sharing in agricultural research and development}

\section{Introduction}

In this chapter, I first explore the emergence of the concept of fair and equitable benefit-sharing in the context of the evolving principles of governance of agricultural biodiversity. I then analyse the structure and application of the Multilateral System (MLS) of the International Treaty on Plant Genetic Resources for Food and Agriculture (ITPGRFA) for access to, and fair and equitable benefit-sharing (ABS) from the use of, plant genetic resources. I place this analysis in the context of intellectual property rights (IPR) and human rights instruments, starting from the lack of benefit-sharing applications in IPR instruments and exploring related human rights concerns and discourses related to political and ethical considerations. The result showcases a complex legal and policy landscape of conflicting objectives, rights and policies. To illustrate this complex landscape, I use a case study: the case of patent applications submitted by the International Rice Research Institute on breeding methods associated with a rice gene isolated in an Indonesian farmers' variety. This exploration will eventually assist in assessing the potential of the concept of fair and equitable benefit-sharing in promoting and operationalizing fairness and equity in agricultural research and development.

\section{The evolution of the global governance of plant genetic resources}

\section{Informal seed systems and public agricultural research}

Since the earliest crop domestications, agricultural development has been based on farmers' traditional varieties, developed through collective systems of innovation and conservation through seed saving, sharing and use (Halewood et al. 2013a). Exchanges were regulated on a customary basis, largely at the community level, and included both informal ones and more organized systems, such as seed fairs and community seed banks (Garine et al. 2018).

The literature on the historic events which led to the global redistribution of plant genetic resources for food and agriculture (PGRFA) and the emergence of international regulation is vast, so I make a very schematic reference. 
Colonization resulted in a vast flow of agricultural species from the Americas to Europe and from South to North. Ex situ facilities were established in the North, such as botanic gardens and genebanks, which stored samples of agricultural varieties coming mainly from developing countries, the centres of domestication of major agricultural crops. These samples provided the basis for the high-yielding varieties of crops developed during the green revolution in the twentieth century.

The green revolution dramatically transformed agriculture through scientific and technological advances, and led to increased food production at least in some regions. It also marked the emergence of professional plant breeding and the commercial seed sector, leading to the marginalization of customary farmer practices and varieties and traditional seed systems, in favour of scientific, public or corporate-led research, in cases putting at risk the livelihoods of smallholder farmers (Tsioumani et al. 2016; De Schutter 2009; Mooney 1998). Such socio-economic impacts were accompanied by environmental ones. The spread of monocultures of high-yielding, genetically uniform crop varieties led to the erosion of agricultural biodiversity, making agricultural production vulnerable in the face of threats such as pests and extreme environmental conditions (FAO 1993; Dahlberg 1979; Glaeser 2011).

It was the need for continued exchanges of PGRFA samples to develop the varieties to fuel the green revolution, as well as the realization of the risks of genetic erosion, that provided the rationale for the international regulation of PGRFA (Halewood et al. 2013a; Scarascia-Mugnozza and Perrino 2002). The first technical conference, which placed PGRFA on the international agenda, was held by the Food and Agriculture Organization of the UN (FAO) in 1967. Following arduous debates, the conference expressed preference for ex situ conservation methods (thus conservation of samples in genebanks) over on-farm management, referring to the sustainable management of local diversity by farmers as part of their agricultural practices (Maxted et al. 2011). However, it reached no agreement with regard to coordinated actions (Pistorius 1997; Halewood et al. 2013a).

The first institutionalized international structure on PGRFA conservation and management, the Consultative Group on International Agricultural Research (CGIAR), was created in 1971 as a result of a World Bank initiative, and eventually gathered several international agricultural research centres under its auspices, with the co-sponsorship of FAO and the UN Development Programme (UNDP) (Özgediz 2012). With a focus on ex situ conservation of crops of agroeconomic value, the CGIAR centres stored a large percentage of the world's PGRFA, which under various circumstances had flowed from the developing to the developed world (Fowler 1994; Fowler et al. 2000; Chiarolla 2012).

At the time, international law was silent with respect to the conditions for access to and use of PGRFA, both in situ (on-farm and in nature in general) and in the CGIAR system; similarly, most national legislations did not regulate access to PGRFA, either in situ or in genebanks. PGRFA were thus considered to be in the public domain, available to anyone for any purpose, without benefit-sharing 


\section{Benefit-sharing in agricultural research}

or conservation obligations (Halewood et al. 2013a). In turn, most agricultural research at the time was conducted by public institutions, and the results of the work were shared (Rose 2004). The CGIAR committed to the free circulation of both original and improved material and the full sharing of information (Byerlee and Dubin 2009), with the belief that the benefits of such a system would flow to humanity at large in the form of agricultural development and scientific progress. Data indicates that developing countries were the main recipients of germplasm samples from the CGIAR centres and thus beneficiaries of the system (Fowler et al. 2000).

The CGIAR approach can be criticized for its focus on ex situ conservation, which, apart from its own technical problems (Louafi et al. 2013), resulted in marginalizing on-farm management, thus farmers' knowledge, varieties and practices, and in promoting monocultures in the name of increased productivity. In addition, what remains into question (and partly addressed later in this book) is whether such a narrow, centralized model of agricultural innovation based on a Western type of agricultural knowledge and development can fit the needs of all users, particularly smallholders, and whether it can promote localized objectives related to livelihoods and biodiversity conservation. At the time, though, what eventually challenged the CGIAR practices was the growing application of intellectual property rights (IPRs) and the gradual privatization of agricultural research and development.

\section{The first wave of privatization}

The introduction and continuing strengthening of IPR protection for modern agricultural varieties catalyzed multiple changes in the course of international regulation of PGRFA. IPRs are supposed to foster and reward creativity and innovation, including to address global challenges such as food security. The IPRs mainly in use in the field of agricultural innovation are plant breeders' rights (PBRs) and patents. I briefly introduce them below, in turn.

PBRs were established at the time of the green revolution by the 1961 International Convention for the Protection of New Varieties of Plants (UPOV Convention), later amended in 1972, 1978 and 1991. According to its mission statement, the International Union for the Protection of New Varieties of Plants (UPOV), established by the UPOV Convention, aimed to encourage the development of new varieties of plants for the benefit of society. PBRs provide protection to novel (in terms of prior commercialization), distinct, uniform and stable plant varieties. These standards were specifically developed to support protection of modern varieties. Farmers' varieties are generally neither uniform nor stable, and the existing ones (those used for the development of modern varieties) do not satisfy the novelty requirement and are considered as 'prior art' within the public domain. In addition, the uniformity criterion in particular has been subject to criticism because it reinforces trends towards genetic uniformity, and a higher degree of genetic vulnerability (Silva Repetto and Cavalcanti 2000).

The 1978 version of the UPOV Convention (UPOV 78) provided for two exemptions to plant variety protection, aiming to guarantee the continued 
exchange of material for further research and to protect smallholder farmers' livelihoods: the breeders' exception and the farmers' privilege. The breeders' exception permitted the use of protected varieties as the source material of further breeding; the farmers' privilege allowed the re-use of saved seeds by subsistence farmers. However, as examined below, these exemptions were restricted in the 1991 version of the UPOV Convention (UPOV 91). UPOV membership was further boosted with the adoption of the Agreement on TradeRelated Aspects of Intellectual Property Rights (TRIPS Agreement) by the World Trade Organization (WTO) in 1994, and later through bilateral and multilateral free-trade agreements, as addressed below.

Patents in the field of plant breeding were first allowed through the 1930 US Plant Patent Act. They gradually took off following the 1980 US Supreme Court case of Diamond v. Chakrabarty, ${ }^{1}$ which opened the way to the patenting of genetically modified organisms (Kevles 1994; Carolan 2010; Jasanoff 2001) and expanded dramatically following adoption of the TRIPS Agreement and the breakthrough of modern biotechnology in the 1990s, although they remain controversial from a political and ethical point of view, as examined below. Protecting plant-derived innovations under patent regimes requires an applicant to demonstrate novelty, an inventive step and the potential for industrial application. Farmer varieties obviously do not satisfy these requirements. Patents provide the strongest form of intellectual property protection, in the sense that they normally allow the patent holder to exercise the greatest control over the use of patented material. Thus, exceptions aiming to protect farmers' and breeders' activities are usually more limited under patent law than under PBR legislation. At the moment, to my knowledge, patents on conventional plant varieties are only allowed in the USA, Japan, Australia and the Republic of Korea.

Privatization was a major attack to the previous treatment of PGRFA and related knowledge as public goods. In the words of Charlotte Hess, 'IPRs appear to slow the free flow of germplasm exchange, slow the diffusion of new knowledge, upset the balance between basic and applied research, and erode scientific integrity' (Hess 1993: 128), posing obstacles to public research. Alongside concerns regarding commodification of PGRFA, the beginning of privatization of genetic resources resulted in a major asymmetry between the stewards of these resources and those who benefitted more from their use, arguably private companies in developed countries. Farmers' varieties and PGRFA originating in biodiversity-rich developing countries were to be exchanged freely as the basis for development of modern varieties, while the availability of the resulting varieties was restricted by IPRs (Mooney 1983: 24). This was considered as unfair and inequitable or at least morally unjust from the perspective of provider countries and farmers, and was at the core of the tensions that challenged CGIAR practices. These concerns have been exacerbated by the (mis)application of the IPR system, dubbed as 'biopiracy'. ${ }^{2}$ Patents have been granted on genetic resources obtained from developing countries, often without the knowledge and consent of the country of origin and hardly any demonstration of an inventive step. 
There has been extensive documentation of IPRs being sought over resources in the form they are found in nature or in farmers' fields, without further improvement, or on products based on plant materials and knowledge developed and used by indigenous peoples and local communities. Examples concern the Mayocoba (or Enola) bean, quinoa, neem tree and turmeric (Mooney 1998; Aoki 1998). In the case of the Mayocoba bean, for example, a US patent was granted on a bean variety widely cultivated in Mexico, originating from the CGIAR centres, which it took nine years of litigation to revoke (CIAT 2009). There are no specific standards of what is considered a 'novelty' or an 'invention' for the purpose of patent registration. Assessment of the level of inventive step required to grant a patent is crucial to determine the extent to which patents on genetic resources may be lawful or not. In addition, a basic issue has been whether isolated genes and other biological materials may be deemed 'invented' and thus eligible for patent protection. Approaches differ among national jurisdictions, along with debates on ethical considerations (Nuffield Council on Bioethics 2002). From a global perspective, these points have increased significance.

In the context of rising tensions about the potential impact of IPRs on the legal status of the CGIAR collections, the need for some form of legal arrangement regarding access to and use of samples from these collections was acknowledged. This resulted in the adoption of the International Undertaking on Plant Genetic Resources for Food and Agriculture, examined in the next section.

\section{The attempt for a common heritage approach}

Adopted by the FAO Conference in 1983, the non-binding International Undertaking (IU) attempted to apply the principle of common heritage to PGRFA, declaring that "plant genetic resources are a heritage of mankind and consequently should be available without restriction' (IU Art. 1). Significantly, the principle of common heritage would cover all plant genetic resources, including 'newly developed varieties' (Art. 2(1)). The initial strategic and legal response was thus to make all PGRFA, including improved varieties, freely accessible to farmers and breeders around the world (Kloppenburg 2014; Aoki 2009), attempting to bypass IPRs. This - retrospectively radical - approach can be explained in the light of the asymmetry introduced by IPRs: the main problem was not that seed companies were using PGRFA for free, but that they were restricting access to the improved varieties that, as a matter of reciprocity, ought to have been shared.

The 'common heritage of mankind' is an ethical concept and (controversial) international law principle establishing that some spaces and resources belong to all humanity and are available for everyone's use and benefit, taking into account future generations and the needs of developing countries for sustainable development (Taylor 2012). Application of the concept in the framework established by the Undertaking sought to benefit humanity as a whole, and 'to support major increases in agricultural production, especially in developing countries' (IU Art. 7(h)(ii)). Distribution of the benefits was left to national governments' responsibility, and no mechanism was established to address the needs of specific fractions 
of humanity, importantly the most vulnerable or developing countries less equipped for agricultural research and development. An internationally coordinated network of centres, including the pre-existing CGIAR centres, would operate under the FAO auspices and assume the responsibility to hold PGRFA collections 'for the benefit of the international community and on the principle of unrestricted exchange' (IU Art. 7(a)). The absence of formal benefit-sharing arrangements lies in the strong belief that benefits would flow to developing countries in the form of distribution of PGRFA and related information. Noble in its intentions, the architecture seemed to ignore the global inequities regarding distribution of the infrastructures, knowledge and skills, which are necessary to make use of an open system such as the one created by the Undertaking (Louafi and Welch 2014). It further revealed the central weakness of the common heritage approach in international law: that it is largely motivated by states' desire for access to resources rather than by genuine community interest in their protection (Brunnée 2008).

The International Undertaking did not resolve the impasse between developed and developing countries largely associated with IPRs and equity-related concerns. Despite its non-binding nature, it was revolutionary enough to provide reasons to eight developed countries to sign it with reservations, ${ }^{3}$ reluctant to allow the principle of common heritage to apply to modern varieties, and concerned it would undermine plant breeders' rights. Developing countries, in turn, considered impractical the attempt to apply the principle of common heritage against IPRs. Identifying themselves as providers and thus owners of genetic resources, they pushed for application of the principle of national sovereignty over natural and genetic resources. It came as no surprise that the principle of common heritage was rejected in the negotiations that led to the adoption of the Convention on Biological Diversity (CBD) (addressed in the next section), which affirms instead that the conservation of biodiversity is a common concern of humankind, indicating that it is an issue involving global responsibilities and requiring global cooperation.

If IPRs created a major enclosure to the previous systems of exchange, the principle of national sovereignty over natural and genetic resources aimed to defend the rights of countries providing such resources by creating a second, defensive enclosure. In the words of Michael Halewood and his colleagues, 'if developed countries were able to exercise restrictive control over advanced biologically based technologies using intellectual property rights, developing countries could exercise their sovereign rights to regulate and restrict access to the biological and genetic resources within their borders' (Halewood et al. 2013b: 6). Aiming to ensure some portion of the benefits arising from the use of their resources, developing countries pushed for a major shift in the regulation of access to such resources. This shift was embedded in the CBD, addressed in the following section.

\section{The nationalization trend}

The CBD, a legally binding treaty adopted in 1992 at the Rio Earth Summit, recognizes that the authority to determine access to genetic resources rests 


\section{Benefit-sharing in agricultural research}

with national governments and is subject to national legislation. The CBD includes prominently among its objectives the fair and equitable sharing of the benefits arising from their commercial or other utilization. Aiming to establish a system for bilateral exchanges of genetic resources between providers and users, it subjects access to the prior informed consent of the country providing such resources, and to mutually agreed terms for benefitsharing. Benefit-sharing is thus linked to the principle of national sovereignty, and appears to have a balancing function against the privatization of genetic resources via IPRs.

The shift in principles can be further justified due to the growing expectations of the commercial value of biodiversity (Petit et al. 2001; Batta Bjørnstad 2004) and the potential use of such gains for development purposes (Raustiala and Victor 2004). The emergence of the biotechnology industry in the 1990s and of a market for biodiversity-based products was at the centre of these expectations. Arguably marking the emergence of market-based approaches to biodiversity management (Morgera 2016), benefit-sharing can thus be conceptualized as a development tool, to reap part of the gains of the biodiversity market, as well as an incentive for stewards of biodiversity, including biodiversity-rich developing countries, indigenous peoples and smallholder farmers, to reward them and enable their continued contribution to conservation.

The influence of the $\mathrm{CBD}$ on the FAO realm was immediate; even before finalization of the CBD negotiations, the 1991 FAO conference adopted Resolution 3/91 endorsing that nations have sovereign rights over their plant genetic resources, and recognized that the concept of common heritage as applied in the International Undertaking is subject to the sovereignty of the states over their plant genetic resources. At the same time, it implicitly addressed benefit-sharing by stating that the availability of plant genetic resources and the information, technologies and funds necessary to conserve and utilize them are complementary and of equal importance, and by establishing an international fund to support plant conservation and utilization programmes and implement farmers' rights.

In addition, conflicts about the legal status of the CGIAR collections continued. In the early 1990s, widely publicized rumours had it that the World Bank may appropriate the collections, or that the host countries may seek to control them, or that the centres themselves may seek to do so. Under pressure to end such controversies, in 1994 the CGIAR centres eventually signed agreements with the FAO, placing their collections within the international network of the International Undertaking. They affirmed that they held their collections 'in trust for the benefit of the international community', and that they would not claim legal ownership or IPRs over the germplasm (Halewood et al. 2013a).

Adoption of the CBD was considered a major victory for the global South, but were developing countries accurate in their expectations? Would adoption of the TRIPS Agreement mean that many of these gains were weakened (Aoki 2009)? The next section will explore the second wave of privatization, marked by a strengthening of PBRs, a continuous expansion of the patentable subject 
matter and bilateral and multilateral pressures on developing countries to ratify IPR-related treaties.

\section{Privatization 2.0}

As explained above, the IPRs mainly in use in the field of agricultural development are PBRs and patents. A series of interlinked policy and technological developments in the 1990s marked the beginning of their dramatic expansion: the restriction of exemptions to PBRs in UPOV 91; adoption of the TRIPS Agreement by the WTO in 1994; the breakthrough of modern biotechnologies; and the proliferation of bilateral and multilateral free-trade agreements. These are briefly addressed below.

As noted above, the model of PBRs as epitomized by UPOV 78 clearly permitted the use of protected varieties as the source material of further breeding (breeders' exception) and the re-use of saved seeds by farmers (farmers' privilege) (Correa 1999). Both are important mechanisms to protect farmers' livelihoods, allow for farmer-led innovation based on traditional seed-saving and exchange practices and in general guarantee the continued exchange of material for public research and global food security purposes. These exceptions, however, were restricted in UPOV 91. As explored in detail below, the plant breeders' exception was preserved, acts done 'privately and for non-commercial purposes' or 'for experimental purposes' were also exempted, but the farmers' privilege for replanting was restricted while the scope of protection for the PBR holder was extended beyond the propagating material of protected varieties to include 'essentially derived varieties'. According to this amendment, farmers were required to limit the amount of saved seeds or to pay an equitable remuneration to the PBR holder. In addition, use of protected varieties by farmers is permitted only for propagating and planting on their own holdings, but not for informal sale, thus also restricting exchanges among farmers (Chiarolla et al. 2013).

UPOV membership was boosted with the adoption of the TRIPS Agreement. According to TRIPS Agreement Article 27(3)(b), WTO member states are required to provide for the protection of plant varieties either by patents or by an effective sui generis system, a Latin term which refers to a system that is unique, of its own kind. According to the option regarding a sui generis system, countries should be free to identify an IPR system to suit their particular agricultural and socio-economic conditions and priorities. However, the UPOV Convention provides a ready-made sui generis framework; it therefore appears as an obviously easy choice (Correa et al. 2015). Ratification seems to be promoted also by technical advice provided to developing countries (De Schutter 2009). Developing-country membership is thus constantly increasing, despite the fact that the UPOV system is tailored to the needs of the commercial seed sector and the commercialized farming systems of the developed countries rather than the diversified agriculture of the developing ones, often supporting subsistence purposes (Yamin 2003; Commission on Intellectual Property Rights 2002). 


\section{Benefit-sharing in agricultural research}

Patentability of living organisms, including plant varieties, has always involved political questions and ethical considerations, and is rejected in several jurisdictions, while the global discussion remains open (see below). The breakthrough of modern biotechnologies marked a dramatic expansion of the patent subject matter, with an ever-increasing number of patents to cover not only transgenic plants but also particular plant traits and parts, components such as genes, plant breeding methodologies and vectors and processes involved in the production of transgenic plants (Aoki 2009). Geographical application also expanded, as transgenic plants became patentable in Europe under the terms of the Directive 98/44/EC on the legal protection of biotechnological inventions (Crucible II Group 2000; Dutfield 2010). ${ }^{4}$

Some examples can usefully illustrate the breadth of patents currently granted (Tsioumani et al. 2016). In February 2010, US-based company Mendel Biotechnology won a patent in the USA on plant transcriptional regulators, a class of genes that control the degree to which other genes in a cell are activated. These genes reportedly confer improved stress tolerance in genetically engineered plants, not for a single abiotic stress, but for drought, shade and lownitrogen conditions, and extend to virtually any transgenic plant and seed encoding a specified DNA sequence. The BASF's patent in the USA on 'transcription factor stress-related proteins and methods of use in plants' lays claim to transgenic plants transformed with isolated DNA sequences that confer increased tolerance to environmental stress, including salinity, drought and temperature, and covers virtually all flowering plants, such as maize, wheat, rice, soybean, potato and tomato, to mention only some. Monsanto's international patent application, published by the World Intellectual Property Organization (WIPO) in February 2010, describes novel proteins derived from bacterial coldshock proteins, which, upon expression in transgenic plants, provide the plants with enhanced stress tolerance to heat, salt and drought. The application makes extremely broad claims, not just to the modified plant cells that exhibit improved stress tolerance but also the processed product derived from the transgenic plant. All these extremely broad patents refer to plant components and processes which could be relevant for adapting agricultural research and production to the challenges of climate change (ETC Group 2010).

Furthermore, while the number of patent applications is increasing annually in both the USA and Europe, the number of applicants is decreasing. Dozens of mergers, acquisitions and strategic alliances since the 1980s have resulted in a dramatic concentration of control in a handful of companies, sparking concerns regarding undue control of global food production, privatization of agricultural research and, as a result, risks for food security (Tsioumani et al. 2016). The degree of concentration in the agrochemical sector is described in the literature as 'dramatic', leading to a 'pervasive restructuring' of the plant breeding sector (Aoki 2009). According to research by the ETC Group published in 2010, the top ten seed companies at the time accounted for $67 \%$ of the global proprietary seed market; the world's largest seed company alone, Monsanto, accounted for $23 \%$ of that market; the top three companies (Monsanto, DuPont and Syngenta) 
accounted for 47\% (ETC Group 2010). In addition, a handful of big firms own most key enabling technologies. Ownership of patents on enabling technologies enhances their market power, ties smaller companies to them and also acts as a barrier to market entry (Hope 2004). More recent developments show progressive growth of corporate consolidation, particularly following the 2015-2016 wave of mergers and acquisitions: the two US corporations DuPont and Dow Chemical merged; ChemChina bought the Swiss company Syngenta; the German chemical giant Bayer took over the US company Monsanto. This means that three conglomerates would control more than $60 \%$ of the market for commercial seed and agricultural chemicals, supply almost all genetically modified (GM) varieties and own the majority of patent applications for plants (Bonny 2017; Moldenhauer and Hirtz 2017). In fact, literature suggests that the two phenomena of patent expansion and market concentration may be more tightly linked than one thinks. Janet Hope, for instance, argues that the 'merger-mania' has been driven primarily by the need to avoid high transaction costs associated with clearing multiple IPRs (Hope 2004). As explored in the fourth chapter, researching and negotiating the IPRs that potentially surround the material and methods of their work in order to obtain 'freedom to operate' is a substantial transaction cost for breeders, often prohibitive for public-sector ones.

Finally, in recent years, developed countries, particularly the EU and the USA, have exerted bilateral pressure to developing countries to ratify UPOV 91, adopt UPOV-complying legislation, or even introduce patent protection for plants, animals and biotechnological innovations that exceeds the TRIPS standards (Helfer 2004). To provide some examples, according to their free-trade agreements (FTAs) with the EU, Morocco and Lebanon must join UPOV 91. The USA-Morocco FTA contains an obligation to make patents available for plants and animals, while the FTAs of the USA with Chile, Peru and Colombia include 'best endeavour clauses' to make available patents for plants (Heath and Kamperman Sanders 2007; GRAIN 2014; Correa 2009; Brennan and Kilic 2015).

These developments illustrate the dramatic change of the legal, political and economic landscape that has taken place since adoption of the CBD. The following section will explore the status and applications of the concept of fair and equitable benefit-sharing in the environmental and IPR-related instruments governing agricultural research and development.

\section{Status and applications of fair and equitable benefit- sharing in agricultural research and development}

The current picture of the international governance of agricultural research and development is largely defined by the CBD, the ITPGRFA and IPR-related instruments. While fair and equitable benefit-sharing is an objective of environmental treaties and the focus of sophisticated regulation efforts, the concept is not enshrined in the IPR instruments. This section will thus examine and assess critically the structure, implementation and review process of the ITPGRFA 
Multilateral System (MLS) of access and benefit-sharing, which was negotiated to respond to the adoption of the CBD and developed to address the specificities of agricultural biodiversity. It will also explore the lack of benefit-sharing applications in IPR instruments, the status of relevant ongoing negotiations in the WTO and WIPO and related human rights concerns, together with political and ethical considerations.

\section{The ITPGRFA Multilateral System of access and benefit-sharing}

As noted above, the CBD negotiations had an immediate influence on the FAO realm. With the adoption of the $\mathrm{CBD}$, the Nairobi Final $\mathrm{Act}^{5}$ recommended adjusting the International Undertaking in line with the $\mathrm{CBD}$, providing the basis for the negotiations of the ITPGRFA.

\section{Rationale and structure}

Why a treaty specifically on PGRFA? The rationale is to some degree described in the preamble to the Treaty. The MLS aimed to respond to the specificities of agricultural biodiversity and the 'public good' nature of PGRFA and basic scientific research in general (Cooper et al. 1994; Halewood et al. 2013b), for which the CBD bilateral system of exchanges was considered unsuitable (Chiarolla et al. 2013). Continued PGRFA exchange is indispensable for the continuation of agricultural research for sustainable agriculture and food security, as well as for the adaptation of key crops to the new conditions brought about by climate change, and plant pests and diseases. Moreover, when it comes to crop genetic resources, all countries are interdependent and identification of the country of origin is often difficult, given the millennia of agricultural history. In addition, genebanks all over the world now have collections of all major crops, making the search for genetic resources in situ less necessary. Finally, another crucial characteristic of PGRFA is that conservation and use are linked: conservation is performed through use, and unless an agricultural variety is used, it cannot be conserved for more than a few decades before it is eventually lost (ITPGRFA Secretariat 2012).

The objectives of the ITPGRFA are the conservation and sustainable use of PGRFA and the fair and equitable sharing of the benefits arising out of their use, in harmony with the $\mathrm{CBD}$, for sustainable agriculture and food security (ITPGRFA Art. 1). The core of the Treaty is the MLS, which facilitates access to, and exchange of, a list of 64 crops and forages considered vital for food security and agricultural research, listed in Annex I of the Treaty. Importantly, exchanges of such crops and forages should serve solely the purpose of utilization and conservation for research, breeding and training for food and agriculture and not other uses such as chemical or pharmaceutical ones. Such uses would fall under the scope of the 2010 Nagoya Protocol on ABS, adopted under the CBD. The MLS also institutionalizes the sharing of the benefits 
arising from the utilization of these resources; the Treaty regulates both monetary and non-monetary benefit-sharing (Arts 10-13). Monetary benefitsharing refers to the return to the Treaty system of a portion of the gains of commercialization of products developed on the basis of material accessed through the MLS, under conditions detailed below. Non-monetary benefitsharing, according to the Treaty provisions, involves exchange of information, access to and transfer of technology, capacity-building, as well as facilitated access to Annex I resources, which is recognized as a benefit in itself (Tsioumani 2004, 2018).

The MLS thus operates as a virtual common pool of PGRFA held by various national and international institutions. The users of such PGRFA exchange resources and assume benefit-sharing obligations. A review of academic and grey literature shows that it is among the most sophisticated ABS systems in international law (Halewood et al. 2013b; Kamau and Winter 2013; Guneratne 2012; Biber-Klemm and Cottier 2006; Chiarolla 2012; Correa 1999; Helfer 2004; Raustiala and Victor 2004; Oberthür et al. 2011; Oguamanam 2006; Cabrera Medaglia et al. 2013; Chiarolla et al. 2013; Morgera et al. 2014) and, together with the system established under the World Health Organization (WHO) Pandemic Influenza Preparedness (PIP) Framework (briefly addressed in comparison below), among the few operational ones. It includes collections of Annex I crops that are under the management and control of parties and in the public domain, those held by the CGIAR centres and other international institutions that have signed agreements with the Treaty's Governing Body, as well as those included voluntarily by other holders, such as private companies or indigenous peoples and local communities. Such voluntary contributions have been modest, with examples including certain Swiss and French associations, and association ANDES on behalf of the Potato Park in Peru (explored in the fourth chapter), which contributed the Park's collection of 1300 potato varieties, but no private company (López Noriega et al. 2013).

Exchanges of MLS material take place in accordance with the terms of the Standard Material Transfer Agreement (SMTA), which is a standardized private-law contract between a provider and recipient (user) of material, negotiated and adopted by the Treaty's Governing Body. ${ }^{6}$ While providers are usually public or international genebanks, users can be organizations, private entities or individuals. In practice, as noted below, mostly public-sector breeders use the MLS (López Noriega et al. 2013; ITPGRFA Secretariat 2015). The SMTA provides for mandatory payments by users to the Treaty's Benefit-sharing Fund according to two monetary benefit-sharing options:

(1) a default scheme, according to which a recipient that commercializes a plant product incorporating material from the MLS that is not available to others for further research and breeding (i.e. it is patented) will pay $1.1 \%$ of gross sales to the Treaty's Benefit-sharing Fund, less 30\% (to cover expenses), i.e. $0.77 \%$ (SMTA Art. 6(7) and Annex 2; Moore and Goldberg 2010); and 
(2) an alternative, whereby recipients pay $0.5 \%$ of gross sales on all products of the species they accessed from the MLS, regardless of whether the products incorporate the material accessed and regardless of whether or not the new products are available without restriction (SMTA Art. 6(11)).

Furthermore, voluntary payments are encouraged when a recipient commercializes a plant product that incorporates material from the MLS if that product is available without restriction to others for further research and breeding (SMTA Art. 6(8)).

The distribution of user-based payments accumulated through the SMTA and other funding such as country donations is operated through the Benefit-sharing Fund, established as part of the Treaty's Funding Strategy (FAO 2006). Under the direction of the Governing Body and through a project-based approach (FAO 2007), the Benefit-sharing Fund allocates the accumulated funds to particular activities designed to support farmers and breeders in adapting crops to changing needs and demands in the face of climate change, giving priority to farmers in developing countries who still conserve and manage sustainably crop diversity in their fields. Priority areas include: information exchange, technology transfer and capacity-building; management and conservation of plant genetic resources on-farm; and the sustainable use of plant genetic resources. For instance, the third project cycle, launched in 2014, consisted of 22 projects implemented in 45 developing countries from all regions, under the overall aim to build resilience in the face of climate change and food insecurity through the sustainable use, conservation, development and study of genetic diversity to the benefit of the most vulnerable communities.

As noted above, non-monetary benefit-sharing is accomplished through facilitated access, information sharing, technology transfer and capacity-building. Facilitated access enables agricultural research for global food security. Information exchange may encompass catalogues and inventories, related technologies and research results. It may concern both documentation of the resource as well as information about its potential uses. The information thus adds value to the resource exchanged through the MLS. Technology transfer may be achieved through participation in crop-based or thematic networks and partnerships, commercial joint ventures and availability of research facilities. Mechanisms for capacity-building include scientific education and training in the conservation and use of PGRFA, development of relevant facilities and joint scientific research.

Two preliminary observations can be made at this stage with regard to illuminating the concept of fair and equitable benefit-sharing. First, a lack of conceptual clarity is observed with regard to terminology. Monetary benefitsharing refers both to the accumulation of monetary benefits through the SMTA (user-based benefit-sharing) and to the distribution of monetary benefits through the Benefit-sharing Fund. This lack of clarity may lead to confusion when it comes to policy development and implementation. Second, the line between monetary and non-monetary benefit-sharing is blurred for multiple reasons, 
highlighting the close interlinkages among relevant mechanisms. For instance, while the funds distributed through the Benefit-sharing Fund are the outcome of the monetary benefit-sharing mechanism of the Treaty, the funded projects produce both improved genetic resources - which are to return to the system enriching the MLS - and non-monetary benefits, such as information, training or partnerships between farmers and breeders. In fact, as noted above, information exchange, technology transfer and capacity-building, namely three of the mechanisms of the Treaty for non-monetary benefit-sharing, are priorities for the Benefit-sharing Fund. The brief history of the Benefit-sharing Fund (launched in 2008) shows that non-monetary benefits are also being generated and shared despite the fact that parties' obligations to share non-monetary benefits are linked to other mechanisms and not to the Benefit-sharing Fund directly (Galluzzi et al. 2014). The Global Information System, for instance, is the mechanism specifically built for information exchange (ITPGRFA Arts 13(2)(a) and 17; Ker et al. 2013). The Global Information System aims to integrate and augment existing systems to create the global entry point to information and knowledge for strengthening the capacity for PGRFA conservation, management and utilization. It is still at an infant implementation stage, as the Governing Body adopted its vision and the first programme of work in 2015.

Although it is difficult to assess the exact economic value of non-monetary benefit-sharing activities, it can be argued that they serve as a precondition to monetary benefit-sharing. Non-monetary benefit-sharing mechanisms can be used to build the capacities required for facilitated access to, and use of, PGRFA, which could potentially result in the development of new varieties and product commercialization (Louafi 2013). Non-monetary benefit-sharing, in the form of information exchange, technology transfer and capacity-building, is thus instrumental in addressing the unequal capacities of countries and communities to benefit from the ITPGRFA and genetic resource use in general, and thus bridging the capacity, fairness and equity gap in agriculture and agrobiodiversity conservation.

A set of challenges have, however, arisen with regard to the ability of the MLS to generate and share monetary benefits (Frison et al. 2011). As a result, very limited user-based payments have been realized since the Treaty's entry into force, and the Benefit-sharing Fund has been operating solely on the basis of donor country voluntary contributions (ITPGRFA Secretariat 2013; Tsioumani et al. 2017). In fact, the first user-based payment realized since the Treaty's entry into force took place in June 2018, and concerned the commercialization of vegetable varieties not included in the MLS; the payment was made on the basis of national legislation, which made the use of the SMTA mandatory for all PGRFA (ITPGRFA Secretariat 2018). Therefore, while it was certainly a reason for celebration, it can safely be considered an exception to the rule. A series of studies undertaken in the ITPGRFA framework has explored obstacles to the realization of monetary benefits and confirmed that projections of benefit flows will be 'moderate at best', and will take even longer than expected (Moeller and Stannard 2013). Consequently, a working group was 
specifically mandated in 2013 to "enhance the functioning of the Multilateral System'.

The sub-sections below address legal and policy challenges related to the accumulation and distribution of monetary benefits, as well as the intergovernmental negotiations on the revision of the MLS.

\section{Accumulation of benefits}

The lengthy time period required for research, development and commercialization partly explains the failure to generate and share commercial benefits from the SMTA (ITPGRFA Secretariat 2013). There is more than that though. The first challenge regarding accumulation of benefits concerns the relationship between benefit-sharing and IPRs. As noted above, mandatory monetary benefit-sharing is linked to patenting; it serves as compensation when there is a restriction in use associated with the patenting of a PGRFA product incorporating MLS material, i.e. when the outcome of the research and development process does not return to the MLS to be made available for further research and breeding. It has been argued that this causal relationship between patenting and mandatory monetary benefit-sharing indicates that Treaty drafters designed monetary benefit-sharing as a disincentive to patenting, ${ }^{7}$ prioritizing continued unrestricted exchanges of PGRFA for research and breeding. While such restrictions are indeed incompatible with the open exchange systems needed for food security and agricultural biodiversity conservation (Louafi and Welch 2014), this illustrates a fundamental contradiction inherent in the Treaty system - monetary benefit-sharing was designed as a central tool for revenue generation to fund the ITPGRFA goals (which include fair and equitable benefit-sharing); at the same time, monetary benefit-sharing is tied to restrictions in use, which threaten the very essence of the system and its goal of food security, by impoverishing its material base (Helfer 2003; Tsioumani 2018; Frison 2018).

Three additional factors greatly impact effectiveness of the system (Frison 2018). First, coverage of the MLS is not comprehensive (e.g. soybean, sugarcane, tomato and coffee are not included). Notably, some of these crops attracted significant research effort resulting in patented material, and their inclusion could result in mandatory benefit-sharing payments. Second, as noted above, the MLS only covers public and CGIAR (and other international) collections of Annex I PGRFA. This means that most material in the MLS can also be found elsewhere, for instance, in collections of private companies or non-parties to the Treaty, and can be made available without adherence to the benefit-sharing terms of the SMTA. Third, many parties to date failed to notify the Secretariat of their PGRFA included in the MLS, thus making this material inaccessible to users due to lack of awareness. That said, ratification by the USA in March 2017 is expected to close one of the major loopholes and allow for more comprehensive coverage, once the country's vast crop collections are notified to be included in the MLS. 
On the user side, in practice most of the organizations that choose to take material from the MLS and incorporate it in new products do not restrict access to the improved material for further research and breeding purposes and are thus not obliged to share monetary benefits. Commercial users who would be more likely to trigger mandatory monetary benefit-sharing requirements have consistently chosen to access material from other sources, not the MLS (CGIAR Consortium 2015a).

\section{Distribution of benefits}

As noted above, distribution of monetary benefits is operated through the Benefit-sharing Fund via a project-based approach. According to the Treaty text (Art. 13(3)), benefits should flow primarily, directly and indirectly, to farmers.

Looking at the 22 projects funded under the third cycle, most of them are run by international and national agricultural research centres, two are run by NGOs and one is run by an association of indigenous organizations. ${ }^{8}$ Channelling benefits directly to farmers is not easy, given the limited capacities of most farmer communities and organizations to reach international funding through the complex Benefit-sharing Fund application and project execution procedures. While this project-based approach arguably combines elements of inter-state benefit-sharing regulation with implementation at the local level, its results illustrate the challenges that an international organization faces to reach directly communities on the ground, and vice versa. In addition, national partners, in particular agricultural research centres, are expected to serve as intermediaries and transmit to farmers the outcomes of the research funded, including, for instance, seeds of improved varieties, information and training or collaboration in participatory breeding programmes.

An additional challenge lies in the diversity of the ITPGRFA system users. The Treaty is to serve a wide set of users across the entire spectrum of agricultural production, with different or contradictory needs: public research institutes, smallholder farmers, companies big and small, in developing and developed countries, actors engaged in commercial or non-commercial research, in formal and informal seed systems. The current realities of agricultural research and development characterized by high market concentration as noted above put at risk not only farmers' innovation on-farm but also public agricultural research. As a result, agricultural research centres in developing countries also compete for funding under the Treaty. The Treaty struggles to find and maintain a balance between modern scientific methods of identifying and developing new varieties on the basis of material in ex situ collections and farmers' traditional agro-ecological approaches. It remains a matter for consideration though whether the current approach serves well the objectives of sustainable agriculture and global food security (Swiss Government 2015; Frison 2018). Sélim Louafi in particular has questioned whether a competitive project-based approach is appropriate to meet challenges related to distributional equity, the public value of PGRFA and the required cooperation 
among different states and actors to address food security concerns (Louafi 2013). A series of measures have been taken to address some of these concerns, including the organization of regional workshops to build capacities to access funding, and the prioritization of cooperative, multi-country projects.

\section{Negotiations for the revision of the Multilateral System}

As noted above, the realization that the MLS has not been producing monetary benefits led to the establishment of a working group with the mandate to 'enhance the functioning of the MLS', by developing measures to increase user-based payments and contributions to the Treaty's Benefit-sharing Fund (Tsioumani 2014). However, following six years of deliberations, including an immense amount of work on complex legal and policy issues, time and financial resources spent on the effort and agreement reached on several important matters, negotiations collapsed at the Governing Body session in November 2019, marking a missed opportunity, for the Treaty and for multilateralism in general (Tsioumani et al. 2019b). The section below outlines some of the highlights of the process.

Aseffa Seyoum and Eric Welch had suggested that a combination of upfront payments for access with no or low restrictions in use may be better suited to generate benefits, ensure continued exchanges and increase legal certainty (Seyoum and Welch 2013). Indeed, early in the process the Working Group started developing a subscription system for access to material in the MLS, to be included in a revised SMTA. This means that subscribed users would need to pay before access (Tsioumani 2015). Expanding the list of crops included in the MLS to add those crops that attract significant research and development efforts and potentially result in commercially successful varieties, such as soybean and tomato, was also proposed as an additional part of the solution to enhance the MLS and the flow of benefits.

The successful multilateral ABS system established under the WHO PIP Framework has also been proposed as a model with regard to attracting payments (Third World Network 2015), although one should take into account the crucial difference between the highly regulated transfers of pathogenic material made available under strict conditions from very specific providers, and the transfers of PGRFA, which can generally be made available easily from several providers and do not constitute a biosecurity risk. The WHO PIP Framework is an ABS instrument that aims to put the sharing of influenza viruses of human pandemic potential on a par with access to benefits such as vaccines. Under the PIP Framework, member states share pathogenic material through the Global Influenza Surveillance and Response System (GISRS). Transfers of material between GISRS collaborating institutions are conducted through a standard material transfer agreement which does not involve benefitsharing obligations, nor can recipients apply for IPRs over acquired material. A second type of standard material transfer agreement (SMTA2) regulates transfers of pathogenic material to recipients outside the system, in particular the 
private sector and research institutions. SMTA2 does not exclude IPRs, but involves a range of options regarding benefit-sharing activities, to be agreed upon on a case-by-case basis. Benefits are not shared on a bilateral basis between provider and recipient, but multilaterally through WHO with particular regard to the needs of developing countries. As the standard material transfer agreements are binding contracts, the agreed benefit-sharing arrangements are also binding upon the relevant parties. An additional innovative form of benefit-sharing established under the PIP Framework is the 'partnership contribution', which consists of financial contributions from vaccine, diagnostic and pharmaceutical manufacturers who use GISRS, and is equivalent to $50 \%$ of its running costs, aiming to fund influenza pandemic preparedness and response (Switzer et al. 2019).

The revision of the SMTA and the expansion of the list of crops in the MLS were seen as a package deal during the ITPGRFA negotiations. On the one hand, developing countries wishing to see benefits flowing into the system prioritized revision of the SMTA to enable the flow of monetary benefits from commercial users. On the other hand, developed countries with big seed companies and advanced research capacities have an interest in expanding the list of crops in the MLS for continued agronomical research under predictable conditions. The Working Group achieved a breakthrough in June 2019 and was successful in forging the main parts of a compromise; it reached tentative agreement on amending the list of crops in the MLS to cover all PGRFA under the management and control of parties and in the public domain that are found in ex situ conditions, allowing parties the right to make reasoned declarations exempting a limited number of native species. At the same time the Working Group made significant progress in detailing the subscription system for access to MLS crops, while also providing for 'single access' to the MLS with no subscription as an exception. Two main issues remained outstanding: the payment rates for monetary benefit-sharing, and the issue of genetic sequence data, which refers to information generated from genetic resources (Tsioumani et al. 2019a).

In June, agreement seemed to be within reach for the first time on benefitsharing payment rates. Since the subscription system would be the main approach and single access the exception, the Working Group agreed in general to set a lower rate for the primary model and a much higher rate for exceptional single access, aiming to attract more users and hopefully more funds. Uncertainty remained, however, with regard to the exact payment rate that would result in tangible benefits while attracting users into the system, as user-based income would still depend on the number of companies that would eventually subscribe.

At the Governing Body meeting in November 2019, however, negotiations collapsed amidst not only substantive disagreements but also procedural confusion. While disagreement remained over payment rates for benefit-sharing, it was the issue of benefit-sharing arising from the use of genetic sequence data that was identified as a deal-breaker (Tsioumani et al. 2019b). 


\section{Benefit-sharing in agricultural research}

The issue of genetic sequence data, or digital sequence information as it is referred to in the CBD context, has been making waves in all ABS-related fora, as its use in research and development could result in bypassing both the need for physical access to genetic resources, and requirements for benefit-sharing, potentially making ABS frameworks obsolete unless specifically addressed. The term refers to information and knowledge extracted from biological material thanks to advances in bioinformatics, an interdisciplinary field of knowledge. Developing and using a variety of methods and software tools, bioinformatics lead to the 'dematerialization' or digitalization of genetic resources. This suggests that the information content of genetic material may be extracted, processed and exchanged in its own right, detached from the physical genetic resource. The availability and easy exchange of large amounts of genetic sequence data have the potential to facilitate research on genetic resources, especially for actors in developed countries who have the capacities to analyse and use such data. At the same time, the issue challenges traditional ABS frameworks, including the Treaty, by posing two main regulatory issues: the possibility of appropriation of genetic sequence data through IPRs, and the question of commercial value arising from the use of such data, and related benefit-sharing obligations (Tsioumani et al. 2019b). The challenge is to find a way to integrate genetic sequence data in the MLS to honour benefit-sharing obligations, while at the same time maintaining the unrestricted flow of information, and building capacity to use such information to serve sustainable development needs, particularly in developing countries. States are divided largely across traditional North/South lines. Developing countries wish to ensure that benefit-sharing obligations extend to use of genetic sequence data, to make sure that the Treaty's benefit-sharing obligation is not bypassed and to maintain relevance of the framework in light of technological developments. Developed countries, on the other hand, point to legal issues and limitations regarding the Treaty's scope, arguing that the Treaty was developed to regulate exchanges of physical genetic resources.

In November 2019, ITPGRFA negotiators missed an opportunity to enhance the system of the Treaty and propose international regulations on use of genetic sequence data in response to the specific needs of the agricultural community. Arguably, the failure to conclude the revision process marked a missed opportunity for multilateralism in general, at times of rising nationalism and fading political will to address global problems through international cooperation (Tsioumani 2019). Benefit-sharing from the use of genetic sequence data (or digital sequence information) will continue to be a central topic in ABS-related fora, including the negotiations for a post-2020 global biodiversity framework under the auspices of the CBD, which will culminate at the 2020 UN Biodiversity Conference, to be held in Kunming, China.

Following failure to revise the system, exchanges of PGRFA in the MLS will continue on the basis of the current Treaty regime. These exchanges are conducted within the broader regime complex of relevance to agricultural research and development. As examined above, IPR instruments form a central 
part of this regime complex. The following section will explore the current lack of support for benefit-sharing in IPR-related instruments, and related human rights, development and ethical concerns.

\section{IPR-related instruments and benefit-sharing}

Unlike environmental treaties such as the CBD and the ITPGRFA, there is no explicit requirement related to fair and equitable benefit-sharing in IPR instruments, the argument being that IP protection benefits society as a whole by promoting innovation. This section will address: the role of exceptions under the UPOV Convention and their potential interpretation as a benefit-sharing mechanism; ongoing negotiations of relevance under the WTO and WIPO; and related human rights, development and ethical concerns. It will also explore challenges for national implementation in the context of conflicting international law obligations, illustrated by relevant examples.

\section{Exceptions to plant breeders' rights and benefit-sharing}

As noted above, the model of PBRs under UPOV 78 permitted the use of protected varieties as the source material of further breeding (breeders' exception) and the re-use of saved seeds by farmers (farmers' privilege) (Correa 1999). Both are important mechanisms to protect farmers' livelihoods, allow traditional seed-saving and exchange practices and, in general, guarantee the continued exchange of material for public research and global food security purposes (Tsioumani et al. 2016). These exceptions, however, were restricted in UPOV 91. The plant breeders' exemption was preserved, and acts done 'privately and for non-commercial purposes' or 'for experimental purposes' were also exempted (UPOV 91 Art. 15(1)). This latter exception of private acts could apply to subsistence farmers. However, the scope of protection was extended beyond the propagating material of protected varieties to include 'essentially derived varieties' (Art. 14(5)). The farmers' privilege for replanting was made optional, allowed at the discretion of UPOV member states 'within reasonable limits and subject to the safeguarding of the legitimate interests of the breeder' and only to 'permit farmers to use for propagating purposes, on their own holdings, the product of the harvest which they have obtained by planting, on their own holdings, the protected variety' (Art. 15(2)). Seed exchanges and informal sales, which are common practice in most developing countries (as explored in the second chapter) are thus not covered. This restricts exchanges among farmers (Helfer 2004; Chiarolla 2012) which facilitate crop and variety rotation (Silva Repetto and Cavalcanti 2000), to the detriment of both farmers' livelihoods and farmer-based innovation.

Despite these limitations, the UPOV Council has consistently highlighted the importance of access to genetic resources to ensure progress in plant breeding and thereby to maximize the use of genetic resources for the benefit of society, and has expressed its concern that additional benefit-sharing measures could 
introduce barriers to progress in breeding (UPOV 2003; Cabrera Medaglia 2010; Dutfield 2011). In its contribution to the CBD negotiations on access and benefit-sharing, UPOV considered the breeder's exception, an 'inherent benefitsharing principle' (UPOV 2003). The same goes for the exception to breeders' rights regarding acts done privately and for non-commercial purposes and the optional farmer's privilege.

From a fairness and equity perspective, UPOV 91 aggravates the asymmetry in protection between modern and traditional varieties, and limits the discretion of member states that wish to safeguard agricultural systems that rely upon traditional practices and smallholder farmers. In addition, the presumption that technological developments benefit society at large fails to acknowledge the well-documented fact that technologies 'such as high-yielding crop varieties, agrochemicals and mechanization have primarily benefitted the better resourced groups in society and transnational corporations, rather than the most vulnerable ones' (IAASTD 2009: 23) and ignores the question of distributing the benefits to the most vulnerable groups of society, including smallholder farmers. As extensively highlighted in literature, the UPOV model was designed with the commercialized farming systems of the developed world in mind (Commission on Intellectual Property Rights 2002) and is not appropriate for developing countries wishing to maintain small-scale farming largely depending on informal seed systems (Oguamanam 2015). Pressure to comply with UPOV 91 standards therefore creates a host of human rights, political and ethical issues, addressed further below.

\section{Benefit-sharing in patent laws: exceptions and WTO negotiations}

My examination of possible indications of benefit-sharing in the patent landscape is twofold. I first address any permitted exceptions to patent holders' rights, along the lines of exceptions to PBRs above, and I then consider a possible amendment of the TRIPS Agreement to be in line with CBD principles, including fair and equitable benefit-sharing.

Exceptions to patent holders' rights are even more limited than under UPOV 91. They can be introduced under Article 30 of the TRIPS Agreement, ${ }^{9}$ but practice varies among WTO member states and the WTO dispute settlement bodies have interpreted the provision narrowly (Yamane 2011). Viola Prifti has recently analysed the breeder's exception under TRIPS Article 30, noting that the vagueness of the provision does not allow concluding which type of research exception can be deemed permissible. Compliance of national patent legislation with Article 30 is to be decided case-by-case by a WTO panel (Prifti 2015).

Only one WTO panel has addressed the issue of interpretation of Article 30 so far, while examining an EC-Canada case focusing on Canada's generic pharmaceutical sector. ${ }^{10}$ The case involved a complaint brought by the EC against Canada alleging that provisions of Canadian patent law that allowed the stockpiling of products prior to the expiration of a patent term, and that authorized the use of patented inventions for the purposes of preparing and 
pursuing regulatory submissions prior to the expiration of a patent term, violated TRIPS obligations. The EC claimed that the relevant provisions of Canada's Patent Act allowed generic producers to obtain approval for, and stockpile, patented medicines contrary to TRIPS rules. Canada invoked Article 30 , asserting that it was providing limited exceptions to the rights of patent holders.

The Panel analysed the meaning of the three elements of Article 30: the meaning of limited exception, not unreasonably interfering with the normal exploitation of the patent, and not unreasonably prejudicing the interests of the patent holder, taking into account the legitimate interests of third parties. It determined that Canada's stockpiling exception was not sufficiently 'limited' because it potentially allowed an unlimited quantity of products to be made during the patent term. It therefore did not qualify as a limited exception under Article 30. Canada's regulatory review exception, which allows third parties to use patented inventions during the term of the patent to develop submissions for approval, was deemed limited because it addressed only a small part of the patent right, and was reasonably closely circumscribed. It was eventually found overall lawful also under the other two elements of Article 30 regarding unreasonable interference with patent exploitation and prejudice to the patent holder.

Prifti concludes that the Panel's interpretative outcome is limited and does not help with defining a priori which type of research exception is permissible under Article 30 of the TRIPS Agreement. She notes critiques that the Panel fails to take into account the particularities of domestic innovation systems and it might discourage countries from adopting flexible solutions based on their socio-economic needs (Prifti 2015).

The issue of the breeder's exception to patent rights may be revisited once the Agreement on a Unified Patent Court ${ }^{11}$ enters into force. This Agreement, which is open to EU member states, makes the breeder's exception mandatory for its parties. It includes a provision which limits the effects of patent rights for 'the use of biological material for the purpose of breeding, or discovering and developing other plant varieties' (Art. 27(c) of the Agreement on a Unified Patent Court).

In addition to the legal uncertainty with regard to the use of exceptions, the TRIPS Agreement does not require disclosure of prior informed consent of the country of origin and of benefit-sharing in patent applications involving use of PGRFA. Therefore, foreign companies may obtain private rights derived from a country's genetic resources without having to adhere to the CBD principles (Commission on Intellectual Property Rights 2002). Although it can be argued that such access to resources may not be legitimate, enforceability of CBD principles is weak unless mandated and monitored by national legislation. In addition, the validity of the patent would be assessed on the basis of the legislation of the country that granted it, not the country that provided the genetic resource used.

Unless the TRIPS Agreement is amended to ensure respect for the CBD principles, the implementation and enforceability of such principles would remain 
elusive (Chouchena-Rojas et al. 2005). Importantly, such an amendment would allow access to the WTO dispute settlement system for breaches of the CBD requirements, as, unlike the CBD, TRIPS rules are enforced through mandatory adjudication and retaliatory sanctions. On the basis of the review clause enshrined in Article 27(3)(b) of the TRIPS Agreement, as well as the 2001 Doha Declaration, which broadened the discussion to also address the relationship between the TRIPS Agreement and the CBD, several developing countries, led by India and Brazil, have thus called for an amendment to TRIPS by introducing requirements to disclose the origin of genetic material and evidence of prior informed consent and benefit-sharing in patent applications. The original proposal was supported by 110 WTO member states by 2008, when a strategic alliance was made with the EU and Switzerland calling for a procedural decision to negotiate in parallel the biodiversity amendment and geographical indications. No progress has been achieved since, despite efforts by developing countries to revive negotiations.

In the context of the WTO deliberations, Switzerland has proposed an amendment to the regulations of WIPO's Patent Cooperation Treaty so that domestic laws may ask inventors to disclose the source of genetic resources and traditional knowledge when they apply for patents. This proposal identifies WIPO as the competent forum to address disclosure of origin and evidence of prior informed consent and benefit-sharing in patent applications, although ongoing negotiations address such issues under WIPO's Intergovernmental Committee on Intellectual Property and Genetic Resources, Traditional Knowledge and Folklore (IGC), addressed below very briefly.

\section{WIPO negotiations}

As the impasse on these negotiations at the WTO continues, many countries have been calling for disclosure requirements and mechanisms, including on benefit-sharing, to be addressed under the IGC. Since 2000, the IGC has had a mandate to negotiate text-based instrument(s) for the effective protection of genetic resources, traditional knowledge and traditional cultural expressions. Negotiations have been ongoing on a parallel basis on three instruments, one for each of the subject matter areas, with the text on genetic resources considered the most advanced. Despite numerous sessions over the last 20 years, however, agreement remains elusive. Some links with environmental treaties have been made during the negotiations though, and admittedly reaching agreement could change the course in the IPR realm. As an example, according to the latest draft on genetic resources, ${ }^{12}$ the ITPGRFA MLS could be disclosed as the source of PGRFA used in patent applications. ${ }^{13}$

\section{Human rights, development and ethical concerns}

Both PBRs and patents used in agricultural research and development are widely criticized as designed to suit the needs of developed countries, ignoring different 
contexts in the developing world. They have been associated with reducing the developmental choices of developing countries, intensifying control by agrochemical companies, raising the cost of agricultural inputs and risking the food security of vulnerable groups, including smallholder farmers (Correa 1995; Dutfield 2000; Commission on Intellectual Property Rights 2002; Drahos and Braithwaite 2002; Drahos 1996).

Ample literature highlights that implementation of UPOV 91 and the TRIPS Agreement may result in contraventions to human rights (UNDP 2000; Correa and Yusuf 1998). The Sub-Commission on the Promotion and Protection of Human Rights of the former UN Commission on Human Rights declared that there are apparent conflicts between the IPR regime and international human rights law, in relation to the transfer of technology to developing countries, the consequences of plant variety rights and the patenting of genetically modified organisms for the enjoyment of the right to food, biopiracy and the reduction of communities' control over their genetic and natural resources and cultural values $^{14}$ (Weissbrodt and Schoff 2003).

Additionally, former UN Special Rapporteur on the Right to Food Olivier De Schutter criticized UPOV 91 for restricting farmers' privilege, highlighting concerns arising from the strengthening of PBRs regarding the right to food. He further pointed to obstacles in public research caused by the intensification of IPRs, and to the need for a broad interpretation of the limitations that can be imposed to the patent rights holder (De Schutter 2009). Challenging the idea that IP protection benefits society as a whole, De Schutter further argued that the human rights framework requires investigating primarily who benefits from any technological advance, with the needs of the most vulnerable groups at the centre of attention (De Schutter 2009).

Accordingly, former UN Special Rapporteur on Cultural Rights Farida Shaheed also stressed tensions between IPRs and the right to benefit from scientific progress enshrined in the Universal Declaration of Human Rights and the International Covenant on Economic, Social and Cultural Rights. She has noted that 'the need to promote everyone's access to science and its applications raises the issue of the sharing of benefits and the transfer of scientific knowledge and technologies' (Shaheed 2012: 18). Cross-referencing the provisions of several international instruments, including the ITPGRFA and other environmental agreements, she has identified, in addition to tensions with IPRs, an obligation for developed countries to 'comply with their international legal obligations through ... the development of international collaborative models of research and development for the benefit of developing countries and their populations' (Shaheed 2012: 18). Developing countries, on the other hand, should prioritize the development and dissemination of simple and inexpensive technologies that can improve the life of marginalized populations. At the same time, states should protect individuals against any harmful effects of the misuse of scientific and technological developments. All these recommendations are particularly relevant in the context of agricultural development and are useful in both elucidating the 
right to benefit from scientific progress and contextualizing the concept of fair and equitable benefit-sharing.

Legal debates on social and moral concerns continue to rage in several jurisdictions around the globe. Gene patentability in particular remains an open question in IP-related bodies, legislatures and courts (Nuffield Council on Bioethics 2002). Are DNA sequences invented or just discovered? In the USA, the Supreme Court held in Myriad ${ }^{15}$ that DNA segments and the information they encode are not patent-eligible when they have been simply isolated from surrounding genetic material. With Myriad, the US Supreme Court reversed years of prior jurisprudence and confirmed a shift in the broad scope of patentability of genetic sequences. In Europe, the position is different. The Biotechnology Directive mentioned above states that biological material that is isolated from its natural environment or produced by means of a technical process may be the subject of an invention, even if it previously occurred in nature. However, as ruled by the European Court of Justice in Monsanto Technology v. Cefetra $B V,{ }^{16}$ in order to meet the requirements for patent eligibility, the 'functionality' of the genetic sequence must be disclosed in the patent application (i.e. a DNA sequence alone, without any indication of what it does, is not a patentable invention). Developing countries have also sought to set their own standards within the international legal framework. Brazil, for instance, excludes living beings or biological materials found in nature from patentability, even if isolated, and this includes the genome or germplasm of any living being (Correa 2014).

\section{Challenges for national implementation}

The choices that national governments need to make in this complex framework of contradictory rules and objectives is illustrated by the following question on the clash between IPRs and farmers' rights: is a farmer allowed to save, exchange and re-use seed that incorporates an IPR-protected component? Can it be argued that in the context of the entire spectrum of their international legal obligations, IPR-, biodiversity- and human rights-related, national governments may opt for supporting farmers' seed rights against the interests of IPR holders, through national legislation (Tsioumani et al. 2016)?

As explored in further detail in the second chapter, national positions vary. Jurisprudence in US and Canadian courts has affirmed the primacy of patent rights over the right of the physical owner of the seed to save and replant (Monsanto Canada Inc. v. Schmeiser; Bowman v. Monsanto Co). ${ }^{17}$ India's 2001 Act on the Protection of Plant Varieties and Farmers' Rights, on the other hand, establishes rights for farmers to save, use, exchange and sell farm-saved seed, conferring also related rights to breeders and researchers (Farmers' Rights Project 2009). A member of the WTO and the TRIPS Agreement, India considered its legislation to be in compliance with TRIPS provisions on plant variety protection, and applied for UPOV membership. The Act, however, was found not in compliance with the UPOV requirements and now, more than 
ten years later, India's UPOV application is still pending (Farmers' Rights Project 2009; UPOV 2019).

While many developing countries, particularly in Africa, have resisted ratifying UPOV 91 or adopting it as the standard for their plant variety protection laws, as noted above, pressure continues as a result of bilateral and regional trade and investment agreements, and technical advice, including from UPOV and WIPO. The African Union's African Model Legislation on the Protection of the Rights of Local Communities, Farmers and Breeders, ${ }^{18}$ for instance, which attempted to strike a balance between the commercial interests of breeders, food security and cultural and social objectives, was heavily criticized by UPOV and WIPO, as inadequate protection of the commercial interests of breeders and a violation of the TRIPS Agreement (Isiko Štrba 2017).

Among an increasing amount of literature, both Susan Isiko Štrba and Chidi Oguamanam have offered to-the-point, policy-relevant academic analyses of pressure exerted to developing countries to adopt UPOV 91 or TRIPS-plus standards for plant variety protection. Isiko Štrba has documented the pressure to African countries through technical advice, including through African regional organizations on intellectual property (Isiko Štrba 2017). Oguamanam has explored Africa's reversal of policy position on PBRs through concerted sites of pressure, especially free-trade and economic partnership agreements, resulting in policies with a narrow focus on breeders and marginal reference to farmers, advocating the continued relevance of the African Model Legislation, mentioned above (Oguamanam 2015).

\section{Case study: benefit-sharing and patent protection - IRRI and the SPIKE gene}

To illustrate the complexities of the relationship between patent protection and fair and equitable benefit-sharing - at least in its monetary dimension - I have explored a very specific case study: the patent applications submitted by the International Rice Research Institute (IRRI) on breeding methods associated with a rice gene called SPIKE, isolated in an Indonesian farmers' variety. Civil society brought it to the attention of the ITPGRFA Governing Body, which discussed it briefly without taking any specific decision. This case study serves to illuminate the requirements for monetary benefit-sharing under the Treaty, while at the same time it provides the opportunity to assess application of the policy of the CGIAR Consortium on IPRs, as well as discuss ethical concerns around gene patentability. ${ }^{19}$

\section{The background}

IRRI is a non-profit research organization that belongs to the CGIAR Consortium, which, as noted above, is the network at the forefront of international efforts to conserve agricultural biodiversity ex situ (in its genebanks) 


\section{Benefit-sharing in agricultural research}

and to support public agricultural research. On its webpage, IRRI presents itself as 'the world's premier research organization dedicated to reducing poverty and hunger through rice science; improving the health and welfare of rice farmers and consumers; and protecting the rice-growing environment for future generations'.

Like all CGIAR centres, IRRI is bound by two sets of rules: CGIAR's internal regulations and principles, and the ITPGRFA provisions, detailed in the agreement signed with the Treaty's Governing Body under ITPGRFA Article 15 (IRRI 2006). These two sets of rules are briefly explored below.

In addition, IRRI is bound by the Consortium's policies and guidelines on open access and open data and intellectual asset management. In principle, as stated in Article 1 of the CGIAR Principles on the Management of Intellectual Assets:

CGIAR regards the results of its research and development activities as international public goods and is committed to their widespread diffusion and use to achieve the maximum possible access, scale, scope of impact and sharing of benefits to advantage the poor, especially farmers in developing countries. $^{20}$

CGIAR centres are therefore mandated to produce public goods of particular value to the developing (as well as the developed) world: conservation of agricultural germplasm (i.e. seeds or other propagating material), development of sustainable production techniques, improvement of germplasm through plant breeding and enhancement of research efforts in general (Halewood 2013). Yet the use of IP rights is not completely ruled out. The Principles also state that the 'CGIAR is committed to the prudent and strategic use of IP Rights' (Article 6(4); emphasis added). In addition, in accordance to Article 6(4),

The Centers shall carefully consider whether to register/apply for (or allow third parties to register/apply for) patents and/or plant variety protection ('IP Applications') over the Centers' respective Intellectual Assets. As a general principle, such IP Applications shall not be made unless they are necessary for the further improvement of such Intellectual Assets or to enhance the scale or scope of impact on target beneficiaries, in furtherance of the CGIAR Vision.

IP-related controversies are not unheard of in the CGIAR system. As noted in the section on the evolution of governance of PGRFA, IP controversies can be argued to be key determinants of the current legal status of the CGIAR collections.

Currently, the majority of the material positively identified as belonging to the Treaty's MLS is hosted by the CGIAR centres. In line with their agreements with the Governing Body, the centres use the SMTA when distributing Annex I 
materials, as well as materials not included in Annex I collected before the Treaty's entry into force (FAO 2007).

On IP rights, the ITPGRFA states in its Article 12(3)(d) that:

Recipients shall not claim any intellectual property or other rights that limit the facilitated access to the plant genetic resources for food and agriculture, or their genetic parts or components, in the form received from the Multilateral System.

This cryptic provision, which was notoriously difficult to negotiate (Helfer 2003), is also reflected in Article 6(2) of the SMTA. Both these provisions, as well as the CGIAR principles on IP management, raise a range of questions for the IRRI SPIKE gene case.

\section{What is the case about?}

In 2013, IRRI and Japanese researchers identified a rice gene that, in preliminary testing, increased production by $13-36 \%$ in modern long-grain indica rice varieties - the world's most widely grown types of rice (Fujita et al. 2013). The gene, SPIKE, was isolated in an Indonesian farmers' variety that is held in trust in the IRRI's genebanks and is therefore part of the Treaty's MLS.

The following year, IRRI and Japan's international agricultural research agency (JIRCAS) filed an international patent application, ${ }^{21}$ as well as several national patents, on breeding methods associated with the yield-boosting rice gene SPIKE. The applications did not escape the attention of CGIAR governance bodies; IRRI is obliged to report patent and plant variety rights applications to the Fund Council Intellectual Property Group, which monitors the application of the CGIAR Principles on the Management of Intellectual Assets.

\section{The response from CGIAR}

The CGIAR's internal deliberations are described in their 2015 Intellectual Assets (IA) report (CGIAR Consortium 2015b). According to the report, no other centre but IRRI filed plant variety protection rights or patent applications in 2015. IRRI reported filing three provisional patent applications - two in the USA and one in Australia - as well as a Patent Cooperation Treaty (PCT) filing, advancing to national phase filings in seven countries (Brazil, China, India, the Philippines, Thailand, the USA and Vietnam). All these were patent applications associated with the SPIKE gene.

IRRI claimed that the method in question has the potential to increase yield for rice varieties, but that additional research needs to be conducted in various genetic backgrounds and in different agro-climatic conditions. As it did not have the resources to perform this additional research, IRRI argued, its IP protection strategy aimed to provide an incentive for seed companies to enter into license 


\section{Benefit-sharing in agricultural research}

agreements in order to use the asset and develop new rice varieties. IRRI also claimed that the original material was acquired under the Treaty's SMTA, and that it will manage the asset in a way that does not impair legitimate use of landrace material containing the trait. In other words, it will not limit any use of the original material containing the potentially soon-to-be-patented trait by plant breeders and farmers, in accordance with the terms of the SMTA under the ITPGRFA.

The CGIAR Consortium and the Fund Council Intellectual Property Group found IRRI's justifications acceptable. Stressing that the case represents a first for the CGIAR framework, they specified the kind of information necessary to assess the acceptability of patent applications against the criteria of prudent and strategic IP use, including information on ownership, arrangements with third parties and licensing strategy. In particular, they noted that:

These national filings provided the first opportunity for the CGIAR Consortium and FC IP Group to assess, in the context of a specific scenario, the information that should reasonably be included in a Center's justifications provided in support of non-preliminary patent applications, in countries that are of strategic interest when considering CGIAR's target beneficiaries. The CGIAR Consortium and FC IP Group further clarified to Centers that justifications in such instances should contain clear information concerning ownership, arrangements with donors, co-developers or third parties for managing dissemination, specific details regarding the anticipated licensing strategy for maximizing impact, and plans for communications and impact evaluation.

(CGIAR Consortium 2015b: 3; emphasis added)

They further added that the centres should develop a clear communications strategy for any technology where reputational concerns can be reasonably anticipated, and conduct a critical evaluation of dissemination strategies for maximizing global access by farmers, as well as the manner in which patent protection will affect such access.

In an independent section of the IA report, the Fund Council Intellectual Property Group raised a number of additional concerns and recommended specific action. Pointing to the need to respect farmers' seed rights, it stressed that:

any issued patent must not limit farmers in any way from using, saving, exchanging, trading, selecting and breeding with their landraces or farmer varieties containing the SPIKE trait.

(CGIAR Consortium 2015b: 23)

It also noted that IRRI is bound by the benefit-sharing conditions of the Treaty's SMTA, and drew attention to the 'sensitivities surrounding the patenting of (methods relating to) native traits'. Finally, it recommended that 'IRRI make 
every effort to increase the scope of impact of the technology and access by farmers in developing countries, and to be transparent about its IP management practices in this regard' (CGIAR Consortium 2015b: 23).

At the end of the day, application in practice will depend on the IP management agreement signed with patent co-owner JIRCAS. The Fund Council Intellectual Property Group noted that the terms included in the agreement 'may strengthen dissemination pathways of the technology to reach target beneficiaries and preserve ample latitude for IRRI to advance the CGIAR vision and strategy' of providing broad access to IRRI's resources. It thus requested ongoing review and monitoring of IRRI's negotiations with JIRCAS to ensure that the final agreement advances the CGIAR vision. In sum, it strongly encouraged IRRI to:

- $\quad$ share its final agreement with JIRCAS with the Consortium upon execution, along with any future licensing agreements concerning the patented method;

- promote and track the scope of impacts from technology- and benefitsharing for the poor, especially farmers in developing countries; and

- pursue a transparent and proactive public communications strategy with respect to its IP management in this regard.

The response of the ITPGRFA Governing Body: spelling out the questions - and a roadmap to answers

Civil society, based on research by Edward Hammond (2017), brought the case to the attention of the ITPGRFA Governing Body. Without fully clarifying the facts of the case, they highlighted the ethical dimensions around the patenting of digital sequence information, and called for full disclosure of patent applications and IP policy changes by the CGIAR Consortium. Many participants, and those from civil society and farmer representatives in particular, argued that a patent application by a CGIAR centre on a trait found in a farmers' variety was 'shocking', while even government representatives agreed that 'it does not look good', pointing to reputational concerns.

The IRRI representative highlighted two points: according to the terms of the SMTA, the commercial exploitation of varieties comprising the protected trait would lead to monetary benefits accruing to the MLS; and access via the MLS and the provision of improved seed to farmers would not be affected.

As noted above, under the current SMTA mandatory monetary benefits flow into the system, and are then distributed through the Benefit-sharing Fund, only where the use of commercialized varieties developed on the basis of material from the MLS is restricted for further research and breeding. This means that the current system only envisages mandatory monetary benefit-sharing for patented varieties, as only patents restrict the use of protected material for further research and breeding.

From a legal point of view, therefore, the first IRRI argument on monetary benefit-sharing is accurate. As a first in the Treaty framework, the case provided 
a real-life illustration of the links between monetary benefit-sharing and patenting, and the frictions that may arise. Of course, much depends on the drafting of the final IP management agreement between IRRI and the patent coowner JIRCAS, and the licensing strategy to be used. But so long as the licensing agreements signed between the patent holders and patent users respect the benefit-sharing terms of the SMTA, IRRI seems to be in compliance. The licensing agreements should also accommodate IRRI's commitment to continue making available seed that contains the protected trait to farmers, and ensure the respect of CGIAR objectives on achieving maximum possible access, impact and sharing of benefits to advantage the poor, as well as farmers' rights.

Another question regards transparency: while patent ownership is usually a matter of public record, patent licensing agreements generally are not (Tsioumani et al. 2016). Transparency was addressed in the IRRI case; IRRI is required to report on its licensing agreements to the CGIAR Fund Council Intellectual Property Group, as well as to the ITPGRFA Governing Body, as noted above.

Still, the case is illustrative of the fundamental contradiction inherent in the Treaty system described in detail in the relevant section above: monetary benefit-sharing is tied to restrictions in use associated with patenting. This threatens the very essence of the system and its goal of food security by impoverishing its material base, the MLS. At the same time, monetary benefitsharing was designed as a central tool for revenue generation, not only to serve the Treaty's objective of fair and equitable benefit-sharing, but also to fund the overall goals of sustainable agriculture and food security.

The Governing Body did not adopt any specific decision on the IRRI patents case. It did note, however, that the CGIAR Principles on the Management of Intellectual Assets explicitly require the centres to comply with their obligations under the Treaty framework, and serve as a mechanism for monitoring and compliance. It also invited the CGIAR system to provide annual reports on the implementation of the CGIAR Principles on the Management of Intellectual Assets related to germplasm managed by CGIAR centres within the Treaty framework, 'including in cases where such germplasm, parts thereof, or information generated from the use of this germplasm are the subject matter of patent or plant variety protection applications, or are included in partnerships that qualify as restricted use or limited exclusivity agreements pursuant to the CGIAR Principles' (Resolution 4/2017). The Governing Body thus called for transparency, and arguably hinted that, at least for the time being, compliance with the Treaty framework should be assessed by the CGIAR's own system in accordance with its own principles.

The case is illustrative of a series of fundamental questions. How compatible are the restrictions in use required for monetary benefit-sharing with the open-exchange systems necessary for food security and agricultural biodiversity conservation? To what degree can the sharing ethos re-introduced by the Treaty co-exist with the highly proprietary environment of commercial plant breeding usually associated with patents? In an era of unprecedented 
patent expansion and market concentration in the agricultural sector, as well as increasing funding constraints for public agricultural research, what steps should a CGIAR centre - a centre committed to research and development as international public goods - take to fund its future research? Is it ethical, or even sustainable, for a research centre mandated to produce global public goods to seek to fund its research through patents? The CGIAR instruments call for the prudent and strategic use of IP; applications should not be made unless they are necessary for the further improvement of intellectual assets or to enhance impacts for target beneficiaries. Can the patenting of a gene found in a farmers' variety be considered in principle prudent and strategic, given the continuing debates on gene patenting? Were these patent applications really necessary to attract funding for future research? That is, did IRRI exhaust all alternatives before resorting to this costly and time-consuming process? These questions remain open.

The patenting of isolated genes has been at the heart of debate since the Treaty negotiations. Indeed, these debates are the reason behind the cryptic formulation of Article 12(3)(d). As Laurence Helfer (2003: 34-35) puts it:

The critical issue for interpreting Article 12(3)(d) is just how far a seed's genetic blueprint must be modified before the resulting genetic material is no longer 'in the form' received from the multilateral system. Most observers agree that a new plant variety or extracted genes as incorporated into such a variety would be sufficiently distinct to qualify for IPR protection. A more contentious question is whether merely extracting a gene from a seed is in itself a sufficient alteration of genetic material.

The IRRI case shows that the discussion on the patent eligibility of genetic sequences, and what the potential granting of such patents would mean for the Treaty framework, remains open. Decoupling monetary benefit-sharing from patenting was under discussion in the ongoing review process. It would be a step towards resolving the system's contradictions and simplifying access and benefit-sharing altogether, but the process has failed and stopped, at least for the time being. Clarifying whether gene patents on material acquired from the MLS are allowed could also help with implementation given the ambiguities in the Treaty text. Deliberations on genetic sequence data or digital sequence information also provide room for these discussions.

\section{Postscriptum}

The 2016 CGIAR Intellectual Assets Management Report provided an update on the IRRI case (CGIAR Consortium 2016). At the end of 2017, IRRI had signed an IP management agreement with JIRCAS, decided to pursue the SPIKE gene patent application in Japan, India, the Philippines and the USA only, and signed several non-exclusive R\&D licensing agreements with third parties. The System Council Intellectual Property Group (previously the Fund 
Council Intellectual Property Group) reached the following conclusions and recommendations.

The SC IP Group is pleased to confirm that the terms of IRRI's IP Management Agreement with JIRCAS protect dissemination pathways of the technology to reach target beneficiaries and preserve ample latitude for IRRI to advance the CGIAR vision and strategy of providing broad access to IRRI's intellectual assets. The SC IP Group regrets that IRRI, despite the recommendations given in the 2015 IA report, did not pursue a pro-active communication strategy regarding this patent given the sensitivities surrounding the protection of a method related to a 'native trait.' The SC IP Group continues to insist that IRRI provide more public information on how this patent will further the CGIAR vision, and to share with the System Office and SC IP Group a more detailed dissemination plan and/or global access strategy.

(CGIAR Consortium 2016: 15)

With no final answers on the use of the patent, the discussion outlined above remains valid.

\section{Concluding remarks}

In this chapter, I have tracked and analysed the emergence of the concept of fair and equitable benefit-sharing in the context of the evolving principles of governance of agricultural biodiversity. I argue that the first wave of privatization of genetic resources resulted in a major asymmetry between the stewards of these resources, namely biodiversity-rich developing countries and their indigenous peoples and farmer communities, and those who benefitted more from their use, predominantly private companies and more affluent groups in developed countries. Concerns regarding such unfairness were exacerbated by well-documented cases of biopiracy, where patents were sought or granted over genetic resources in the form found in nature or in farmers' fields, without further improvement. In this context of enclosure to the previous systems of exchange, and following the failed attempt to apply the common heritage approach to plant genetic resources via the International Undertaking on Plant Genetic Resources for Food and Agriculture, the principle of national sovereignty over natural and genetic resources as reaffirmed in the CBD aimed to defend the rights of countries providing such resources by creating a second, defensive enclosure. Aiming to ensure some portion of the benefits arising from the use of their resources, developing countries pushed for a major shift in the regulation of access to such resources. Thus, the CBD, a legally binding treaty, recognizes that the authority to determine access to genetic resources rests with national governments and is subject to national legislation, and includes prominently among its objectives the fair and equitable sharing of the benefits arising from their commercial or other utilization. Benefit-sharing is thus linked to the 
principle of national sovereignty, and appears to have a balancing function against the privatization of genetic resources via IPRs. Benefit-sharing can be further conceptualized as a development tool, to reap part of the gains of the biodiversity market, as well as an incentive for stewards of biodiversity, including biodiversity-rich developing countries, indigenous peoples and smallholder farmers, to reward them and enable their continued contribution to the conservation and sustainable use of biodiversity, including genetic resources.

While adoption of the CBD was considered a major victory for the global South, a second wave of privatization meant that many of the gains associated with the CBD were at risk. Illustrating a dramatic change of the legal, political and economic landscape, this wave was marked by adoption of the TRIPS Agreement, strengthening of plant breeders' rights, a continuous expansion of the patentable subject matter in view of the breakthrough of modern biotechnologies, high corporate concentration in the agrochemical sector and bilateral and multilateral pressures to developing countries to ratify IPR-related provisions in trade and investment treaties that often exceed the TRIPS standards. In this complex and often contradictory policy context, I explored the status and applications of fair and equitable benefit-sharing in environmental and IPR-related instruments governing agricultural research and development. While fair and equitable benefit-sharing is an objective of environmental treaties and the focus of sophisticated regulation efforts, the concept is not enshrined in the IPR instruments.

The ITPGRFA, negotiated in response to the CBD and developed to address the specificities of agricultural biodiversity, established the MLS of access and benefit-sharing. The MLS facilitates access to, and exchange of, a list of 64 crops and forages considered vital for food security and agricultural research, listed in Annex I of the Treaty. It also institutionalizes the sharing of the benefits arising from the utilization of these resources, including monetary and non-monetary benefit-sharing. Monetary benefit-sharing refers to the return to the Treaty system of a portion of the gains of commercialization of products developed on the basis of material accessed through the MLS. Non-monetary benefit-sharing, according to the Treaty provisions, involves exchange of information, access to and transfer of technology, capacity-building, as well as facilitated access to Annex I resources, which is recognized as a benefit in itself.

The MLS operates as a virtual common pool of PGRFA held by various national and international institutions. It includes collections of Annex I crops that are under the management and control of parties to the Treaty and in the public domain, those held by the CGIAR centres and other institutions that have signed agreements with the Treaty's Governing Body, as well as those included voluntarily by other holders, such as private companies or indigenous peoples and local communities. Exchanges take place in accordance with the terms of the SMTA, which is a standardized private-law contract between a provider and recipient (user) of material, negotiated and adopted by the Treaty's Governing 
Body. The SMTA provides for mandatory payments mainly when a user commercializes a plant product incorporating material from the MLS that is not available to others for further research and breeding (i.e. it is patented). The distribution of user-based payments accumulated through the SMTA and other funding such as country donations is operated through the Treaty's Benefitsharing Fund. Under the direction of the Governing Body and through a projectbased approach, the Benefit-sharing Fund allocates the accumulated funds to particular activities designed to support farmers and breeders in adapting crops to changing needs and demands in the face of climate change, giving priority to farmers in developing countries who still conserve and manage sustainably crop diversity in their fields.

Two observations can be made with regard to illuminating the concept of fair and equitable benefit-sharing. First, a lack of conceptual clarity is observed with regard to terminology. Monetary benefit-sharing refers both to the accumulation of monetary benefits through the SMTA and to the distribution of monetary benefits through the Benefit-sharing Fund. Second, the line between monetary and non-monetary benefit-sharing is blurred, highlighting the close interlinkages among relevant mechanisms. Such interlinkages are both operative and substantive. For instance, while the funds distributed through the Benefit-sharing Fund are the outcome of the monetary benefit-sharing mechanism of the Treaty, the funded projects produce both improved genetic resources - which are to return to the system enriching the MLS - and non-monetary benefits, such as information, training or partnerships between farmers and breeders. In fact, as noted above, information exchange, technology transfer and capacity-building, namely three of the mechanisms of the Treaty for non-monetary benefit-sharing, are priorities for the Benefit-sharing Fund. In addition, it can be argued that nonmonetary benefit-sharing mechanisms serve as a precondition to monetary benefit-sharing. Non-monetary benefit-sharing mechanisms can be used to build the capacities required for facilitated access to, and use of, PGRFA, which could potentially result in the development of new varieties and product commercialization. Information exchange, technology transfer and capacitybuilding are instrumental in addressing the unequal capacities of countries and communities to benefit from the ITPGRFA, and thus bridging the capacity, fairness and equity gap in agriculture and agrobiodiversity conservation.

A set of challenges have, however, arisen with regard to the ability of the MLS to generate and share monetary benefits. As a result, very limited userbased payments have been realized since the Treaty's entry into force, and the Benefit-sharing Fund has been operating solely on the basis of donor country voluntary contributions. Consequently, a working group was specifically mandated in 2013 to 'enhance the functioning of the Multilateral System'. However, following six years of deliberations, including an immense amount of work on complex legal and policy issues, time and financial resources spent on the effort, and tentative agreement reached on several important matters, including expanding the list of crops in the MLS and devising a system for access to MLS crops mainly upon subscription, negotiations collapsed at the 
Governing Body session in November 2019. This failure marked a missed opportunity for the Treaty, sustainable agriculture and multilateralism in general. For the time being, benefit-sharing will continue under the Treaty as originally established.

Despite the shortcomings, I argue that the objective of fair and equitable benefit-sharing introduces both legally binding obligations for the parties of these treaties, and a sharing ethos in international environmental law. This ethos may have the potential to eventually change the paradigm, affecting the acceptability and legitimacy of policy action beyond strict legal frameworks.

To be fair, the MLS is already a success in many ways. It has been facilitating hundreds of thousands of exchanges of PGRFA every year, mainly to enable public agricultural research; it has further provided valuable support, particularly through non-monetary benefit-sharing to build the capacities required for facilitated access to, and use of, PGRFA. It is thus instrumental in building endogenously defined needs and capacities of countries and communities, and bridging the fairness and equity gap in agricultural research and development. These successes, however, have been overshadowed by expectations for monetary benefits, in the context of growing inequities due to trade and IPRrelated policies.

In the IPR realm, there is no explicit requirement related to fair and equitable benefit-sharing, the main argument being that IP protection benefits society as a whole by promoting innovation. The 1978 version of the UPOV Convention permitted the use of protected varieties as the source material of further breeding (breeders' exception) and the re-use of saved seeds by farmers (farmers' privilege) - two mechanisms which could be considered as expressions of benefit-sharing. These exceptions, however, were restricted in the 1991 version of UPOV. Exceptions to patent holders' rights are usually even more limited than under UPOV 91.

From a fairness and equity perspective, UPOV 91 and the expansion of patents aggravate the asymmetry in protection between modern and traditional varieties, stifle public agricultural research and limit the discretion of member states that wish to safeguard agricultural systems that rely upon small-scale farming. In addition, the presumption that technological developments benefit society at large fails to acknowledge the well-documented fact that technologies promoting agricultural industrialization and intensification have primarily benefitted transnational corporations and ignores the question of distributing the benefits to the most vulnerable groups of society, including smallholder farmers. Both plant breeders' rights and patents used in agricultural research and development have been associated with reducing the developmental choices of developing countries, intensifying control by agrochemical companies, raising the cost of agricultural inputs, and risking the food security of vulnerable groups, including smallholder farmers.

Pressure to comply with UPOV 91 standards, including through free-trade and investment agreements, creates a host of human rights, political and ethical issues. These have been highlighted on numerous occasions, including by the 
Sub-Commission on the Promotion and Protection of Human Rights of the former UN Commission on Human Rights, and former UN Special Rapporteur on the Right to Food Olivier De Schutter, who challenged the idea that IP protection benefits society as a whole, and argued that the human rights framework requires investigating primarily who benefits from any technological advance, with the needs of the most vulnerable groups at the centre of attention. Accordingly, former UN Special Rapporteur on Cultural Rights Farida Shaheed also stressed tensions between IPRs and the right to benefit from scientific progress enshrined in the Universal Declaration of Human Rights and the International Covenant on Economic, Social and Cultural Rights. She argued in particular that developed countries should comply with their international legal obligations through the development of international collaborative models of research and development for the benefit of developing countries and their populations, while developing countries should prioritize the development and dissemination of simple and inexpensive technologies that can improve the life of marginalized populations. At the same time, gene patentability remains an open question in several jurisdictions and positions differ around the globe.

Finally, as an illustration of the complexities of the relationship between patent protection and fair and equitable benefit-sharing - at least in its monetary dimension - I have explored a very specific case study: the patent applications submitted by the International Rice Research Institute (IRRI) on breeding methods associated with a rice gene called SPIKE, isolated in an Indonesian farmers' variety. The case is illustrative of a series of fundamental questions. How compatible are the restrictions in use required for monetary benefitsharing with the open-exchange systems necessary for food security and agricultural biodiversity conservation? To what degree can the sharing ethos re-introduced by the Treaty co-exist with the highly proprietary environment of commercial plant breeding usually associated with patents? In an era of unprecedented patent expansion and market concentration in the agricultural sector, as well as increasing funding constraints for public agricultural research, what steps should a CGIAR centre - a centre committed to research and development as international public goods - take to fund its future research? Is it ethical, or even sustainable, for a research centre mandated to produce global public goods to seek to fund its research through patents? These questions remain open.

\section{Notes}

1 Diamond v. Chakrabarty, 447 US 303 (1980), ruling on the patentability of a live organism.

2 Biopiracy, a term originally coined by civil society organization the ETC Group, refers to the appropriation of the knowledge and genetic resources of farming and indigenous communities by individuals or institutions that seek exclusive monopoly control (patents or other forms of IP) over these resources and knowledge.

3 Canada, France, Germany, Japan, New Zealand, Switzerland, the UK and the USA.

4 Directive 98/44/EC of the European Parliament and of the Council of 6 July 1998 on the Legal Protection of Biotechnological Inventions, OJ L 213, (30 July 1998): 13-21. 
51992 Nairobi Final Act of the Conference for the Adoption of the Agreed Text of the Convention on Biological Diversity, Resolution 3.

6 ITPGRFA Governing Body Resolution 2/2006 (2006).

7 I am grateful to former ITPGRFA Secretary Shakeel Bhatti for drawing my attention to this point.

8 The list of approved projects is available at: www.fao.org/plant-treaty/areas-of-work/ benefit-sharing-fund/projects-funded/bsf-third-cycle/en/ (last accessed 1.11.2019).

9 TRIPS Agreement Article 30 on Exceptions to Rights Conferred reads: 'Members may provide limited exceptions to the exclusive rights conferred by a patent, provided that such exceptions do not unreasonably conflict with a normal exploitation of the patent and do not unreasonably prejudice the legitimate interests of the patent owner, taking account of the legitimate interests of third parties' (emphasis added).

10 Canada - Patent Protection of Pharmaceutical Products, WT/DS114 (17 March 2000).

11 Agreement on a Unified Patent Court, OJ C 175 (20 June 2013): 1-40.

12 'Consolidated Document Relating to Intellectual Property and Genetic Resources', WIPO/GRTKF/IC/40/6 (9 April 2019).

13 I am grateful to Claudio Chiarolla for drawing my attention to this point.

14 Sub-Commission on the Promotion and Protection of Human Rights Resolution 2000/7, UN Doc E/CN.4/Sub.2/2000/7.

15 Association for Molecular Pathology v. Myriad Genetics, Inc., 569 US 576 (2013).

16 Case C-428/08 (2010).

17 Monsanto Canada Inc. v. Schmeiser (2004) 1 SCR 902, SCC 34; Bowman v. Monsanto Co. (2013) 133 S Ct 1761.

18 Organization of African Unity (OAU), the African Model Legislation on the Protection of the Rights of Local Communities, Farmers and Breeders, and for the Regulation of Access to Biological Resources (2000).

19 The case study draws from my post on the BeneLex blog, available at: https:// benelexblog.wordpress.com/2018/05/22/irri-and-the-spike-gene/ (last accessed 10.10. 2019). It is based on personal observations as a writer for IISD Reporting Services at the seventh meeting of the ITPGRFA Governing Body, interviews with participants, as well as additional research.

20 CGIAR Principles on the Management of Intellectual Assets of 7 March 2012, endorsed by the System Council on 12 July 2016 and by the System Management Board on 13 July 2016; available at: www.cgiar.org/wp/wp-content/uploads/2018/03/ CGIAR-IA-Principles.pdf (last accessed 8.11.2019).

21 International application no. PCT/IB2014/000607, available at: https://patentscope. wipo.int/search/en/detail.jsf?docId=WO2014118636 (last accessed 8.11.2019).

\section{References}

Aoki, K. (1998) 'Neocolonialism, Anticommons Property, and Biopiracy in the (Not-soBrave) New World Order of International Intellectual Property Protection', Indiana Journal of Global Legal Studies, 6(1): 11-58.

Aoki, K. (2009) “"Free Seeds, not Free Beer”: Participatory Plant Breeding, Open Source Seeds, and Acknowledging User Innovation in Agriculture', Fordham Law Review, 77(5): 2275-2310.

Batta Bjørnstad, S.-I. (2004) A Breakthrough for 'the South'?: An Analysis of the Recognition of Farmers' Rights in the International Treaty on Plant Genetic Resources for Food and Agriculture, FNI Report 13/2004. Lysaker: Fridtjof Nansen Institute.

Biber-Klemm, S. and Cottier, I. (eds) (2006) Rights to Plant Genetic Resources and Traditional Knowledge: Basic Issues and Perspectives. Wallingford: CABI. 
Bonny, S. (2017) 'Corporate Concentration and Technological Change in the Global Seed Industry', Sustainability, 9: 1632.

Brennan, H. and Kilic, B. (2015) 'Freeing Trade at the Expense of Local Crop Markets? A Look at the Trans-Pacific Partnership's New Plant-Related Intellectual Property Rights from a Human Rights Perspective', Harvard Human Rights Journal Online, April 2015: 1-8.

Brunnée, J. (2008) 'Common Areas, Common Heritage, and Common Concern', in D. Bodansky, J. Brunnée and E. Hey (eds), The Oxford Handbook of International Environmental Law. Oxford: Oxford University Press.

Byerlee, D. and Dubin, H. D. (2009) 'Crop Improvement in the CGIAR as a Global Success Story of Open Access and International Collaboration', International Journal of the Commons, 4(1): 452-480.

Cabrera Medaglia, J. (2010) 'The Relationship between the Access and Benefit Sharing International Regime and other International Instruments: the World Trade Organization and the International Union for the Protection of New Varieties of Plants', Sustainable Development Law and Policy, 10(3): 24-53.

Cabrera Medaglia, J., Tvedt, M. W., Frederic Perron-Welch, F., Jørem, A. and Phillips, F.-K. (2013) The Interface between the Nagoya Protocol on ABS and the ITPGRFA at the International Level, FNI Report 1/2013. Lysaker: Fridtjof Nansen Institute.

Carolan, M. S. (2010) 'The Mutability of Biotechnology Patents', Theory, Culture and Society, (27)1: 110-129.

Chiarolla, C. (2012) Intellectual Property, Agriculture and Global Food Security: The Privatization of Crop Diversity. Cheltenham: Edward Elgar.

Chiarolla, C., Louafi, S. and Schloen, M. (2013) 'An Analysis of the Relationship between the Nagoya Protocol and Instruments Related to Genetic Resources for Food and Agriculture and Farmers' Rights', in E. Morgera, M. Buck and E. Tsioumani (eds), The 2010 Nagoya Protocol on Access and Benefit-Sharing in Perspective: Implications for International Law and Implementation Challenges. Leiden; Boston, MA: M. Nijhoff.

Chouchena-Rojas, M., Muller, M. R., Vivas, D. and Winkler, S. (2005) Disclosure Requirements: Ensuring Mutual Supportiveness between the WTO TRIPS Agreement and the CBD. Gland; Cambridge; Geneva: IUCN.

CGIAR Consortium (2015a) Comments from the CGIAR Consortium and its 11 CGIAR Centers Hosting International 'In trust' Crop and Forage Collections (CGIAR) on Options Considered by the Ad hoc Open-ended Working Group to Enhance the Functioning of the Multilateral System of Access and Benefit-Sharing, CGIAR submission to the 3rd Session of the WG-EFMLS, 13 May 2015.

CGIAR Consortium (2015b) CGIAR Intellectual Assets Management Report 2015. Montpellier: CGIAR Consortium.

CGIAR Consortium (2016) CGIAR Intellectual Assets Management Report 2016. Montpellier: CGIAR Consortium.

Commission on Intellectual Property Rights (2002) Integrating Intellectual Property Rights and Development Policy, Report of the Commission on Intellectual Property Rights. London: Commission on Intellectual Property Rights.

Cooper, D., Engels, J. and Frison, E. (1994) A Multilateral System for Plant Genetic Resources: Imperatives, Achievements and Challenges, Issues in Genetic Resources No. 2. Rome: International Plant Genetic Resources Institute.

Correa, C. (1995) 'Sovereign and Property Rights over Plant Genetic Resources', Agriculture and Human Values, 12(4): 58-79. 
Correa, C. (1999) Access to Plant Genetic Resources and Intellectual Property Rights, Background study paper no. 8. Rome: FAO.

Correa, C. (2009) Negotiation of a Free Trade Agreement European Union-India: Will India Accept TRIPS-Plus Protection? Berlin: Oxfam Deutschland.

Correa, C. (2014) Patent Protection for Plants: Legal Options for Developing Countries, South Centre Research Paper 55. Geneva: South Centre.

Correa, C. and Yusuf, A. (eds) (1998) Intellectual Property and International Trade: The TRIPS Agreement (1st edn). Alphen aan den Rijn: Kluwer Law International.

Correa, C., Shashikant, S. and Meienberg, F. (2015) Plant Variety Protection in Developing Countries: A Tool for Designing a Sui Generis Plant Variety Protection System: An Alternative to UPOV 1991. Alfter: APBREBES.

Crucible II Group (2000) Seeding Solutions: Policy Options for Genetic Resources: People, Plants and Patents Revisited. Ottawa: International Development Research Centre.

Dahlberg, K. A. (1979) Beyond the Green Revolution. The Ecology and Politics of Global Agricultural Development. New York: Plenum Press.

De Schutter, O., UN Special Rapporteur on the Right to Food (2009) Seed Policies and the Right to Food: Enhancing Agrobiodiversity and Encouraging Innovation, UN Doc A/64/170.

Drahos, P. (1996) A Philosophy of Intellectual Property. Aldershot: Dartmouth.

Drahos, P. and Braithwaite, J. (2002) Information Feudalism: Who Owns the Knowledge Economy? London: Earthscan.

Dutfield, G. (2000) Intellectual Property Rights, Trade and Biodiversity: Seeds and Plant Varieties. London: Earthscan for IUCN.

Dutfield, G. (2010) 'Who Invents Life: Intelligent Designers, Blind Watchmakers, or Genetic Engineers?', Journal of Intellectual Property Law and Practice, 5(7): 531-540.

Dutfield, G. (2011) Food, Biological Diversity and Intellectual Property: The Role of the International Union for the Protection of New Varieties of Plants (UPOV), Intellectual Property Issue Paper no. 9. Geneva; New York: Quaker United Nations Office.

ETC Group (2010) Capturing Climate Genes. Ottawa: ETC Group.

FAO (1993) Harvesting Nature's Diversity. Rome: FAO.

FAO (2006) Report of the First Session of the Governing Body of the International Treaty on Plant Genetic Resources for Food and Agriculture, FAO Doc IT/GB01/06/ Report.

FAO (2007) Report of the Second Session of the Governing Body of the International Treaty on Plant Genetic Resources for Food and Agriculture, FAO Doc IT/GB-2/07/ Report.

Farmers' Rights Project (2009) 'India's Protection of Plant Varieties and Farmers' Rights Act'. Available at: www.farmersrights.org/bestpractices/success_seed_1.html (last accessed 6.11.2019).

Fowler, C. (1994) Unnatural Selection: Technology, Politics and Plant Evolution. Yverdon: Gordon and Breach.

Fowler, C., Smale, M. and Gaiji, S. (2000) Germplasm Flows between Developing Countries and the CGIAR: An Initial Assessment. Dresden: Global Forum on Agricultural Research Technical Report.

Frison, C. (2018) Redesigning the Global Seed Commons: Law and Policy for Agrobiodiversity and Food Security. Abingdon: Routledge.

Frison, C., López, F. and Esquinas-Alcázar, J. (eds) (2011) Plant Genetic Resources and Food Security: Stakeholder Perspectives on the International Treaty on Plant Genetic 
Resources for Food and Agriculture. Washington, DC: Routledge/Earthscan, FAO and Bioversity International.

Fujita, D., Rudi Trijatmiko, K., Grubanzo Tagle, A., Sapasap, M. V., Koide, Y., Sasaki, K., Tsakirpaloglou, N., Bueno Gannaban, R., Nishimura, T., Yanagihara, S., Fukuta, Y., Koshiba, T., Slamet-Loedin, I. H., Ishimaru, T. and Kobayashi, N. (2013) 'NAL1 allele from landrace increases yield in rice', Proceedings of the National Academy of Sciences, 110(51): 20431-20436.

Galluzzi, G., López Noriega, I. and Halewood, M. (2014) Non-Monetary Benefit Sharing Mechanisms within the Projects Funded by the Benefit Sharing Fund, Research Study 6. Rome: FAO.

Garine, É., Labeyrie, V., Violon, C., Wencélius, J., Leclerc, C. and Raimond, C. (2018) 'Which Scale to Understand Seed Fluxes in Small-Scale Farming Societies? Snapshots of Sorghum from Africa', in F. Girard and C. Frison (eds), The Commons, Plant Breeding and Agricultural Research. Abingdon: Routledge.

Glaeser, B. (2011) The Green Revolution Revisited: Critique and Alternatives. Abingdon: Routledge.

GRAIN (2014) Trade Agreements Privatising Biodiversity, update of November 2014. Barcelona: GRAIN.

Guneratne, C. (2012) Genetic Resources, Equity and International Law. Cheltenham: Edward Elgar.

Halewood, M. (2013) 'What Kind of Goods are Plant Genetic Resources for Food and Agriculture? Towards the Identification and Development of a New Global Commons', International Journal of the Commons, 7(2): 278-312.

Halewood, M., López Noriega, I. and Louafi, S. (eds) (2013a) Crop Genetic Resources as a Global Commons. Abingdon: Routledge.

Halewood, M., Andrieux, E., Crisson, L., Gapusi, J. R., Mulumba, J. W., Kouablan Koffi, E., Dorji, T. Y., Bhatta, M. R. and Balma, D. (2013b) 'Implementing "Mutually Supportive" Access and Benefit Sharing Mechanisms under the Plant Treaty, Convention on Biological Diversity, and Nagoya Protocol', Law, Environment and Development Journal, 9(1): 68-96.

Hammond, E. (2017) 'IRRI Seeks Patents on Yield-Boosting Gene Taken from Indonesian Farmers' Rice', TWN Info Service on Biodiversity and Traditional Knowledge. Penang: Third World Network.

Heath, C. and Kamperman Sanders, A. (eds) (2007) Intellectual Property and Free Trade Agreements. Oxford: Hart.

Helfer, L. R. (2003) 'Intellectual Property Rights and the International Treaty on Plant Genetic Resources for Food and Agriculture', Proceedings of the Annual Meeting of the American Society of International Law, 97: 33-35.

Helfer, L. R. (2004) Intellectual Property Rights in Plant Varieties: International Legal Regimes and Policy Options for National Governments, FAO Legislative Study 85. Rome: FAO.

Hess, C. (1993) 'Intellectual Property Rights: Protection of Plant Materials Public Research Agendas', in P. S. Baenziger, R. A. Kleese and R. F. Barnes (eds), Intellectual Property Rights: Protection of Plant Materials. Madison, WI: CSSA Special Publication.

Hope, J. E. (2004) Open Source Biotechnology, PhD Thesis, available at: http://papers. ssrn.com/sol3/papers.cfm?abstract_id=755244 (last accessed 4.8.2019).

International Assessment of Agricultural Knowledge, Science and Technology for Development (IAASTD) (2009) Agriculture at a Crossroads: Global Summary for Decision Makers. Washington, DC: IAASTD, Island Press. 
International Center for Tropical Agriculture (CIAT) (2009) 'New Legal Decision against Enola Bean', available at: www.ciatnews.cgiar.org/2009/07/22/new-legal-decisionagainst-enola-bean/ (last accessed 4.8.2019).

International Rice Research Institute (IRRI) (2006) Annual Report of the Director General 2005-2006. Los Baños, Philippines: IRRI.

Isiko Štrba, S. (2017) 'Legal and Institutional Considerations for Plant Variety Protection and Food Security in African Development Agendas: Solutions from WIPO?', Journal of Intellectual Property Law \& Practice, 12(3): 191-205.

ITPGRFA Secretariat (2012) Conservation and Sustainable Use under the International Treaty. Rome: FAO.

ITPGRFA Secretariat (2013) Report on the Implementation of the Multilateral System of Access and Benefit Sharing, FAO Doc IT/GB-5/13/5.

ITPGRFA Secretariat (2015) Typology of Users of the Multilateral System and their Regional Distribution, including PGRFA under Development, FAO Doc IT/OWGEFMLS-3/15/Inf.9.

ITPGRFA Secretariat (2018) 'International Treaty Fund Receives USD 119000 for Use of Plant Material', news release, available at: www.fao.org/plant-treaty/news/newsdetail/en/c/1143273/ (last accessed 7.8.2019).

Jasanoff, S. (2001) 'Ordering Life: Law and the Normalization of Biotechnology', Notizie di Politeia, 17(62): 34-50.

Kamau, E. C. and Winter, G. (2013) Common Pools of Genetic Resources: Equity and Innovation in International Biodiversity Law. Abingdon: Routledge.

Ker, C., Louafi, S. and Sanou, M. (2013) 'Building a Global Information System in Support of the International Treaty on Plant Genetic Resources for Food and Agriculture', in M. Halewood, I. López Noriega and S. Louafi (eds), Crop Genetic Resources as a Global Commons: Challenges in International Governance and Law. Abingdon: Routledge.

Kevles, D. J. (1994) 'Ananda Chakrabarty Wins a Patent: Biotechnology, Law, and Society', Historical Studies in the Physical and Biological Sciences, 25(1): 111-135.

Kloppenburg, J. (2014) 'Re-Purposing the Master's Tools: The Open Source Seed initiative and the Struggle for Seed Sovereignty', The Journal of Peasant Studies, 41(6): 1225-1246.

López Noriega, I., Wambugu, P. and Mejías, A. (2013) 'Assessment of Progress to Make the Multilateral System Functional', in M. Halewood, I. López Noriega and S. Louafi (eds), Crop Genetic Resources as a Global Commons: Challenges in International Governance and Law. Abingdon: Routledge

Louafi, S. (2013) 'Reflections on the Resource Allocation Strategy of the Benefit Sharing Fund', Policy Brief. Bern: Swiss Federal Office for Agriculture.

Louafi, S., Bazile, D. and Noyer, J. L. (2013) 'Conserving and Cultivating Agricultural Genetic Diversity: Transcending Established Divides', in É. Hainzelin (ed.), Cultivating Biodiversity to Transform Agriculture. Versailles: Quæ.

Louafi, S. and Welch, E. (2014) 'Open Systems Versus Strong Intellectual Property Rights: Disentangling the Debate on Open Access for Meeting Global Challenges in Life Science', in J. Y. Grosclaude, L. Tubiana and R. K. Pachauri (eds), A Planet for Life 2014: Innovation for Sustainable Development. Delhi: TERI.

Maxted, N., Kell, S. and Magos Brehm, J. (2011) Options to Promote Food Security: On-Farm Management and In Situ Conservation of Plant Genetic Resources for Food And Agriculture, CGRFA Background Study Paper 51. Rome: FAO. 
Moeller, N. I. and Stannard, C. (eds) (2013) Identifying Benefit Flows: Studies on the Potential Monetary and Non-Monetary Benefits Arising from the International Treaty on Plant Genetic Resources for Food and Agriculture. Rome: FAO.

Moldenhauer, H. and Hirtz, S. (2017) 'Monsanto and Co: From Seven to Four - Growing by Shrinking', in Heinrich Böll Foundation, Agrifood Atlas: Facts and Figures about the Corporations that Control What We Eat. Berlin: Heinrich Böll Foundation.

Mooney, P. (1983) 'The Law of the Seed: Another Development and Plant Genetic Resources', Development Dialogue, 1-2(21): 1-172.

Mooney, P. (1998) The Parts of Life. Agricultural Biodiversity, Indigenous Knowledge and the Role of the Third System. Uppsala: Dag Hammarskjöld Foundation.

Moore, G. and Goldberg, E. (eds) (2010) The International Treaty on Plant Genetic Resources for Food and Agriculture: Implementing the Multilateral System. Learning Module. Rome: Bioversity International.

Morgera, E., Tsioumani, E. and Buck, M. (2014) Unraveling the Nagoya Protocol: A Commentary on the Nagoya Protocol on Access and Benefit-Sharing to the Convention on Biological Diversity. Leiden: Brill.

Morgera, E. (2016) 'The Need for an International Legal Concept of Fair and Equitable Benefit Sharing', European Journal of International Law, 27(2): 353-383.

Nuffield Council on Bioethics (2002) The Ethics of Patenting DNA. A Discussion Paper. London: Nuffield Council on Bioethics.

Oberthür, S., Gerstetter, C., Lucha, C., McGlade, K., Pozarowska, J., Rabitz, F. and Tedsen, E. (2011) Intellectual Property Rights on Genetic Resources and the Fight against Poverty, European Parliament, EP/EXPO/B/DEVE/FWC/2009-01/Lot5/20.

Oguamanam, C. (2006) 'Regime Tension in the Intellectual Property Rights Arena: Farmers' Rights and Post-TRIPS Counter Regime Trends', Dalhousie Law Journal, 29(2): 413-454.

Oguamanam, C. (2015) 'Breeding Apples for Oranges: Africa's Misplaced Priority Over Plant Breeders' Rights', Journal of World Intellectual Property, 18(5): 165-195.

Özgediz, S. (2012) The CGIAR at 40: Institutional Evolution of the World's Premier Agricultural Research Network. Washington, DC: CGIAR Fund Office.

Petit, M., Fowler, C., Collins, W., Correa, C. and Thornström, C.-G. (2001) Why Governments Can't Make Policy: The Case of Plant Genetic Resources in the International Arena. Lima: CIP.

Pistorius, R. (1997) Scientists, Plants and Politics: A History of the Plant Genetic Resources Movement. Rome: International Plant Genetic Resources Institute.

Prifti, V. (2015) The Breeder's Exception to Patent Rights: Analysis of Compliance with Article 30 of the TRIPS Agreement. Berlin: Springer.

Raustiala, K. and Victor, D. G. (2004) 'The Regime Complex for Plant Genetic Resources', International Organization, 58(2): 277-309.

Rose, G. L. (2004) 'The International Undertaking on Plant Genetic Resources for Food and Agriculture: Will the Paper be Worth the Trees?', in N. P. Stoianoff (ed.), Accessing Biological Resources: Complying with the Convention on Biological Diversity. The Hague; London: Kluwer Law International.

Scarascia-Mugnozza, G. T. and Perrino, P. (2002) 'The History of Ex Situ Conservation and Use of Plant Genetic Resources', in J. M. M. Engels, V. Ramanatha Rao, A. H. D. Brown and M. T. Jackson (eds), Managing Plant Genetic Diversity. Rome: IPGRI.

Seyoum, A. and Welch, E. (2013) 'Trading off Use Restrictions and Benefit-Sharing for Genetic Materials for Food and Agriculture with an Emphasis on Upfront Payments', Paper presentation at the 53rd Annual Conference of the German Society of Economic and Social Sciences in Agriculture. Berlin: GEWISOLA. 
Shaheed, F., UN Special Rapporteur in the Field of Cultural Rights (2012) Report on the Right to Enjoy the Benefits of Scientific Progress and its Applications, UN Doc A/ $\mathrm{HRC} / 20 / 26$.

Silva Repetto, R. and Cavalcanti, M. (2000) Multilateral Trade Negotiations on Agriculture. A Resource Manual IV: TRIPS Agreement. Rome: FAO Legal Office.

Swiss Government (2015) Report of Multi-Stakeholder Workshop Organized by Switzerland - The International Treaty on Plant Genetic Resources for Food and Agriculture: What Investment Strategy for the Benefit-sharing Fund?, FAO Doc IT/GB-6/15/ Inf.13.

Switzer, S., Morgera, E., Tsioumani, E. and Burci, G. L. (2019) 'Biodiversity, Pathogen Sharing and International Law', in S. Negri (ed.), Environmental Health in International and EU Law: Current Challenges and Legal Responses. Abingdon: Routledge.

Taylor, P. (2012) 'The Common Heritage of Mankind: A Bold Doctrine Kept within Strict Boundaries', in D. Bollier and S. Helfrich (eds), The Wealth of the Commons: A World beyond Market and State. Amherst and Florence, MA: Levellers Press.

Third World Network (2015) 'Comments Submitted to the ITPGRFA Secretariat', available at: www.fao.org/fileadmin/user_upload/faoweb/plant-treaty/WGMLS/Appendix_12.pdf (last accessed 9.8.2019).

Tsioumani, E. (2004) 'International Treaty on Plant Genetic Resources for Food and Agriculture: Legal and Policy Questions from Adoption to Implementation', Yearbook of International Environmental Law, 15(1): 119-144.

Tsioumani, E. (2014) 'Plant Treaty Governing Body Identifies Need to Enhance Multilateral System of Access and Benefit-sharing', BeneLex Blog, available at: https:// benelexblog.wordpress.com/2014/02/19/plant-treaty-governing-body-identifies-needto-enhance-multilateral-system-of-access-and-benefit-sharing/ (last accessed 4.8.2019).

Tsioumani, E. (2015) 'The Plant Treaty at a Crossroads: Reflections on the Sixth Session of the ITPGR Governing Body', BeneLex Blog, available at: https://benelexblog. wordpress.com/2015/12/18/sixth-session-of-the-itpgr-governing-body/ (last accessed 4.8.2019).

Tsioumani, E. (2018) 'Beyond Access and Benefit-Sharing: Lessons from the Law and Governance of Agricultural Biodiversity", Journal of World Intellectual Property, 21(3-4): 106-122.

Tsioumani, E. (2019) ‘A Missed Opportunity for Multilateralism', Environmental Policy and Law, 49(6): 320-323.

Tsioumani, E., Muzurakis, M., Ieropoulos, Y. and Tsioumanis, A. (2016) 'Following the Open Source Trail outside the Digital World: Open Source Applications in Agricultural Research and Development', tripleC: Communication, Capitalism and Critique, 14(1): $145-162$.

Tsioumani, E., Finnegan, L. and Tsioumanis, A. (2017) 'Summary and Analysis of the Sixth Meeting of the Working Group to Enhance the Functioning of the Multilateral System of the International Treaty on Plant Genetic Resources for Food and Agriculture', Earth Negotiations Bulletin (ENB), 09(685), International Institute for Sustainable Development.

Tsioumani, E., Pereira de Andrade, P. and Schabus, N. (2019a) 'Summary and Analysis of the Ninth Meeting of the Working Group to Enhance the Functioning of the Multilateral System of the International Treaty on Plant Genetic Resources for Food and Agriculture', Earth Negotiations Bulletin (ENB), 09(731), International Institute for Sustainable Development.

Tsioumani, E., Finnegan, L., Schabus, N., Tsioumanis, A. and Willetts, L. (2019b) 'Summary of the Eighth Session of the Governing Body of the International Treaty on 
50 Benefit-sharing in agricultural research

Plant Genetic Resources for Food and Agriculture', Earth Negotiations Bulletin (ENB), 09(740), International Institute for Sustainable Development.

UNDP (2000) Human Development Report 2000: Human Development and Human Rights. New York: Oxford University Press.

UPOV (2003) Access to Genetic Resources and Benefit-Sharing. Geneva: International Union for the Protection of New Varieties of Plants.

UPOV (2019) 'Overview of UPOV', available at: www.upov.int/edocs/pubdocs/en/ upov_pub_437.pdf(last accessed 4.8.2019).

Weissbrodt, D. and Schoff, K. (2003) 'Human Rights Approach to Intellectual Property Protection: The Genesis and Application of Sub-Commission Resolution 2000/7', Minnesota Intellectual Property Review, 5: 1-46.

Yamane, H. (2011) Interpreting TRIPS: Globalisation of Intellectual Property Rights and Access to Medicines. Oxford: Hart.

Yamin, F. (2003) 'Intellectual Property Rights, Biotechnology and Food Security', IDS Working Paper 203, available at: www.ids.ac.uk/publication/intellectual-propertyrights-biotechnology-and-food-security (last accessed 7.5.2020). 


\section{Fair and equitable benefit- sharing in land governance for sustainable agriculture}

\section{Introduction}

As explored in detail in the previous chapter, the concept of fair and equitable benefit-sharing was born and developed in the context of international law and policy related to bio-based research and development. Aiming to ensure some portion of the benefits arising from the use of their genetic resources against the privatization trend promoted by the strengthening of IPRs, developing countries pushed for a major shift in the regulation of access to such resources. As a result, fair and equitable benefit-sharing became the objective of legally binding treaties, including the CBD and the ITPGRFA, in the latter case accompanied by sophisticated implementation mechanisms. Despite the questionable success of implementation efforts to inject fairness and equity in agricultural research and development, mainly due to the conflicting legal framework described above, I argue that the objective of fair and equitable benefit-sharing introduces both legally binding obligations for the parties of these treaties and a sharing ethos in international environmental law. This ethos may have the potential to eventually change the paradigm, affecting the acceptability and legitimacy of policy action beyond strict legal frameworks. Within this line of argumentation, in this chapter I explore expressions of benefit-sharing in the governance of land for agricultural purposes in the following contexts: farmers' rights, and benefitsharing from public lands, including the specific case of large-scale agricultural investments.

Importantly, due to characteristics of the land sector explored below, the emergence of the concept of fair and equitable benefit-sharing cannot be clearly traced as part of a chronological line of evolution of policies and principles. On the contrary, applications of benefit-sharing are rather ad hoc. Compared to the field of agricultural research and development, international instruments specifically related to land governance are less binding, references to benefitsharing less explicit and benefit-sharing systems less developed. Examination of benefit-sharing is inextricably linked to redistribution efforts for land or agrarian reform, which have marked human history ever since Solon's and Tiberius' land reform laws in ancient Athens and Rome respectively (Adams 1995; Groppo 2003; Binswanger-Mkhize et al. 2009). Specific contributions to the study of 
benefit-sharing can be identified in the ITPGRFA provisions and related policies on farmers' rights; soft law, including the Voluntary Guidelines on the Responsible Governance of Tenure of Land, Fisheries and Forests in the Context of National Food Security (VGGT), ${ }^{1}$ the Voluntary Guidelines to support the Progressive Realization of the Right to Adequate Food in the Context of National Food Security (Right to Food Guidelines) ${ }^{2}$ and the recently adopted UN Declaration on the Rights of Peasants and Other People Working in Rural Areas; ${ }^{3}$ and the growing body of international jurisprudence in the context of human rights treaties and investment agreements. These will be critically explored in the contexts identified above.

Academic and policy analyses of benefit-sharing from land use have largely focused on schemes aiming to support the effectiveness and legitimacy of programmes to reduce emissions from deforestation and forest degradation and to conserve, manage forests sustainably and enhance forest carbon stocks in developing countries (REDD+) (Pham et al. 2013; Weatherley-Singh and Gupta 2015; Brockhaus et al. 2014; Peskett 2011; Vijge et al. 2016; Luttrell et al. 2013; McDermott et al. 2013; Wong et al. 2019). Benefit-sharing in REDD+ projects rests outside the scope of this chapter. A review of this literature, however, helped frame and inform my exploration of benefit-sharing applications in the field of land for food and agriculture.

\section{Differentiating land use from genetic resource use}

My analysis starts from the observation that there are fundamental elements that differentiate the regulation of benefit-sharing from land use compared to benefitsharing from genetic resource use for research and development. These elements are related to the nature of the resource, the scope of the regulation and the determination of beneficiaries.

When it comes to the nature of the resource, land was traditionally considered renewable, but fixed in supply. In the context of soil and natural resource degradation and population growth, the land resource base is considered to be shrinking, and policies are required to accommodate competing uses and overlapping claims. Soil in particular is considered a non-renewable, finite resource, meaning its loss and degradation is not recoverable within a human lifespan (Smith et al. 2010; Fischer et al. 2011). Genetic resources, on the other hand, are renewable and easily multiplied. Usually a very small quantity is required for breeding, research and development (Guneratne 2012), and such activities can be conducted in parallel and indefinitely by several users. Restrictions in use of genetic resources stem solely from legal limitations, such as IPRs and ABS laws, while sustainability considerations weigh in in exceptional cases of limited supply of biological resources. Restrictions in land use, on the other hand, come from both material limitations, i.e. the limited resource base, and legal limitations, such as ownership and other land-related rights.

When it comes to regulation, benefit-sharing arising from the use of genetic resources is primarily guided by international law and operates at the inter-state 
level. The ABS-related treaties, including the CBD and its Nagoya Protocol, and the ITPGRFA, point to transactions between providers and users of genetic resources situated in different countries. The only intra-state benefit-sharing obligation, referring to an internal, state-to-community obligation, concerns the obligation for parties to the Nagoya Protocol to share benefits with indigenous peoples and local communities within their territories, who hold genetic resources and traditional knowledge used for research and development purposes (Morgera et al. 2014). This obligation builds on the CBD provision concerning respect for traditional knowledge and benefit-sharing from its utilization (CBD Art. 8(j)). In contrast, benefit-sharing from land use is primarily guided by national laws and operates at the intra-state level. As explored below, land governance remains mostly an issue for national legislation, although international norms increasingly come into play with regard to human rights considerations, indigenous peoples' claims and environmental concerns (Cotula 2017a). An exception to the intra-state nature of benefit-sharing from land use could be the benefit-sharing arrangements linked to transnational investment agreements, in case such arrangements are not mediated by the state receiving the investment.

Furthermore, benefit-sharing from genetic resource use emerged as a new concept in international biodiversity law, filling a gap and aiming to pursue fairness and equity considerations in bio-based research and development. Benefit-sharing in land governance, on the other hand, came more as an afterthought in an already complex field, ripe with often competing objectives, rights and arrangements, in which distribution has always been a central issue. Particular difficulties thus arise with regard to the relationship between land rights and benefit-sharing, the crucial questions touching upon both the resource itself and determination of the beneficiaries: who has control and decisionmaking capacity over land use? Who has the power to determine the preferred benefits? And can this power be replaced by benefits, monetary or nonmonetary, as determined by outsiders, i.e. the government or an investor? Under which circumstances are rights holders reduced to beneficiaries under benefitsharing arrangements, and under which conditions can benefit-sharing contribute to justice in land governance?

\section{Discussing beneficiaries}

Determination of the beneficiaries is far more complex and context-specific when it comes to benefit-sharing from land use. As analysed in the first chapter, benefit-sharing from genetic resource use was based on the principle of national sovereignty over natural and genetic resources. The providers of genetic resources were thus deemed beneficiaries in benefit-sharing arrangements as owners or stewards of the resource; ownership was the criterion used to pursue justice in a Lockean sense of the term. As explored below, however, beneficiaries of benefit-sharing from land use can be identified on the basis of various, often contradictory, terms. Using Amartya Sen's famous parable of the 


\section{Benefit-sharing in land governance}

flute $^{4}$ to navigate through justice principles (Sen 2009), I loosely structure beneficiaries in the land sector around the criteria of ownership, merit and vulnerability. Ownership would come into play with regard to private individuals or communities, including indigenous peoples, who assert control rights over land, as detailed below. Merit would be used as a criterion in cases for instance of land concessions to smallholder farmers and agricultural producers in general, in the pursuit of public-interest objectives including food security, agricultural productivity and rural livelihoods; the criterion of vulnerability would be prioritized in cases of land allocation for the benefit of the rural poor or the landless, including women.

This is of course a highly schematic and thus problematic framework. The range of conceptual differentiations around the globe when it comes to land tenure, for instance, provides an illustration of the challenges involved in applying the ownership criterion. As examined below, statutory systems usually co-exist with customary ones, and private with state and collective property, while legitimate uses of the same land are often overlapping or conflicting. In addition, in most jurisdictions, states have powers of eminent domain; they can thus expropriate property even against the will of the owner under conditions, including payment of compensation.

The distinctive features of property in the civil-law tradition would generally refer to the owner's rights to possess, use and dispose of the property in question. Understanding of property in common-law systems, on the other hand, is less unitary and would include the 'bundle of rights' popularized by Edella Schlager and Elinor Ostrom in their seminal 1992 paper in the context of common property regimes: the rights of access, withdrawal (of benefits), management, exclusion (of others) and alienation (i.e. transfer of the right) (Schlager and Ostrom 1992), accompanied by the expectation of legal protection (Cotula 2016). The lack of clarity and understanding of common property regimes and community customary systems of land and natural resource use result in lack of legal recognition, which impacts on the identification of rights holders as beneficiaries, and undermines the lives and livelihoods of millions, as explored below.

Furthermore, real-life situations are never clear and groups of beneficiaries are never homogeneous. Vast differences exist around the globe within each categorization, such as 'indigenous peoples' or 'smallholder farmers', depending on historical, socio-economic, cultural and geographical specificities, while even narrowly defined communities, geographically and culturally close, rarely share unanimously the same views regarding development choices. Policy decisions would further need to address cases of conflicting uses by different groups of beneficiaries, and overlapping claims regarding land use. In addition, challenges arise with regard to the identification of which individuals belong to specific groups of beneficiaries and which ones are excluded, and the criteria to be used for such identification.

Questions of terminology also remain open to debate. The use of and relationship between 'beneficiaries' and 'rights holders' is not clear. The term 
'beneficiary' has passive connotations, and usually refers to someone who simply receives benefits, without contributing to their creation or accumulation. This fails to capture the majority of situations where benefit-sharing is sought, and may result in confusion. For this reason, analyses of benefit-sharing under REDD+ project implementation have called for a rights-based approach, which requires engagement with indigenous men and women as rights holders, rather than as project beneficiaries (Sarmiento Barletti and Larson 2017).

Finally, public support to a specific group through policy decisions and implementation may be deterred by hostile or indifferent power structures and/or overarching socio-economic choices related to the preferred model of agriculture and development. Smallholder farmers, the focus of this chapter, would generally be a group satisfying most aspects of the justice-related criteria: ownership, merit and vulnerability. Difficulties of identification aside, smallholder farmers are responsible for a large amount of agricultural production in developing countries and local food security, have been contributing to the conservation sustainable use of agricultural biodiversity through their customary practices, live mostly in rural areas and constitute part of populations identified as extremely poor. Smallholder farmers face various challenges in supporting their livelihoods, largely stemming from the rapidly changing political, economic, social and environmental landscape (IFAD 2013). These challenges range from land and natural resource grabbing and land tenure insecurity to insecure market access and an inability to elicit benefits from markets due to a lack of physical access to urban markets because of failing infrastructure, a lack of access to information and financial services and an inability to cope with stringent certification, export and food safety standards (Lee et al. 2012; Le Courtois et al. 2011). While their contribution to sustainable development, food security and nutrition was particularly highlighted by FAO during 2014, proclaimed as the International Year of Family Farming, their land rights remain vulnerable, they usually receive limited support from the public sector and an enabling legal and policy environment at the international (and domestic) level is lacking, as explored below.

But first I will start by drawing a general picture of the trends behind land governance, including the central role of domestic law and the emergence of international regulation.

\section{Setting the scene: land for food and agriculture}

Land has had a central position throughout human history as the basis for livelihoods and wellbeing, culture and identity, but also statehood and political power. It supports most productive human activities, including agriculture, hosts many of the world's ecosystems and natural resources and has a political and cultural significance both for the nation-state and for indigenous peoples and local communities (FAO 2002a). Far from being symbolic, this significance of land has manifested itself in wars and different kinds of conflict. Depending on its management, land can support environmental sustainability and social justice, or not. 
A review of literature on land rights and policies of relevance to agriculture and food security (FAO 2002a; Carter 2003; Oxfam et al. 2016; Cotula 2017a) has resulted in a series of general observations which necessarily frame my analysis of benefit-sharing. These observations, which I briefly address below, include:

- chronic inequality in land distribution in many countries;

- gender as a decisive element of land poverty;

- the primacy of domestic law, the existence of vast differences around the world regarding land law;

_ interactions between formal systems and customary arrangements; and

- the relatively recent emergence of international law, mainly related to indigenous peoples' rights and human rights in general, environmental considerations and market liberalization.

\section{Land distribution, social justice and economic growth}

Control of rights to land has historically been an instrument of oppression and colonization (Gilbert 2013). Inequitable distribution of land ownership remains acute in many parts of the world today. This has created several land rights movements around the globe, demanding land redistribution, recognition of customary - in cases communal - rights to land and more recently the right to control the type of development undertaken. Such movements indicate that the land issue is inextricably linked with social justice. At the same time, the relationship between resource distribution and economic growth has a permanent importance in the research agenda of economists and international institutions (Cipollina et al. 2018). High land concentration has been historically linked to economic inequality, social instability and environmental degradation, exacerbating the problems of landlessness, social tension and unsustainable use of marginal or environmentally sensitive lands (Russett 1964; FAO 2002a; Stiglitz 2012).

State-mandated land reform efforts to address redistribution concerns were undertaken in the post-war period with mixed results. Doreen Warriner (1969) has systematically assessed a series of such land or agrarian reforms under different political and socio-economic contexts. She reached the still topical conclusion that land reforms increase political liberty but stimulate development only if planned and implemented to suit local conditions rather than follow foreign or externally imposed solutions.

In the Cold War era, land reforms fell out of favour with donors and stopped, with the exception of sporadic efforts in the 1980s such as in Ethiopia and the Philippines, which resulted from shifts in the domestic balance of power between landowners and peasants (Adams 1995). Later, intensive land redistribution processes took place under specific historic conditions: the decollectivization and redistribution of state land to private persons in Central and Eastern Europe and the former Soviet Union; the land reform and restitution 
programme in post-Apartheid South Africa, to address racially skewed land ownership; and land reform programmes in post-conflict societies such as Cambodia, Burundi and Rwanda, to accommodate the return of displaced persons (Adams 1995; FAO 2002a). More recently, land rights reforms have been receiving renewed attention as instruments to redress rural poverty by enhancing the land access and tenure security of poor households (FAO 2002a; Carter 2003). These policy debates have largely reflected the World Bank's focus on the assignment of legally secure, usually marketable, individual land rights and market-assisted land reform (World Bank 2003). At the same time, commercial pressure on agricultural (and other) land in many developing countries has been increasing very rapidly in recent years, especially through foreign direct investments - a phenomenon dubbed in critical literature as land-grabbing (Cipollina et al. 2018; Cotula 2015).

\section{Gendering the land question}

To quote Bina Agarwal (2003), gendering the land question remains critical, for policymakers and academics alike. In her seminal study on gender and land rights, Agarwal sees the gender gap in the ownership and control of property as the single most critical contributor to the gender gap in economic wellbeing, social status and empowerment (Agarwal 1994). Land rights are extremely important for rural women, because they affect both their livelihoods directly, and their bargaining power within the household, their community and the society at large (FAO 2002a), particularly since empirical research shows that women often hold the prime responsibility for food production (FAO 2002b). In addition, literature on intra-household expenditure patterns suggests strongly that women tend to dedicate greater proportions of their income to household public goods, including food, child health and education (Carter 2003). Finally, land rights increase women's resilience and independence in the event or the death of or divorce from their spouse.

Admittedly, societal transformation when it comes to gender is an extremely complex issue, ranging far beyond formal and customary legal systems, to also encompass socio-cultural norms and family- and education-related biases. Cecile Jackson (2003: 477), for instance, prioritizes ethnographic research that focuses on social change, considers the diversity of subject positions and subjectivities of women in relation to land and situates gendered property relations within broader contexts related to marriage, kinship and livelihoods. While the transformative power of law remains a topic for intense debate, with respect to whether the attribution of land rights will effectively transform women's position in societies or not, there is no doubt that lack of such rights constitutes an unparalleled institutional obstacle to women's empowerment. In this regard, international bodies, for instance, under the 1979 Convention on the Elimination of All Forms of Discrimination against Women and the VGGT, have advocated for specifically addressing gender equality in land and other related legislation. As a result, legislative developments since the 1990s have paid greater attention 
to the issue, by embracing the principle of non-discrimination, abrogating archaic customary norms disadvantaging women, promoting joint ownership of family land and providing for women's representation in land management bodies (FAO 2002a). Obviously challenges remain in many countries around the world.

\section{The central position of domestic law}

The political significance of land and its links to state sovereignty have made land rights and administration remain subjects for domestic law. Each country's land laws are unique, reflecting its political history, legal tradition and social experience. Some general trends can be discerned, however.

According to the FAO (2002c), land tenure rights are often classified as 'formal' or 'informal'. Formal rights are those explicitly acknowledged by the state, while informal are the rights lacking official recognition. Customary or traditional rights of indigenous peoples and local communities often fall under the 'informal' rights category, although they may be quite formal and secure within their own context. In addition, the distinction between formal and informal is becoming increasingly blurred, as many countries provide legal recognition and protection to customary rights as a result of constitutional amendments and related jurisprudence, in response to a hopefully globally changing paradigm. Land rights then typically include rights to use, control and transfer. They usually fall under more general legislation including land laws, land tenure agreements and planning regulations, and they are often overlapping or competing, creating land disputes. Another common categorization concerns the distinction between private, state-owned and communal land.

In addition to these categorizations, land governance in most jurisdictions around the globe has responded to a series of trends (FAO 2002a): increased recognition of indigenous peoples' rights; environmental considerations; rural development and food security considerations; and privatization and creation of land markets, increasingly transnational ones. Often emerging at the international level, these trends are explored below.

\section{The emergence of international law}

Land has a particular importance for international law, as an element of statehood and political organization, tightly linked to sovereignty (Cotula 2017a). Land governance, on the other hand, was not traditionally considered a topic for international law. International law and policy emerged relatively recently, following the realization that land tenure and management affect a a series of internationally recognized human rights and underpin all environmental regulation efforts. Policies to support sustainable land management were therefore deemed essential for a series of environmental, economic and social reasons. Sustainable land management leads to increased soil fertility and thus agronomic productivity, for food security and improved livelihoods. It enables 
carbon capture and storage, and thus climate change mitigation, and supports biodiversity conservation, disaster risk management and various ecosystem functions such as soil maintenance. Land is also inextricably linked with rural livelihoods and the survival and identity of indigenous peoples.

Agenda 21, the non-binding action plan adopted at the 1992 Earth Summit, recognized the need for integrated planning and management of land resources, stating that it should be a decision-making process that 'facilitates the allocation of land to the uses that provide the greatest sustainable benefits' ${ }^{5}$ Efforts by multilateral environmental agreements, however, remain slim to date. It was in the context of the 2008 global food crisis (Headay and Fan 2010) and the emerging web of transnational investments in agricultural land (Cotula 2015) that land governance became an issue of common concern, of particular importance for food security and human development. Arable lands are becoming increasingly valuable, due to population growth and environmental change, attracting the interest of investors and raising a host of associated issues with regard to local livelihoods. As Gilbert (2013) argues, large-scale transnational agricultural investments (dubbed as land grabs), alongside the acquisition of lands for biofuels in the context of climate change-related measures, have been creating a pattern of land use for economic gain to the detriment of local livelihoods. This section will provide a glimpse of international efforts of relevance to land governance under human rights instruments, environmental treaties, and non-binding governance frameworks related to rural development, in the context of the increasing relevance of international investment law, which comes into play in the case of large-scale agricultural investments affecting control over land and natural resources.

While it is widely recognized that land rights are linked to the realization of several recognized human rights, such as the right to property and to food, and the rights of indigenous peoples, existing treaties do not recognize a human right to land as such (Gilbert 2013; Cotula 2017a). However, a growing acknowledgement of the linkages between land claims and international human rights law has emerged in the context of jurisprudence of international and regional human rights courts, as well as in the work of UN Special Rapporteurs. These linkages are particularly prominent in the context of indigenous peoples' rights, and the rights of peasants, briefly addressed below, in turn.

\section{Land and indigenous peoples}

The land tenure situation of indigenous peoples is closely related to the history of colonial and nation-state policies towards them, resulting in dispossession, displacement, marginalization and assimilation (Colchester 2001). Discriminatory land policies started shifting slowly at the end of the twentieth century towards multicultural approaches and recognition of customary rights. Despite the huge diversity that characterizes them, indigenous peoples around the world have stressed the special connection between land and territory, traditional livelihoods, cultural identity and self-determination. These linkages are 
increasingly recognized at the international level. For the time being, this recognition is reflected less in lawmaking and more in the expanding interpretation of existing international law.

Albeit of limited state membership, the 1989 Convention no. 169 of the International Labour Organization (ILO) concerning Indigenous and Tribal Peoples in Independent Countries requires states to recognize the rights of indigenous peoples over the lands they traditionally occupy and their natural resources, and to respect the special importance of lands or territories for cultures and spiritual values (Arts 13-16). The UN Human Rights Committee has interpreted the cultural rights protected under Article 27 of the International Covenant on Civil and Political Rights (ICCPR) as extending to the protection of a particular way of life associated with the use of land resources, including traditional activities as fishing and hunting and the right to live in reserves protected by law (UN Human Rights Committee 1994). Regional human rights bodies and courts have also elaborated on the relationship between land, livelihoods and culture. Jérémie Gilbert in particular argues that regional human rights bodies acknowledge indigenous land rights as part of a larger bundle of rights including property rights, cultural rights and social rights (Gilbert 2013). The Inter-American Court of Human Rights has developed extensive jurisprudence linking indigenous peoples' land rights to cultural rights, the right to property, the right to life and the right to health (Anaya 2005; Cotula 2017a). In the 2001 Awas Tingni case, ${ }^{6}$ for instance, the Inter-American Court recognized indigenous peoples' collective rights to land and resources on the basis of the right to property, protected under Article 21 of the American Convention on Human Rights, ${ }^{7}$ noting that the human right to property embraces the communal property regimes as defined by indigenous peoples' own customs and traditions (Anaya 2005). The case concerned a logging concession of 62,000 hectares of tropical forest in communal lands to be commercially developed by a company. African case law is more limited but growing, featuring the protection of collective land rights under the rights to property, culture and access to natural resources, according to the African Charter on Human and Peoples' Rights. ${ }^{8}$ In the 2010 Endorois case, ${ }^{9}$ the African Commission on Human and Peoples' Rights found that eviction of the Endorois community from their ancestral lands by Lake Bogoria for the purposes of creating a game reserve disrupted their pastoral way of life and caused damage to their livelihoods, culture and religious practices. It therefore violated several of their rights, including their right to property, culture, religion, free disposition of natural resources, and development.

The gradual policy shift towards recognition of indigenous peoples' rights has arguably culminated to the adoption of the UN Declaration on the Rights of Indigenous Peoples (UNDRIP), ${ }^{10}$ which recognizes indigenous peoples' land rights (Art. 26), including their distinctive spiritual relationship with their lands (Art. 25), the right to their conservation and protection (Art. 29) and their right to determine development priorities (Art. 32). While UNDRIP is formally a soft-law instrument, it can be argued that it reflects current understandings of international law regarding indigenous peoples' rights and integrates a high 
degree of political consensus. In addition, it produces indirect legal effects by providing a reference point for regional and national courts (Cotula 2017a).

The contribution of indigenous peoples' traditional knowledge when it comes to land management is also recognized in environmental treaties. The UN Convention to Combat Desertification (UNCCD) ${ }^{11}$ focuses on sustainable land management as the main strategy to combat desertification and land degradation and mitigate the effects of drought with a view to contributing to sustainable development in affected areas (Tsioumani 2017). The UNCCD strongly promotes a people-centred and participatory approach to sustainable land management (Stringer et al. 2007), in synergy with the food security, climate change and biodiversity agendas. It recognizes the value of local and traditional knowledge with regard to natural resource management, and promotes exchange of such knowledge and integration in research and development processes, with appropriate return of the benefits derived from it to the local populations concerned, on an equitable basis and on mutually agreed terms (UNCCD Arts 16-17). In addition, the Regional Implementation Annex for Africa requires African Parties to sustain and strengthen reforms currently in progress towards greater decentralization and resource tenure (Art. 4(2)(b)). Lorenzo Cotula (2017) highlights this as a rare example of policymaking under environmental treaties dealing explicitly with land tenure. He notes that the rationale is that more secure tenure rights are more likely to create incentives for landholders to use land sustainably, drawing attention, however, to empirical evidence highlighting that customary tenure systems can often provide greater security than national legislation. The UNCCD focus on land tenure is expected to be expanded; at the latest meeting of the Conference of the Parties in 2019, parties decided to include land tenure as a thematic issue, and encouraged recognition of legitimate tenure rights, including customary rights, in a way that is consistent with national legal frameworks, and following the VGGT. ${ }^{12}$

Along similar lines, the CBD has acknowledged the linkages between land tenure security and the status of traditional knowledge, identifying land tenure security as an indicator for achieving the Aichi Target on respecting traditional knowledge and integrating it in CBD implementation by $2020 .{ }^{13}$ Traditional knowledge of indigenous peoples and local communities of relevance to the conservation and sustainable use of biological diversity is a cross-cutting issue area under the Convention. Such traditional knowledge is not static but evolves over time, incorporating elements of experimentation and integrating new ideas. A necessary precondition for this evolution is the interaction with the natural resource itself, in this case the land and the environment. Strengthening tenure security therefore through access and land rights in line with customary practices is considered vital, both for traditional knowledge preservation and sustainable land management (Tsioumani 2017). In addition, a series of decisions on impact assessment have been adopted in the CBD context. In particular the Akwé: Kon voluntary guidelines for the conduct of cultural, environmental and social impact assessments $^{14}$ are of direct relevance to national-level decisions on land use, including in the context of large-scale agricultural investments. 
Both the UNCCD and the CBD create legal obligations for states. Implementation, however, is not supported by an international enforcement mechanism. In addition, challenges related to compliance persist mainly due to limitations in administrative, technical and financial capacities of national governments, and lack of integration of sustainable land management and biodiversity issues respectively into national development planning (Morgera et al. 2012; Ambalam 2014). However, implementation of environmental standards can be supported by unexpected means, including, increasingly, the human rights machinery (Morgera 2019). A notable example includes the Saramaka case,${ }^{15}$ involving state concessions in the Saramaka territory. In the interpretation of its decision, ${ }^{16}$ the Inter-American Court of Human Rights referred to the Akwé: Kon guidelines as 'one of the most comprehensive and used standards' for impact assessments in the context of indigenous and tribal peoples. ${ }^{17}$ Impact assessments would come into play in the case of investment agreements on natural resource use, as addressed below, as well as with regard to implementation of conservation measures, such as establishment of protected areas, which have historically resulted in injustices and impoverishment, partly by ignoring local uses of land and resources (Stevens 1997; Brockington 2004; Robinson et al. 2018).

\section{Land and smallholder farmers}

Choices regarding development models, traditionally made by a centralized decision-making authority, affect populations beyond indigenous peoples, who are generally self-identified as such, with a distinct sense of identity and strong links to territories. Investment agreements usually have impacts on communities living in geographic proximity of the project. Choices regarding models of agricultural development, on the other hand, impact on all the rural populations, including more specific sets of groups generally characterized as vulnerable, such as smallholders, family farmers and peasants, but also the rural poor and the landless.

The legal framework concerning indigenous peoples' rights is broadly related to their right of self-determination, recognized following a history of colonization and conquest. The rights of local communities and of smallholders, on the other hand, have emerged more recently in international law, and are related to participatory rights, as well as to livelihoods, food security and rural development considerations. They have emerged in human rights case law, as well as in the VGGT and the UN Declaration on the Rights of Peasants.

The first global instrument addressing land tenure in detail, the non-binding VGGT establish a legal framework calling for recognizing and respecting legitimate tenure rights, including customary rights. Seeking to improve governance of tenure 'for the benefit of all, with an emphasis on vulnerable and marginalized people' (Art. 1(1)), the Guidelines recognize the centrality of secure tenure rights and equitable access to land, fisheries and forests for development, and acknowledge that inadequate and insecure tenure rights increase vulnerability, hunger and poverty, and can lead to conflict and 
environmental degradation. Notwithstanding their non-binding nature, the legal significance of the Guidelines stems from the fact that they have been adopted following a very inclusive multi-stakeholder process of intergovernmental negotiations and they enjoy high-level political legitimacy, expressed, among others, in the 2012 Outcome Document of the Rio+20 Conference ('The Future We Want') and the G20 Leaders Declaration of June 2012. The VGGT are thus well-positioned to influence national-law developments (Tsioumani 2017). Cotula (2017b) further points out that, in addition to reflecting existing international law on human rights and related jurisprudence, the use in the VGGT of extra-legal concepts, such as 'governance' and 'tenure', could arguably facilitate the adaptation of VGGT guidance into different legal contexts. As an illustration, Scotland's Land Reform Act 2016 refers to the VGGT as an international instrument that the Scottish government must take into consideration when developing guidance about engaging communities in decisions relating to land (Cotula 2017b).

The UN Declaration on the Rights of Peasants, adopted by the UN General Assembly in December 2018, also has a very broad scope. It aims to protect the rights of all rural populations including peasants, agricultural and rural workers and indigenous peoples, and address the challenges they face. It recognizes the contribution of peasants to sustainable development, food security and biodiversity conservation as the basis of food and agricultural production, as well as their special relation with the land, water and nature. It specifically recognizes peasants' right to land and water, and the need to recognize their cultural identity and traditional knowledge. The Declaration, alongside the VGGT and the ITPGRFA, explicitly recognizes landscapes as the physical space that supports farmers' livelihoods and their continued contribution to food security and the conservation and sustainable use of agricultural biodiversity. In this context, the linkages between rights to land and natural resources and farmers' rights will be explored below, as part of the analysis of expressions of fair and equitable benefit-sharing.

\section{Land and international investment law}

While land and natural resources are obviously covered by the principle of national sovereignty, an ever-increasing network of multilateral and bilateral investment treaties aim at protecting foreign investment established mainly in developing countries, and may come into play in the case of large-scale agricultural investments. Lack of transparency makes it difficult to know which land deals exactly are covered by investment treaties; however, after a study of available data, Lorenzo Cotula and Thierry Berger have concluded that $64 \%$ of land deals were protected by at least one investment treaty (Cotula and Berger 2015). At the same time, Cotula (2016) draws attention to the 'highly dynamic process' of development of international investment law, characterized by multiple bilateral treaty negotiations and an increasing arbitral jurisprudence. 
International investment law sets substantive and procedural standards for the protection of investment against regulatory action of the host state. With regard to land governance, it may come to the fore both with regard to the allocation of property, thus the conditions under which investors acquire land and resource rights, and its protection (Cotula 2016). No investment arbitration tribunal has directly addressed large-scale land acquisitions to date, although the possibility cannot be ruled out. With an ever-expanding field of application, over the years investors have challenged public measures to claim protection for their assets in areas ranging from landownership to shareholdings, with monetary compensation being the most common remedy for breaches of investment treaties.

While according to the mainstream economic paradigm foreign investment can contribute to economic growth and development, the conditions required for the host country to benefit from such investment, and the extent to which international investment agreements enable such conditions, are still open to debate (Tauli-Corpuz 2016). Three legal considerations are of particular relevance: the lack of references to human rights obligations in investment agreements; the fear of dispute settlement arbitration, which may restrict the host state's regulatory activity for the public interest; and the lack of public participation in drafting, particularly with regard to the groups that are affected the most, as is the case of indigenous peoples and rural communities in land deals. It is remarkable that investment arbitration tribunals routinely dismiss human rights considerations as falling outside the scope of their mandate (Tauli-Corpuz 2016).

In addition, according to Cotula (2016), the application of two legal concepts may be of particular risk to local land rights: the growing use of "preestablishment' obligations in investment treaties and the concept of legitimate expectations in arbitral jurisprudence. Pre-establishment national treatment clauses could require states to remove clauses that differentiate between foreign investors and their own nationals when it comes to land acquisition rights. While several investment treaties exclude land tenure from the application of pre-establishment rules, others do not (Cotula 2016). The concept of legitimate expectations, on the other hand, has been developed in arbitral jurisprudence as an implementation element of the treaty standard of fair and equitable treatment, and has been applied to challenge a wide range of public measures, including sanctions of contractual breaches, environmental regulations or tax legislation (Cotula 2016; Bernasconi-Osterwalder et al. 2012).

In theory, both international investment and international human rights law should govern the decisions and practices of the host state with regard to the rights and obligations of investors, the perceived benefits for the host state and the impact of the investment on the rights of affected local communities, such as indigenous peoples and rural populations. The expanding sphere of application of international investment law, in combination with its enforcement potential and the asymmetry in capacities and power of the parties involved, has resulted in protection of the international capital, often to the detriment of national development priorities in developing countries, restricting states' ability to regulate for the public interest. As detailed below, lack of recognition 
of customary tenure systems and rights may enable arbitrary expropriations to make land available for investment, increasing the risk of dispossession for vulnerable rural populations. Imbalances in the law raise questions about whose rights are being prioritized and why.

The troubled relationship between investment and human rights has attracted the attention of human rights bodies, including the Sub-Commission on the Promotion and Protection of Human Rights. The High Commissioner for Human Rights issued a report, including areas for consideration on the need to balance competing objectives related to seeking higher investment levels while pursuing national development objectives (UN High Commissioner for Human Rights 2003). Among them, states should consider: including the promotion and protection of human rights among the objectives of investment agreements; ensuring their right and duty to regulate; promoting investors' obligations, alongside their rights; and promoting international cooperation as part of investment liberalization, including with regarding to funding commitments for international development.

While such recommendations require a total rethinking of international investment treaties, implementation also requires social transformations. Victoria Tauli-Corpuz, UN Special Rapporteur on the Rights of Indigenous Peoples, has highlighted the 'implementation gap' resulting from the power imbalance between political elites and vulnerable populations, even in countries where human rights standards have been incorporated into national law, explaining that 'deep-rooted structural discrimination and vested interests can render ineffective the legal protections' (Tauli-Corpuz 2016: 6). That said, many of the challenges associated with the implementation of international investment agreements have been raised in the context of intergovernmental deliberations on a treaty on business and human rights, briefly addressed below.

\section{The emergence of benefit-sharing in land governance}

As noted above, emergence of the concept of fair and equitable benefit-sharing in land governance cannot be clearly traced as part of an evolutionary line. References to benefit-sharing seem to be more ad hoc, although still linked to notions of justice and solidarity to the vulnerable. Its legal bearing is not consistent. In the context of the instruments and jurisprudence presented in the previous section, benefit-sharing is sometimes framed as a right, other times as a policy objective, and yet other times as a safeguard. The relation of benefit-sharing with tenure rights is also not clear. The section below presents some illustrations.

Following the detailed exploration of benefit-sharing in agricultural research and development in the first chapter, it comes as no surprise that the strongest references to benefit-sharing as a right are linked to the utilization of traditional and local knowledge for research and/or development purposes. The clearest illustration in this regard is the conceptualization of benefit-sharing under farmers' rights in the ITPGRFA context, which will be examined in detail in the following section. 
Environmental treaties and the VGGT see benefit-sharing from natural resource use, including land use, as a policy objective to be implemented at the intra-state level, so within a national territory. They seek to create a framework involving the enabling conditions and decision-making capacity for both the identification and realization of benefits at the local level, and the sharing of such benefits. Such a framework would thus entail both procedural and substantive elements. The identification and sharing of benefits, in such cases, would usually also involve assessment of the risk and burdens, and potential conflicts regarding resource use. Actors involved would include the state or central government, one or more communities in the broad sense outlined above, and a company or investor, if applicable. A legal relationship (regulatory or contractual) would thus need to be established among the state and a community. Unlike genetic resource utilization, however, specific guidance is lacking, and only dispersed elements can be found in the adopted decisions. Well-established legal tools, such as environmental impact assessments, can be used for such purposes.

\section{Environmental treaties: $C B D$ and UNCCD}

The CBD, in which fair and equitable benefit-sharing features prominently among its three objectives, calls on parties to encourage the equitable sharing of the benefits arising from the utilization of traditional knowledge of indigenous and local communities as part of measures to support biodiversity conservation in situ (Art. 8(j)). This provision has been used as a cross-cutting theme throughout the development of intergovernmental guidance for CBD implementation (Morgera and Tsioumani 2010), also in relation to land tenure security, as noted above. The ecosystem approach (COP Decisions V/6 and VII/11), a CBD-endorsed strategy for the integrated management of land, water and living resources that promotes conservation and sustainable use in an equitable way, also offers useful elements for implementation of benefit-sharing in natural resource use (Morgera 2017; De Lucia 2019). The decisions on the ecosystem approach point to benefit-sharing as a reward for the integration of traditional knowledge in planning and management, and for ecosystem stewardship of indigenous peoples and local communities, and as an element of good governance. For instance, Principle 1 of the ecosystem approach (COP Decision VII/11) notes that indigenous peoples and other local communities living on the land are important stakeholders and their rights and interests should be recognized, while ecosystems should be managed for their intrinsic values and for the tangible or intangible benefits for humans, in a fair and equitable way. With regard to ecosystem management in an economic context (Principle 4), which is relevant for agricultural or other land uses, it is noted that, where those who control land uses do not receive benefits from maintaining natural ecosystems and processes, they are likely to initiate unsustainable land-use practices, from which they will benefit directly in the short term, while equitable sharing of the benefits of conservation can counter such challenges. Finally, as 
part of good governance, it is noted that accountability for making decisions needs to be placed at the appropriate level, including the central and local governments and community organizations. Strategic land-use planning and management decisions, for example, may be taken by the central government, operational decisions may be taken by the local government, whereas decisions associated with benefit-sharing may be taken by a community organization.

While the ecosystem approach's frame of action for decentralized decisionmaking is certainly intuitive, its implementation is not without challenges (Grindle 2007) and it does not rule out local opposition to a decision taken by the central government in the name of public interest, particularly if significant risks and costs are expected to impact the local level. This is often the case when it comes to large-scale agricultural investments, addressed below. In addition, a crucial question concerning implementation of benefit-sharing from natural resource use, including land, is its relationship with actual access to the resource. As noted above, replacing land-related rights with a share of benefits, which empirical research has shown tend to be monetary, fails to consider the broader benefits that people get from natural resources and at the end reproduces injustices, also by imposing dominant ideological, economic and development models (Martin et al. 2014; Dahlberg et al. 2010).

Other examples from the CBD context document the emergence of benefitsharing in land governance as an extension of biodiversity governance, with a focus on its enabling conditions. The programme of work on dry and sub-humid lands (COP Decision V/23) calls for promoting responsible resource management at the appropriate level through an enabling policy environment. Such a policy environment can be achieved, according to the decision, through strengthening local institutional structures for resource management, supporting indigenous and local techniques of resource use that enable biodiversity conservation and sustainable use and creating or strengthening appropriate institutions for land tenure and conflict resolution. Maintaining the socio-cultural diversity of indigenous and local communities is further endorsed as a goal for the programme of work (COP Decision VIII/2).

The above-mentioned Akwé: Kon guidelines aim to support the incorporation of cultural, environmental and social considerations related to indigenous peoples and local communities into new or existing impact assessment procedures, indicating that traditional legal tools such as impact assessments can be used to build the enabling conditions and allow for meaningful identification and sharing of benefits arising from an investment or development. Impact assessments can thus be used to identify and weight the expected cultural, social and environmental costs and impacts of proposed developments, as well as opportunities and potential benefits for the communities (Morgera and Tsioumani 2010). The guidelines specifically call for assessing the impacts of proposed developments on traditional systems of land tenure and other uses of natural resources, noting that developments that involve changes to traditional practices for food production, or the introduction of commercial cultivation and harvesting of a particular wild species, may lead to pressures to restructure 
traditional land tenure systems or expropriate land, as well as pressures on biodiversity (para. 47). The guidelines thus frame changes to traditional land tenure systems as potentially negative impacts that need to be assessed prior to a proposed development, with the argument that such changes can have farreaching ramifications, while the assessment should take into account the community's value systems. In addition, the baseline studies to determine the scope of impact assessments should address, among other areas, traditional systems of production and asset distribution, including ownership, land tenure arrangements and rights related to natural resources (para. 44). Interestingly, such rights and customary arrangements are framed as benefits. This shows that, in the context of land governance, the benefits are largely linked to decisionmaking capacity, i.e. who has the authority to make decision and thus maintains control over the actual resource, the land. This matter of control is also reflected in another provision, stating that indigenous and local communities should be involved in the financial auditing processes of the proposed developments, to ensure that the resources invested are used effectively (para. 46).

The guidelines provide examples of potential economic benefits, such as job creation within safe and hazard-free working environments, viable revenue from the levying of appropriate fees, access to markets and diversification of income opportunities. They clearly link such expected economic benefits with potential negative impacts, such as crime and sexually transmitted diseases (para. 40), implying directly that benefit-sharing requires first an assessment of costs and benefits. In a rare reference to intra-community benefit-sharing, they note that the impact assessment process should take into consideration the possible effects of a proposed development on the community by ensuring that particular individuals or groups are not unjustly advantaged or disadvantaged (para. 51).

The UNCCD also features several provisions on benefit-sharing from the use of local and traditional knowledge related to natural resource management in drylands (UNCCD Secretariat 2005). Recognizing the value of local and traditional knowledge for sustainable land management, it promotes its exchange, with appropriate return of the benefits derived from it to the local populations concerned, on an equitable basis and on mutually agreed terms (Art. 16). It further calls for its integration and validation in research and development processes, again ensuring that its owners will directly benefit from any commercial utilization or technological development derived from it (Art. 17) and it specifically acknowledges traditional knowledge with regard to technology transfer (Art. 18).

The UNCCD Strategic Plan and Framework 2008-2018 ${ }^{18}$ seemed to imply a form of benefit-sharing, linking livelihoods with benefits derived from income generated from sustainable land management. Under Strategic Objective 1, 'To improve the living conditions of affected populations', people living in areas affected by desertification/land degradation and drought were to have an improved and more diversified livelihood base and to benefit from income generated from sustainable land management (Expected Impact 1.1). This linkage, however, was not retained in the new UNCCD Strategic Framework 2018-2030. ${ }^{19}$ 
In the new framework, sustainable land management is linked to the generation of global environmental benefits related to biodiversity and climate (Strategic Objective 4), while improving the living conditions of populations affected by desertification, land degradation and drought is a separate objective (Strategic Objective 2).

Adopted 20 years later, in 2012, as the first comprehensive international instrument on land governance, the VGGT offer useful elements for the conceptualization and application of the concept of benefit-sharing in land use for food security and rural livelihoods purposes, with regard to distribution of benefits from state-owned land, including in the case of large-scale agricultural investments. Lack of clarity persists, however, on the relationship between benefit-sharing and tenure rights. These elements are explored in detail below as specific regulatory applications of benefit-sharing in land use, alongside farmers' rights.

\section{Status and applications of fair and equitable benefit- sharing in land governance}

\section{Farmers' rights}

The concept of farmers' rights, enshrined in the ITPGRFA and also discussed in international human rights processes, including the recently adopted UN Declaration on the Rights of Peasants, has a central role in the exploration and assessment of benefit-sharing in agriculture. This section will discuss the origin and rationale of farmers' rights, with a focus on farmers' right to benefit-sharing, its legal basis, implementation challenges and linkages with land rights, in an effort to construct a broad interpretation. A case study examines access to markets for smallholder farmers, a topic illustrating the interlinkages among benefit-sharing and its supporting elements and enabling conditions, including land rights, and highlights the need for a comprehensive analysis of complex governance frameworks.

\section{Origin and rationale}

The emergence of the legal concept of farmers' rights is a result of equity-, justice- and conservation-related considerations. Farming communities around the world have been developing crop varieties for centuries. Until recently, agricultural innovation was farmer-led, and depended upon farmers' seed exchange and crop management systems aiming to ensure both the conservation and development of agricultural biodiversity, and the sustainability and adaptability of production. Mainly as a subsistence strategy, farmers around the world have maintained a high genetic diversity of plants and animals, as well as different location-specific bodies of traditional knowledge and farming practices. Agricultural biodiversity is thus the outcome of interactions among the genetic resource (the seed), the environment (the surrounding ecosystem and 
natural resources) and farmers' management systems, practices and knowledge (Tsioumani et al. 2016).

Traditional crop varieties, serving as reservoirs of agricultural biodiversity, provide a much required safety valve in the face of threats such as pests, diseases and environmental stresses. With the primary emphasis being not on high yields and productivity, but on resilience and risk-adverse qualities in the face of harsh, variable and unpredictable conditions, they provide the raw material for modern scientific varieties, forming the basis of scientific plant breeding. As a result, they form the basis of local and global food security.

An increasing body of literature has been linking the loss of agricultural biodiversity to incidents of collapse of local agricultural production, food insecurity, social vulnerability and loss of livelihoods and cultural diversity (Thrupp 2000; Fraser 2003; Jacques and Racine Jacques 2012). Historical and current examples show that crop genetic uniformity, combined with specific socioeconomic conditions of either localized or global nature, 'invites disaster' (FAO 1993: 8). The Irish Potato Famine is one such example of dramatic proportions. Between 1845 and 1850, a potato blight triggered a famine that killed or displaced $25 \%$ of the Irish population, while at the same time food exports from Ireland increased (Kinealy 1997). A watershed in Irish history, the Great Famine still illustrates how agricultural management based on crop uniformity made the potato crop vulnerable to a pest outbreak, while a series of cultural, social and economic forces made the country's peasant population completely dependent on the potato (Fraser 2003). More recently, in the 1970s, genetic uniformity left the US maize crop vulnerable to a blight that reduced yields by $50 \%$ and destroyed almost US\$1 billion-worth of maize. At the same time, the grassystunt virus devastated rice fields from India to Indonesia, endangering the world's most important food crop. After a four-year screening of over 17,000 cultivated and wild rice samples, a gene providing disease resistance was found in a single wild rice population in Uttar Pradesh, India, enabling the development of the hybrids currently grown in Asia and confirming the value of wild crop relatives as source material of modern varieties (FAO 1993).

Uniform production is vulnerable not only to pests but also to market shocks. Fifty years after the Great Famine, the Greek raisin crisis, stemming from the collapse of raisin export markets, resulted in the loss of livelihoods for thousands of farmers and major riots, eventually driving the country's first migration wave of 1890-1910 (Aroni-Tsichli 2000). On the other hand, agricultural biodiversity and crop diversification is linked to not only environmental, but also socio-economic resilience (Elfstrand et al. 2011). Research by Bioversity International (2018), for instance, shows that planting different varieties of the same crop greatly reduces pest and disease damage, while forgotten and neglected varieties are increasingly being used to improve dietary diversity, health and nutrition as well as enhance livelihoods and food security through marketing of specialized products.

The value of agricultural biodiversity, however, resulting from the contributions of farming communities worldwide, is not adequately reflected in mainstream 
agricultural production. The modernization of agriculture and the green revolution dramatically increased world food production through scientific and technological advances, including modern plant breeding. The professionalization of breeding and the emergence of the commercial seed sector, however, promoted the uniformization of crop varieties, which resulted in the marginalization of customary farmer practices and varieties, and the erosion of agricultural biodiversity. The promotion of IPRs over crop varieties, examined in the first chapter, alongside insecure land tenure, and seed marketing and food safety regulations, explored below, have further marginalized, or in cases criminalized, customary farmer practices and informal seed systems.

The availability of high-quality seeds of different crops and varieties to suit farmers' needs is necessary to ensure sustainability of production and farmers' livelihoods. Smallholders in particular are involved in different seed systems in order to obtain or produce seed to fulfil their needs. According to the FAO (2018), these systems can be divided into two interlinked types: formal and informal or local ones.

Formal seed systems are similar throughout the world. They are clearly constructed and regulated systems involving a chain of activities, usually starting with plant breeding and selection, resulting in different types of varieties, including hybrids, and leading to variety certification and marketing. Their aim is to produce seed of optimal physical, physiological and sanitary quality, and to maintain the identity and purity of the variety. Seed marketing and distribution usually takes place through official outlets, although seed may also be distributed by research institutes. A central premise of the formal system is the clear distinction between 'seed' and 'grain' (Sperling et al. 2014).

Informal or local seed systems, on the other hand, tend to be locally organized and include most of the other ways in which farmers produce, access and exchange seed: from their own harvest, or from friends, family and local markets. In contrast to formal systems, varieties may be heterogeneous and the seed of variable quality and purity (Almekinders et al. 1994). There is not necessarily a distinction between 'seed' and 'grain', and seed selection and multiplication are usually integrated in the production process. Seed-related activities do not follow quality standards and regulations but are guided by local knowledge and social norms (McGuire 2008).

Extensive literature shows that informal seed systems are the most important source of food crop seeds for smallholders in developing countries, and that they should be supported as complementary to the formal one through an integrated approach in breeding, and seed production and distribution (Almekinders et al. 1994; Sperling et al. 2014). The importance of informal seed systems for farmers' livelihoods has been well documented around the world, including across Africa (McGuire and Sperling 2016), the Andes (Thiele 1999), Brazil (Santilli 2013) and Central America (Almekinders et al. 1994). This literature shows the role of informal seed systems in building ecological and socioeconomic resilience, promoting biodiversity conservation, supporting community cohesion and even sustaining peace in countries in fragile situations and 


\section{Benefit-sharing in land governance}

those affected by conflict (FAO 2018). Nevertheless, the current regulatory framework, fit for the formal seed sector, fails the informal seed systems by paying little attention to their special requirements and dynamic character. This regulatory framework includes not only the usually cited IPR framework, but also crop variety control systems, and seed certification and quality control regulations (Louwaars 2007), which limit in particular smallholders' access to seed markets, as explored below.

The concept of farmers' rights emerged partly as a response to this hostile regulatory framework. It was a reaction to the asymmetry between farmers as donors of germplasm in the form of traditional seeds and the producers of commercial varieties that ultimately rely on such germplasm. While commercial varieties were protected and generated returns on the basis of plant breeders' rights and other IPRs, there was no system of compensation, reward or incentive for the providers of the traditional germplasm. At the same time, farmers' rights were meant to ensure that the restrictions in use associated with IPRs would not adversely affect farmers' practices. That means that farmers should not only be allowed to continue, but also encouraged and supported in their contribution to the conservation and development of agricultural biodiversity and food security globally. Farmers' rights are therefore seen not only as a means towards equity but also as a crucial tool for conservation (Correa 2000).

\section{Legal basis}

Farmers' rights were first introduced into the International Undertaking on Plant Genetic Resources as an Agreed Interpretation of the Undertaking, adopted by FAO Resolution 4/89. In this Resolution, participating states recognized the 'enormous contribution that farmers of all regions have made to the conservation and development of plant genetic resources, which constitute the basis of plant production throughout the world, and which form the basis for the concept of Farmers' Rights'. In addition, Resolution 5/89 on farmers' rights introduced the element of benefit-sharing, acknowledging that 'farmers, especially those in developing countries, should benefit fully from the improved and increased use of the natural resources they have preserved'. Farmers' rights were recognized in the latter Resolution as arising from the past, present and future contributions of farmers in conserving, improving and making available plant genetic resources, particularly in the centres of origin/diversity. These rights were vested in the international community, as trustee for present and future generations of farmers, for the purpose of ensuring full benefits to farmers, and supporting the continuation of their contributions (Tsioumani 2014; Andersen 2005).

The issue of farmers' rights was debated intensely during the ITPGRFA negotiations and was eventually left to the responsibility of national governments. The Treaty acknowledges farmers' 'enormous contribution' to the conservation and development of plant genetic resources (Art. 9(1)) and obliges governments to assume responsibility for upholding them; it stops short, however, of actually defining farmers' rights. Rather, it sets out measures a party should take to 
protect and promote them, including: the protection of traditional knowledge; the right to equitably participate in sharing benefits arising from the utilization of plant genetic resources for food and agriculture; and the right to participate in decision-making at the national level on related matters (Art. 9(2)).

Interestingly enough, the Treaty reaches no final conclusion with regard to farmers' seed-related rights and their link to IPRs. Instead, it states that 'nothing in this Article shall be interpreted to limit any rights that farmers have to save, use, exchange and sell farm-saved seed/propagating material, subject to national law and as appropriate' (Art. 9(3)). It does not, therefore, limit the customary rights of farmers to reuse, exchange or sell farm-saved seeds. Nor does it safeguard these rights by establishing an international legal basis for their protection. To add to the confusion, the ITPGRFA preamble states that:

the rights recognized in this Treaty to save, use, exchange and sell farmsaved seed and other propagating material, and to participate in decisionmaking regarding, and in the fair and equitable sharing of the benefits arising from, the use of plant genetic resources for food and agriculture, are fundamental to the realization of farmers' rights, as well as the promotion of farmers' rights at national and international levels.

Although the preamble uses a positive formulation to refer to seed rights, a contextual interpretation would suggest that it refers to seed rights as and if protected at the national level. It is therefore difficult to argue that the ITPGRFA creates an international legal basis for implementation of farmers' seed-related rights in view of the shrinking exemptions to plant breeders' rights and patents examined in the first chapter. The Treaty provisions can, however, be used to justify national policies providing the necessary space for informal seed systems and for farm-saved seed exchanges as a means of supporting smallholders' livelihoods.

Additional arguments can be found in the 2010 Nagoya Protocol on ABS, adopted under the CBD, which sets out an obligation on parties not to restrict the customary use and exchange of genetic resources and associated traditional knowledge within and among indigenous peoples and local communities (Nagoya Protocol Art. 12(4)). This provision envisages that states should avoid placing restrictions on traditional use and exchanges within communities, particularly as long as such traditional use and exchange contribute to the conservation and sustainable use of biodiversity, and the fair and equitable sharing of benefits. The rationale is the recognition that, due to the inseparable nature of genetic resources and traditional knowledge for indigenous peoples and local communities, recognized in the Protocol's preamble, traditional use and exchanges of genetic resources are essential for the preservation and continued evolution of traditional knowledge, and for the preservation of communities' cultural identities. The provision thus represents an elaboration of the more general obligation under the CBD to 'protect and encourage customary use of biological resources in accordance with traditional cultural practices that 
are compatible with conservation or sustainable use requirements' (CBD Art. 10(c)); Glowka and Normand 2013). With a scope broader than PGRFA, it can be used to reinforce seed rights at the national level.

An international legal basis for the protection of seed-related farmers' rights may be emerging as a result of developments in the human rights realm (Berger and Tsioumani 2019). In his 2009 report to the UN General Assembly, Olivier De Schutter, Special Rapporteur on the Right to Food at the time, highlighted the interaction between farmers' rights, farmers' seed systems and the human right to food, pointing out that a human rights framework may assist states in addressing challenges related to agrobiodiversity conservation and the needs of smallholder farmers in the context of industrialized agriculture (De Schutter 2009). The right to adequate food has been affirmed in several international instruments, including the International Covenant on Economic, Social and Cultural Rights (ICESCR), which imposes on states three levels of obligations: respecting existing access to adequate food; protecting the right to food; and fulfilling the right to food (De Schutter 2009). The introduction of legislative or other measures creating obstacles to the reliance of farmers on informal seed systems, or the failure to regulate the activities of IPR holders, could deprive farmers from a means to achieve their livelihoods and could therefore violate these obligations. In addition, states should be proactive and take measures to 'improve methods of production, conservation and distribution of food by making full use of technical and scientific knowledge, by disseminating knowledge of the principles of nutrition and by developing or reforming agrarian systems in such a way as to achieve the most efficient development and utilization of natural resources' (Art. 11(2)(a)).

When it comes to the need for states to take a proactive approach to implementation, the normative content of the right to food has also been clarified in the 2004 Right to Food Guidelines, which call on states to promote agricultural research and development, 'in particular to promote basic food production with its positive effects on basic incomes and its benefits to small and women farmers, as well as poor consumers' (Guideline 8.4). It should be noted that the Right to Food Guidelines were the first international instrument to articulate explicitly the relationship between the right to food, land tenure and agricultural biodiversity including plant genetic resources. ${ }^{20}$ In particular, states should take measures to promote and protect land tenure security, especially with respect to women, and poor and disadvantaged segments of society, and consider establishing legal and policy mechanisms that advance land reform to enhance access to land for the poor and women, and promote land conservation and sustainable use (Guidelines 8.1 and 8.10). In addition, states should consider policies to prevent the erosion and ensure the conservation and sustainable use of genetic resources for food and agriculture, including through traditional knowledge protection, benefit-sharing and participation of farmers and local and indigenous communities in national decision-making on relevant matters (Guideline 8.12). Therefore, access to land and natural resources, to outcomes of agricultural research and development and to agricultural biodiversity including 
plant genetic resources for food and agriculture are considered in the Guidelines as means towards the realization of the right to food. The Guidelines further recognize protection of traditional knowledge, benefit-sharing and participation in decision-making processes as means for the conservation and sustainable use of agricultural biodiversity, although they do not refer to them as farmers' rights. Unfortunately, they offer no further guidance on the relationship between the right to food, land tenure and agricultural biodiversity including plant genetic resources, a relationship which remains little understood in international policymaking and understudied in academic scholarship. Continuing debates on the implementation of farmers' rights under the ITPGRFA, as well as the recently adopted UN Declaration on the Rights of Peasants, can provide opportunities for better understanding.

The UN Declaration on the Rights of Peasants constitutes a valuable addition to the international legal basis of farmers' rights, providing useful elements for their conceptualization and implementation. It clearly states that peasants and other people working in rural areas have the right to seeds, including the right to save, use, exchange and sell their farm-saved seed or propagating material, and the right to maintain, control, protect and develop their own seeds and traditional knowledge (Art. 19(1)(d) and 19(2)). These rights are accompanied by a range of obligations for states, including taking measures to respect, protect and fulfil the right to seeds, recognizing peasants' rights to rely on their own seeds and to decide on the crops they wish to grow, and supporting peasant seed systems (Art. 19(3), 19(5) and 19(6)). At the same time, other obligations for states address the relationship between agricultural research and development, seed policies and IPRs and peasants' needs and livelihoods. States must thus ensure the availability of sufficient and affordable quality seeds (Art. 19(4)), take measures to ensure that agricultural research and development integrates peasants' needs and invest in research that responds to their needs (Art. 19(7)) and ensure that seed policies, plant variety protection and other intellectual property laws, certification schemes and seed marketing laws respect and take into account peasants' rights, needs and realities (Art. 19(8)).

Development of the UN Declaration on the Rights of Peasants has been informed by the work of UN Special Rapporteurs, including former Rapporteur on the Right to Food Olivier De Schutter, who has elaborated on rights related to access to seeds, benefit-sharing, as well as the distribution of benefits of scientific progress in the agricultural context. Olivier De Schutter has noted that states' obligation to fulfil the right to food implies strengthening access to and utilization of resources and means to ensure people's livelihoods, including food security, and improving food production methods by making full use of technical and scientific knowledge, in accordance with the provisions of the ICESCR and the Right to Food Guidelines (ICESCR Arts 11(2)(a) and 15(1)(b) and Guideline 8.4). These obligations apply both to the regulation of the commercial seed system and to the preservation and enhancement of informal ones. He has further noted that human rights obligations imply that the commercial seed system needs to be regulated in order to ensure that farmers 
have access to inputs, including non-open-access seeds 'on reasonable conditions', and that innovations leading to improved varieties and resources benefit all farmers, including the most vulnerable and marginalized ones. It follows, at the same time, that states should ensure that informal, non-commercial seed systems can be developed and protected from interference and pressures imposed by the commercial seed sector (De Schutter 2009).

These considerations, along with the elements provided for in the UN Declaration on the Rights of Peasants, can provide useful guidance with regard to the implementation of farmers' rights as set out in the ITPGRFA. Such elements relate both to seed rights as explored above, and to rights to land and natural resource use, association, education and training, and development, addressed below. These elements may also be used to illuminate the right to benefit-sharing as provided for in ITPGRFA Article 9 on farmers' rights.

\section{Conceptualization}

When it comes to national-level implementation of farmers' right to benefitsharing, the Treaty provision on farmers' rights does not provide any specific guidance. A more systematic examination of relevant ITPGRFA provisions is necessary in this regard, with a view to determining which of the possible types of benefit-sharing are relevant, including facilitated access to plant genetic resources for food and agriculture, the exchange of information, access to and transfer of technology, capacity-building and the sharing of monetary and other benefits arising from commercialization (ITPGRFA Art. 13).

As detailed in the first chapter, benefit-sharing within the ITPGRFA framework is multilateral (supported by a multilateral fund), rather than bilateral (based on bilateral, contractual arrangements between providers of genetic resources and commercial users). In the same vein, farmers' rights are collective rights. Identifying specific individual farmers that develop varieties later utilized in commercial breeding would be virtually impossible in view of the continuous experimentation and exchanges among farmers and farmer communities. Thus, monetary and non-monetary benefits stemming from the Treaty's Multilateral System are to be shared with farmers, particularly in developing countries, through the projects funded by the ITPGRFA Benefit-sharing Fund.

I understand this multilateral approach to benefit-sharing as aiming both to reward and to enable farmers' contribution to the conservation and sustainable use of agricultural biodiversity and thus to sustainable agriculture and global food security, as global public goods. As part of farmers' rights, benefit-sharing appears to operate in two arguably distinct but interlinked forms. The first is the sharing of the benefits arising from the past and present contribution of farmers to the utilization of genetic resources for research and development purposes, and the possible commercialization of the resulting varieties or products. In this form of benefit-sharing, farmers are the beneficiaries, entitled to part of the monetary and non-monetary benefits arising from such research and development efforts. The second form relates to the benefits arising from 
the contributions of smallholder farmers, indigenous peoples and local communities as users and stewards of agricultural biodiversity on-farm. These benefits flow to humanity at large as global public goods, and may be considered as part of a set of rights, which would enable farmers' continued contribution to the stewardship of the resources in the future (Tsioumani 2014). Through this twin 'reward and enable' approach, benefit-sharing is linked to farmers' and peasants' rights in their broad sense.

This approach resonates with the findings of the first phase of the Farmers' Rights Project, a ten-year project carried out by the Fridtjof Nansen Institute. In these findings, Regine Andersen distinguishes two approaches to the understanding of farmers' rights: the ownership approach and the stewardship approach. The ownership approach refers to the right of farmers to be rewarded for genetic material obtained from their fields, which is used in commercial varieties and/or protected with IPRs, while the stewardship approach refers to the rights that farmers must be granted and the legal space created to enable them to continue as stewards of agricultural biodiversity (Andersen 2006). She notes that respondents to the project's questionnaire indicated preference for the stewardship approach, adding that the ownership approach could lead to a 'tragedy of the anticommons' - a term coined by Michael Heller to describe a situation where numerous rights holders of a single resource prevent others from using it, eventually obstructing socially desirable outcomes (Heller 1998). Mirroring Garrett Hardin's tragedy of the commons, where a resource is prematurely exhausted because no one has the right to exclude (Hardin 1968), the tragedy of the anticommons refers to a situation where too many parties hold a right to exclude with respect to a particular property or resource, meaning that several permissions must be obtained for use, due to overlapping ownership claims. The term has been used since to describe the failure to innovate due to competing patent claims (Heller and Eisenberg 1998).

Andersen further highlights the limited demand for farmers' varieties among commercial breeders, which would mean that few farmers would benefit, and difficulties to identify exactly which farmer should be rewarded because of farmers' sharing practices. These remarks indicate that the ownership approach envisages a bilateral model of benefit-sharing, rather than the multilateral model favoured by the ITPGRFA as better reflecting the specificities of the agricultural sector. As examined below, however, domestic implementing measures take various approaches and clear understanding seems to be lacking.

A multilateral approach to benefit-sharing in combination with the 'reward and enable' approach proposed above suggests that farmers should not only be rewarded in monetary terms for their contribution, but should also be supported to continue their practices, which contribute to the conservation of genetic diversity. Such an interpretation of farmers' rights, including the right to benefitsharing, would be in line with the Treaty provisions on conservation, exploration, collection, characterization, evaluation and documentation of plant genetic resources for food and agriculture (ITPGRFA Art. 5), which requires parties to promote or support farmers' and local communities' efforts to manage and 
conserve on-farm their plant genetic resources for food and agriculture (Argumedo et al. 2011). This provision should be read together with Article 6 on sustainable use, which calls for the development of legal and policy measures, including on promoting the expanded use of local and locally adapted crops, supporting the wider use of a diversity of varieties and species in on-farm management and reviewing regulations on variety release and seed distribution. Farmers' rights are therefore among the preconditions for the achievement of the Treaty's objectives concerning the conservation and sustainable use of plant genetic resources for food and agriculture, for sustainable agriculture and food security (ITPGRFA Art. 1). Additional guidance with regard to their implementation at the national and local levels would therefore support implementation of the Treaty's objectives. Expert groups on farmers' rights, and PGRFA conservation and sustainable use, recently established under the auspices of the Treaty, will be contributing to this direction.

In line with the above, secure land tenure is a necessary precondition for continuation of farmers' contribution and a core enabling condition for the implementation of farmers' rights. Land, along with other natural resources such as water, constitutes the necessary resource base for farmers' livelihoods and their continued contribution to agrobiodiversity conservation. As explored above, access to seeds, including traditional varieties and commercial seeds at reasonable prices, is another enabling condition. In addition, implementation of benefitsharing as an element of farmers' rights may also include supporting measures, such as legal recognition of customary agricultural practices, assistance in the organization of community-based structures such as cooperatives and local seed banks, training and collaboration activities between farmers and scientists or professional breeders and access to markets, as examined below.

\section{Implementation challenges}

When it comes to farmers' rights implementation, or lack thereof, two (very generalized) tendencies can be identified in the literature: a 'celebratory' one, highlighting success stories and best practices, thus pointing to positive examples of implementation of farmers' rights and implicitly highlighting the available legal space and the potential for mutual supportiveness between environment- and trade-related legal instruments, and a 'denunciatory' one, highlighting cases of violation of farmers' rights and implicitly or explicitly calling for more radical socio-economic change. These two tendencies are exemplified by the research outputs produced by the Farmers' Rights Project, on the one hand (Andersen and Winge 2013), and GRAIN, a non-profit organization focusing on smallholder farmers and social movements on the other (GRAIN 2019a, 2019b).

Both academic and grey literature have focused more on seed rights than other elements, including benefit-sharing, protection of traditional knowledge and participation in decision-making processes, or the enabling conditions and supporting measures identified above. The focus on seed rights can be attributed 
both to the role of seed for peasant autonomy and farmers' livelihoods, and to the symbolic character the seed has acquired in broader agrarian struggles for social justice. At the same time, the seeds and varieties developed by farmers are based on their traditional knowledge and may reflect the status of enabling conditions, including access to land, so vibrant farmer seed systems can be considered an indicator of traditional knowledge protection and of undisturbed access to supporting mechanisms identified above.

In the first chapter, I touched upon the varying legal patterns with regard to the implementation (or not) of seed rights in the context of IPR-related and human rights obligations, noting they range from the judicial declaration of the primacy of patent rights over the right of the physical owner of the seed to save and replant in North America (Monsanto Canada Inc. v. Schmeiser; Bowman v. Monsanto Co. $)^{21}$ to India's legislation establishing rights for farmers to save, use, exchange and sell farm-saved seed (Ragavan and O' Shields 2007; Winge et al. 2013; Peschard 2014). Comparative legal analyses of implementation are rare. This could be attributed to the highly technical nature of the implementing legislation and the interlinkages among issue areas including agriculture, trade and environment. Karine Peschard (2017) is an exception; building on Andersen's conceptualization of farmers' rights' implementation in the context of an ownership or a stewardship approach (addressed above), and on the basis of a literature review and interviews, she examines the legal framework and practical implementation of farmers' rights in India and Brazil, two megadiverse countries with a high percentage of smallholder farmers. She concludes that India promotes an ownership approach to farmers' rights, having established a comprehensive piece of legislation on farmers' and plant breeders' rights (2001 Act on Protection of Plant Varieties and Farmers' Rights), which protects the rights of farmers to save, use, exchange and sell farm-saved seed within a conventional IPR framework. She shows that, despite the progressive intentions and extensive rights granted, including the 'remarkable achievement' related to the unambiguous recognition of the right to 'save, use, sow, re-sow, exchange, share or sell seeds, including from protected varieties, as well as harvested materials', a decade of implementation had no significant impact on farmers' rights or agricultural biodiversity conservation on the ground. She highlights in particular challenges arising from the right for farmers to register their varieties in the same way as breeders. This results in an uneven playing field, in which farmers' varieties enter a system developed to meet the different needs and criteria of the commercial seed sector, ultimately contradicting the objective of biodiversity conservation. Brazil, on the other hand, she argues, leans towards a stewardship approach, although farmers' rights are addressed more as exceptions to plant breeders' rights. Similarly, according to the Brazilian Seed Act, farmer varieties are exempted from registration with the national registry, while their inclusion in public programmes of seed distribution and exchange is ensured. This was in line with the strategies of Brazilian farmers' organizations and activists, who opposed the introduction of property rights on farmer varieties or the creation of centralized registries for such varieties. 
It should be made clear that seed production and commercialization in all countries with formal seed systems around the globe are generally regulated by two separate sets of regulations, operating in parallel: the IPR system, and seed and variety certification and marketing regulations. There are regional and national variations. In North America, for instance, state involvement in seed markets is minimal; certification is voluntary and variety release is the responsibility of the seed company (Louwaars 2007). At the same time, companies' control of the market via IPRs, in particular patents, is strong, as addressed in the previous chapter, and patents are enforced through contracts and the judicial system. In Europe, on the other hand, seed certification and variety registration in official catalogues are part of the mandatory authorization process for entry in the seed market. The objective is to control varietal identity and purity, and seed health, so as to make only quality seed of varieties of proven value available to farmers (Louwaars 2007). At the same time, though, this has an impact on informal seed systems, and thus agrobiodiversity conservation and farmers' rights, by marginalizing farmers' varieties and hampering access to seed markets. Some countries have attempted to remedy this by establishing derogations for farmers' seeds and varieties, as in the case of Brazil, addressed above. In the EU, rules on 'conservation varieties' set different requirements for the recognition and inclusion of such varieties in national catalogues. Although they were specifically designed to soften the seed regulations that hindered the conservation and sustainable use of crop genetic diversity, they were criticized for remaining too restrictive (Andersen 2013).

In fact, the EU regulations make an interesting case study of the interlinkages between conservation and sustainable use of plant genetic resources, benefitsharing and access to seed markets. EU Directive 2008/62 on conservation varieties $^{22}$ provides that such varieties may be approved for cultivation and marketing even when they do not meet the general requirements for recognition of varieties and sale of seeds and propagating material set in the relevant general directives. ${ }^{23}$ The Directive sets different guidelines for seed production and marketing, and for the recognition and inclusion in national catalogues, for varieties which are naturally adapted to local and regional conditions and are threatened by genetic erosion, and are of interest for the conservation of plant genetic resources. So the scope of the Directive is quite narrow already, as conservation varieties need to be threatened by genetic erosion, in addition to being of interest for conservation and be adapted to local conditions (which could potentially apply to all farmers' varieties). Considering these terms apply and the variety in question is submitted for approval by the national authority, some exceptions to the general seed and variety-related requirements apply: while conservation varieties must meet the normal requirements of distinctness, uniformity and stability for approval, and must conform to the usual certification requirements, application of the uniformity requirement and of the requirement for minimum varietal purity may be more flexible. At the same time, however, there are several restrictions. The seed of conservation varieties may be produced only in their region of origin, and the varieties can only be cultivated 
and marketed there; the quantity of seed marketed should not exceed $0.5 \%$ of the seed of the same species cultivated in the country in one growing season or alternatively a quantity necessary to sow 100 hectares, while for certain species stricter provisions apply; seeds of conservation varieties may be marketed only by authorized seed shops in their region of origin. This list of requirements has justifiably given rise to criticism and doubts as to whether the Directive serves its objective of conservation and sustainable use of plant genetic resources; farmers need to go through a highly complicated approval process and, even if their seed is approved, they are still prohibited from selling it unless through an authorized seed shop in the region of origin.

Directive 2009/145 on vegetable landraces ${ }^{24}$ aims to facilitate the sale of seed with no intrinsic value to commercial producers, but which have been developed for growing under particular conditions. In addition to the general aim of protecting plant genetic resources, the particular interest of preserving these varieties, as stated in the Directive, lies in their ability to grow in particular climatic, soil or agronomical conditions. It addresses conservation varieties of vegetables according to the same definitions and criteria of Directive 2008/62 with regard to registration, marketing and certification requirements, although seed quantity restrictions are calculated differently, as well as vegetable varieties with no intrinsic value for commercial crop production, also known as 'amateur' varieties. The requirements for the amateur varieties are less restrictive than those established for conservation varieties; there are no geographic restrictions for their marketing related to their region of origin, and no need to showcase risk of genetic erosion. At the same time, though, amateur varieties' seeds can be sold in small packages only, so they are destined for gardeners rather than professional farmers (Andersen 2013; Spataro and Negri 2013).

In the EU setting, the interlinkages and trade-offs between conservation and sustainable use of agricultural biodiversity and farmers' rights, on the one hand, and agricultural productivity and marketing requirements, on the other, are partly illustrated by the Kokopelli case and related judgment of the European Court of Justice. ${ }^{25}$ The facts of the case, set in 2005, are as following: Kokopelli is a non-profit association which sells seed of traditional vegetable and flower varieties, without following the general registration and marketing requirements of the Directive on vegetable seeds. It is to be noted that the Directive on vegetable landraces did not exist at the time. Graines Baumaux, a seed trader, identified 461 varieties offered for sale by Kokopelli which did not follow the marketing requirements. Baumaux thus commenced proceedings on grounds of unfair competition, claiming damages of $€ 50,000$ and seeking the removal of all advertising for those varieties. At first instance, the court at Nancy, France, found that Kokopelli and Baumaux were competitors, as they were both operating in the sector of traditional or 'old' or 'collectors" seed, they were marketing 233 identical or similar varieties and they were supplying the same customers, amateur gardeners. It therefore considered that Kokopelli was engaging in acts of unfair competition by offering for sale vegetable seed which was neither in the French catalogue nor in the common catalogue of varieties of 
vegetable species. It thus awarded Baumaux damages of $€ 10,000$ and dismissed the remainder of the action. The court of appeal made a preliminary reference to the European Court of Justice asking whether a series of seed-related directives, including Council Directive 2002/55 on the marketing of vegetable seed and Commission Directive 2009/145 on vegetable landraces, are valid in the light of fundamental EU rights and principles, namely, the freedom to pursue an economic activity, proportionality, equal treatment or non-discrimination and the free movement of goods and also in the light of the commitments arising from the ITPGRFA, particularly insofar as they impose restrictions on the production and marketing of traditional seed and plants.

Needless to say the judicial procedures attracted a significant degree of attention from EU institutions, NGOs and farmer organizations and the seed industry (Bocci 2014). Advocate General Juliane Kokott delivered an opinion in favour of Kokopelli. While she noted that the ITPGRFA provisions cannot be used to challenge the validity of EU legislation on seed marketing, as they are not unconditional and sufficiently precise, she did conclude that the prohibition against the sale of seed of varieties that are not demonstrably distinct, stable and sufficiently uniform and, where appropriate, of satisfactory value for cultivation and use, established in the Directive on marketing of vegetable seed, is invalid, as it breaches the principle of proportionality, the free movement of goods, as well as the principle of equal treatment and the freedom to conduct a business under the Charter of Fundamental Rights of the EU. Particularly regarding the principle of proportionality, she stated that even following the adoption of the Directive on vegetable landraces which established derogations, the disadvantages for biodiversity remain disproportionate, while disadvantages for economic operators and consumers who wish to access traditional varieties are 'manifestly disproportionate' to the objectives of the prohibition, including productivity and the protection of farmers.

The Court, however, did not follow the Advocate General's opinion. It found that an acceptance regime based on the requirement that the seed of vegetable varieties is distinct, stable and uniform serves the objectives of increased agricultural productivity and establishment of the internal seed market, while the derogating acceptance regime for landraces guarantees the conservation of plant genetic resources. It further noted that a regime requiring prior acceptance, including the prohibition of sale of unapproved seed, is appropriate in light of the objectives pursued, and a less restrictive measure, such as labelling, would not be as effective since it would allow the sale of seed that is 'potentially harmful or not conducive to optimum agricultural production'. Therefore, the Court concluded, the EU legislature did not breach the principle of proportionality (or any of the other general principles the Advocate General invoked).

While a detailed analysis of EU law and this particular judgment falls outside the scope of this endeavour, a series of observations can be made to link this particular case to the issue areas addressed and my overall narrative. First, Kokopelli was convicted of unfair competition, not of its involvement in informal seed systems altogether (Bocci 2014). The specific issue at stake was 
the fact that Kokopelli marketed traditional seeds without following the legal requirements. While sale is certainly linked to the viability of informal seed systems, particularly given the trend of reducing public funding for agricultural research, the two do not necessarily coincide. Second, the EU legislation seems to consider European farmers as consumers of seed, potentially in need of protection in a traditionally fraudulent market managing a fragile product. While this may certainly be true for at least a proportion of farmers, it fails to provide for those farmers who continue to conserve and develop crop genetic resources on-farm. This failure to provide for on-farm, user-based innovation gives implicit prominence to ex situ conservation of plant genetic resources. As pointed out by Guy Kastler and Anne-Charlotte Moÿ (2013), to allow on-farm management of crop genetic resources for conservation purposes, "the EU should shelve its directives for conservation varieties and ... allow for more flexible variety lists. It should accommodate local varieties that are characterized by being populations and therefore are less stable and less uniform'. The reference to the criteria of stability and uniformity leads to the third observation. As highlighted by Riccardo Bocci (2014), the EU legislation, and the Court in its argumentation, 'seems to make objectionable claims about what agricultural progress is and what the strategies to increase productivity are'. By linking productivity solely to stability and uniformity, they ignore the value of diversity as key to the sustainability of such productivity, particularly in the face of climate change. In this context, non-uniform varieties with the potential to adapt to different environmental, agronomical and socio-economic contexts are needed, also with the objective of productivity in mind.

With regard to these challenges, and with the informal seed sector still thriving in France (Rezvani 2020), the recent French biodiversity and agriculture and food laws ${ }^{26}$ put forward a series of possible solutions attempting to balance objectives and priorities. The new biodiversity legislation would allow the transfer of seeds in the public domain, including farmers' traditional varieties, from non-profit associations to non-commercial users free of charge, with no requirement for inclusion in the national catalogue of varieties (Art. 11). The agriculture and food law would further allow the sale of such seeds (Art. 78). While strictly delineated, this solution would create an opening for the continued exchange of traditional seeds in the current context of industrialized and standardized agricultural production, and was hailed as a victory by relevant associations. To their dismay, however, application of both provisions was halted by the French Constitutional Council, which annulled them as unconstitutional due to procedural shortcomings (Réseau Semences Paysannes 2018). ${ }^{27}$ Denmark, on the other hand, has successfully legislated to allow the exchange and sale of 'non-commercial' seeds between family farmers and organizations, through an interpretation of 'marketing' under the EU directives. By arguing that the EU directives apply only to the marketing of seeds intended for commercial production, practices of exchange and sale of farmers' seeds not intended for commercial production were interpreted as not subject to the directives' requirements and limitations (Seed Freedom 2016). ${ }^{28}$ 
Still, while literature has focused more on the obstacles posed by IPRs, rather than by seed certification and marketing regulations affecting farmers' access to seed markets (addressed below), as understanding of these linkages is growing, this has started to change. After examining more than 40 domestic seed laws, Niels Louwaars (2007) has aptly explained that variety and seed regulatory and control frameworks in most countries are suited to the formal seed sector, but fail to pay attention to farmers' seed systems that are built on different principles and mechanisms and therefore have special requirements. He notes that variety control systems tend to limit the number of varieties available on the market and are not suited to identifying varieties appropriate for smallholders in ecologically diverse conditions, while seed certification and quality control regulations tend to restrict and consider illegal farmers' seed production and exchange systems. He therefore calls for explicit limitations in seed laws to allow for the development of diversified seed systems and for emphasis on supporting the production and use of good-quality seed in both the formal and farmers' seed systems rather than on policing the formal seed system (Louwaars 2007). Christine Frison (2018) has further addressed the matter, highlighting the need for political will to soften the seed certification and registration regulations and allow the flexibility suited to farmer varieties.

Domestic measures on benefit-sharing are difficult to conceptualize and identify. They may be considered to relate to projects funded under the Treaty's Benefit-sharing Fund (ITPGRFA Secretariat 2017) or other international or domestic programmes (Andersen and Winge 2013), and they may range from monetary support through domestic funds to enabling measures and supporting structures. This lack of clarity is reflected in the (limited) literature and points to the value of the work undertaken by Louisa Parks (2019) as part of the BeneLex project and the need for ongoing research on domestic and local understandings of benefit-sharing.

Among the examples identified in the literature, Peschard draws attention to the provisions on benefit-sharing in India's Act, which state that farmers who are engaged in the conservation of genetic resources and their improvement through selection are entitled to receive benefits through the National Gene Fund. Upon registering varieties, private and public breeders must declare if they have used genetic resources maintained by indigenous or farmers' communities. Indigenous and farmers' communities may also file claims to the National Gene Fund when they believe that genetic resources from their communities have been used without their authorization. However, she notes that the registration of farmers' varieties has not resulted in any instance of benefit-sharing yet, as no company has disclosed the use of a registered farmers' variety in the development of a commercial cultivar (Peschard 2017).

The ITPGRFA Secretariat, in its educational module on farmers' rights (2017), takes a broader approach to benefit-sharing, with a focus to projects funded under the Treaty's Benefit-sharing Fund and non-monetary benefitsharing. Among other examples, it mentions the biocultural protocol for access and benefit-sharing developed by the communities managing the Potato Park 
in Peru (explored in further detail in the fourth chapter), knowledge and technology dissemination by the Agronomic Research Center of the University of Costa Rica regarding potato varieties, including wild relatives, and establishment of participatory plant breeding programmes in India and Jordan that develop locally adapted varieties of wheat, barley, rice and maize while enhancing biodiversity use. The module further includes examples provided by the Farmers' Rights Project (Andersen and Winge 2013), including stories on the Seeds of Survival project in Mali, which works to combine scientific with traditional knowledge regarding the improvement of local crops, aiming to promote long-term food security for marginal farming communities, community seed fairs in Zimbabwe, which offer a venue for local farmers to display the crops they grow and interact with farmers and other stakeholders, and a project on the revitalization of cultivation of indigenous vegetable varieties promoted by the Hiroshima Prefecture in Japan and the Agricultural Gene Bank. The Farmers' Rights Project further showcases examples including participatory barley breeding in Syria, which combines farmers' knowledge with the knowledge of professional breeders, and benefit-sharing arising from a farmers' organization in a cooperative in Nepal, to improve the generation of benefits from production and better marketing. These case studies indicate that implementation of benefit-sharing as part of farmers' rights at the domestic and local level is inextricably linked to the remaining elements of farmers' rights, including supporting measures and enabling conditions, and far broader than monetary benefit-sharing, which is the main focus of international negotiations on benefit-sharing. This is also one of the conclusions of the BeneLex research on local-level expressions of benefitsharing that Louisa Parks (2019) explored, taking a broad, rights-based approach.

Parks (2019) analysed a series of original, local case studies, regarding traditional goat pastoralists on the isle of Ikaria, Greece, with questions related to access to land and access to markets (also addressed below), traditional health practitioners in Bushbuckridge, South Africa, with the discussion focusing on access to medicinal plants in a conservation context, Khwe residents of Bwabwata National Park, Namibia, with questions linked to wildlife management, residents around the Olaroz and Salinas Grandes salt flats, Argentina, concerning themes linked to lithium mining, and the Kelabit community of Bario, Malaysia, with questions arising on farmers' rice varieties and contract farming. Two of these case studies, the Greek and the Malaysian ones, are of particular relevance for this analysis, as directly related to agriculture and food production. Parks exactly highlights that the involved communities more often raised concerns linked to the conditions that need to be in place for discussions on benefit-sharing to begin and for the actual benefits to have a chance of being fair and equitable, with recognition being identified as a central theme, along with community organization, support from non-state actors, and procedural guarantees, in the context of complex governance structures. 


\section{Linking farmers' rights to land rights: constructing farmers' rights broadly}

Human rights considerations further support a broad interpretation of farmers' rights to include enabling and supporting measures as noted above, and could be used as guidance for domestic implementation efforts. The UN Declaration on the Rights of Peasants in particular puts forward a holistic approach encompassing human rights protected in other instruments and new standards for individual and collective rights (Claeys and Edelman 2019). The Declaration recognizes in its preamble the special relationship and interaction between peasants and the land, water and nature to which they are attached and on which they depend for their livelihood, as well as peasants' past, present and future contributions to development, and biodiversity conservation and improvement, as the basis of food and agricultural production and global food security, which are fundamental to attaining the internationally agreed goals, including the 2030 Agenda for Sustainable Development. Although its recent adoption does not allow for assessment of its potential to influence domestic implementation or human rights jurisprudence, its value lies in two main features: its comprehensive, substantive approach regarding the rights of rural populations, linking their vulnerabilities, their special relationship to land, water, seeds and natural resources, and their contribution to global food security, through rights already protected in international law and new ones; and the bottom-up process of its development and negotiation. These two features will be addressed below, with a focus on the provisions that illuminate potential implementation avenues for farmers' rights and their linkages to land and resource rights.

The Declaration includes provisions on 'traditional' civil and political rights, such as the right to life and the right of expression, often accompanied by more radically oriented elaborations. It also includes provisions on the so-called second-generation, socio-economic rights - such as the rights to work, freedom of association, education and training, and social insurance - and thirdgeneration, solidarity collective rights - such as the right to development and the right to the environment (Macklem 2015). Importantly, it includes a series of provisions elaborating on the right to land and to the sustainable use of natural resources.

A provision on the right to food (Art. 15), for instance, is accompanied by the right of peasants and other people working in rural areas to determine their own food and agriculture systems, which is recognized by many states as the right to food sovereignty (Art. 15(4)). 'Food sovereignty', a term coined by global peasant movement La Via Campesina at the World Food Summit in 1996, goes beyond food security, and refers to 'the right of peoples to healthy and culturally appropriate food produced through sustainable methods and their right to define their own food and agriculture systems'. ${ }^{29}$ La Via Campesina, which was instrumental in the development of the Declaration as addressed below, sees food sovereignty as a "process of building social movements and empowering peoples to organize their societies in ways that transcend the neoliberal vision of 
a world of commodities, markets and selfish economic actors' (European Coordination Via Campesina 2018).

A provision on the right to an adequate standard of living (Art. 16) further refers to the right of facilitated access to the means of production, including production tools and technical assistance, the right to engage freely in traditional ways of farming, fishing, livestock rearing and forestry and the right to develop community-based commercialization systems. As analysed above, a far-fetching provision details seed rights (Art. 19), while the provision on the right to health includes the right to use traditional medicines (Art. 23).

Other provisions are more radically oriented towards equitable resource use, such as: the right of equal access, use and management of land and natural resources, and equal or priority treatment in land and agrarian reform schemes (Art. 4(2)(h)); the right of access to and sustainable use of natural resources, and of participation in their management (Art. 5); and the right to water, for personal and domestic use, but also for livelihoods-related activities (Art. 21(1) and (2)). These are accompanied by environmental rights and relevant state obligations, such as: the right to the conservation and protection of the environment and the productive capacity of lands and resources (Art. 18); state obligations to ensure the conservation and sustainable use of biodiversity, protect relevant traditional knowledge and agro-ecological systems and prevent risks arising from living modified organisms (Art. 20); and state obligations to ensure access to water, including in customary and community-based water management systems, and protect water-related ecosystems (Art. 21(3) and (4)).

Other provisions develop interesting interlinkages, promoting ideas hardly explored in international law before. For instance, states facing high levels of rural poverty and in the absence of employment opportunities in other sectors shall take measures to promote sustainable food systems that are sufficiently labour-intensive to contribute to the creation of decent employment (Art. 13(4)).

Some of the provisions are particularly relevant as going beyond traditional approaches to create the enabling conditions for the enjoyment of all rights. These include participatory rights, such as: the right to participation in the preparation and implementation of development planning (Art. 4(2)(a)) and of policies and projects that may affect their lives, land and livelihoods (Art. 10); the right to organize associations and cooperatives (Art. 4(2)(e) and Art. 9); the right to information to promote empowerment (Art. 11); the right of access to justice and of legal assistance (Art. 12); and the right to education and training, including a state obligation to encourage equitable and participatory farmerscientist partnerships (Art. 25).

The Declaration includes a provision on guidance for its implementation by UN agencies and other intergovernmental organizations (Art. 27), which is of particular importance given the increasing role of such organizations in the design and implementation of development- and climate-related projects which could affect the livelihoods of rural populations. A final clause, partly inspired by the UN Declaration on the Rights of Indigenous Peoples, seeks to address the 
concept of limits to rights and the relationship, including potential conflicts, between rights and other policies. It states that any limitations to the exercise of rights provided for in the Declaration shall be non-discriminatory and necessary solely for the purpose of securing due recognition and respect for the rights and freedoms of others and for meeting the just and most compelling requirements of a democratic society (Art. 28).

Importantly, the Declaration asserts the right to land, individually and/or collectively (Art. 17), including the right to have access to, sustainably use and manage land and the water bodies, coastal seas, fisheries, pastures and forests, in addition to the right to housing (Art. 24). States are required to provide legal recognition for land tenure rights, including customary rights not currently protected by law, and recognize the existence of different models and systems (Art. 17(3)). In addition, states should consider carrying out agrarian reforms to facilitate broad and equitable access to land and other natural resources necessary to ensure that rural populations enjoy adequate living conditions, and to limit excessive concentration and control of land, taking into account its social function (Art. 17(6)). According to my knowledge, this is the first reference to the social function of land in an international instrument since the Declaration on Social Progress and Development of the UN General Assembly ${ }^{30}$ adopted in 1969 (times of profound social change) and thus represents an important novelty, particularly since social notions of property have been constantly challenged by free-trade agreements and commodification of land in a neoliberal context.

Thomas Ankersen and Thomas Ruppert (2006) offer an extensive review of the social function doctrine as a legal basis for land reform. Enshrined in several constitutions around the world, mainly in Latin America, or at a minimum incorporated into agrarian reform legislation and general property law, the social function doctrine suggests a greater role for the state in land policy for equity and social change than the traditional role of arbitration and regulation of private property relations. In this context, state protection of private property remains justified as far as property provides a 'social function'. Landowners are thus under the obligation to ensure that their property use serves a social function, or risk expropriation. Throughout the twentieth century, the social function doctrine has provided the legal basis for rural development and land restructuring policies for agrarian reform. Definition of this social function as 'productive use', however, served as a perverse incentive for massive deforestation in Latin America; landowners sought to clear and fence their land to demonstrate possession and ownership, before seeking title, further aggravating land concentration, and resulting in conflicts with 'unproductive' occupants such as indigenous peoples. The concept of social function was then gradually redefined, on the basis of environmental and human rights considerations, to accommodate other public interests such as the ecological function of property. As a result, possession and productive use of the land in many countries now includes land conservation, in addition to cultivation. Ankersen and Ruppert further highlight the example of Brazil, 
where the concept of social function has been broadened to include the 'socioenvironmental' function of land. This means that landowners should not only respect ecological functions but also promote respect for rural workers. In addition, the social function doctrine has been applied in an urban context in Brazil, suggesting that vacant buildings may be subject to expropriation for not fulfilling their social function.

Fundamental in private as well as public law in many countries, and with significant analytical potential with respect to the role of land in different societies and in the context of different philosophies, the social function doctrine has received little attention in international and comparative law scholarship. This reference in the Declaration could, however, incentivize further academic research, as well as use in international legal instruments and jurisprudence. While its application and underlying philosophy has the potential to contribute to equity and justice, it would still depend on who decides and for the benefit of whom, with issues related to the scale of actions and power of actors involved gaining importance.

When it comes to the process of development of the Declaration, Priscilla Claeys and Marc Edelman (2019: 1) characterize it as 'a new kind of people's diplomacy and an innovative, bottom-up process of building alliances, lobbying, and authoring international law'. In their study, based on their own involvement in the negotiations, interviews and insights shared by key actors, and a literature review, they argue that development of the Declaration represents 'a rare case of direct involvement of social movements in international law-making'. La Via Campesina had a leading role in the negotiations, from alliance-building and advocacy, to the sharing of information and analysis. Although some may find their account over-enthusiastic, it is undeniable that agrarian movements played a unique role in the negotiations, from the first call by La Via Campesina in 2001 for recognition of peasants' rights in debates on the right to development in the UN Human Rights Commission, to its adoption by the UN General Assembly on 17 December 2018. Indeed, as Claeys and Edelman put it (2019: 29), the adoption of the Declaration was a 'huge success', providing 'a glimpse of hope that multilateralism can be centred on human rights, anti-colonialism, justice and solidarity ... even in times of rising authoritarianism'.

Time will show whether the Declaration's emancipatory potential will become 'international common sense' (Edelman 2014) and be translated into pro-poor policy change on the ground, at times of multiple assaults on peasant livelihoods resulting from land-grabbing, industrialization of agriculture, trade liberalization, speculation in food commodities, dismantling of public support, discrimination and criminalization of activists. Despite its non-binding legal nature, the Declaration can inspire political mobilizations for democratic control over land; it can legitimize and provide political leverage to previously marginalized groups for legal change at the domestic level; it may influence power structures and relationships, in order to provide authority and legal guarantees in favour of people whose vulnerability results in making their rights insecure; it may also inform land restitution processes in cases of historic patterns of enclosure and 
dispossession (Franco et al. 2015). This can be particularly important not only with regard to implementation of farmers' rights, but also in the context of the global land rush, further addressed below.

Indeed, according to Noha Shawki (2014), claims by La Via Campesina eventually enshrined in the Declaration have resonated with international priorities, especially after the 2007-2008 global food crisis. At the same time however, she argues, peasant rights enjoy limited acceptance as norms by states, and domestic implementation is far from certain, particularly since they seek to expand internationally recognized human rights in ways that some states do not accept. In addition, besides such challenges, related to the current neoliberal paradigm, domestic implementation will have to address legal issues regarding transcribing the peasant identity in law, and defining adequately the rights holders while addressing the risk of excluding others.

The case study below attempts to exemplify the interlinkages among benefitsharing and other elements of farmers' rights, including supporting elements and enabling conditions, and highlight the need for a comprehensive analysis of complex governance frameworks. ${ }^{31}$

\section{Case study: benefit-sharing and access to markets for smallholder farmers}

Several policy fora have repeatedly identified the need for access to markets as an essential avenue towards improved livelihoods and development outcomes for smallholder farmers. At the same time, fora engaging in biodiversity conservation and sustainable use have linked access to markets to the concept of fair and equitable benefit-sharing. Despite the opportunities for cross-fertilization, there seems to be a disconnect between these two areas, however, and dialogue has been limited. In the analysis below, I showcase policy opportunities for promoting access to markets as an avenue for benefit-sharing, in order to enable farmers' continued contribution to agrobiodiversity conservation and sustainable agriculture, and achieve improved rural development outcomes. After recapping the discussion on access to markets in relation to farmers' rights under the ITPGRFA, and introducing the matter in relation to conservation and sustainable use of biodiversity under the CBD, I focus on the work of the UN Committee on World Food Security (CFS) as the forum offering the most possibilities to successfully address the interlinkages among all these agriculture-, environment- and development-related issues.

Smallholders are engaged in a variety of markets, both of agricultural produce and seeds, but informal local markets are easier for them to access. Few among them have access to more formal value chains or international markets. As noted already, they face various challenges in securing market access and eliciting benefits from markets due to a broad range of reasons, including lack of infrastructure, information and credit, and an inability to comply with marketing standards. Access to seed markets in particular is affected by IPRs and seed certification and marketing regulations, as detailed above. 
Research undertaken by the High Level Panel of Experts on Food Security and Nutrition (HLPE), which was established to provide the CFS with scientific and knowledge-based advice to underpin policy formulation, has suggested that strengthening smallholders' links to markets increases agricultural production, contributes to poverty reduction and improves food security and nutrition both for smallholders themselves and for urban and rural populations as a whole (HLPE 2013). Given radical changes in agri-food systems and technologies in the last two decades in the shape of extreme market concentration, it is necessary to examine not only how best to stimulate these linkages, but also to identify which markets are best to engage with, and under what conditions engagement is most likely to be beneficial and sustainable for smallholders (Wiggins et al. 2010). Furthermore, within an enabling institutional environment including secure access to markets, smallholders can contribute to the conservation and sustainable use of agricultural biodiversity and other natural resources while preserving traditional farming knowledge and techniques. In addition, in many countries smallholder agriculture functions as an important social safety net, both by providing potentially resilient food production in times of crisis and by being at the heart of social networks and solidarity systems. Overall, research demonstrates that smallholder farming can be an economically, socially and environmentally effective way of organizing agricultural production (HLPE 2013).

At the international level, access to markets is largely defined by international trade law, shaped by the WTO Agreement on Agriculture and the notoriously complex WTO negotiations, which tend to favour the interests of developed countries and large-scale agricultural producers against those of developing countries and smallholders (Rosset 2000). Still, bodies dealing with biodiversity, agriculture, food security and human rights have been striving to make an impact. The importance of well-functioning and regulated markets for the progressive realization of the right to food was acknowledged in the Right to Food Guidelines explored above, along with the realization that markets 'do not automatically result in everybody achieving a sufficient income' and cannot protect the environment and public goods (Guideline 4). The CFS has conducted policy work at the interface between smallholders, markets, and global and local food security. Discussions on farmers' rights under the ITPGRFA, as detailed above, touch upon access to markets in relation to the protection of agricultural traditional knowledge, benefit-sharing and seed rights, while under the CBD access to markets is mainly considered as an incentive measure to be used for the conservation and sustainable use of biodiversity, and fair and equitable benefit-sharing.

As analysed above, access to markets is not listed in the ITPGRFA as a tool for promoting farmers' rights. It can be considered, however, an enabling condition for their realization and the achievement of the Treaty's objectives on conservation and sustainable use of PGRFA, and fair and equitable benefitsharing. Obstacles are related both to IPRs and to marketing and certification requirements. 


\section{Benefit-sharing in land governance}

When it comes to the CBD framework, a number of instruments make reference to access to markets, generally as an incentive measure to ensure the conservation and sustainable use of biodiversity and the fair and equitable sharing of benefits arising from its use and management. The importance of economically and socially sound incentive measures for the conservation and sustainable use of biodiversity is explicitly acknowledged by the Convention (Art. 11). The Addis Ababa principles and guidelines for the sustainable use of biodiversity state that costs related to the management and conservation of biodiversity should be internalized within the area of management and reflected in the distribution of benefits from use. Economic incentives for managers who have internalized environmental costs include, among others, certification to access new markets (Practical Principle 13). On the contrary, the list of monetary and non-monetary benefits annexed to the Nagoya Protocol on Access and Benefit-Sharing includes no reference to access to markets. A reference to 'contribution to local economies' is included instead.

The 2000 CBD programme of work on incentive measures could serve as guidance on market-related topics. Unfortunately, intergovernmental deliberations on the item have been highly controversial, mainly due to linkages with trade liberalization and WTO negotiations on agricultural subsidies. As part of its review in 2008, the CBD Conference of the Parties established cooperation with the Biotrade Initiative of the UN Conference on Trade and Development to continue its work on trade promotion for biodiversity-based products produced in accordance with the three CBD objectives. Cooperation would address, among other measures, enhancing market access and promoting enabling environments (Decision IX/6, para. 13). Access to markets is also mentioned with regard to the impact assessment of proposed developments affecting natural resources. The Akwé: Kon guidelines on impact assessments, introduced above, specifically state that proposed developments should ensure that tangible benefits accrue to the communities involved, such as access to markets and the diversification of income opportunities (paras 40 and 46).

It is under the CFS that the most comprehensive work has taken place, including on obstacles, enabling conditions and policy recommendations to enhance access to markets for smallholders. The HLPE has observed a number of constraints to investing in smallholder agriculture, which include unfavourable market conditions and a lack of access to appropriate markets. It has noted that governance of agriculture and rural development needs to be designed so as to support the multifunctional roles of smallholder farming in development. Underscoring the importance of access to land and natural resources and public goods, it recommended that governments should prioritize linking smallholder farmers to all types of markets as well as promoting schemes that rely on smallholders for the procurement of food for school and institutional feeding programmes. It further drew attention to market failures and price volatility as major disincentives for smallholder investment and to the need for government intervention through regulatory instruments (HLPE 2013). 
Responding to these findings, the CFS Plenary adopted a set of policy recommendations on investing in smallholder agriculture for food security and nutrition, ${ }^{32}$ calling for particular attention to be paid to enabling smallholder farmers' access to productive assets and local, national and regional markets. Means proposed to enable access to markets for smallholders, while acknowledging the importance of non-monetary exchanges of products and services, included the development of distribution and marketing systems and mechanisms that are remunerative for smallholders and rural economies, the potential for smallholders to supply school and institutional feeding programmes and the promotion of cooperatives. The need to improve public policy instruments and institutions was also acknowledged, in relation, for instance, to contract farming and publicprivate partnerships. Public support is considered necessary for mitigating excessive price volatility, enabling smallholders to participate in the value chains of their choice, increasing their negotiating capacity and ensuring legal and fair business practices.

Building on these recommendations as well as the HLPE report, a HighLevel Forum on Connecting Smallholders to Markets convened in 2015. The Forum discussed good practices and lessons learned that illustrate the potential for smallholders to benefit from access to all forms of markets, including localized and informal markets, commercialized value chains and cross-border trade. A background report informing the discussions acknowledged the need for further work to 'unpack the complex relationship between smallholders, markets, and food security' but identified a number of findings on the basis of case studies (CFS 2016). Organizing in farmers' organizations or cooperatives was identified as essential to secure market access and compete with multinational firms, as well as to influence policy developments. Public policies favouring local sourcing for school meals have, for instance, proved highly beneficial for smallholders in many countries, including Ecuador, Brazil and India, and have improved food security and nutrition outcomes. Use of geographical indications, an intellectual property protection tool, has allowed producers to continue local production in traditional ways while receiving higher prices for their produce. Several challenges remain, however, including: a lack of data on informal markets and thus a lack of understanding of how best to support smallholder participation; building the capacities of smallholders to organize themselves and negotiate the terms of their contractual relationships; and developing a country-owned vision for agriculture at the national level addressing land governance, access to information and participatory research (CFS 2016).

Work continued, and the 2016 CFS Plenary endorsed a set of policy recommendations on connecting smallholders to markets. ${ }^{33}$ The recommendations range from addressing practical challenges, such as improving processing and storage facilities and smallholder-targeted infrastructure including irrigation systems and roads, to more general policy considerations touching on different areas of international law and policy, such as trade, innovation, environment, development and human rights. They call for acknowledgment of the key role 
smallholders play in the sustainable use and management of natural resources, the promotion of products with specific quality characteristics which increase income while preserving traditional practices and knowledge and agricultural biodiversity and the strengthening of smallholders' access to and control over productive assets and resources. They also recommend promoting South-South, North-South and triangular cooperation to improve smallholders' productivity and capacity to engage in all markets, and promoting food safety control systems that are appropriate for different scales, contexts and modes of production. Others refer to enabling conditions to reach markets, including access to market and price information, inclusive financial systems and enhancing smallholders' collective organization levels to increase their bargaining power. Institutional procurement programmes for public institutions, food assistance and school meals, where smallholders are linked to structured demand for food and agricultural products and where consumers can access smallholder-produced food, are mentioned as a specific tool for linking smallholders to markets. In this regard, Brazil's school feeding programme is often used to illustrate the potential of institutional procurement to serve development-related goals; the programme, which requires that $30 \%$ of school meal ingredients be sourced from local family farms, has helped reduce child hunger and malnutrition, but has also supported local agriculture and the country's smallholders, while promoting rural development and changing children's attitudes towards food (Sidaner et al. 2013).

The brief analysis above indicates that there are linkages among the concepts of access to markets and fair and equitable benefit-sharing, which, however, are not clear. Further systematization and conceptual clarification is needed to unpack them. Under the $\mathrm{CBD}$, access to markets is considered an incentive measure for conservation, sustainable use and benefit-sharing, but also as a potential benefit to be taken into account in impact assessments for proposed developments. For the realization of farmers' rights under the ITPGRFA, access to markets can be seen as an enabling condition for the protection of traditional knowledge and benefit-sharing, allowing farmers to continue contributing to the conservation of agricultural biodiversity and food security.

Against this background, the CFS has provided a relatively comprehensive framework for action, its mandate encompassing a wide range of issues related to food security and nutrition. While the concept of fair and equitable benefitsharing is not explicitly used, this work does illuminate potential policy tools and approaches, which could ensure that smallholders can access markets and benefit from them. It thus assists in operationalizing the benefit-sharing concept by shedding light on enabling conditions for fairness, equity, justice and redistribution, such as control over productive assets and resources, scientific cooperation, access to information and collective organization. The CFS is also well positioned, on the basis of both its mandate and policy outcomes, as well as its multi-stakeholder structure, to link to the High-Level Political Forum in order to provide input to the achievement of the Sustainable Development Goals (SDGs), in particular SDG 2 on ending hunger, achieving food security and 
improved nutrition and promoting sustainable agriculture. Under SDG 2, access to markets is listed as a means for doubling agricultural productivity and the incomes of small-scale food producers by 2030, while fair and equitable benefitsharing is mentioned in relation to the maintenance of the genetic diversity of seeds. Ongoing policy developments and related academic research may assist in further unpacking the relationship between the two, including in particular promoting models of agricultural development which consider genetic diversity to be a prerequisite of sustainable productivity, rather than an obstacle.

\section{Benefit-sharing from public lands}

Farmers' rights provide a preferential field for the study of benefit-sharing, as they are situated at the interface between the regulation of agricultural research and development in the form of user-based innovation, and land and human rights. Moving away from the law and policy of research and development and into land use and governance, references to benefit-sharing are scarce and less developed. Examination of benefit-sharing is thus inextricably linked to redistribution efforts for land or agrarian reform; the benefit to be shared is often the land itself or the right to use it. In addition, benefit-sharing considerations have been forwarded in the case of large-scale agricultural investments, although, as noted above, questions remain regarding the relationship between benefitsharing and land-use rights, particularly customary ones. That is, in many cases doubtful benefit-sharing arrangements seem to replace legitimate land-use rights, with detrimental effects for livelihoods and social cohesion.

\section{Public land governance: categorizations and challenges arising from customary rights}

While circumstances, terminology and categorizations differ greatly around the globe, in many countries public land refers to state-owned land either allocated for public use (such as roads and sea shores) or managed and transferred as a private asset (such as agricultural land). The degree and legal forms of state ownership or control of land vary depending on each country's socio-economic and legal system. The role of the state, however, remains crucial for land governance in several legal systems, as it is usually the central government that has the legal authority to allocate land (Cotula 2016). This is particularly important in the case of large-scale agricultural investments, explored below.

Public land is usually accompanied by systems of concessions or use rights, which regulate the way the state makes land, including agricultural land, available for use by individuals (Chouquer 2011; FAO 2015). Such systems may use various legal tools, depending on the legal tradition of each country, including, for instance, land concessions or lease agreements. Where state ownership of the land is not contested, such legal tools can be used to promote equitable use of land for food security and rural livelihoods objectives and can thus be considered mechanisms for benefit-sharing. As an illustration, the Greek legislation 
provides for granting use rights to public land to municipalities for the creation of vegetable food gardens, free of charge, and to individual farmers, farmer cooperatives and the unemployed for food production, for a low price. ${ }^{34}$

The same legal tools, however, can be used to deprive smallholders from their land-use rights, particularly in cases where land is used privately or collectively by individuals or communities, in accordance with customary tenure systems and on the basis of customary rights. In most countries, private property can be expropriated only if required for a public purpose and as long as its value is compensated. But in many countries, land tenure systems combine written laws and contracts alongside a range of customary rights and practices. This combination results in difficulties, because of the plurality of legal systems, rules and authorities with competence over land allocation and use. Customary rights may result being insecure, and land used by individuals or communities in accordance with customary tenure systems may at the end be considered public, because of lack of registration, legal recognition and formal title (HLPE 2011). Unless customary rights are recognized, land tenure insecurity may result in eviction, displacement or loss of livelihoods (Wily 2012).

Collective rights are particularly vulnerable, not only due to lack of recognition but also due to lack of understanding. This is still the case not only in developing but also in developed countries, as illustrated by the Ikarian case study below. In their extensive exploration of property rights regimes in the context of natural resource use, Elinor Ostrom and Charlotte Hess (2008) have addressed the confusion characterizing the debate in the legal and economic scholarship regarding the relative advantages of private and common property for the efficiency, equity and sustainability of natural resource use. Focusing on common terminological and conceptual problems, they define common property regimes in differentiation from open-access systems; whereas in open-access systems no one has the legal right to exclude anyone from using a resource, in common property regimes the members of a clearly demarcated group have a legal right to exclude non-members from using a resource. A second terminological problem concerns the automatic but wrong association between common property regimes and common-pool resources, when in reality common pool resources may be governed by any type of property regime (Ostrom and Hess 2008). In addition, community customary systems take various forms, often combining common property with highly differentiated customary tenure systems (Knight 2010; Guadagni 2002).

As Katie Sandwell and colleagues argue in their critical analysis of existing and evolving human rights frameworks in the rural context, human rights language and institutions, rooted in Western legal traditions, tend to prioritize individual and property rights over collective and use rights based on customary systems. In their words, such interpretations 'have been deployed in ways that do real violence to traditional customary systems and other existing social structures, clearing the path for neoliberal development and leaving communities less able to defend themselves against elite interests' (Sandwell et al. 2019: 9). Customary tenure arrangements were considered confusing and insecure, and many governments sought to replace them by formal and transferable titles, 
following the advice of international aid organizations, in order to attract foreign investment in the name of economic development.

Different types of land registration and titling programmes have been put into practice in many countries, with various priorities and aims, including to facilitate the creation of land markets, improve legal certainty in the face of developments, and promote investments in rural areas (HLPE 2011). The questions of preventing conflicts over land use and securing the customary rights of land users were integrated in several national agendas more recently (Merlet 2007; HLPE 2011) and have gradually attracted the attention of international organizations and scholars, particularly in the context of the latest wave of land-grabbing for international investment in farmland. Many governments have reviewed their land laws and policies, including constitutional amendments to ensure property rights for women, revised systems of land tenure administration, land right registration programmes and, in cases, greater recognition of customary rights and local land authorities (HLPE 2011).

The results of such efforts have been mixed, depending on the procedures, costs and accessibility of the process, as well as the vulnerabilities of land users. According to the literature and empirical case studies reviewed by the CFS High Level Panel of Experts on Food Security and Nutrition, long and costly processes risk excluding many users and giving rise to fraudulent claims, while lighter processes of registering family and/or collective rights through mapping and issue of certificates, even at the village level, may be more beneficial for the rural poor. At the same time, however, concerns have been reported that formal titles can accelerate landlessness, since poor farmers may be forced to sell their land to local elites or transfer it to investors after a bad harvest, for instance, leading to land concentration. Formal titles also tend to simplify the multiple claims and rights over land use, to the disadvantage of the often secondary rights of women or herders (HLPE 2011). Registration does not equal empowerment of local populations. Still, some sort of registration of customary rights helps to provide tenure security to rural people, and enables them to negotiate with either the government or a company in case of a proposed investment.

Securing the tenure rights of farmers who do not own the land but depend on it for their livelihoods, including, for instance, tenants and sharecroppers, is another complex issue, which affects millions of people around the globe. Legislative and policy interventions depend upon legal traditions, while their success is also dependent upon the collective power of farmer organizations (Merlet 2007). In France, for instance, as Michel Merlet (2007) notes, the system affords considerable tenure security to tenant farmers and sharecroppers through guaranteed lasting land access for the farmer through written contracts, government-controlled land rent, specific procedures for dispute settlement and policy control to avoid land concentration.

This brief introduction to the range of individual or collective, formal or customary, often overlapping rights that come into play with regard to land management serves to illuminate the complexities and challenges regarding the 
use of public land, in the context of overarching policy objectives such as development, food security and environmental sustainability. The particularities of rural communities in comparison to urban populations, as aptly identified by Katie Sandwell and colleagues, further complicate the picture: despite their vast differences, rural communities are generally more dependent on land-based resources for their livelihoods, often have a cultural relationship with land and social relationships built around it and generally have more limited access to state services and judicial infrastructure (Sandwell et al. 2019).

\section{Large-scale agricultural investments}

Due to the particular characteristics of rural communities, large-scale investments in farmland are considered among the main factors threatening rural livelihoods, radically transforming not only customary tenure systems but also formally recognized ones. Large-scale land investments by both national and international corporations are one of the key trends that emerged out of the 2008 global food crisis (Cotula et al. 2009; Scoones et al. 2018). After losing confidence in global markets as a stable and reliable source of food for their national food security, some major food-importing countries have shown a growing interest in the acquisition or long-term lease of large portions of arable land in other countries, mostly in the developing world (De Schutter 2010, 2011). In addition, large-scale land investments have been linked to increased land speculation, as land becomes a reliable investment, and to the production or construction of commodities in the name of sustainability, such as biofuels and carbon credits (Vermeulen and Cotula 2010; Sandwell et al. 2019). In an overview of the policy and market forces that enabled agri-food companies to seek more direct control of agricultural production, Lorenzo Cotula (2016: 181-182) further mentions that 'increasingly stringent quality, safety, and traceability requirements in global supply chains have created incentives for companies directly to control farming activities, or to source supplies from few large producers', as well as the adoption of favourable policies aiming to promote such investments in many countries.

While this intensification of global capital is certainly not unique to rural areas, its impact can arguably be harder due to the dependence of rural populations on natural resources, escalating what David Harvey had already described as 'accumulation by dispossession' (Harvey 2003; Sandwell et al. 2019). The land rush is not a new phenomenon. Exploring the historical context of the most recent global wave of the land rush, Liz Wily sees it as yet another 'seismic shift in who owns and controls land, resources and production', which has historically followed economic crises and shifts in political power (Wily 2012). Wily draws a narrative of dispossession and defiance of customary, mainly collective, tenure systems, starting from feudal law enclosing the use of common land in Europe, to colonial laws awarding land ownership at the expense of local populations around the world, particularly in Africa, leading to the latest global land rush. According to Cotula, this latest wave of land 
acquisitions has reshaped 'relations among sovereign states, and between states, citizens, and businesses' in legal terms, but has also resulted in 'significant contestation at local, national, and international levels, with local-to-global alliances of affected people, social movements, and NGOs opposing the deals or seeking inclusion under better terms' (Cotula 2016: 181, 185).

Figures concerning the recent wave of large-scale land acquisitions are uncertain, mainly due to the pace and transnational character of developments, lack of transparency and contract disclosure and the low level of implementation. Evidence shows an increased number of land contracts for agribusiness investments from 2005 to 2011, with the trend subsiding later on (Cotula 2016; Deininger et al. 2011). With regard to hectares in question, Lorenzo Cotula (2016) cites Land Matrix, a widely used database, to state that the latest figures are smaller than earlier estimates; he notes that cross-checked deals went down from 70 million hectares worldwide in 2011 to 43 million hectares in 2016. Still, he highlights the limitations of a quantitative analysis; contracts may concern very large areas, placing disproportionate pressure on land and local land claims, or they are often concentrated in specific regions, while figures fail to provide insights on the implications of each specific contract in its national and local context.

Parties to each contract and the legal form of transaction vary, depending on the national legal context. Land deals usually involve long-term concessions or leases, rather than purchases. The government of the host country is often directly involved in cases where land is owned or controlled by the state, although the involvement of local authorities varies depending on the national legal system, and customary chiefs or private individuals have also led land deals (Cotula 2016).

FAO has identified three key legal interventions for equitable and sustainable agricultural investments that can contribute to food security and rural livelihoods: securing the land rights of indigenous peoples and local communities; ensuring enforceable and meaningful benefits both for the country providing land as a whole, and the local community in particular; and guaranteeing the meaningful participation of local communities in the decisions and projects affecting them (FAO 2011).

Two issues are of particular relevance for the study and conceptualization of fair and equitable benefit-sharing in the case of large-scale agricultural investments: the potential mismatch between macro-level benefits at the government level and negative impacts on local-level livelihoods, resulting in unfair distribution of risks and benefits; and procedural shortcomings in the design and implementation of such agreements, due to a series of structural considerations related to national frameworks characterized by poor governance. These are explored below, in turn.

While foreign investment may contribute to economic growth and development if carefully designed, this contribution is generally measured at the national government level, translated, for instance, into GDP growth and improved government revenues. Expected local-level benefits usually include employment opportunities and infrastructure development, though, as Cotula 
and colleagues conclude in a 2009 study of specific land deals, 'these commitments tend to lack teeth' (Cotula et al. 2009: 7) due to legal challenges, including poor contract design and lack of enforcement of investor obligations, procedural shortcomings and power asymmetries, including imposition by sometimes corrupted - elites at the national and local levels (Knight 2010). As a result, rural populations may suffer the impacts of an agreement by losing access to their source of livelihoods, without enjoying any of the benefits. Importantly, lack of legal recognition may result in the 'invisibility' of customary tenure systems and disregard for local land-use rights in view of land deals, ending in well-documented dispossession and enforced relocation (Cotula et al. 2009).

Procedural shortcomings further contribute to the marginalization of local voices. Many countries do not have laws and policies in place to ensure the participation of local communities in land-related decision-making. Lack of consultation thus leads to top-down and poorly informed decision-making regarding identification of benefits, unfair distribution of costs and benefits and contestation of the investment on the ground. This involves risks for investor companies too, as unpopular land allocations can result in grassroots action, causing delays, higher costs or even termination of contracts (Cotula 2016). Even when local participation is required by law, the actual processes for community consultation are often unsatisfactory, due to failure to include all legitimate rights holders and lack of transparency in contract negotiations. Furthermore, involvement of local authorities does not always ensure fair participation. Often, local and customary authorities reinterpret customary land management rules and, in the context of weakened accountability mechanisms, make land available to developers for personal gain and to the detriment of weaker community members (Knight 2010).

In this context, benefit-sharing considerations can come into play as follows: as opportunities for meaningful participation and recognition of legitimate right holders in the decision-making process; in terms of safeguards for local land rights against arbitrary or unfair interference, to be included in the cost-benefit assessment process; and finally in the form of contractual arrangements for revenue-sharing and non-monetary benefits such as infrastructure development. Benefit-sharing thus relates to both its enabling conditions related to participation in the decision-making process, and the substantive outcomes. The concept needs to be understood and constructed broadly.

Reality on the ground, however, shows the limitations of the concept of benefit-sharing, even in the case of application of a broad construction as above. Even in the case of legitimate agreements, that is, agreements which have respected the national laws in question and are in accordance with international human rights standards, the question of who retains the decision-making authority remains. Such authority would generally rest with the central government, and is usually accompanied by a broad definition of public purpose requirements, which allows for expropriation against the will of land owners, let alone users, while compensation requirements are often inadequate and not 
accompanied by alternative livelihood opportunities. Imposition of a decision in the context of diverging views with regard to livelihood choices and aspirations and the preferred development model may result in grassroots contestation of the project, and further socio-economic and cultural marginalization of rural populations. While this is especially true for projects bearing particular burden for the environment and human health, such as extractive industries, imposition of the mainstream model of agricultural development which promotes largescale mechanized farming to the detriment of small-scale farmers may also have the same results. Such principled concerns regarding the impact of large-scale agricultural investments have not escaped the attention of critical literature. Opposing the argument that the challenges associated with large-scale agricultural investments may be fixed with regulatory solutions based on good governance, Olivier De Schutter, for instance, argues that they promote a type of farming which prioritizes export crops, increases vulnerability to price shocks, and accelerates development of land markets, with potentially devastating effects on local livelihoods (De Schutter 2011).

\section{An emerging legal basis for fair and equitable benefit-sharing from public lands}

Limitations acknowledged, the application of benefit-sharing considerations may be used to promote fair and equitable use of public lands as follows: through systems of concessions for the use of uncontested public land for food security and rural livelihoods objectives; and through procedural and substantive safeguards against arbitrary or unfair interference with local land rights, including in the case of large-scale agricultural investments. This conceptualization is supported by elements enshrined in the VGGT and other soft-law instruments, and illustrated by human rights jurisprudence, as explored below.

As a comprehensive instrument providing international guidance on land governance, the VGGT provide valuable insights regarding linking benefitsharing from land use with food security objectives, land rights and human rights in general. They establish general principles of responsible tenure governance, and provide specific guidance on legal recognition and allocation of tenure rights and duties, land restitution, redistributive reforms, administration of tenure and agricultural investments, among other issues.

A number of provisions address tenure allocation and governance, including the equitable distribution of benefits from state-owned land and the establishment of transparent, participatory and accessible mechanisms for the allocation of tenure rights, linking thus benefit-sharing with broader social, economic and environmental objectives (Art. 8). They seek to improve governance of tenure 'for the benefit of all, with an emphasis on vulnerable and marginalized people' (Art. 1(1)), linking therefore land tenure governance with poverty alleviation and giving general priority to the vulnerable among possible beneficiaries. As such, they become a tool not only for livelihoods but also for legal empowerment; the UN Commission on Legal Empowerment of the Poor 
has also highlighted the importance of secure land rights and equitable access to land for legal empowerment, noting they would improve livelihood security and contribute to sustainable poverty reduction and climate-resilient development (UN Commission on Legal Empowerment of the Poor 2008; UN SecretaryGeneral 2009).

The VGGT establish clearly (albeit broadly worded) a policy objective related to benefit-sharing from public lands, calling on states to "strive to develop policies that promote equitable distribution of benefits from State-owned land, fisheries and forests' (Art. 8(6)). This is supported by a series of substantive and procedural guarantees, including: recognition and respect of all legitimate tenure right holders and their rights (Arts 3(1)(1) and 5(3)); recognition of commonsrelated, collective land-use systems (Art. 8(3)); consistency with broader social, economic and environmental objectives, and due consideration of local communities that have traditionally used the land in the reallocation of tenure rights (Art. 8(7)); ensuring that allocation of tenure rights does not threaten the livelihoods of people by depriving them of their legitimate access to resources (Art. 8(7)); and development and implementation of participatory processes of tenure governance (Art. 4(10)).

Specifically for indigenous peoples and communities that 'exercise selfgovernance', the VGGT reflect the increased degree of protection that indigenous peoples have acquired in accordance with international human rights law. States should recognize their legitimate tenure rights to the ancestral lands on which they live (Art. 9(5)), ensure their full and effective participation in the development of tenure-related laws and policies (Art. 9(7)), including climate-related programmes (Art. 23(3)), and hold good-faith consultation before any project or measure affecting their resources, in order to obtain their free, prior and informed consent (Art. 9(9)).

As noted above, redistributive land or agrarian reforms can be considered a tool for benefit-sharing, aiming to share not only the benefits arising from the resource but also the resource itself. Land reforms have historically been used as a policy tool for social justice and rural livelihoods by promoting equitable access to land - although critical literature notes they often result in controversial changes serving the interests of national and local elites (Rosset et al. 2006; Scoones et al. 2018). The importance of such reforms, however, for the future of developing countries and social and economic justice, illustrated by struggles by peasants and indigenous peoples around the world for their right to land, has regained the attention of policy and academic circles in the recent decades. This is reflected in the provisions of the VGGT, explored below, as well as of the UN Peasants Declaration. The UN Peasants Declaration does not go into detail regarding process and safeguards. As noted above, however, it does highlight the objectives of agrarian reforms regarding facilitating broad and equitable access to land and other natural resources, and limiting excessive concentration and control of land, taking into account its social function, and prioritizes landless peasants, young people, small-scale fishers and other rural workers among potential beneficiaries (Art. 17(6)). 
The VGGT provisions address the objectives, rationale, tools, process, beneficiaries of redistributive reforms, as well as related safeguards (Art. 15). In recognition of the importance of such reforms for the broader national socioeconomic context, they call on states to 'seek to develop national consensus on proposed [tenure] reforms' (Art. 5(9)). Accordingly, the aim of 'broad and equitable access to land and inclusive rural development' can be facilitated by a series of tools, including the allocation of public land, voluntary and market-based mechanisms and the expropriation of private land for a public purpose (Art. 15(1)). Such reforms may be undertaken for social, economic and environmental reasons, and where a high degree of ownership concentration is combined with significant rural poverty (Art. 15(4)). They should be implemented through policies and laws with clearly defined objectives, exemptions and beneficiaries, developed through participatory processes and, if appropriate, following assessments on the potential positive and negative impacts on tenure rights, food security, livelihoods and the environment (Art. 15(5-7)). Beneficiaries may include families including those seeking home gardens, women, informal settlement residents, pastoralists, historically disadvantaged groups, marginalized groups, youth, indigenous peoples, gatherers and small-scale food producers (Art. 15(5)). In addition to access to land, beneficiaries should be provided with support services including technical assistance and access to credit and to markets (Art. 15(8)).

Implementation of this international guidance may require significantly developing or reforming domestic law. An open legal question, for instance, concerns the definition of 'legitimate' customary rights requiring protection under the VGGT; such rights may be socially recognized at the local level, but may lack legal recognition at the national level (Cotula 2016). In addition, implementation requires political choices. As Peter Rosset and his colleagues at the Land Research Action Network note (2006), the resurrection of land redistribution efforts in the 1990s is the outcome of two contending forces: the World Bank and rural social movements, including their association La Via Campesina. While the World Bank proposes market-based mechanisms for land distribution, meaning essentially privatization, rural social movements identify use of such mechanisms in the neoliberal context as part of the problem. Noting that market-based mechanisms legitimize chronic injustices and economic inequalities resulting in further land concentration, social movements call for an alternative development paradigm based on food sovereignty and fair and equitable access to land and natural resources. Among these contrasting forces, the FAO has been a central actor in implementation initiatives, often in partnership with others including the World Bank and civil society and social movements, and national governments. The FAO has also been active in the development of publications compiling and assessing experiences of national land reform initiatives, including the FAO Land Tenure Journal (Hall et al. 2016). For national governments the challenge remains to plan and implement fair and equitable land reforms to suit the particular local context, rather than follow ready-made, externally imposed solutions, the same conclusion that Doreen Warriner reached back in 1969. 
Accordingly, application of benefit-sharing from public lands as a policy objective varies around the globe. Academic and grey literature addresses various case studies, particularly in the context of implementation of the VGGT, offering a multidisciplinary rather than strictly legal analysis. Synthesizing many of the FAO publications as well as academic literature, Ruth Hall and colleagues illustrate how different actor groups have promoted and used the VGGT, the strategies pursued and partnerships established. Sierra Leone is identified as a largely successful case of tenure governance reform, facilitated through a trilateral G7 Land Partnership between the government, Germany and the FAO, which resulted in a national agreement on the priority areas for reform towards compliance with the VGGT, strong communication between key ministries in the country and improved relationships between the government and civil society (Hall et al. 2016).

In Latin America, the VGGT have found a receptive context, due to the region's history, constitutional traditions and the case law of the Inter-American Commission on Human Rights (Hall et al. 2016). In Brazil, a country with one of the highest levels of inequality of land distribution in the world, the VGGT held a central position in the country's narrative on family farming and agrarian reform, focusing on linking social and environmental development and a territorial approach based on autonomous development and the rights of indigenous peoples (Hall et al. 2016). Pursuant to its constitution, programmes have been developed to facilitate access to land for the landless through expropriation and redistribution of unproductive lands, settlement on public lands and tenure reforms. As land concentration continues unabated, policy developments are also shaped by the struggles of the Brazilian Landless Rural Workers' Movement (MST), one of the most active social movements in the region, known for its massive land occupations. The MST has launched the Popular Agrarian Reform, a new model of agrarian reform which links land distribution demands with governance based on food sovereignty and agro-ecology (Azevedo 2016). The country's land governance assessment by the World Bank (2014) acknowledged this influence and associated it with strengths of the land governance system related to increased guarantees of property rights, including of vulnerable groups, transparency in the allocation of public land and public accessibility of recorded land information. It is noted in particular that transfers of public land took place to land reform settlements and then to the landless, while social movements are directly involved in the granting of rural concessions and in urban land regularization.

As noted below, EU policy on land focuses on development cooperation with third countries rather than land governance challenges within the member states. However, land ownership concentration accelerates in Europe, reinforced by market dynamics and institutional rules, including the Common Agricultural Policy (CAP) (Gallico and Groppo 2016). This effect has been documented, despite the CAP's objectives related to ensuring the sustainable management of natural resources and achieving a balanced territorial development of rural economies and communities, to accompany the mainstream objective of agricultural 
competitiveness. In addition, concerns related to land-grabbing have been raised, particularly in Eastern Europe. According to the European Economic and Social Committee, agricultural land ownership is increasingly becoming concentrated and controlled by foreign capital, particularly in Romania, Hungary and Bulgaria, with detrimental effects for family farming, rural life and the environment due to the promotion of monocultures (European Economic and Social Committee 2015). The Committee concludes with calls for aid measures to make small-scale farming more sustainable and resilient, and for national policy measures implementing the VGGT.

Academic literature documenting and analysing country efforts to implement the VGGT provisions on benefit-sharing from public lands is limited. Leonardo Gallico and Paolo Groppo (2016) offer a rare glimpse into the specific experience of Italy, in particular Lazio Region and Rome Municipality; more than $25 \%$ of the region's agricultural land is owned by public institutions, with half of it being managed by local authorities and organizations as a commons. Aiming to enhance access to public land for young farmers, fostering new employment and economic opportunities and protecting the quality of the land, the region's Agency for Agricultural Development and Innovation issued a call for proposals for public land allocation. The call was the first such initiative since the national Land Agrarian Reform in the 1950s. As far as informal rights are concerned, Gallico and Groppo mention the case of the 'Agricoltura Nuova' cooperative farm, which occupied municipal land in 1977 and has been paying compensation fees to the Municipality of Rome since 1995. The farm has been benefiting from public funding despite lack of formal tenure recognition.

When it comes to procedural and substantive safeguards against arbitrary or unfair interference with local land rights, the VGGT provide guidance both on the protection of legitimate tenure rights, and on mechanisms for transparency, participation and accountability in decision-making regarding land allocation. Respect for legitimate tenure rights is considered a general principle of responsible tenure governance under the VGGT (Art. 3A) and is reflected in several provisions, including on safeguards (Art. 7), ownership and control of public lands (Art. 8), indigenous peoples and other communities with customary tenure systems (Art. 9), investments (Art. 12), restitution (Art. 14) and expropriation (Art. 16).

Particularly when it comes to investments, the VGGT require responsible investments to safeguard against dispossession of legitimate tenure right holders and environmental damage (Art. 12(4)), and provide safeguards to protect legitimate tenure rights, human rights, livelihoods, food security and the environment from risks that could arise from large-scale transactions in tenure rights (Art. 12(6)). Such safeguards, according to the VGGT, could include ceilings on permissible land transactions, promotion of production and investment models that do not result in the large-scale transfer of tenure rights to investors and partnerships with local tenure right holders. States should also consider conducting prior independent assessments on the potential positive and negative impacts of investments based on large-scale transactions of tenure rights, ensuring systematic and impartial identification of tenure rights (Art. 12(10)). 
Finally, states should ensure the protection of legitimate tenure rights when investing abroad (Art. 12(15)).

Additional substantive safeguards concern cases of expropriation. Expropriation should take place upon prompt and just compensation, and only if required for a public purpose, the concept of which should be clearly defined by law to allow for judicial review (Art. 16(1)). In general, state measures taken for public purposes should be determined by law, solely for the purpose of promoting general welfare, including environmental protection, and be consistent with human rights obligations (Art. 4(3)).

Procedural safeguards related to participation, transparency and accountability, along with equity and justice, are addressed in the VGGT as essential principles of implementation (Art. 3B) and integrated in several provisions. Recognition and allocation of tenure rights should follow a participatory consultation process, including indigenous peoples and other communities with customary tenure systems, smallholders and anyone else who could be affected (Art. 7(3)). Consistency with the principles of participation and consultation is also required when it comes to the development of policies covering the use and control of public lands (Art. 8(6)), any project or measure affecting resources held by indigenous peoples (Art. 9(9)), the development of rules on allowable transactions in tenure rights and the definition of large-scale transactions (Art. 12(5)), the conduct of investment assessments (Art. 12(10)), the development of laws and policies on redistributive reforms (Art. 15(6)), the planning and process for expropriation (Art. 16(2)) and the negotiation and implementation of mitigation and adaptation programmes (Art. 23(3)). Increasing transparency is required by several provisions, including as a means to prevent corruption (Arts 10(5) and 15(9)). Provisions on dispute resolution detail rules for access to justice, to increase accountability (Art. 21).

Among other soft-law instruments of relevance, the Principles on Responsible Investment in Agriculture and Food Systems (RAI), endorsed by the CFS in 2014 , focus on forms of investment and their impacts in broader terms than the VGGT. National-level implementation of the RAI Principles, however, is quite limited, partly because some stakeholders consider them as favouring the interests of the powerful rather than the vulnerable (Hall et al. 2016). Margherita Brunori (2015) has assessed the relevance of the RAI Principles for the study of benefit-sharing, concluding that they fail to mirror higher international standards. Instead, they seem to imply that investments generate benefits which will eventually be shared; the first paragraph highlights the role of responsible investment in agriculture and food systems for food security and nutrition, sustainable livelihoods, eradicating poverty and increasing economic growth, and therefore achieving sustainable development, among other objectives. A similarly vague reference concerns a requirement that contracts balance the interests of contracting parties and be based on their mutual benefit (para. 59). Interestingly, the only specific reference to benefit-sharing (leaving aside a reference to benefit-sharing from the use of genetic resources in accordance with international treaties) concerns the role of investments in fostering gender equality 
and women's empowerment (Principle 3) and therefore has an intra-community dimension; responsible investment should enhance women's participation in partnerships, decision-making, leadership and the equitable sharing of benefits. Accordingly, 'all stakeholders have a role in promoting gender equality and the economic empowerment of women to support their access to productive resources and to the benefits from agricultural investments' (para. 60). A series of other provisions refer to mechanisms, or enabling conditions, for benefitsharing: access to innovation and new technologies, for the empowerment of youth (Principle 4); promotion of the application and use of locally adapted and innovative technologies, including for smallholders (Principle 7); and impact assessments, to respect human rights and promote accountability (Principle 10). In general, however, they are worded in a broad, non-specific manner and seem oriented to the promotion of trade and investment rather than human rights and the protection of the vulnerable; their usefulness therefore for the conceptualization and operationalization of benefit-sharing is limited.

I should also mention the ongoing negotiations to develop a treaty on business and human rights, initiated in July 2015 in an intergovernmental Working Group on transnational corporations and other business enterprises with respect to human rights, under the auspices of the UN Human Rights Council. These negotiations were partly the result of the largely perceived as failed UN Guiding Principles on Business and Human Rights, endorsed by the Human Rights Council in 2011, ${ }^{35}$ a set of guidelines for states and companies aiming to prevent, address and remedy human rights abuses committed in business operations. The revised draft released in July $2019^{36}$ includes reference to measures to prevent human rights violations, integrating due diligence requirements and conducting human rights and environmental impact assessments and meaningful consultations with potentially impacted groups, but no mention of benefit-sharing or other redistribution-related terminology. A general preambular reference acknowledges instead that all business enterprises have the capacity to foster the achievement of sustainable development through increased productivity, inclusive economic growth and job creation.

When it comes to Europe, the 2004 EU Land Policy Guidelines, ${ }^{37}$ intended mainly for EU donors when supporting interventions in rural land policy and governance in developing countries, address many important areas of land governance, including land rights, redistributive reforms and linkages with other policy areas such as poverty reduction and the environment. Importantly, they recognize that access to land and natural resources is linked to the realization of many human rights. While these guidelines have received little attention, many of their elements regarding responsible land governance and secure access to land have been integrated in the 2017 New European Consensus on Development, ${ }^{38}$ which provides the framework for development cooperation in light of the 2030 Sustainable Development Agenda.

As noted above, the linkages among land tenure rights and several internationally recognized human rights have been acknowledged in the case law of regional human rights courts (Morgera 2019). The 2007 Saramaka decision of 
the Inter-American Court of Human Rights mentioned above is particularly relevant, as it involved a logging and mining concession by the government of Suriname on territory held by the Saramaka people, without their full and effective consultation. On the basis of international human rights law, the Court concluded that the Saramaka people, a tribal community of descendants of selfliberated African slaves, have a right to use the natural resources of their traditionally owned territory which are necessary for their survival. Linking the community's land rights to violation of the right to property under the American Convention on Human Rights, the Court declared that Suriname may grant concessions for the exploration of natural resources in their territory only when such concessions do not result in restrictions of the rights of the Saramaka people that would deny their physical and cultural survival. In particular, it should respect three safeguards: effective participation, and free, prior and informed consent with regard to investment projects with major impacts; sharing of the benefits derived from development plans; and prior and independent environmental and social impact assessment (Orellana 2008). Addressing jointly the safeguards of effective participation and benefit-sharing, the Court stressed that they 'are consistent with the observations of the Human Rights Committee, the text of several international instruments, and the practice in several States Parties to the Convention' (para. 130). As the reference to 'several international instruments' actually quotes provisions supporting the right to participation only, including of the ILO Convention no. 169 and the General Comment no. 23 of the UN Human Rights Committee (fn. 128), it can be argued that the Court considers the two tightly linked; participation is a key requirement for benefit-sharing, and identification and sharing of appropriate benefits could flow from effective participation processes. Similarly, when the Court addresses the safeguard of benefitsharing separately, it links it to the (narrower) right to compensation for loss of property under the American Convention on Human Rights (Art. 21(2)), noting the provision 'extends not only to the total deprivation of property title by way of expropriation by the State ... but also to the deprivation of the regular use and enjoyment of such property' (para. 138). It thus translates the right to just compensation into a right of the Saramaka people to reasonably share in the benefits made as a result of a restriction of their right to use and enjoy their traditional lands and natural resources. The Court finds support for this interpretation in provisions of the ILO Convention no. 169, a report of the UN Committee on the Elimination of Racial Discrimination ${ }^{39}$ and the reports of the UN Special Rapporteur on the rights of indigenous peoples. The limited, at the time, international legal basis supporting the safeguard on benefit-sharing from the use of land and natural resources underlines further the importance of the relevant provisions of the VGGT and the UN Peasants Declaration.

As an outcome of its argumentation, the Court ordered the government of Suriname, among other measures, to: delimit, demarcate and grant collective title over the territory of the members of the Saramaka people in accordance with their customary laws; grant the community with legal recognition of collective juridical capacity as a way to ensure the exercise of their right to 
communal property and collective access to justice; review relevant domestic and adopt necessary new legislation; and allocate the compensation amount set in a community development fund.

The Saramaka judgment has been part of a consistent line of jurisprudence under the Inter-American Court of Human Rights, and has inspired similarly or even more progressive developments under the African framework on human rights and global human rights processes (Morgera 2019). It is a landmark judgment for a series of reasons. It expands the international protection usually afforded to indigenous peoples to other communities, not identified as indigenous but maintaining an identity, socio-economic organization and livelihoods deeply associated with land and natural resources. It further identifies clearly the three interlinked safeguards for developments decided upon by the state on lands occupied by such communities, placing limits upon state powers and additional considerations for the identification of acceptable public purposes. It also acknowledges the need for legal arrangements to recognize communal property and communal management of natural resources. Finally, it has initiated a process of cross-fertilization between standards adopted under international human rights and environmental processes, with its reference to the CBD Akwé: Kon Guidelines on impact assessments, as noted above.

More than a decade later, however, compliance with the judgment remains problematic. This has been documented in three subsequent orders of the Court monitoring compliance with the judgment, issued in 2011, 2013 and 2018. In fact, while the state has established the community development fund in question and has paid in full the monetary damages in accordance with the judgment, it has failed to adopt a legislative framework providing for impact assessments of concessions, ensuring fair and equitable benefit-sharing and recognizing the community's effective participation in decision-making regarding concessions in their territory. Instead, the government continues to grant concessions in the Saramaka territory without their involvement (Rombouts et al. 2016; Koorndijk 2019). In addition, according to the 2018 order of the Court, ${ }^{40}$ the state has not yet provided adequate delimitation, demarcation and collective titling, nor has it provided the community with juridical personality. According to Koorndijk (2019), this is in line with findings in the literature that suggest that orders for monetary compensation have relatively high compliance rates, while states tend to avoid non-pecuniary reparations, due to structural considerations such as prevailing economic interests and marginalization of rights holders.

Documenting the state of compliance with human rights jurisprudence has been the focus of efforts by NGOs and social movements, such as the International Network for Economic, Social and Cultural Rights (ESCR-Net) and Cultural Survival, but has received little attention by international law scholars, possibly due to specialization-, discipline- and language-related barriers. Bas Rombouts and colleagues (2016) and Jeanice Koorndijk (2019) are among the exceptions. The limited literature illustrates the need to bridge the gap in legal commentary and provide a comprehensive picture of the socio-legal framework and its implementation on the ground, from the international to the national and 
the local level, creating partnerships with different disciplines. As explored also in the context of research and development above, this is particularly true for the concept of benefit-sharing, implementation of which is highly dependent on a combination of legal frameworks at different levels and of different areas of law, including private law when it comes to contractual obligations, as well as power asymmetries.

\section{Case study: land use and benefit-sharing on the isle of \\ Ikaria, Greece}

The case of the isle of Ikaria, Greece, involving pastoralism in the context of competing land uses and a multi-level governance framework, was one of the BeneLex local-level case studies, explored in detail by Louisa Parks (2019). As noted above, the case illustrates the interlinkages between benefit-sharing and access to land, access to markets and local livelihoods. ${ }^{41}$

Ikaria is a Greek island in the northeast Aegean Sea. Administratively, it belongs to the Periphery of North Aegean, the seat of which lies on the island of Lesvos. Ikaria is divided into three municipalities, the centres of which are located in the south, north and central-west parts of the island, respectively. As forested mountain Atheras crosses the entire length of the island, the road network and thus connectivity between villages has remained poor until now.

Ikaria maintains a relatively traditional economy combining agriculture and pastoralism with tourism activities, as well as a culture of self-organization and strong community ties, expressed through a communist political tradition and periodic community celebrations called paniyiries (Bareli 2018; Parks 2019; Bareli et al. 2020). Vineyards and a semi-wild goat population had been supporting this economy for centuries, and wine and goat meat have had a central role not only in food and nutrition but also in the island's unique culture and celebrations. Land-use management has historically been collective, organized around a complex customary system for the management of private, communal and village/municipal lands and the co-existence of crop cultivation and pastoralism. This system was built around: the common pasturelands of Atheras mountain, to which the inhabitants of neighbouring villages had a right of access; a network of fences collectively maintained by the villagers, which kept goats away from cultivated land; the periodically allowed use of private land as a common pastureland resulting in rotation in land use and thus ecological benefits; and the periodic movement of flocks from higher pasturelands in the summer to lower grazing land in the winter. Pastoralists were valuable members of this traditional society. On top of providing an important source of food and being at the centre of the island's culture, they were also respected for their knowledge of the land, the forest and the water sources.

The Greek independence from the Ottoman Empire and a series of subsequent laws regarding land ownership and administrative restructuring in the country resulted in abandonment of these customary rules. Following independence, the Greek state claimed ownership of most of the island's communal land, 
questioning the Ottoman titles held collectively by the villages. The legal status of communal land in Ikaria is still pending to date. Until final resolution, according to Greek legislation, ownership of this land rests with the state, but the villages retain tenure rights. The situation regarding land ownership and tenure rights has been further complicated by the fact that, following a series of administrative reforms, villages have seized to exist as administrative units and local administration has been centralized around municipalities. In addition, a 2015 law provided that the competence for the management of all grazing land would pass from the local to the regional administration, following the country's division into 13 administrative Peripheries. For Ikaria, this meant that decisions concerning the island's pastures would be made at the Periphery of North Aegean, based on the island of Lesvos (Bareli et al. 2020). This increases legal uncertainty regarding local tenure rights, and the Municipality of Ikaria is promoting an amendment to the national forest law for official recognition of such rights. For the time being, however, legal uncertainty and over-grazing as described below have resulted in pastoralists losing access to this land for grazing.

Within a context of a rising market economy and an increased tourism income, abandonment of customary land-use rules and the loss of legitimate access to pasturelands, an increase in the number of goats on the island resulted in over-grazing and environmental degradation, leading also to social conflict and marginalization of pastoralists. The increase of the goat population was due to the absence of natural predators on the island but also to policy-related factors. In the 1990s, direct payments under the CAP subsidized the number of animals, which led many Ikarian residents, in addition to farmers and pastoralists, to acquire animals. Following subsequent reforms of the CAP towards decoupling and cross-compliance, which changed the basis for payments and linked them to animal welfare and environmental considerations, non-professionals simply let the animals loose, which resulted in further environmental degradation. Compliance with specific requirements was generally lacking also on the part of professional farmers and pastoralists, due to pastoral traditions and circumstances on the island (for instance, the absence of barns), but also due to lack of information, irregularities in payments and lack of any self-organization on the part of pastoralists, whose association has been inactive for years. Combined with social conflict, this increased disempowerment and exclusion of pastoralists, particularly in the context of stricter application of CAP requirements following Greece's sovereign debt crisis. Cross-compliance was enforced through electronic data processing of all beneficiaries and animal tagging, the cost of which, however, was often prohibitive for small-scale producers. At the time of the last project visit to Ikaria in 2017, local employees of the Ministry of Agriculture remained pessimistic about bringing pastoralists into line with complex cross-compliance rules in time for them to maintain their subsidies.

In addition, implementation of EU regulations on food safety and animal welfare resulted in obstacles to slaughtering goats and thus reducing their 


\section{Benefit-sharing in land governance}

number. EU regulations on the slaughter of animals require killing in slaughterhouses that comply with stringent food safety, environmental and animal welfare rules. ${ }^{41}$ Only then does the meat get the stamp needed to be sold in the market. With no slaughterhouse on the island, pastoralists had two solutions: either transporting the animals to the nearest slaughterhouse (in Athens), which due to rules for the safe transport of animals ${ }^{42}$ implies prohibitive costs for small-scale producers, or taking advantage of legal derogations that allowed traditional slaughter methods ${ }^{43}$ when meat would be sold at the paniyiries of Ikaria. While the second solution was largely used, meat consumption at local paniyiries was not enough to curb the goat population, despite the increase of such festivities during summer, leaving pastoralists at a dead end.

The Ikarian case study is illustrative of the immense variety and complexity of land-use systems, and the diversity of factors that can influence them. It also shows the strong interlinkages between land-use rights and social conflict, the role of enabling conditions, including access to information and participation in decision-making, as well as smallholders' organization through associations or cooperatives, and the challenges for smallholders associated with access to markets in complex regulatory frameworks such as the EU. It further draws light on a series of questions regarding law development and implementation in such complex regulatory systems, and unintended consequences regarding livelihoods, social cohesion and environmental sustainability (Bareli et al. 2020); it also highlights the need for addressing the tensions associated with market and the local nature of agriculture, including its social and cultural aspects, and for developing specific policies to support smallholders, potentially balancing issues of scale, geography and livelihoods against stringent standards. ${ }^{44}$

\section{Concluding remarks}

In the preceding analysis, I mapped and assessed the emergence and applications of the concept of fair and equitable benefit-sharing in land governance, with a particular focus on farmers' rights and on the governance of public lands, including the case of large-scale agricultural investments. In contrast to the area of agricultural research and development, in which I traced the emergence and application of benefit-sharing as part of a clear evolutionary line reflected in legally binding treaties and linked to specific policy objectives and implementation mechanisms, references to benefit-sharing in the area of land governance are less developed, while the legal framing varies; while still linked to notions of justice and solidarity to the vulnerable, benefit-sharing is sometimes framed as a right, at other times as a policy objective and at yet other times as a safeguard, and its international legal basis is usually to be found in non-binding instruments.

There are fundamental elements that differentiate the regulation of benefitsharing from land use compared to benefit-sharing from genetic resource use for research and development. These elements relate to the nature of the resource, 
the scope of the regulation and the determination of beneficiaries. When it comes to the nature of the resource, land is fixed in supply, and policies are required to accommodate competing uses and overlapping claims. Restrictions in land use come from both material and legal limitations. Genetic resources, on the other hand, are renewable and easily multiplied, while restrictions in their use stem solely from legal limitations, such as IPRs and ABS laws. Furthermore, unlike benefit-sharing in research and development, which is an international law concept, land governance is still mostly a matter for domestic law. International law emerged relatively recently, mainly with regard to indigenous peoples' rights and human rights in general, environmental considerations and transnational investment. It was in the context of the 2008 global food crisis and the growing trend of large-scale agricultural investments that land governance became an issue of common concern, of particular importance for food security and human development. Finally, determination of the beneficiaries is far more complex and context-specific when it comes to benefit-sharing from land use. In particular, difficulties arise with regard to the relationship between different types of land rights and benefit-sharing. A crucial question concerning implementation of benefit-sharing from land use is its relationship with actual access to the resource; the benefit to be shared is often the land itself or the right to use it.

Examination of benefit-sharing is thus inextricably linked to redistribution efforts for land or agrarian reform in view of chronic inequality in land distribution in many countries, complex interactions between formal tenure systems and customary arrangements around the globe and the fundamental question of who has decision-making authority, and thus control over land allocation and use. Control of rights to land has historically been an instrument of oppression and colonization, giving birth to social movements demanding land redistribution as a means towards social justice, and the right to control the type of development undertaken. These movements have recently been a driving force behind international law development, reflected most prominently in the adoption of the UN Declaration on the Rights of Peasants.

As I concluded in the context of agricultural research and development though, promotion of pro-poor and environmental considerations by human rights and environmental instruments is countered by a growing web of transnational trade and investment agreements focused on a neoliberal model of growth. The expanding sphere of application of international investment law, in combination with its enforcement potential and the asymmetry in capacities and power of the parties involved, has resulted in protection of the international capital, often to the detriment of national development priorities in developing countries, restricting states' ability to regulate for the public interest and increasing the risk of dispossession for vulnerable rural populations. The troubled relationship between investment and human rights has attracted the attention of human rights bodies, including the High Commissioner for Human Rights, who highlighted the need to balance competing objectives related to seeking higher investment levels while pursuing 


\section{Benefit-sharing in land governance}

national development objectives. The UN Special Rapporteur on the Rights of Indigenous Peoples Victoria Tauli-Corpuz further noted that the conditions required for the host country to benefit from such investment, and the extent to which international investment agreements enable such conditions, are still open to debate, drawing attention to three legal considerations: the lack of references to human rights obligations in investment agreements; the fear of dispute settlement arbitration, which may restrict the host state's regulatory activity for the public interest; and the lack of public participation in drafting, particularly with regard to the groups that are affected the most, as is the case of indigenous peoples and rural communities in land deals.

In this context, I selected farmers' rights and governance of public lands as focus areas, because they offer the most solid legal basis for benefit-sharing, in the ITPGRFA and VGGT respectively.

Farmers' rights provide a preferential field for the study of benefit-sharing, as they are situated at the interface between the regulation of agricultural research and development, and land and human rights. Discussing their origin and rationale, legal basis in the ITPGRFA and the recently adopted UN Declaration on the Rights of Peasants and implementation challenges in a complex policy context which fails to support user-based innovation and poses a host of obstacles to smallholders, I propose a broad construction of farmers' right to benefit-sharing. This would encompass not only the outcome of benefitsharing as a process, but also a series of supporting elements and enabling conditions. Such elements and conditions would include secure land tenure and access to seeds, as well assistance in the organization of cooperatives and local seed banks, legal recognition of customary agricultural practices, training and access to markets.

This understanding stems first from the ITPGRFA multilateral approach to benefit-sharing, aiming both to reward and to enable farmers' contribution to the conservation and sustainable use of agricultural biodiversity and thus to sustainable agriculture and global food security, as global public goods. Through this twin 'reward and enable' approach, benefit-sharing is linked to farmers' and peasants' rights in their broad sense, and suggests that farmers should not only be rewarded in monetary terms for their contribution, but should also be enabled to continue their practices. In this sense, benefit-sharing appears to operate in two arguably distinct but interlinked forms. The first is the sharing of the benefits arising from the past and present contribution of farmers to the utilization of genetic resources for research and development purposes, and the possible commercialization of the resulting varieties or products. In this form of benefitsharing, farmers are the beneficiaries, entitled to part of the monetary and nonmonetary benefits arising from research and development efforts. The second form relates to the benefits arising from the continued contributions of smallholder farmers, indigenous peoples and local communities as users and stewards of agricultural biodiversity on-farm. These benefits flow to humanity at large as global public goods, and may be considered as part of a set of rights, which would enable farmers' continued contribution to the stewardship of the 
resources in the future. This broad understanding of farmers' right to benefitsharing as integrating enabling and supporting measures seems to be supported by national-level implementation efforts documented by the ITPGRFA Secretariat and academic literature, which range from monetary support through the Treaty's Benefit-sharing Fund and domestic programmes, to training, support to community structures and participatory plant breeding efforts. It also resonates with the conclusions of the field work under BeneLex explored by Louisa Parks (2019), who highlighted that the involved communities more often raised concerns linked to the conditions that need to be in place for discussions on benefit-sharing to begin, with recognition being identified as a central theme, along with community organization and procedural guarantees, among other elements.

Finally, such broad interpretation is further supported by the UN Declaration on the Rights of Peasants, which puts forward a comprehensive approach regarding the rights of rural populations, linking their vulnerabilities, their special relationship to land, water, seeds and natural resources and their contribution to global food security, through rights already protected in international law and new - individual and collective - rights. Importantly, the Declaration includes a series of provisions elaborating on the right to land and to the sustainable use of natural resources, including fair and equitable benefit-sharing in any case of exploitation affecting such natural resources. The outcome of a rare process of direct involvement of social movements in international lawmaking, the Declaration further integrates a series of new concepts, which could potentially impact the development paradigm by drawing attention to peasant autonomy and the broader agrarian struggles for social justice. References to food sovereignty, agrarian reforms to facilitate broad and equitable access to land and other natural resources and the social function of land represent important victories for La Via Campesina in the current neoliberal context shaped by the industrialization of agriculture, trade liberalization, large-scale agricultural investments, speculation in food commodities, the dismantling of public support and criminalization of activists.

When it comes to governance of public lands, application of benefit-sharing considerations may be used to promote fair and equitable use of public lands as follows: through systems of concessions for the use of uncontested public land by individuals or farmer cooperatives for food security and rural livelihoods objectives; and through procedural and substantive safeguards against arbitrary or unfair interference with local land rights, including in the case of large-scale agricultural investments. This conceptualization is supported by elements enshrined in the VGGT and other soft-law instruments, and illustrated by human rights jurisprudence.

The VGGT establish clearly (albeit in a broadly worded manner) a policy objective related to benefit-sharing from public lands, calling on states to strive to develop policies that promote equitable distribution of benefits from stateowned land, fisheries and forests. In addition, redistributive land or agrarian reforms in accordance with the provisions of the VGGT and the UN Peasants 


\section{6}

Benefit-sharing in land governance

Declaration can be considered a tool for benefit-sharing, aiming to share not only the benefits arising from the resource but also the resource itself.

Benefit-sharing considerations have been forwarded in the form of safeguards in the case of large-scale agricultural investments, although questions remain regarding the relationship between benefit-sharing and land-use rights, particularly customary ones. That is, empirical research shows that in many cases doubtful or strictly monetary benefit-sharing arrangements tend to replace legitimate land-use rights. Such failure to consider the broader benefits that people get from natural resources has detrimental effects for livelihoods and social cohesion, reproducing injustices and imposing dominant ideological, economic and development models. Literature on the actual implementation of benefit-sharing arrangements via either policy interventions or contractual provisions remains limited, illustrating the need to bridge the gap in legal commentary and provide a comprehensive picture of the socio-legal framework and its implementation on the ground, from the international to the national and the local level.

That said, two issues are of particular relevance for the study and conceptualization of fair and equitable benefit-sharing in the case of large-scale agricultural investments: the potential mismatch between macro-level benefits at the government level and negative impacts on local-level livelihoods, resulting in unfair distribution of risks and benefits; and procedural shortcomings in the design and implementation of such agreements, due to a series of structural considerations related to national frameworks characterized by poor governance. Traditional legal tools such as impact assessments including their participation requirements can be used to build the enabling conditions and allow for meaningful sharing of benefits arising from an investment or development.

In this context, benefit-sharing considerations can come into play as follows: as opportunities for meaningful participation and recognition of legitimate right holders in the decision-making process; in terms of safeguards for local land rights against arbitrary or unfair interference, to be included in the cost-benefit assessment process; and finally in the form of contractual arrangements for revenue-sharing and non-monetary benefits such as infrastructure development. Benefit-sharing thus relates to both its enabling conditions related to participation in the decision-making process, and the substantive outcomes. The concept thus again needs to be understood and constructed broadly in the context of the VGGT, which provide guidance both on the protection of legitimate tenure rights, and on mechanisms for transparency, participation and accountability in decision-making regarding land allocation.

Even in the case of legitimate agreements, however - that is, agreements which have respected the national laws in question and are in accordance with international human rights standards - the question of who retains the decisionmaking authority, and thus control over land allocation and use, remains. Such authority would generally rest with the central government, and is usually accompanied by a broad definition of public purpose requirements. Imposition of 
a decision in the context of diverging views with regard to livelihood choices and aspirations and the preferred development model may result in grassroots contestation of the project, and further socio-economic and cultural marginalization of rural populations. Time will show whether the VGGT and the UN Peasants Declaration will build on their emancipatory potential and empower rural populations, including by influencing power structures and providing them with the necessary political leverage.

\section{Notes}

1 Voluntary guidelines endorsed by the UN Committee on World Food Security on 11 May 2012.

2 Voluntary guidelines adopted by the FAO Council in November 2004.

3 Resolution adopted by the UN General Assembly in December 2018, UN Doc A/RES/ $73 / 165$.

4 The parable goes as follows. Three children fight over a flute. Anne says she deserves the flute because she is the only one who knows how to play it. Bob says he is so poor that he is the only child who has no toys at all, so at least he should have the flute. Carla says the flute is hers because she made it.

5 Agenda 21, paragraph 10.5 .

6 Mayagna (Sumo) Awas Tingni Community v. Nicaragua (31 August 2001), Judgment of the Inter-American Court of Human Rights, Series C no. 79.

7 Organization of American States, American Convention on Human Rights, 22 November 1969.

8 Organization of African Unity, African Charter on Human and Peoples' Rights (Banjul Charter), 27 June 1981, CAB/LEG/67/3 rev. 5, 21 I.L.M. 58 (1982).

9 Centre for Minority Rights Development (Kenya) and Minority Rights Group (on behalf of Endorois Welfare Council) v. Kenya (2010), Decision of the African Commission on Human and Peoples' Rights, Case 276/2003.

10 UN Declaration on the Rights of Indigenous Peoples, adopted by the UN General Assembly (13 September 2007), UN Doc A/61/295.

11 UN Convention to Combat Desertification in Countries Experiencing Serious Drought and/or Desertification, Particularly in Africa (adopted 14 December 1994, entered into force 26 December 1996), 1954 UNTS 3.

12 ICCD/COP(14)/L.17 (2019), 'New and Emerging Issues: Land Tenure'.

13 CBD Decision XI/3 (2012), 'Monitoring Progress in Implementation of the Strategic Plan for Biodiversity 2011-2020 and the Aichi Biodiversity Targets', Annex: Indicative List of Indicators for the Strategic Plan for Biodiversity 2011-2020, Target 18.

14 Akwé: Kon Voluntary Guidelines for the Conduct of Cultural, Environmental and Social Impact Assessments Regarding Developments Proposed to Take Place on, or which are Likely to Impact on, Sacred Sites and on Lands and Waters Traditionally Occupied or Used by Indigenous and Local Communities (2004), adopted by the seventh meeting of the CBD Conference of the Parties.

15 Case of the Saramaka People v. Suriname (2007), Inter-American Court of Human Rights, Judgment on preliminary objections, merits, reparations, and costs, IACHR Series C no 172, IHRL 3046.

16 Case of the Saramaka People v. Suriname (2008), Inter-American Court of Human Rights, Interpretation of the Judgment on Preliminary Objections, Merits, Reparations and Costs, IACHR Series C No 185, IHRL 3058.

17 Ibid., para. 41 and fn. 23.

18 Decision 3/COP.8 (2007): 'The Ten-Year Strategic Plan and Framework to Enhance the Implementation of the Convention (2008-2018)'. 


\section{Benefit-sharing in land governance}

19 Decision 7/COP.13 (2017): 'The Future Strategic Framework of the Convention: The UNCCD 2018-2030 Strategic Framework'.

20 I am grateful to Antonia Zydek for her valuable assistance with a literature review on the right to food.

21 Monsanto Canada Inc. v. Schmeiser (2004) 1 SCR 902, SCC 34; Bowman v. Monsanto Co. (2013) 133 S Ct 1761.

22 Commission Directive 2008/62/EC of 20 June 2008 Providing for Certain Derogations for Acceptance of Agricultural Landraces and Varieties which are Naturally Adapted to the Local and Regional Conditions and Threatened by Genetic Erosion and for Marketing of Seed and Seed Potatoes of those Landraces and Varieties.

23 For the purposes of this analysis, these include Council Directive 2002/53/EC of 13 June 2002 on the Common Catalogue of Varieties of Agricultural Plant Species, and Council Directive 2002/55/EC of 13 June 2002 on the Marketing of Vegetable Seed.

24 Commission Directive 2009/145/EC of 26 November 2009 Providing for Certain Derogations, for Acceptance of Vegetable Landraces and Varieties which have been Traditionally Grown in Particular Localities and Regions and are Threatened by Genetic Erosion and of Vegetable Varieties with No Intrinsic Value for Commercial Crop Production but Developed for Growing under Particular Conditions and for Marketing of Seed of those Landraces and varieties.

25 Case C-59/11, Association Kokopelli v. Graines Baumaux SAS.

26 Law for the Reclaiming of Biodiversity, Nature and Landscapes (July 2016), available (in French) at: www.legifrance.gouv.fr/affichTexte.do?cidTexte=JORFTEXT00003301 6237\&categorieLien=id (last accessed 20.12.2019); and Law for the Balance of Commercial Relationships in the Agricultural and Food Sector and for a Healthy and Sustainable Nutrition (November 2018), available at: www.legifrance.gouv.fr/affich Texte.do;jsessionid=1131AC8F8F2FEB5BB59BAC3F1497F4B2.tplgfr30s_1?cidTexte= JORFTEXT000037547946\&categorieLien=id (last accessed 20.12.2019).

27 I am grateful to Vasso Kanellopoulou of the Peliti community who drew my attention to this development.

28 Again, I am grateful to Vasso Kanellopoulou for pointing to the Danish legislation.

29 La Via Campesina (2007) 'Declaration of the Forum for Food Sovereignty', Nyéléni Village, Sélingué, Mali, available at: https://nyeleni.org/spip.php?article290 (last accessed 15.11.2019).

30 Declaration on Social Progress and Development, proclaimed by UN General Assembly Resolution 2542 (XXIV) of 11 December 1969.

31 The case study draws from my post on the BeneLex blog, available at: https:// benelexblog.wordpress.com/2016/10/10/access-to-markets-for-smallholders-and-fairand-equitable-benefit-sharing-mapping-the-linkages/ (last accessed 10.11.2019).

32 'Policy Recommendations on Investing in Smallholder Agriculture for Food Security and Nutrition' (2013), available at: www.fao.org/3/a-av034e.pdf (last accessed 10.11.2019).

33 'Policy Recommendations on Connecting Smallholders to Markets' (2016), available at: www.fao.org/3/a-bq853e.pdf (last accessed 10.11.2019).

34 Greek Law 4061/2012 as amended, available (in Greek) at: www.kodiko.gr/nomologia/ document_navigation/66029/nomos-4061-2012 (last accessed 10.12.2019).

35 Human Rights Council Resolution 17/4 (2011).

36 Chairmanship Revised Draft (16.7.2019): 'Legally Binding Instrument to Regulate, in International Human Rights Law, the Activities of Transnational Corporations and other Business Enterprises', available at: www.ohchr.org/Documents/HRBodies/HRCouncil/ WGTransCorp/OEIGWG_RevisedDraft_LBI.pdf (last accessed 10.1.2020).

37 Communication from the Commission to the Council and the European Parliament, Guidelines to Support Land Policy Design and Reform Processes in Developing Countries, $\operatorname{COM}(2004) 686$ final. 
38 The New European Consensus on Development, 'Our World, Our Dignity, Our Future', Joint Statement by the Council and the Representatives of the Governments of the Member States Meeting within the Council, the European Parliament and the European Commission, available at: https://ec.europa.eu/international-partnerships/ system/files/european-consensus-on-development-final-20170626_en.pdf (last accessed 14.1.2020).

39 UN Committee on the Elimination of Racial Discrimination (2003) 'Consideration of Reports Submitted by States Parties under Article 9 of the Convention: Concluding Observations on Ecuador', UN Doc CERD/C/62/CO/2.

40 Order of the Inter-American Court of Human Rights (2018), 'Case of the Saramaka People v. Suriname: Monitoring Compliance with Judgment'.

41 The Ikarian case study is based on the work of Louisa Parks (2019) and Maria Bareli (2018); the collaborative effort that resulted in Bareli et al. (2020); and interviews with local actors, including pastoralists, local authorities and civil society members, conducted by Louisa Parks and myself during the two visits to Ikaria as part of BeneLex field work.

42 Council Regulation (EC) No 1099/2009 of 24 September 2009 on the Protection of Animals at the Time of Killing; Regulation (EC) No 852/2004 of the European Parliament and of the Council of 29 April 2004 on Hygiene of Foodstuffs; and Regulation (EC) No 853/2004 of the European Parliament and of the Council of 29 April 2004 Laying Down Specific Hygiene Rules for Food of Animal Origin.

43 Council Regulation (EC) No 1/2005 of 22 December 2004 on the Protection of Animals during Transport and Related Operations and Amending Directives 64/432/ EEC and 93/119/EC and Regulation (EC) No 1255/97.

44 According to preambular paragraph 15 of the Regulation 1099/2009, the legislative or administrative provisions and customs of the member states relating, in particular, to religious rites, cultural traditions and regional heritage are to be respected. Cultural events are therefore excluded from the scope of the regulation, where compliance with animal welfare requirements would adversely affect the very nature of the event concerned.

\section{References}

Adams, M. (1995) 'Land Reform: New Seeds on Old Ground?', ODI Briefing Paper, London: Overseas Development Institute.

Agarwal, B. (1994) A Field of One's Own: Gender and Land Rights in South Asia. Cambridge: Cambridge University Press.

Agarwal, B. (2003) 'Gender and Land Rights Revisited: Exploring New Prospects via the State, Family and Market', The Journal of Agrarian Change, 3(1-2): 184-224.

Almekinders, C. J. M., Louwaars, N. and de Bruijn, G. (1994) 'Local Seed Systems and their Importance for an Improved Seed Supply in Developing Countries', Euphytica, 78: 207-216.

Ambalam, K. (2014) 'Challenges of Compliance with Multilateral Environmental Agreements: the Case of the United Nations Convention to Combat Desertification in Africa', Journal of Sustainable Development Studies, 5(2): 145-168.

Anaya, J. (2005) 'Indigenous Peoples' Participatory Rights in Relation to Decision about Natural Resource Extraction: The More Fundamental Issue of What Rights Indigenous Peoples Have in Lands and Resources', Arizona Journal of International and Comparative Law, 22(7): 7-17.

Andersen, R. (2005) The History of Farmers' Rights. A Guide to Central Documents and Literature, FNI Report 8/2005. Lysaker: Fridtjof Nansen Institute. 
Andersen, R. (2006) Realising Farmers' Rights Under the International Treaty on Plant Genetic Resources for Food and Agriculture: Summary of Findings from the Farmers' Rights Project, Phase 1, FNI Report 11/2006. Lysaker: Fridtjof Nansen Institute.

Andersen, R. (2013) 'Norway's Path to Ensuring Farmers' Rights in the European Context', in R. Andersen and T. Winge (eds), Realising Farmers' Rights to Crop Genetic Resources: Success Stories and Best Practices. Abingdon: Routledge.

Andersen, R. and Winge, T. (eds) (2013) Realising Farmers' Rights to Crop Genetic Resources: Success Stories and Best Practices. Abingdon: Routledge.

Ankersen, T. and Ruppert, T. (2006) 'Tierra y Libertad: The Social Function Doctrine and Land Reform in Latin America', Tulane Environmental Law Journal, 19: 69-120.

Argumedo, A., Swiderska, K., Pimbert, M., Song, Y. and Pant, R. (2011) Implementing Farmers' Rights under the FAO International Treaty on PGRFA: The Need for a Broad Approach Based on Biocultural Heritage, IIED Report. London: International Institute for Environment and Development.

Aroni-Tsichli, K. (2000) 'O Polemos ths Stafidas [The War of Raisin]', Mnimon 22: 247-258.

Azevedo, C. (2016) 'Gaining Land and Gaining Ground? The Popular Agrarian Reform by the Landless Rural Workers' Movement (MST) in Brazil', Paper no. 52: International Colloquium on Global Governance/Politics, Climate Justice and Agrarian/ Social Justice: Linkages and Challenges, available at: www.iss.nl/sites/corporate/ files/52-ICAS_CP_Azevedo.pdf (last accessed 13.12.2019).

Bareli, M. (2018) 'Ta ikariotika paniyiria tou Mesopolemou: opseis tou dorou kai praktikes ton koinon' [The Mid-War Ikarian Paniyiries: Facets of the Gift and Practices of the Commons], in Y. Zaimakis (ed.), Ereynitikes diadromes stis koinonikes epistimes: theoritikes-methodologikes sumvoles kai meletes periptosis [Research Routes in Social Sciences: Theoretical-Methodological Contributions and Case Studies]. Rethymno: University of Crete.

Bareli, M., Geelhoed, M., Parks, L., Morgera, E. and Tsioumani, E. (2020) 'The Unintended Consequences of the EU's Common Agricultural Policy for Local Communities', in P. J. Cardwell and M.-P. Granger (eds), Research Handbook on the Politics of EU Law. Cheltenham: Edward Elgar.

Bernasconi-Osterwalder, N., Cosbey, A., Johnson, L. and Vis-Dunbar, D. (2012) Investment Treaties and Why They Matter to Sustainable Development: Questions and Answers. Winnipeg, MB: IISD.

Berger, T. and Tsioumani, E. (2019) BeneLex Learning Module on Benefit-Sharing and Farmers' Rights. Glasgow: Strathclyde Centre for Environmental Law and Governance, available at: www.strath.ac.uk/research/strathclydecentreenvironmentallawgov ernance/benelex/researchoutputs/learningmodules/moduleonfarmersrights/ (last accessed 12.5.2020).

Binswanger-Mkhize, H. P., Bourguignon, C. and van den Brink, R. (eds) (2009) Agricultural Land Redistribution: Towards Greater Consensus. Washington, DC: International Bank for Reconstruction and Development/World Bank Group.

Bioversity International (2018) Biodiversity Mainstreaming for Healthy and Sustainable Food Systems: A Toolkit to Support Incorporating Biodiversity into Policies and Programmes. Rome: Bioversity.

Bocci, R. (2014) 'Seeds between Freedom and Rights', Science del Territorio, 2: $115-122$. 
Brockhaus, M., Wong, G., Luttrell, C., Loft, L., Pham, T. T., Duchelle, A. E., AssembeMvondo, S. and Di Gregorio, M. (2014) Operationalizing Safeguards in National REDD+ Benefit-Sharing Systems: Lessons on Effectiveness, Efficiency and Equity. Bogor: CIFOR.

Brockington, D. (2004) 'Community Conservation, Inequality and Injustice: Myths of Power in Protected Area Management', Conservation and Society, 2(2): 411-432.

Brunori, M. (2015) 'Principles on Responsible Investment in Agriculture and Food Systems: A (Very) Critical Analysis', BeneLex blogpost, available at: https:// benelexblog.wordpress.com/2015/05/21/principles-on-responsible-investment-inagriculture-and-food-systems-a-very-critical-analysis/ (last accessed 14.1.2020).

Carter, M. R. (2003) 'Designing Land and Property Rights Reform for Poverty Alleviation and Food Security', Land Reform, Land Settlement and Cooperatives, 2: 44-57.

CFS (2016) CFS 42 High Level Forum on Connecting Smallholders to Markets, June 2015 - Background Document. Rome: Committee on World Food Security.

Chouquer, G. (2011) 'Aspects and Characteristics of State-Owned Land in West Africa', Briefing Note: Land Tenure and Development Technical Committee. Available at: www.agter.org/bdf/en/corpus_chemin/fiche-chemin-147.html (last accessed 10.12.2019).

Cipollina, M., Cuffaro, N. and D'Agostino, G. (2018) 'Land Inequality and Economic Growth: A Meta-Analysis', Sustainability, 10(12): 4655-4675.

Claeys, P. and Edelman, M. (2019) 'The United Nations Declaration on the Rights of Peasants and other People Working in Rural Areas', The Journal of Peasant Studies, early electronic publication, DOI: 10.1080/03066150.2019.1672665.

Colchester, M. (ed.) (2001) A Survey of Indigenous Land Tenure, Report for the Land Tenure Services of the Food and Agriculture Organization. Moreton-in-Marsh: Forest Peoples Programme.

Cotula, L. (2015) Land Rights and Investment Treaties: Exploring the Interface. London: IIED.

Cotula, L. (2016) “"Land Grabbing” and International Investment Law: Toward a Global Reconfiguration of Property', in A. K. Bjorklund (ed.), Yearbook on International Investment Law and Policy. Oxford: Oxford University Press.

Cotula, L. (2017a) 'Land, Property and Sovereignty in International Law', Cardozo Journal of International and Comparative Law, 25(2): 219-286.

Cotula, L. (2017b) 'International Soft-Law Instruments and Global Resource Governance: Reflections on the Voluntary Guidelines on the Responsible Governance of Tenure', Law, Environment and Development Journal, 13(2): 115-135.

Cotula, L. and Berger, T. (2015) Land Deals and Investment Treaties: Visualising the Interface, London: IIED.

Cotula, L., Vermeulen, S., Leonard, R. and Keeley, J. (2009) Land Grab or Development Opportunity? Agricultural Investment and International Land Deals in Africa. Rome; London: FAO, IFAD, IIED.

Correa, C. (2000) Options for the Implementation of Farmers' Rights at the National Level. Geneva: South Centre.

Dahlberg, A., Rohde, R. and Sandell, K. (2010) 'National Parks and Environmental Justice: Comparing Access Rights and Ideological Legacies in Three Countries', Conservation and Society, 8(3): 209-224.

Deininger, K. and Byerlee, D. with Lindsay, J., Norton, A., Selod, H. and Stickle, M. (2011) Rising Global Interest in Farmland: Can It Yield Sustainable and Equitable Benefits? Washington, DC: World Bank Group. 
De Lucia, V. (2019) The 'Ecosystem Approach' in International Environmental Law: Genealogy and Biopolitics. Abingdon: Routledge.

De Schutter, O., UN Special Rapporteur on the Right to Food (2009) Seed Policies and the Right to Food: Enhancing Agrobiodiversity and Encouraging Innovation, UN Doc A/64/170.

De Schutter, O., UN Special Rapporteur on the Right to Food (2010) Large-Scale Land Acquisitions and Leases: A Set of Minimum Principles and Measures to Address the Human Rights Challenge, UN Doc A/HRC/13/33/Add.2.

De Schutter, O., UN Special Rapporteur on the Right to Food (2011) 'How Not to Think of Land-Grabbing: Three Critiques of Large-Scale Investments in Farmland', The Journal of Peasant Studies, 38(2): 249-279.

Edelman, M. (2014) 'Linking the Rights of Peasants to the Right to Food in the United Nations', Law, Culture and the Humanities, 10(2): 196-211.

Elfstrand, S., Malmer, P. and Skagerfalt, B. (2011) Strengthening Agricultural Biodiversity for Smallholder Livelihoods: What Knowledge is Needed to Overcome Constraints and Release Potentials? Stockholm: Stockholm Resilience Centre.

European Coordination Via Campesina (2018) Food Sovereignty Now! A Guide to Food Sovereignty. Brussels: La Via Campesina.

European Economic and Social Committee (2015) Land Grabbing: A Warning for Europe and a Threat to Family Farming, Own-Initiative Opinion NAT/632. Brussels: EESC.

FAO (1993) Harvesting Nature's Diversity. Rome: FAO.

FAO (2002a) Law and Sustainable Development since Rio: Legal Trends in Agriculture and Natural Resource Management, FAO Legislative Study 73. Rome: FAO.

FAO (2002b) Gender and Access to Land, Land Tenure Studies no. 4. Rome: FAO.

FAO (2002c) Land Tenure and Rural Development, Land Tenure Studies no. 3. Rome: FAO.

FAO (2011) Report on the Symposium on Legal Aspects of Large Scale Investments in Land: Implications for Food Security and Rural Development. Rome: FAO.

FAO (2015) Safeguarding Land Tenure Rights in the Context of Agricultural Investment, Governance of Tenure Technical Guide no. 4. Rome: FAO.

FAO (2018) Farmer Seed Systems and Sustaining Peace. Rome: FAO.

Fischer, G., Tothne Hizsnyik, E. T., Prieler, S. and Wiberg, D. (2011) Scarcity and Abundance of Land Resources: Competing Uses and the Shrinking Land Resource Base, The State of the World's Land and Water Resources for Food and Agriculture (SOLAW) Thematic Report 02. Rome: FAO.

Franco, J. C., Monsalve, S. and Borras, S. M. (2015) 'Democratic Land Control and Human Rights', Current Opinion in Environmental Sustainability, 15: 66-71.

Fraser, E. (2003) 'Social Vulnerability and Ecological Fragility: Building Bridges between Social and Natural Sciences using the Irish Potato Famine as a Case Study', Conservation Ecology, 7(2): 9.

Frison, C. (2018) Redesigning the Global Seed Commons: Law and Policy for Agrobiodiversity and Food Security. Abingdon: Routledge.

Gallico, L. and Groppo, P. (2016) 'VGGT as a Tool for Improving Access to Land and the Responsible Management of Natural Resources: Based on the Experience of Lazio Region and Rome Municipality', Paper no. 24: International Colloquium on Global Governance/Politics, Climate Justice and Agrarian/Social Justice: Linkages and Challenges, available at: www.iss.nl/sites/corporate/files/24-ICAS_CP_Gallico_and_Groppo. pdf (last accessed 13.12.2019). 
Gilbert, J. (2013) 'Land Rights as Human Rights', SUR 18, available at: https://sur. conectas.org/en/land-rights-human-rights/ (last accessed 2.9.2019).

Glowka, L. and Normand, V. (2013) 'The Nagoya Protocol on Access and BenefitSharing: Innovations in International Environmental Law', in E. Morgera, M. Buck and E. Tsioumani (eds), The 2010 Nagoya Protocol on Access and Benefit-sharing in Perspective. Leiden: Brill.

GRAIN (2019a) 'Asia under threat of UPOV 91', available at: www.grain.org/en/ article/6372-asia-under-threat-of-upov-91 (last accessed 6.12.2019).

GRAIN (2019b) GRAIN in 2018: Highlights of our Activities, available at: www.grain. org/en/article/6188-grain-s-2018-activity-report (last accessed 6.12.2019).

Grindle, M. S. (2007) Going Local: Decentralization, Democratization, and the Promise of Good Governance. Woodstock: Princeton University Press.

Groppo, P. (ed.) (2003) Land Reform, Land Settlement and Cooperatives: Special Edition, 2003(3). Rome: FAO.

Guadagni, M. (2002) 'Trends in Customary Land Property', in M. E. Sánchez Jordan and A. Gambaro (eds), Land Law in Comparative Perspective. Alphen aan den Rijn: Kluwer.

Guneratne, C. (2012) Genetic Resources, Equity and International Law. Cheltenham: Edward Elgar.

Hall, R. and Scoones, I. with Henley, G. (2016) Strengthening Land Governance: Lessons from Implementing the Voluntary Guidelines, LEGEND State of the Debate Report. DFID: London.

Hardin, G. (1968) 'The Tragedy of the Commons', Science, 162(3859): 1243-1248.

Harvey, D. (2003) The New Imperialism. Oxford: Oxford University Press.

Headey, D. and Fan, S. (2010) Reflections on the Global Food Crisis: How Did it Happen? How Has it Hurt? And How Can We Prevent the Next One? Washington, DC: International Food Policy Research Institute.

Heller, M. (1998) 'The Tragedy of the Anticommons: Property in the Transition from Marx to Markets', Harvard Law Review, 111(3): 621-688.

Heller, M. and Eisenberg, R. (1998) 'Can Patents Deter Innovation? The Anticommons in Biomedical Research’, Science, 280(5364): 698-701.

HLPE (2011) Land Tenure and International Investments in Agriculture. A Report by the High Level Panel of Experts on Food Security and Nutrition of the Committee on World Food Security. Rome: Committee on World Food Security.

HLPE (2013) Investing in Smallholder Agriculture for Food Security. A Report by the High Level Panel of Experts on Food Security and Nutrition of the Committee on World Food Security. Rome: Committee on World Food Security.

IFAD (2013) Smallholders, Food Security, and the Environment. Rome: International Fund for Agricultural Development.

ITPGRFA Secretariat (2017) Farmers' Rights under the International Treaty: Educational Module. Rome: FAO.

Jackson, C. (2003) 'Gender Analysis of Land: Beyond Land Rights for Women?', Journal of Agrarian Change, 3(4): 453-480.

Jacques, P. and Racine Jacques, J. (2012) 'Monocropping Cultures into Ruin: The Loss of Food Varieties and Cultural Diversity', Sustainability, 4(11): 2970-2997.

Kastler, G. and Moÿ, A. C. (2013) 'The European Union Directive on Conservation Varieties and its Incompatibility with On-Farm Management of Plant Genetic Resources', in W. S. De Boef, N. Peroni, A. Subedi, M. H. Thijssen and E. O'Keeffe (eds), Community Biodiversity Management: Promoting Resilience and the Conservation of Plant Genetic Resources. Abingdon: Routledge. 
Kinealy, C. (1997) 'Food Exports from Ireland 1846-47', History Ireland, 5(1): 32-36.

Knight, R. (2010) Statutory Recognition of Customary Land Rights in Africa: An Investigation into Best Practices for Law Making and Implementation, FAO Legislative Study 105. Rome: FAO.

Koorndijk, J. L. (2019) 'Judgements of the Inter-American Court of Human Rights Concerning Indigenous and Tribal Land Rights in Suriname: New Approaches to Stimulating Full Compliance', The International Journal of Human Rights, 23(10): 1615-1647.

Le Courtois, E., with Gálvez-Nogales, E., Santacoloma, P. and Tartanac, F. (2011) 'Enhancing Farmers' Access to Markets for Certified Products: A Comparative Analysis Using a Business Model Approach', FAO Agricultural Management, Marketing and Finance Working Document 28. Rome: FAO.

Lee, J., Gereffi, G. and Beauvais, J. (2012) 'Global Value Chains and Agrifood Standards: Challenges and Possibilities for Smallholders in Developing Countries', Proceedings of the National Academy of Science of the USA, 109(31): 12326-12331.

Louwaars, N. (2007) Seeds of Confusion: The Impact of Policies on Seed Systems, PhD dissertation, Wageningen: Wageningen University.

Luttrell, C., Loft, L., Gebara, M., Kweka, D., Brockhaus, M., Angelsen, A. and Sunderlin, W. (2013) 'Who Should Benefit from REDD+? Rationales and Realities', Ecology and Society, 18(4): 52-70.

Macklem, P. (2015) 'Human Rights in International Law: Three Generations or One?', London Review of International Law, 3(1): 61-92.

Martin, A., Akol, A. and Phillips, J. (2014) 'Just Conservation? On the Fairness of Sharing Benefits', in T. Sikor (ed.), The Justices and Injustices of Ecosystem Services, London: Earthscan.

McDermott, M., Mahanty, S. and Schreckenberg, K. (2013) 'Examining Equity: A Multidimensional Framework for Assessing Equity in Payments for Ecosystem Services', Environmental Science and Policy, 33: 416-427.

McGuire, S. (2008) 'Securing Access to Seed: Social Relations and Sorghum Seed Exchange in Eastern Ethiopia', Human Ecology, 36(2): 217-229.

McGuire, S. and Sperling, L. (2016) 'Seed Systems Smallholder Farmers Use', Food Security, 8: 179-195.

Merlet, M. (2007) Land Policies and Agrarian Reforms, Proposal paper. Nogent-surMarne: AGTER.

Morgera, E. (2017) 'The Ecosystem Approach and the Precautionary Principle', in J. Razzaque and E. Morgera (eds), Encyclopedia of Environmental Law: Biodiversity and Nature Protection Law. Cheltenham: Edward Elgar.

Morgera, E. (2019) 'Under the Radar: The Role of Fair and Equitable Benefit-Sharing in Protecting and Realising Human Rights Connected to Natural Resources', International Journal of Human Rights, 23(7): 1098-1139.

Morgera, E. and Tsioumani, E. (2010) 'The Evolution of Benefit-Sharing: Linking Biodiversity and Community Livelihoods', Review of European Community and International Environmental Law, 19(2): 150-173.

Morgera, E., Tsioumani, E., Aguilar, S. and Wilkins, H. (2012) 'Implementation Challenges and Compliance in MEA Negotiations', in P. Chasek and L. Wagner (eds), The Roads from Rio: Lessons Learned from Twenty Years of Multilateral Environmental Negotiations. Abingdon: Routledge.

Morgera, E., Tsioumani, E. and Buck, M. (2014) Unraveling the Nagoya Protocol: A Commentary on the Nagoya Protocol on Access and Benefit-Sharing to the Convention on Biological Diversity. Leiden: Brill. 
Orellana, M. (2008) 'Saramaka People v. Suriname', The American Journal of International Law, 102(4): 841-847.

Ostrom, E. and Hess, C. (2008) 'Private and Common Property Rights', Indiana University School of Public \& Environmental Affairs Research Paper No. 2008-11-01, available at: https://ssrn.com/abstract=1936062 (last accessed 29.12.2019).

Oxfam, International Land Coalition and Rights and Resources Initiative (2016) Common Ground: Securing Land Rights and Safeguarding the Earth. Oxford: Oxfam.

Parks, L. (2019) Benefit-Sharing in Environmental Governance: Local Experiences of a Global Concept. Abingdon: Routledge.

Peschard, K. (2014) 'Farmers' Rights and Food Sovereignty: Critical Insights from India', The Journal of Peasant Studies, 41(6): 1085-1108.

Peschard, K. (2017) 'Seed Wars and Farmers' Rights: Comparative Perspectives from Brazil and India', The Journal of Peasant Studies, 44(1): 144-168.

Peskett, L. (2011) Benefit Sharing in REDD+: Exploring the Implications for Poor and Vulnerable People. Washington, DC: World Bank and REDD-net.

Pham, T. T., Brockhaus, M., Wong, G., Dung, L. N., Tjajadi, J. S., Loft, L., Luttrell C. and Assembe Mvondo, S. (2013) Approaches to Benefit Sharing: A Preliminary Comparative Analysis of 13 REDD+ Countries, Working Paper 108. Bogor: CIFOR.

Ragavan, S. and O' Shields, J. M. (2007) 'Has India Addressed Its Farmers' Woes? A Story of Plant Protection Issues', The Georgetown International Environmental Law, 20: 97-127.

Réseau Semences Paysannes (2018) 'Conseil Constitutionnel, Décision n² 2018-771 DC du 25 octobre 2018, Loi pour l'équilibre des relations commerciales dans le secteur agricole et alimentaire et une alimentation saine, durable et accessible à tous', available at: https://ressources.semencespaysannes.org/veille/fiche-veille-2443.html (last accessed 20.12.2019).

Rezvani, L. (2020) 'Plants and their Peasants: A More-than-Human Approach to Plant Breeding and Seed Politics in Brittany, France', International Institute of Social Studies Working Paper no. 653, available at: https://repub.eur.nl/pub/124280 (last accessed 3.2.2020).

Robinson, B. E., Masuda, Y. J., Kelly, A. C., Holland, M. B., Bedford, C. H., Childress, M. D., Fletschner, D. K., Game, E. T., Ginsburg, C. M., Hilhorst, T. J., Lawry, S., Miteva, D. A., Musengezi, J., Naughton-Treves, L., Nolte, C., Sunderlin, W. D. and Veit, P. G. (2018) 'Incorporating Land Tenure Security into Conservation', Conservation Letters, 11(2): 1-11.

Rombouts, B., Meijknecht, A. and Asarfi, J. (2016) The Implementation of IACtHR Judgments Concerning Land Rights in Suriname - Saramaka people v. Suriname and Subsequent Cases: International Law Association Committee on the Implementation of the Rights of Indigenous Peoples, Case Study. London: International Law Association.

Rosset, P. (2000) 'The Multiple Functions and Benefits of Small Farm Agriculture in the Context of Global Trade Negotiations', Development, 43(2): 77-82.

Rosset, P., Patel, R. and Courville, M. (eds) (2006) Promised Land: Competing Visions of Agrarian Reform. Oakland, CA: Food First Books.

Russett, B. (1964) 'Inequality and Instability: The Relation of Land Tenure to Politics', World Politics, 16(3): 442-454.

Sandwell, K., Castañeda Flores, A., Forero, L. F., Franco, J., Monsalve Suárez, S., Nuila, A. and Seufert, P. (2019) A View from the Countryside: Contesting and Constructing Human Rights in an Age of Converging Crises, TNI Issue Brief. Amsterdam: Transnational Institute. 
Santilli, J. (2013) 'Local Varieties, Informal Seed Systems and the Seed Law: Reflections from Brazil', in W. Simon de Boef, A. Subedi, N. Peroni, M. Thijssen and E. O'Keeffe (eds), Community Biodiversity Management: Promoting Resilience and the Conservation of Plant Genetic Resources. Abingdon: Routledge.

Sarmiento Barletti, J. P and Larson, A. M. (2017) 'Rights Abuse Allegations in the Context of REDD+ Readiness and Implementation: A Preliminary Review and Proposal for Moving Forward', CIFOR Info Brief 190. Bogor: CIFOR.

Schlager, E. and Ostrom, E. (1992) 'Property-Rights Regimes and Natural Resources: A Conceptual Analysis', Land Economics, 68(3): 249-262.

Scoones, I., Edelman, M., Borras, S. M., Hall, R., Wolford, W. and White, B. (2018) 'Emancipatory Rural Politics: Confronting Authoritarian Populism', The Journal of Peasant Studies, 45(1): 1-20.

Seed Freedom (2016) 'Denmark Interprets EU Seed Laws in Support of Seed Saving', available online at: https://seedfreedom.info/denmark-interprets-eu-seed-laws-in-supportof-seed-saving/ (last accessed 28.12.2019).

Sen, A. (2009) The Idea of Justice. Cambridge, MA: Belknap Press of Harvard University Press.

Shawki, N. (2014) 'New Rights Advocacy and the Human Rights of Peasants: La Via Campesina and the Evolution of New Human Rights Norms', Journal of Human Rights Practice, 6(2): 306-326.

Sidaner, E., Balaban, D. and Burlandy, L. (2013) 'The Brazilian School Feeding Programme: An Example of an Integrated Programme in Support of Food and Nutrition Security', Public Health Nutrition, 16(6): 989-994.

Smith, P., Gregory, P., van Vuuren, D., Obersteiner, M., Havlik, P., Rounsevell, M., Woods, J., Stehfest, E. and Bellarby, J. (2010) 'Competition for Land', Philosophical Transactions of the Royal Society B: Biological Sciences, 365(1554): 2941-2957.

Spataro, G. and Negri, V. (2013) 'The European Seed Legislation on Conservation Varieties: Focus, Implementation, Present and Future Impact on Landrace on Farm Conservation', Genetic Resources and Crop Evolution, 60(8): 2421-2430.

Sperling, L., Boettiger, S. and Barker, I. (2014) 'Integrating Seed Systems', Planning for Scale Brief \# 3: AgPartnerXChange, available at: https://seedsystem.org/wp-content/ uploads/2014/03/Integrating-Seed-Systems-.pdf (last accessed 15.11.2019).

Stevens, S. (1997) Conservation through Cultural Survival: Indigenous Peoples and Protected Areas. Washington, DC: Island Press.

Stiglitz, J. (2012) The Price of Inequality: How Today's Divided Society Endangers Our Future. New York: Norton.

Stringer, L., Reed, M., Dougill, A., Seely, M. and Rokitzki, M. (2007) 'Implementing the UNCCD: Participatory Challenges’, Natural Resources Forum, 31: 198-211.

Tauli-Corpuz, V., UN Special Rapporteur on the Rights of Indigenous Peoples (2016) 'Annual Report: International Investment Agreements, Including Bilateral Investment Treaties and Investment Chapters of Free Trade Agreements', UN Doc A/HRC/33/42.

Thiele, G. (1999) 'Informal Potato Seed Systems in the Andes: Why are they Important and What Should We Do with Them?', World Development, 27(1): 83-99.

Thrupp, L. A. (2000) 'Linking Agricultural Biodiversity and Food Security: The Valuable Role of Sustainable Agriculture', International Affairs, 76(2): 265-281.

Tsioumani, E. (2014) Exploring Benefit-Sharing from the Lab to the Land (Part I): Agricultural Research and Development in the Context of Conservation and Sustainable Use, BeneLex Working Paper 4, available at: https://papers.ssrn.com/sol3/papers. cfm?abstract_id=2524337 (last accessed 3.11.2019). 
Tsioumani, E. (2017) 'Drylands: Ecosystems, People and the Law', in J. Razzaque and E. Morgera (eds), Encyclopedia of Environmental Law: Biodiversity and Nature Protection Law. Cheltenham: Edward Elgar.

Tsioumani, E., Muzurakis, M., Ieropoulos, Y. and Tsioumanis, A. (2016) 'Following the Open Source Trail outside the Digital World: Open Source Applications in Agricultural Research and Development', tripleC: Communication, Capitalism and Critique, 14(1): 145-162.

UNCCD Secretariat (2005) Promotion of Traditional Knowledge: A Compilation of UNCCD Documents and Reports from 1997-2003. Bonn: UNCCD.

UN Commission on Legal Empowerment of the Poor (2008) Making the Law Work for Everyone: Vol. 1 - Report of the Commission on Legal Empowerment of the Poor. New York: United Nations.

UN High Commissioner for Human Rights (2003) 'Report on Human Rights, Trade and Investment', UN Doc E/CN.4/Sub.2/2003/9.

UN Human Rights Committee (1994) 'General Comment No. 23: Article 27 (Rights of Minorities)', UN Doc HRI/GEN/1/Rev.1.

UN Secretary-General (2009) 'Legal Empowerment of the Poor and Eradication of Poverty: Report of the Secretary-General', UN Doc A/64/133.

Vermeulen, S. and Cotula, L. (2010) 'Over the Heads of Local People: Consultation, Consent and Recompense in Large-Scale Land Deals for Biofuels Projects in Africa', CCAFS Working Paper. Copenhagen: Challenge Program on Climate Change, Agriculture and Food Security.

Vijge, M. J., Brockhaus, M., Di Gregorio, M. and Muharrom, E. (2016) 'Framing National REDD+ Benefits, Monitoring, Governance and Finance: A Comparative Analysis of Seven Countries', Global Environmental Change, 39: 57-68.

Warriner, D. (1969) Land Reform in Principle and Practice. Oxford: Clarendon Press.

Weatherley-Singh, J. and Gupta, A. (2015) 'Drivers of Deforestation and REDD+ Benefit-Sharing: A Meta-Analysis of the (Missing) Link', Environmental Science and Policy, 54: 97-105.

Wily, L. (2012) 'The Global Land Grab: The New Enclosures', in D. Bollier and S. Helfrich (eds), The Wealth of the Commons: A World beyond Market and State. Amherst and Florence, MA: Levellers Press.

Winge, T., Andersen, R. and Ramanna-Pathak, A. (2013) 'Combining Farmers' Rights and Plant Variety Protection in Indian Law', in R. Andersen and T. Winge (eds), Realising Farmers' Rights to Crop Genetic Resources: Success Stories and Best Practices. Abingdon: Routledge.

Wiggins, S., Kirsten, J. and Llambí, L. (2010) 'The Future of Small Farms', World Development, 38(10): 1341-1348.

Wong, G. Y., Luttrell, C., Loft, L., Yang, A., Pham, T. T., Naito, D., Assembe-Mvondo, S. and Brockhaus, M. (2019) 'Narratives in REDD+ Benefit Sharing: Examining Evidence within and beyond the Forest Sector', Climate Policy, 19(8): 1038-1051.

World Bank (2014) Brazil Land Governance Assessment, Report 89239-BR, Washington, DC: World Bank. 


\section{Moving beyond fair and equitable benefit-sharing}

\section{Trends and challenges}

The preceding analysis provides useful elements for the conceptualization of fair and equitable benefit-sharing in agriculture, and leads to the identification of a series of trends and challenges regarding its application.

When it comes to agricultural research and development, benefit-sharing is a well-established, legally binding policy objective. Having emerged in conjunction with the principle of national sovereignty over natural and genetic resources as reaffirmed in the $\mathrm{CBD}$, fair and equitable benefit-sharing aimed to balance the injustices enshrined in the IPR system by ensuring that some portion of the benefits arising from the use of resources flow back to their providers: biodiversity-rich developing countries and their indigenous peoples and local communities. It thus serves as a tool for the recognition of the stewards of these resources and their reward, in a context of global cooperation in the pursuit of solidarity and justice. It is also conceptualized as a development tool, and a conservation tool. Linked to development purposes and rural livelihoods, it would allow benefits from the emerging biodiversity market to flow to the providers of the raw material for this market; it would also serve as an incentive for biodiversity stewards to enable their continued contribution to biodiversity conservation.

Along these lines, the ITPGRFA has established a highly sophisticated multilateral mechanism to serve the objective of fair and equitable benefit-sharing. Its MLS regulates access to a common pool of crops and forages considered vital for food security and agricultural research, and monetary and non-monetary benefit-sharing arising from the utilization of these resources. The terms for exchange of material in the MLS are provided in the SMTA, a standardized private-law contract between a provider and a recipient (user) of genetic resources, which has been adopted by the Treaty's Governing Body following intergovernmental negotiations.

Under the Treaty, benefit-sharing refers both to the accumulation of benefits from users of the system, and the distribution of benefits back to providers, in this case farmers in developing countries, through projects financed via the Benefit-sharing Fund. This terminological confusion seems to persist across all 
ABS-related fora, including the CBD and its Nagoya Protocol, obscuring the scope of the concept.

Another complication refers to the blurred lines between monetary and nonmonetary benefit-sharing. According to the Treaty, mechanisms for nonmonetary benefit-sharing include exchange of information, access to and transfer of technology, capacity-building, as well as facilitated access to genetic resources in the MLS, which is recognized as a benefit in itself. While these mechanisms are certainly economic in the sense that they involve financial and human resources, monetary benefit-sharing refers strictly to the return of a portion of the gains arising from commercialization of products developed on the basis of material accessed through the MLS. The operation of the Benefitsharing Fund itself serves as an illustration of the interlinkages between monetary and non-monetary benefit-sharing; the distribution of finances serves objectives related to capacity-building and technology transfer, among others, linked thus to non-monetary benefit-sharing. Non-monetary benefit-sharing mechanisms can therefore be used to build the capacities required for use of plant genetic resources and consequently contribute to monetary benefit-sharing. In addition, they are instrumental in addressing the unequal capacities of countries and communities to benefit from the ITPGRFA and use of genetic resources in general, and thus bridging the capacity, fairness and equity gap in agriculture and agrobiodiversity conservation.

Bridging the equity and capacity gap in agricultural research and development is only one of the aspects to be addressed in the struggle for endogenous agricultural development and agrarian justice. Land governance is also of vital importance, but the two fields are rarely studied together. Exploration of benefit-sharing applications offers an opportunity to map and assess international law of relevance to sustainable agriculture more comprehensively.

In this context, farmers' rights provide a preferential field of study, as they are situated at the interface between the regulation of agricultural research and development, and land and human rights. Discussing their origin and rationale, legal basis and implementation challenges, I propose a broad construction of farmers' right to benefit-sharing. This would encompass not only the outcome of benefit-sharing as a process, but also a series of supporting elements and enabling conditions for smallholder farmers, including secure land tenure and access to seeds, as well assistance in the organization of cooperatives and access to markets. Stemming from the ITPGRFA multilateral approach to benefitsharing, this understanding aims both to reward and to enable farmers' contribution to the conservation and sustainable use of agricultural biodiversity and thus to sustainable agriculture and global food security, as global public goods. This twin 'reward and enable' approach to benefit-sharing suggests that farmers should not only be rewarded in monetary terms for their past and present contribution, but should also be supported to continue their practices and contribution to global public goods in the future. Such broad interpretation is further supported by the UN Declaration on the Rights of Peasants, which puts forward a comprehensive approach regarding the rights of rural populations, linking their 
vulnerabilities, their special relationship to land, water, seeds and natural resources and their contribution to global food security, through rights already protected in international law and new - individual and collective - rights.

Looking for traces of benefit-sharing in land regulation is a challenging endeavour. Unlike the area of biodiversity-based research and development, where fair and equitable benefit-sharing is an established international law concept and policy objective, translated into tools and mechanisms for implementation, land governance is still mostly a matter for domestic law. International law emerged relatively recently, mainly with regard to indigenous peoples' rights and human rights in general, environmental sustainability and transnational investment. It was in the context of the 2008 global food crisis and the growing trend of large-scale agricultural investments that land governance became an issue of common concern, of particular importance for food security and human development. In this context, fair and equitable benefit-sharing lacks a consistent normative content and legal bearing across all international instruments of relevance to sustainable agriculture. While still linked to notions of justice and solidarity to the vulnerable, benefit-sharing in land governance is sometimes framed as a policy objective while others as a safeguard. In addition, its international legal basis is usually to be found in non-binding instruments.

In addition to the scope of regulation, there are other fundamental elements that differentiate the regulation of benefit-sharing from land use compared to benefit-sharing from genetic resource use for research and development. The nature of the resource is of particular importance. Land is fixed in supply, and policies are required to accommodate competing uses, overlapping claims and potentially conflicting rights. Restrictions in land use come from both material and legal limitations. Genetic resources, on the other hand, are renewable and easily multiplied, while restrictions in their use stem solely from legal limitations, such as IPRs and ABS laws. A crucial question concerning implementation of benefit-sharing from land use is its relationship with actual access to the resource; the benefit to be shared is often the land itself or the right to use it. Examination of benefit-sharing is thus inextricably linked to redistribution efforts for land or agrarian reform, in view of chronic inequality in land distribution in many countries, complex interactions between formal tenure systems and customary arrangements around the globe and the fundamental question of who has decision-making authority, thus control over land allocation and use.

In this context, the VGGT establish clearly (albeit in a broadly worded manner) a policy objective related to benefit-sharing from public lands, calling on states to strive to develop policies that promote equitable distribution of benefits from state-owned land, fisheries and forests. In addition, redistributive land or agrarian reforms in accordance with the provisions of the VGGT and the UN Peasants Declaration can be considered a tool for benefit-sharing, aiming to share not only the benefits arising from the resource but also the resource itself.

When it comes to governance of public lands, application of benefit-sharing considerations may be used to promote fair and equitable use of public lands 
through systems of concessions for the use of uncontested public land by individuals or farmer cooperatives for food security and rural livelihoods objectives, and through procedural and substantive safeguards against arbitrary or unfair interference with local land rights, including in the case of large-scale agricultural investments. This conceptualization is supported by elements enshrined in the VGGT and other soft-law instruments, and illustrated by human rights jurisprudence.

Benefit-sharing considerations have been forwarded in the form of safeguards in the case of large-scale agricultural investments, although questions remain regarding the relationship between benefit-sharing and land-use rights, particularly customary ones. That is, empirical research shows that, in many cases, doubtful or strictly monetary benefit-sharing arrangements tend to replace legitimate land-use rights, with detrimental effects for livelihoods and social cohesion. Contrary to its original intent, benefit-sharing can thus be used to reproduce injustices and impose dominant ideological, economic and development models. Literature on the actual implementation of benefit-sharing arrangements via either policy interventions or contractual provisions remains limited, illustrating the need to bridge the gap in legal commentary and provide a comprehensive picture of the socio-legal framework and its implementation on the ground, from the international to the national and the local level.

That said, two issues are of particular relevance for the study and conceptualization of fair and equitable benefit-sharing in the case of large-scale agricultural investments: the potential mismatch between macro-level benefits at the government level and negative impacts on local-level livelihoods, resulting in unfair distribution of risks and benefits; and procedural shortcomings in the design and implementation of such agreements, due to a series of structural considerations related to national frameworks characterized by poor governance. Traditional legal tools such as impact assessments can be used to build the enabling conditions and allow for meaningful identification and sharing of benefits arising from an investment or development.

In this context, benefit-sharing considerations can come into play as follows: as opportunities for meaningful participation and recognition of legitimate right holders in the decision-making process; in terms of safeguards for local land rights against arbitrary or unfair interference, to be included in the cost-benefit assessment process; and finally in the form of contractual arrangements for revenue-sharing and non-monetary benefits such as infrastructure development. The concept thus again needs to be understood and constructed broadly in the context of the VGGT, which provide guidance both on the protection of legitimate tenure rights and on mechanisms for transparency, participation and accountability in decision-making regarding land allocation.

The overall analysis supports that the concept of fair and equitable benefitsharing has the potential to contribute to sustainable agriculture and rural livelihoods objectives if constructed broadly to cover both the process for its achievement, including supporting elements and enabling conditions, and the substantive outcome. In this sense, benefit-sharing should be understood as 


\section{Beyond fair and equitable benefit-sharing}

integrating mechanisms for information sharing, technology transfer and capacity-building, dubbed as non-monetary benefit-sharing in the research and development realm, and mechanisms for transparency, participation and accountability in decision-making regarding land allocation and use. Enabling conditions, including an inclusive process, are prerequisites for a fair and equitable outcome. Focusing only on expectations for monetary benefits, intergovernmental negotiations, including under the ITPGRFA as well as other ABS-related fora, seem to lose this point. This is, however, easily explained, within the current neoliberal context and the resulting growing global inequities associated with trade liberalization, expansion of IPRs and corporate control over agriculture.

The legal architecture supporting application of fair and equitable benefitsharing lies in environmental treaties, and human rights- and agriculture-related instruments. It co-exists with a series of trade- and investment-related agreements which do not support benefit-sharing considerations, within an increasingly hostile and inequitable political and economic landscape which promotes a neoliberal model of growth. Adoption of the TRIPS Agreement weakened the gains associated with the $\mathrm{CBD}$, while an ever-growing web of bilateral and multilateral free-trade and investment agreements reduces policy choices for developing countries through IPR-related standards and land-related developments.

The gradual strengthening of plant breeders' rights and the expansion of patents aggravate the asymmetry between modern and farmers' varieties, and limit the discretion of states that wish to safeguard agricultural systems that rely upon small-scale farming with well-documented impacts on local food security and rural livelihoods. But it is large-scale investments in farmland that are considered among the main factors threatening rural livelihoods, radically transforming not only customary tenure systems but also formally recognized ones. One of the key trends that emerged out of the 2008 global food crisis, large-scale land investments by both national and international corporations have been increasing the risk of dispossession for vulnerable rural populations. The expanding sphere of application of international trade and investment law, in combination with its enforcement potential and the asymmetry in capacities and power of the parties involved, has resulted in protection of the international capital, often to the detriment of national development priorities in developing countries, restricting states' ability to regulate for the public interest. Imbalances in the law raise questions about whose rights are being prioritized and why.

As long as 15 years ago, the Sub-Commission on Human Rights had already drawn attention to the primacy of human rights obligations over economic policies and agreements and requested the TRIPS Council to take fully into account existing state obligations under international human rights instruments. In the meantime, the international community seems to be taking the opposite direction. The WTO dispute settlement system is being used at full speed to enforce implementation of multilateral trade agreements, often against developing countries' efforts to provide food security for local populations; the 
activities of multinational companies remain largely outside the scope of international law (De Jonge 2011); a complex web of bilateral and regional trade and investment treaties build a WTO-plus legal order enforced through arbitration tribunals, which limit national governments' regulatory choices outside whichever guarantees of equity and legitimacy multilateralism provides (Cotula 2014). Trade- and investment-oriented policies are gaining a de facto supremacy over human rights and environmental treaties, because of their enforcement potential and the underlying power of actors and interests involved. At the same time, the dramatic extent of patent expansion and market concentration means that enforcement of IPRs is not even needed, as 'the dominant oligopolists are in a position to dictate to farmers the very conditions of access to seed' (Kloppenburg 2014: 1229), at the same time making public research on novel technologies virtually impossible (Tsioumani et al. 2016).

\section{Lessons from the grassroots}

While the overall picture of international law appears rather gloomy at the moment, with the dominant growth model being coupled with growing nationalisms, rising authoritarianism and a mistrust of multilateralism, the escalation of civil society and grassroots movements provides rays of hope.

The preceding analysis has showcased the role of movements in the development not only of national but also of international law. Several land rights movements around the globe demand land redistribution, claim recognition of customary, in cases communal, rights to land and assert the right to control the type of development undertaken as a means towards social and agrarian justice. In Brazil, a country with chronic problems related to extreme land concentration, policy developments were shaped by the struggles of the Brazilian Landless Rural Workers' Movement (MST), one of the most active social movements in the region, known for its massive land occupations. MST has launched the Popular Agrarian Reform, a new model of agrarian reform which links land distribution demands with governance based on food sovereignty and agro-ecology (Azevedo 2016), with documented impact on the country's land governance profile.

Agrarian movements have recently been a driving force behind international law development. Lorenzo Cotula (2016) notes, for instance, the significant contestation against land acquisitions, which has given rise to local-to-global alliances of affected people, social movements and NGOs opposing the deals. The impact of such movements to the development of international law has been reflected most prominently in the adoption of the UN Declaration on the Rights of Peasants. La Via Campesina had a leading role in the negotiations, representing a rare case of direct involvement of social movements in international lawmaking. In fact, Priscilla Claeys and Marc Edelman (2019: 1) characterize the process of development of the Declaration as 'a new kind of people's diplomacy and an innovative, bottom-up process of building alliances, lobbying, and authoring international law'. Importantly, the Declaration 


\section{Beyond fair and equitable benefit-sharing}

elaborates on the right to land and to the sustainable use of natural resources, including fair and equitable benefit-sharing in any case of exploitation affecting such natural resources. Further integrating references to seed-related rights, food sovereignty and agrarian reforms to facilitate broad and equitable access to land and other natural resources, the Declaration, alongside the VGGT, could potentially impact the development paradigm, by building upon their emancipatory potential to draw attention to peasant autonomy and the broader agrarian struggles for social justice.

In this context, in the next chapter I explore a series of case studies illustrating community-level understandings of benefit-sharing. Of diverse origin, size, focus and visibility, these initiatives illustrate the sharing ethos at the heart of the concept of fair and equitable benefit-sharing, which could affect the acceptability and legitimacy of policy action, within or beyond strict legal frameworks.

\section{References}

Azevedo, C. (2016) 'Gaining Land and Gaining Ground? The Popular Agrarian Reform by the Landless Rural Workers' Movement (MST) in Brazil', Paper no. 52: International Colloquium on Global Governance/Politics, Climate Justice and Agrarian/ Social Justice: Linkages and Challenges, available at: www.iss.nl/sites/corporate/files/ 52-ICAS_CP_Azevedo.pdf (last accessed 13.12.2019).

Claeys, P. and Edelman, M. (2019) 'The United Nations Declaration on the Rights of Peasants and other People Working in Rural Areas', The Journal of Peasant Studies, early electronic publication, DOI: 10.1080/03066150.2019.1672665.

Cotula, L. (2014) 'Do Investment Treaties Unduly Constrain Regulatory Space?', Questions of International Law, Zoom-in, 9: 19-31.

Cotula, L. (2016) “'Land Grabbing” and International Investment Law: Toward a Global Reconfiguration of Property', in A. K. Bjorklund (ed.), Yearbook on International Investment Law and Policy. Oxford: Oxford University Press.

De Jonge, A. (2011) 'Transnational Corporations and International Law: Bringing TNCs out of the Accountability Vacuum', Critical Perspectives on International Business, 7(1): 66-89.

Kloppenburg, J. (2014) 'Re-Purposing the Master's Tools: The Open Source Seed Initiative and the Struggle for Seed Sovereignty', The Journal of Peasant Studies, 41(6): 1225-1246.

Tsioumani, E., Muzurakis, M., Ieropoulos, Y. and Tsioumanis, A. (2016) 'Following the Open Source Trail outside the Digital World: Open Source Applications in Agricultural Research and Development', tripleC: Communication, Capitalism and Critique, 14(1): 145-162. 


\section{Exploring grassroots initiatives from the seed to the landscape}

\section{Introduction}

This chapter explores four examples coming from the grassroots, which enrich the concept of fair and equitable benefit-sharing, offering ideas for institutional and legal innovation:

- the concept of participatory plant breeding, aiming to re-involve farmers in plant breeding;

- open-source applications in agricultural research and development, with a focus on the Open Source Seed Initiative;

- the Peliti community in Greece, a network of local groups working on the conservation and exchange of traditional varieties; and

- the case of the Potato Park in the Peruvian Andes, which is an indigenous biocultural heritage area based on a sui generis legal system combining customary laws with concepts of international environmental law.

The four selected case studies seek to cover a broad range of aspects, actors and approaches involved in agricultural biodiversity conservation, agricultural research and development and land management for sustainable agriculture and food security. They range from the seed to the landscape and from amateur gardeners and indigenous peoples to professional farmers and public-sector researchers.

\section{Participatory plant breeding}

Participatory plant breeding is a general term used to describe a broad range of collaborative programmes involving both scientists and farmers in plant breeding (Westengen and Winge 2019). The approach was developed in response to the shortcomings of scientific, professional plant breeding, which was evolved to support the objectives of the green revolution and was centralized around the international agricultural research centres of the CGIAR (Morris and Bellon 2004). As explored in the first and second chapters, the emergence of professional plant breeding and the commercial seed sector led to 
the marginalization of farmer practices and seed systems. As a result of a series of trends, including the professionalization of plant breeding, formalization of seed markets and structural adjustment programmes, farmers became more dependent on commercial seed providers and vulnerable in view of higher seed prices; importantly, they also became mere end-users of seed, rather than innovators, gradually lost knowledge and confidence in their capacities and were disempowered vis-à-vis other sectors of society (Westengen and Winge 2019; Salazar et al. 2019).

At the same time, the largely centralized modern plant breeding system failed to address the enormous diversity of environmental conditions and the needs of farmers around the world, particularly when it comes to subsistence-oriented farming systems. Especially in the context of reduced public investment in agriculture in many countries around the world (Manzella and Louafi 2019), efforts focused more on major food crops of economic and political importance such as wheat and rice, leaving aside traditional food crops consumed mainly in developing countries, such as minor grains, tubers and pulses (Morris and Bellon 2004), which, however, are of great value for food security and nutrition, and the needs of subsistence farmers living in marginal environments. Recognition of this reality led to the establishment of a number of pilot projects in the 1990s, including under the umbrella of the CGIAR, which involved farmers in various stages of the breeding process: from setting objectives, and testing and selecting breeding materials in their own fields, to building farmers' skills to breed their own varieties (Almekinders and Hardon 2006).

In an early analysis of participatory plant breeding research, Michael Morris and Mauricio Bellon (2004) underscored the benefits of integrating global and local plant breeding efforts through participatory plant breeding programmes with regard to agronomic outputs. They noted that the international plant breeding system has largely bypassed the needs of farmers in marginal environments in developing countries who grow mainly non-commercial food crops, leaving them vulnerable to periodic production shortfalls and chronic food insecurity. Participatory plant breeding methods, they argue, have the potential to deliver better varieties to address their needs. More recent research, however, has pinpointed the objectives of participatory plant breeding in areas much broader than improved and more focused productivity. Daniele Manzella and Sélim Louafi (2019) note that participatory plant breeding involves a compromise between utilitarian and fairness-oriented views of collaboration; it implies balancing the interests of different stakeholders and relates to the effectiveness of legal measures for safeguarding those interests. Pointing to the unfair distribution of benefits and costs of the green revolution and arguing there is no such thing as an apolitical agronomy, Ola Westengen and Tone Winge (2019) argue that plant breeding must address dimensions of sustainability and farmer empowerment, in addition to productivity, in order to relate to the 2030 Sustainable Development Agenda with regard to the development of sustainable agri-food systems. Rene Salazar and colleagues (2019) go further; exploring human development and social reform perspectives of participatory plant 
breeding, they argue it should not address only the technical challenges of managing and improving the local crop and variety portfolio used by farmers. It must take into account the socio-economic and political context, to address social inequities, improve livelihoods and aim for greater empowerment. For Salazar and colleagues, participatory plant breeding should focus on maintaining not the traditional cultivars per se, but farmer-based innovation and seed systems as a structural component of agricultural development, centred around gender sensitivity and co-development of knowledge. Farmers should participate in the creation of new varieties that are best adapted to their socio-economic realities and agro-ecological conditions, reducing dependency, building confidence and inserting diversity in the production system (Salazar et al. 2019; African Centre for Biodiversity 2018). Participatory plant breeding thus cannot be assessed solely in terms of new varieties produced, but also in terms of social benefits, including empowerment and organizational capacity (Manzella and Louafi 2019).

Challenges regarding participatory plant breeding involve a host of participation-related issues such as inclusiveness, choice of participants, addressing gender issues and building a common language to accommodate the knowledge and experiences of all participants, farmers and conventional plant breeders alike. With regard to outcomes, designers and participants would also need to address the type of monetary and non-monetary benefits to be achieved, including, for instance, more resilient or more productive varieties, higher incomes or new knowledge - agronomy- or policy-related (Winge 2019). In addition, a series of legal, institutional and financial challenges are of particular importance for the purposes of this analysis.

Although the literature has gradually acknowledged the potential of participatory plant breeding programmes towards improved productivity, sustainability and empowerment outcomes, recognition of such potential by policy fora remains limited. The FAO Voluntary Guide for National Seed Policy Formulation, ${ }^{1}$ developed to assist governments in formulating policies which help create an enabling environment for seed sector development, recognizes the role of informal seed systems, and calls for building linkages between variety development, seed production and distribution, as a means to ensure that farmers have easy access to new and adapted varieties. This can be achieved through participatory plant breeding and participatory varietal selection and the active involvement of farmers, particularly women, in these processes. Participatory plant breeding has also been attracting attention under the ITPGRFA as an approach promoting implementation of farmers' rights, including to fair and equitable benefit-sharing, as well as the Treaty's provisions on sustainable use of plant genetic resources. Tone Winge (2019) notes that participatory plant breeding utilizes farmers' traditional knowledge, thus contributing to its protection through use, brings benefits to farmers and can empower them to participate in decision-making and get familiar with legislation and policies that affect them. In her examination of resolutions and other instruments adopted under the Treaty, she draws attention to references to participatory plant breeding as a 
means towards sustainable use of plant genetic resources in a resolution adopted by the Treaty's Governing Body (Resolution 4/2015) as well as in the Toolbox for Sustainable Use of PGRFA. This toolbox is an online system developed to assist countries in designing and implementing measures to promote sustainable use of PGRFA, built to reflect the needs of all stakeholders involved in different aspects of PGRFA utilization. ${ }^{2}$ She further highlights recognition of participatory plant breeding as a tool for realizing farmers' rights, alongside community seed banks, biodiversity registers and seed fairs (Resolution 7/2017), adding that the Global Consultation on farmers' rights undertaken in the Treaty framework in 2010 revealed that it was among the most widely employed and favourably viewed measures for benefit-sharing (Winge 2019).

In practice, however, many participatory plant breeding programmes receive little or no official policy or legal support for production and distribution of varieties. Most countries' seed laws and regulations fail to recognize the importance of informal seed systems and do not support participatory plant breeding efforts, due to requirements related to seed certification and marketing, limitations in seed exchanges and strict variety registration procedures for seed producers excluding farmers (De Jonge et al. 2019). Bram De Jonge and colleagues (2019) draw attention to policy measures implemented in some countries to accommodate such efforts, including exemptions to general seed legislation, opportunities for registering farmers' varieties and the introduction of an 'alternative seed class', which is regulated specifically to support the production, use and marketing of seed of farmers' varieties resulting from participatory plant breeding programmes. As explored in detail in the second chapter, however, implementation of both opportunities for registration and exemptions to seed certification and marketing requirements for farmers' varieties is largely problematic. De Jonge and colleagues also conclude that such alternative approaches aiming to support farmers' varieties need further development, upscaling and investment.

Supportive legal measures are thus needed, with regard both to access to source germplasm and recognition of the outcome of participatory plant breeding as collective innovation, including keeping it available for further research and development (Manzella and Louafi 2019). When it comes to access to source material, participatory plant breeding programmes need to ensure its legal status allows its use in the programme. If this material is protected by IPRs, this means either benefiting from the breeder's exemption or requesting the holder to waive them for the purposes of the programme, which may involve significant challenges as noted under the case study on open-source applications. If the material comes from a public or CGIAR collection, rules under the CBD or the ITPGRFA may apply. Legal recognition of the outcome of participatory plant breeding in the current IPR context is also complicated, because of difficulties associated with applying the criteria of plant variety protection and granting rights to a community for collective innovation, particularly in view of the diversity in forms of collaboration and outputs experienced in participatory plant breeding projects. An additional challenge would be to maintain the availability of the outcome for further research and breeding. This could be achieved 
by either making it available to the ITPGRFA Multilateral System voluntarily, as practised by participatory plant breeding programmes funded by the Treaty's Benefit-sharing Fund (Toledo 2019), or using open-source models (Manzella and Louafi 2019), which are explored in more detail below in this chapter. Manzella and Louafi (2019) argue that the open-source logic may be particularly appropriate for participatory plant breeding programmes, as it focuses on community management for both the creation and the sharing of intellectual and cultural resources not necessarily incorporated in the final biological output - the improved variety.

In view of lack of legal and institutional support, and decreasing public investment in agriculture, financial sustainability is another crucial challenge for participatory plant breeding programmes. Participatory plant breeding projects feature prominently in the grant portfolio of the ITPGRFA Benefit-sharing Fund, as they support the Fund's priorities regarding on-farm management, sustainable use, information exchange, capacity-building and technology transfer (Toledo 2019). Álvaro Toledo (2019) reports that 27 participatory plant breeding projects have been funded during three project cycles of the Benefit-sharing Fund, further noting that partners have highlighted the multi-sectoral and community-based nature of such projects, which work directly with targeted rural communities to ensure that interventions are based on local needs, collective strengths and shared resources.

While funding from the Benefit-sharing Fund is certainly an acknowledgement of the value and contribution of participatory plant breeding projects to the Treaty's objectives, and may eventually promote institutional recognition and policy support, it cannot cover funding needs in a predictable and sustainable manner. For years, the international agricultural research centres of the CGIAR, along with donor countries, NGOs and national research institutes, have also played a key role in supporting such projects with varying specific objectives, ranging from increased production and enhanced adoption of suitable varieties to biodiversity conservation and enhancement of farmers' own breeding efforts. Conny Almekinders and Jaap Hardon (2006) record and assess several relatively early case studies. Some of them, they note, are more focused on varietal improvement and design of breeding activities, while others prioritize supporting farmers' capacities to manage their own genetic resources as a form of empowerment. A project in Mali was initiated by plant breeders of the International Crops Research Institute for the Semi-Arid Tropics (ICRISAT), a CGIAR centre, and aimed at creating a breeding programme that could more effectively develop varieties that are attractive to farmers. It involved setting breeding objectives based on farmers' priorities and developing materials for variety selection on community lands. Farmers were involved in selecting material for on-farm testing trials, which they then managed and recorded. These trials led to a number of promising varieties which were selected for larger-scale trials, while farmers outside the project areas also showed great interest.

The Community Plant Genetic Resources Conservation and Development Project in Vietnam was one of the projects under the Community Biodiversity 
Use, Conservation and Development in Asia Programme (BUCAP), coordinated by an NGO, the Southeast Asian Regional Institute for Community Education (SEARICE) and funded by Norway's Development Fund. The main objective of BUCAP was providing farmers with knowledge and methodology to conserve and diversify plant genetic resources at community level, through farmer field schools and field studies. Implemented in Vietnam, Laos and Bhutan, its focus was to address the narrowing rice genetic diversity in Asia and the inadequate participation of farmers in agricultural development. The Vietnam programme is recalled as an example of a participatory plant breeding approach where farmers have the most control over the process. Implemented in a range of environments, including both rain-fed and irrigated rice production, reports account participation by 2519 farmers (1169 women and 1350 men) in 48 villages (Almekinders and Hardon 2006). Successes included the development of four varieties in two different villages. More generally, increase of farmers' access to a wider range of varieties and of variety diversity in farmers' fields led to rehabilitation of local varieties through mass selection and yield increases of more than $20 \%$, increasing the diversity and quality of national rice production. The high level of farmers' organization in communes and their familiarity with farmer field schools are mentioned as important factors contributing to the programme's success. Almekinders and Hardon (2006) note that, despite problems with regard to access to suitable parental materials for crosses and compliance with national rules and regulations, the ability of farmers and their organizations to play a meaningful role in breeding, selecting and producing seed is well established, and needs to be integrated in national policies.

The Bhutan programme also focused on empowering farmers and strengthening farmer seed systems. It was linked to a prior breeding programme aimed at developing resistance against a severe rice blast epidemic at high altitudes, which involved crosses between modern varieties and local landraces and screening in various rice growing regions. Adopting a farmer field school approach as in Vietnam, the programme promoted self-reliance in decision-making and revitalized farmers' confidence in managing their genetic resources (Almekinders and Hardon 2006). Farmers were first involved in screening breeding lines for blast resistance and local adaptation. The project was then expanded to improving uniformity and productivity of local landraces of rice and maize, leading to a real partnership between farmers and plant breeders.

Farmer field schools have been successfully used in many cases and proved to be a highly suitable instrument for socially and gender-inclusive participatory plant breeding and method for empowering farmers, giving recognition to their knowledge and affirming their capacity for innovation. Farmer field schools allow farmers to collectively learn to define problems, seek solutions and set targets, and, with the support of scientists and extension staff, learn breeding and selection approaches, test the seeds of new varieties and share their observations on these seeds. In Vietnam, for instance, largely as a result of participatory plant breeding efforts in farmer field schools, farmers have established over 400 seed clubs, providing some $25 \%$ of certified rice seeds of the 
Mekong Delta (Salazar et al. 2019). Farmer field schools are also the main tool used by the Oxfam-coordinated Sowing Diversity $=$ Harvesting Security programme, ${ }^{3}$ which is one of the largest programmes currently facilitating participatory plant breeding projects. Rather than simply sharing technology, or training farmers to produce seeds for distribution to other farmers, the programme claims its focus is on people's capacities for self-organization and mutual learning in order to create locally adapted crop varieties and engage in changing government policies. Working towards a 'fair, sustainable and genderjust global food production system', the programme is organized around four interconnected pillars. It scales up its impact by promoting free use of its outcomes; it also promotes farmer seed enterprises in the form of seed production and marketing cooperatives of various sizes, organizational structure and market engagement, which aim at providing smallholders in diverse and stressful production areas with well-adapted appropriate varieties of highquality seeds, improving the diffusion of farmers' varieties and increasing availability of plant genetic diversity in wider seed markets. Community seed banks are set up, to keep seeds available at the community level over growing seasons, while seed fairs serve as platforms for sharing seeds, knowledge and experiences. The programme further empowers women to reclaim their role in food and nutrition security through strengthening their capacity in seed management and global policy engagement, and strengthens the knowledge base with regard to relevant policy and legislation, by connecting experiences from the community level with national and global policymaking to empower farmers' engagement with relevant policymaking.

\section{Open-source applications in agriculture}

As noted above, plant breeders need to ensure the legal status of the source material they use in their research programmes. ${ }^{4}$ Researching and negotiating the IPRs that potentially surround the material and methods of their work in order to obtain 'freedom to operate' may be a substantial transaction cost for breeders (Kloppenburg 2014). This is particularly due to the breadth of patents currently granted, as explored in the first chapter, and the uncertainty generated by patent applications that are still pending, as well as the fees usually required for searching patent databases. The obscurity of the patent landscape is further exacerbated by the fact that, while ownership of the patent is usually a matter of public record, ownership of the rights transferred through licenses is not. Most jurisdictions do not impose a responsibility on licensees to disclose, making it almost impossible for a researcher to assemble all the licenses needed to proceed with her research (Jefferson 2006). In an inversion of their intent, IPRs are used to obstruct research and impede innovation; in the possibility only of patents and pending patent applications on material and methods they may use, breeders are advised not to proceed with their work out of fear of litigation and the cost involved, even if the patent claims are likely not defensible in court (Kloppenburg 2014). 
The effects of the widespread patenting of germplasm, research technologies and breeding methods have been characterized as a 'tragedy of the anticommons' (Heller 1998; Heller and Eisenberg 1998). As noted in the second chapter, Heller's tragedy of the anticommons refers to a situation where too many parties hold a right to exclude with respect to a particular property or resource, leading to the need to obtain several permissions for use.

An often-cited example illustrating the complexity and obscurity of the patent landscape is that of Golden Rice, a genetically modified rice variety heralded as a potential solution to vitamin A deficiency. A detailed analysis of the intellectual property dimensions documented approximately 70 patents and pending patent applications implicated in its development. The high media profile of the case facilitated negotiations with the patent holders. Humanitarianuse licensing was applied, an otherwise rarely used tool which allows for humanitarian uses of proprietary technologies to support international development objectives (Aoki 2009).

Such multi-level complexity has devastating consequences for public breeders, particularly in developing countries, including for underfunded research on neglected crops relevant for local food security. In the context of a complex and contradictory international legal framework, characterized by primacy of trade-related concerns and IPR enforceability, as explored in the previous chapters, and a socio-economic reality defined by the power of the commercial agro-chemical sector, certain initiatives started experimenting with novel tools inspired from developments in the sector of information technologies (IT), in particular open-source.

Open systems have long been associated with the practices of science and academia. 'Open-science' systems facilitate knowledge production through disclosure, sharing and reciprocal exchange, while relying on a system of public expenditures (Louafi and Welch 2014). In the current increasingly proprietary environment for material and non-material resources of scientific significance (Benkler 1999; Boyle 2003), the open-access movement promotes public-sector values by advocating the removal of access barriers to academic research. In synthesizing a wealth of relevant literature, Sélim Louafi and Eric Welch usefully argue that the open-access movement represents a political response, seeking to democratize access to knowledge and innovation; it has been expanded by more recent open-data initiatives, which refer more specifically to data and information that can be used for research purposes. Open-source, on the other hand, refers to an economic response to information enclosures, and proposes an alternative model aiming to implement and manage open systems, in order to enhance production and innovation. Open-source is thus linked to legal and organizational rules meant to control activity and outcomes (Louafi and Welch 2014). In this context, open-access systems and concepts are closer to the idea of the public domain, in the sense that nobody is excluded from use, while open-source models are closer to the concept of protected commons, as they are open to a group of users and specific rules for access and sharing, including restrictions, apply (Louafi and Welch 2014). Similarly, while open-access efforts 
maintain a flexible approach to the systemic inclusion of IPRs, open-source relies on IPRs and licensing terms to establish and operationalize open systems.

The open-source concept has its origin in the IT sector. When software was produced mainly by academia, it was distributed freely under the principle of cooperation, together with the source code - the human-readable version of a programme. By the late $1960 \mathrm{~s}$, increased complexity led to increased production costs, which in turn led to commercialization and imposition of restrictions upon redistribution. By the early 1980s, charging for software licenses had become mainstream and copyrights and trademarks were widely enforced (Weber 2004). In addition, to prevent software from being used on their competitors' computers, most manufacturers stopped distributing the source code and began using copyright and restrictive software licenses to limit or prohibit copying and redistribution.

While many online communities were still building and sharing software, in 1983, Richard Stallman published the GNU Manifesto. With this, he started actively defending knowledge-sharing practices against the rise of software as a commodity. The GNU Project that was launched simultaneously had the goal of creating an open-source operating system. Two years later, Stallman had created the Free Software Foundation to support the free-software movement, which was based on the philosophy that use of computers should not prevent cooperation. In practice, this means rejecting proprietary software, which imposes such restrictions, and promoting free software (Stallman 2004). To protect the result of the work of free-software communities and the GNU Project, Stallman published the GNU General Public License (GPL) in 1989. The GPL is the most widely used free-software license (Black Duck Software 2015), which guarantees end users the freedom to run, study, share (copy) and modify the software. It is a copyleft license, which means that derived works can only be distributed under the same license terms.

As evident by the existence and content of the manifesto, the free-software movement was a political response to the diminishing freedoms of computer users. Stallman deems IPRs to be an overgeneralized term including different sets of rights under one umbrella, and carrying 'a bias that is not hard to see: it suggests thinking about copyright, patents and trademarks by analogy with property rights for physical objects' (Stallman 2006). Along the same line of thought, in their seminal work, economists Michele Boldrin and David Levine prefer the term 'intellectual monopoly' as a more appropriate and clear definition of the concept, which, they argue, is very dissimilar from property rights (Boldrin and Levine 2005). Thus, according to Stallman and contrary to the IPR philosophy, free software will promote rather than hinder progress in technology (Stallman 1985).

Many members of sharing communities, however, did not share Stallman's vision. Distancing themselves from the notions that non-free software is a social problem or unethical, they argued that sharing practices should continue for reasons rather related to technological superiority, innovation and economic growth. In this context, members of the free-software movement founded the 
Open Source Initiative in 1998, shortly after the announcement of the release of the Netscape source code. They believed that the pragmatic, business-case grounds that had motivated Netscape to release their code illustrated a valuable way to engage with potential software users and developers, and convince them to create and improve source code by participating in an engaged community. They created the 'open-source' label to identify this approach and distinguish it from the philosophically and politically focused 'free software' (Open Source Initiative 2012). Currently, the term 'Free and Open Source Software' (FOSS) is commonly used to include both practices. FOSS is produced and distributed either by informal communities and non-profit organizations or as commercial products by corporations, with Linux, Android and Firefox as notable examples. Despite the free-software-versus-open-source ideological schism, the overwhelming majority of open-source programmes are also compatible with the free-software modalities and vice versa.

As awareness was growing that the FOSS paradigm is not limited to software and that 'it can potentially be applied in any domain that requires a team of thinkers to tackle a problem' (Schweik 2007: 302), several analysts proposed applying the open-source principles and practices to plant breeding and the seed sector. The idea emerged more or less independently from a variety of disciplines, as Jack Kloppenburg notes on the basis of a literature review: plant breeding, molecular biology, sociology and law (Kloppenburg 2014). The main rationale was that in a legally defined space in which sharing is unimpeded by IPRs, farmers can continue to apply their local knowledge, in equitable cooperation, and public researchers can continue with scientific plant breeding in the face of global challenges. The open-source idea was considered promising, both as a defense against IPRs and as a potentially successful commercial model leading to sustainably funded projects.

The extent to which open-source models can be applied to agriculture is subject to debate. An open-source model in the agricultural sector would be based on the idea that farmers are both users and developers of both plant varieties and the related information, knowledge and technology. New plant varieties and related technology developed using a participatory process could be made available to farmers and plant breeders with a GPL-styled license with the same viral effect; any subsequent modifications must be openly accessible under the GPL terms, on a contractual promise that there would be no downstream restrictions on the rights of others to experiment, innovate, share or exchange the plant genetic resources. Application of the model would entail an inclusive user community of farmers, plant breeders and researchers through which information and technology may be exchanged freely via decentralized commons-based peerproduction networks (Aoki 2009). Keith Aoki (2009) optimistically argues that such a model would lead to increased capacity of users, rather than creating passive consumers of technologically advanced but legally inaccessible crop technology systems. It would also enable farmers to continue developing plant varieties adapted to particular local situations, and thus prevent genetic erosion. In addition to creating a system allowing for open exchange of knowledge and 
innovation, the motivations for using an open-source model in the agricultural context are further linked to addressing global challenges related to food security, conservation of agricultural biodiversity and rural development.

Following the proposal for a GPL for 'Plant Germplasm' by plant breeder Thomas Michaels in 1999, the Open Source Seed Initiative (OSSI) represents one of the most notable examples of application of the open-source concept in plant breeding. The idea for OSSI emerged from two meetings held in the USA in April 2010 and May 2011, which were attended by a small number of public and private plant breeders, farmers and NGOs' and indigenous groups' representatives. The idea was to encourage and reward the sharing rather than the restriction of germplasm, revitalize public plant breeding and integrate the skills and capacities of farmer breeders with those of plant scientists. OSSI was eventually founded in 2012 as a USA-based not-for-profit organization, focusing on establishing a protected commons of open-source varieties and on educational and outreach activities associated with the development of this open-source seed commons, seed rights and issues related to the control of seed.

The initiative's basic aims included: development of a germplasm licensing framework with no breeding restrictions on the germplasm released through its auspices other than that derivatives must also be released with the same license; participatory plant breeding through integration of the skills of farmers with those of plant scientists; respect for the rights and sovereignty of indigenous communities over their seeds and genetic resources; development and maintenance of a plurality of sources from which farmers and breeders can obtain seed; and support for a public and community plant breeding sector (Kloppenburg 2014).

A key tool for achieving these goals was the development of open-source licenses, modelled on legal arrangements successfully deployed in the software realm, which preserve the right to use material for further breeding and the right of farmers to save and replant seed (Kloppenburg 2014). Arrangements proceeded on the basis of two such licenses, with the accompanying copyleft requirements: one was 'free' with the only restriction that licensees may not restrict the freedom of others to use the seed in whatever way they wish; and the other was 'royalty-bearing', allowing collection of royalties on the seed but not restricting usage in any other way. These two licenses aimed to accommodate two tendencies manifest within the Initiative: one supporting completely free access to seed and rejecting any commodification of life forms, coming mainly from farmers from the Global South; and one interested in some returns or rewards through royalties, coming mainly from breeders in the North, who looked for revenues to maintain their programmes, in view also of the declining public financial support. This schism between farmers and breeders reflected not only the different needs between two societal sectors, but also the difference between still existing subsistence-based agricultural economies of the South and market-based economies of the North.

According to Jack Kloppenburg, one of OSSI funders, one of the immediate difficulties was a technical legal one. The initiative struggled over repurposing 
contract law and drafting copyleft licenses that would be maximally defensible in court, resulting in 'seven pages in language that none but an attorney can understand' (Kloppenburg 2014: 1240). The need for such a license to accompany every package of seed sold or exchanged resulted in inflexibilities, and a failure to virally propagate, negating the most powerful feature of the opensource approach. OSSI eventually decided to use an informal pledge printed on every seed packet or transmitted along with the seed.

You have the freedom to use these OSSI-Pledged seeds in any way you choose. In return, you pledge not to restrict others' use of these seeds or their derivatives by patents or other means, and to include this Pledge with any transfer of these seeds or their derivatives. ${ }^{5}$

The OSSI would thus continue to implement a protected commons mechanism through a chain of bilateral commitments (Manzella and Louafi 2019), but in the form of a pledge not to restrict use of the material or derivatives thereof rather than licenses. The OSSI pledge would operate rather as an ethical commitment from seed users to comply with the open-source rules and engage in the sharing of plant genetic resources (Kotschi and Horneburg 2018). This arrangement bypassed the undisputable difficulties of repurposing contract law and increased the viral potential of OSSI seeds, but arguably reduced the legal enforceability of the copyleft requirement (Hamilton 2014).

Johannes Kotschi and Bernd Horneburg (2018) draw attention to other attempts to apply the open-source concept, including the Open Source Seed License, developed by a working group of agricultural scientists, plant breeders and lawyers under the auspices of the German NGO Agrecol. The license was developed and published in 2016 following a comparison of ethical approaches based on a pledge and legal approaches based on a license, and with the aim to promote enforceability in the EU.

\section{The Peliti community}

The Peliti community was established in 1995 as a non-profit organization under Greek civil law. ${ }^{6}$ Its aims include: the collection, conservation and distribution of traditional agricultural varieties; the non-monetary exchange of goods and services; and the creation of a community focusing on conserving traditional varieties, including the preservation of seed saving-related knowledge, as well as local animal breeds. Based in Messochori, in the area of the virgin forest around Paranesti in northern Greece, and founded by Panagiotis Sainatoudis, it started as a personal effort that gradually got bigger, resulting in the creation of 20 local seed groups operating in various locations around Greece, one in Bulgaria and one in the USA. It unites both food producers and amateurs with an interest in seed collection and preservation and the objectives of the community in general. Members may join for different reasons, such as the passion for the seed, the quest for healthy food, or the desire for participation in general. 
Peliti's activities include seed collection expeditions in mainland and island Greece, free distribution of seeds by post and yearly festivals for seed exchanges and seed distribution. These festivals are considered to be among the most popular globally, with thousands of visitors every year coming from Greece and abroad. The community is also engaged in awareness raising activities, developing publications and conducting seminars and international exchanges. International networking intensified as a result of the increasing popularity of seed festivals, as well as the recognition of Panagiotis Sainatoudis among the 'Guardians of Diversity in the Mediterranean' by Bioversity International in 2009. . Since 2012, Peliti has also created a community seed bank, in an old school provided by a local municipality. The community considers the seed bank to serve as a safety net but not replace conservation and the use of agricultural varieties on-farm, which it actively supports. It is also increasingly involved in struggles for the legal recognition of farmers' rights at the national and EU level. While the non-monetary exchange of goods and services is an important ideological basis of the community, it strongly supports farmers' right to save, use, exchange and sell farm-saved seed if they so wish.

The community operates on the basis of donations, the income from the sale of publications, and volunteer work. Members are ideologically opposed to selling seed and reject even the idea of providing seed in exchange for annual subscriptions - a solution which could potentially bypass the prohibition of sale of seeds of varieties not included in the national and the European catalogues. The community distributes solely traditional seeds in the public domain free of charge. This saves them a host of legal challenges, but adds to financial ones. The limited finances pose obvious obstacles to its activities, for instance, regarding the operations of the seed bank. However, the range of its activities appears to be disproportionately large with regard to its finances, with 50,000 seed pockets distributed yearly by post, several dozens of thousands distributed in planned events and seeds sent to countries in crisis, including Palestine and Syria.

Ironically, the Greek financial crisis had an asymmetrical effect on the community; while its finances plummeted and continuation of the work relied almost exclusively to donations from like-minded organizations and individuals abroad, its seed-sharing activities started attracting an ever-increasing degree of attention. This is arguably linked to the rise of bottom-up initiatives, which provided solutions based on solidarity economy at times of crisis in the country. Such diverse initiatives, embodying different political tendencies and operating in different ways, include food and agricultural cooperatives, 'no intermediaries' markets, communal and municipal gardens promoting food self-sufficiency, ecocommunities covering also access to land and natural resources and communitysupported agriculture schemes supporting networks of consumers and producers (Backes et al. 2018). Peliti can be situated within this wave of mostly selforganized responses to crisis, further collaborating with many of these initiatives providing seed. This wave also points to the emergence of a food sovereignty movement in the country, at times when austerity measures generally increased rural poverty particularly for smallholders. 
According to community member Vasso Kanellopoulou, the distribution and thus utilization and development of genetic resources is among the community's biggest accomplishments. The community has a strong belief in farmer-based innovation, and highlights that recognition of such innovation is lacking in Greece. This is reflected in farmers denied access to genetic resources stored in the national genebank and lack of legal support for traditional varieties. Participation in law and policymaking processes at the national and European level is also becoming increasingly important, aiming at the increased recognition of farmers as innovators and farmers' rights, including the seed-related rights explored in detail in the second chapter.

At the latest general assembly in 2019, the community decided to decentralize administration of local groups and transform itself into a network, maintaining regular collaboration and communication activities. Following intense discussions, local groups became independent with a focus on seedsaving and distribution, while the original Peliti non-profit organization, still coordinated by Panagiotis Sainatoudis together with an administrative board, would focus on networking with international groups and creation of an eco-community.

\section{The Potato Park}

The Potato Park is an indigenous biocultural heritage area in the Peruvian Andes. ${ }^{8}$ It is one of the few successful examples of a self-organized and selfmanaged indigenous territory, promoting a rights-based approach to biodiversity conservation and agricultural production in general. Built on a unique governance system combining customary laws with concepts inspired from international environmental law, it has attracted the attention of practitioners and academics, as well as international organizations, leading to a significant body of academic commentary and grey literature.

The park covers an area spanning 8240 hectares of communal land in Pisaq, the Sacred Valley of the Incas, between 3400 and 4500 metres above sea level in the Peruvian Andes. It currently incorporates the communal land of six Quechua communities, the Amaru, Chawaytire, Cuyo Grande, Pampallaqta, Paru Paru and Sacaca, with approximately 6000 residents (Argumedo 2012). The initiative was established in 1998, on the basis of communities' wish to preserve their knowledge and agricultural biodiversity particularly regarding native potato varieties, while securing their right to self-determination (Montenegro de Wit 2011). In developing the agreements that set up the Potato Park governance structures, the communities were supported by a Peruvian non-profit association (Asociación ANDES), and an international non-governmental organization (the UK-based International Institute for Environment and Development - IIED).

The agreements that form the basis of the Potato Park operate from the territorial to the genetic level (Montenegro de Wit 2011) and address a range of relations and arenas, from the establishment of the community as an autonomous legal entity and its institutional relation with the regional government and the 
Peruvian state to its relation with outsiders who want to use the Park's resources, as well as intra-community relations.

At the territorial level, the Park communities worked together to devise a communal land-sharing arrangement based on the indigenous ayllu concept, overcoming previous territorial disputes over contested boundaries between their lands (Nabhan 2008). A holistic territorial approach still thriving in the Andes, the ayllu is formed by three interconnected and interdependent communities, creating the conditions for ecological sustainability: humans and domesticated species; wild and semi-domesticated species; and the sacred and the ancestors. The main objective of ayllu is the attainment of wellbeing or Sumaq Causay. The overall objective of self-determined development, Sumaq Causay refers to the positive relationship between humans and their social and natural environments, which is achieved through maintaining reciprocity, duality and equilibrium, the three key customary Quechua principles, explored below as basis for the development of the inter-community agreement on benefit-sharing (ANDES, Potato Park Communities and IIED 2012; Tapia and Tobin 2013). This revitalization of traditional Andean systems promotes a reciprocal relationship between people and their environment in the Park.

Agricultural activities in the area are considered to fall under the concept of common-field agriculture (Godoy 1991). In great similarity with traditional land use in Ikaria as explored in the second chapter, private land in the Cusco valley was scattered among common fields; villagers had grazing rights in common fields after harvesting and during the years they were fallow; they also had the right to gather timber and firewood from the common fields, and they regulated and supervised land use collectively (Godoy 1991). These practices, based on subsistence activities and diversified land use, have been crucial in developing and maintaining a high degree of agricultural biodiversity.

Sustainable management of the Park's agricultural biodiversity within a selfdetermined land-use and governance system is the focus of the initiative. The Potato Park is located at the centre of origin of the potato; the region is home to approximately 2300 of the 4000 known potato varieties in the world, while the genetic diversity found within one plot of land in the area can reach up to 150 varieties. The potato has been cultivated by Andean farmers for over 7000 years, and the area of the Park serves as a genetic reserve, with 700 local cultivars, including 410 varieties repatriated from the International Potato Centre (CIP), one of the international agricultural research centres of the CGIAR Consortium (Argumedo 2012). Traditional farming also includes: the cultivation of other native Andean crops, such as olluco, beans, maize, quinoa, wheat, tarwi, mashua and oca (Loong Wong and Argumedo 2011); the raising of domesticated animals such as guinea pigs and llamas; the use of wild species for food and medicinal purposes; and practices including community labour, the use of traditional tools, complementary plantings and ritual offerings to Mother Earth (Argumedo 2008).

By transforming these traditions into a customary legal framework as the basis for territorial arrangements at the intra-community level, the indigenous peoples living in the Park asserted their biocultural diversity as the legal basis 
for self-determination (Montenegro de Wit 2011). At the same time, the Park's representation towards the Peruvian state needs to be within the boundaries of Peruvian laws, to ensure formal legitimacy. Establishment of the Potato Park was made possible because Peru's legal framework created enough openings to allow such expression of self-determination. In line with ILO Convention no. 169 , the Constitution guarantees the right to land, whether private or communal (Art. 88), and recognizes that peasant and native communities are legal entities, autonomous in their organization, and have the right to use and dispose freely of their lands (Art. 89). In 1974, the Law of Native Communities and Agrarian Regional Promotion in the Lowlands Forests and Valleys (Decree 20653) was the first piece of legislation to explicitly recognize indigenous groups as entitled to legal protection and recognition, as well as to collective land rights. Since then, Peru has formalized property rights for 1200 indigenous communities. In 1978 , to comply with a series of reforms, a new law for titling native communities (Decree 22175) was approved. This law added land-use classification to the procedures required to title native communities; communal rights would only be granted to agricultural or pasture lands, while for land classified as forest, indigenous communities could only claim usufruct rights (Monterroso et al. 2017). The complexities of the system represent another illustration of the challenges associated with land governance; they are, however, beyond the scope of this case study. Under this territorial system, the Potato Park communities have formal legal recognition and communal land titles. Recognition of the Potato Park as a protected area within Peru's National System of Protected Areas, however, has not been achieved, despite repeated efforts (Argumedo 2008).

In accordance with Peruvian legislation (Law of Peasant Communities no. 24656/1987), the communities have organized themselves under the umbrella of the 'Association of the Communities of the Potato Park', with common goals including the conservation of agricultural biodiversity, the development of indigenous territoriality based on solidarity economy and innovations associated with genetic resources and traditional knowledge and the promotion of traditional resource rights. Governance of the Association, in accordance with the law's requirements, is based on a general assembly, made up of the authorities of each of the six communities, a community board and specialized activity committees. This formal governance and representation system co-exists with traditional governance structures, corresponding to three levels of administration at the landscape, the community and the family scale (ANDES, Potato Park Communities and IIED 2012).

In this context, the Potato Park communities had the necessary legal space to develop a territorial development strategy autonomously, establishing economic initiatives based on the interlinkages between biological and cultural diversity and creating novel local products and services based on their traditional knowledge and natural resources and genetic diversity. Establishing an alternative, inclusive development model in support of cultural identity and biocultural heritage was one of the objectives of the Potato Park. Based on reciprocity and 
solidarity, a series of economic collectives were established in the Park, aiming at conserving and using sustainably biological resources. These included collectives on seed repatriation and conservation, crafts, gastronomy, agroecotourism and medicinal plants, as well as a women's video collective, in which women are trained in making and digitally editing videos in the local language, to record and share knowledge about the management of local resources. Finally, a women's collective on medicinal plants addressed specifically marginalization of indigenous women through education and training, while promoting the use and transmission of indigenous knowledge associated with the conservation and sustainable use of local medicinal plants, including development of natural products (ANDES, Potato Park Communities and IIED 2012).

Passing from the landscape to the seed level, it was the signing of the repatriation agreement with CIP in 2004 that provided the impetus for developing the inter-community agreement on benefit-sharing that lies at the heart of the Potato Park. CIP has been collecting potato varieties from the area since the 1960s. Following deliberations, in view of indigenous stewardship of genetic resources of a key food crop, customary laws on reciprocity and changes in international law with regard to plant genetic resources, an agreement for the 'Repatriation, Restoration and Monitoring of Native Potato Agrobiodiversity and Associated Knowledge of Indigenous Communities" ${ }^{\prime 2}$ was signed (ANDES 2010). The agreement provides for the repatriation of seeds and commitments for sharing of benefits derived from their use, as well as from the use of associated traditional knowledge. It recognizes that the ITPGRFA provisions are fundamental for its effective implementation, further noting that the Potato Park 'forms an innovative bridge between traditional concepts of in situ and ex situ conservation'.

The objectives of the repatriation agreement include ensuring that genetic resources and knowledge remain under the custody of the communities and do not become subject to any form of IPRs, and promoting, through collaborative research, the role of in situ and ex situ strategies for the conservation of agricultural biodiversity. As part of their joint responsibilities, the parties agreed to support the Potato Park communities' right to benefit-sharing and to promote collaborative research and development activities, including the recording and protection of relevant community knowledge systems, as well as to implement the agreement in accordance with the principle of open sharing for mutual benefit and for the benefit of the humanity. The Park is further responsible for maintaining access to the genetic material, including providing it for distribution and sowing by members of the Potato Park and third parties. CIP was required to prepare and make available the genetic material for its repatriation, guarantee that it is free of pests and diseases and provide technical assistance to the Park for its maintenance, monitoring, multiplication and management. CIP thus took over the cost of repatriation. The parties further recognized the role of the Potato Park in developing a community protocol, as explored below.

The repatriation agreement was of crucial importance for the Potato Park experiment. First, it marked the Park's existence as an autonomous entity, to be respected under Peruvian law, and with the capacity to sign an agreement with a 
CGIAR centre - an act which acquires relevance also for international environmental law. The agreement highlighted the beginning of a consistent engagement of the Park in international deliberations on plant genetic resources, as explored below. Second, the agreement with CIP served as a registry of local varieties and legal protection against the claiming of IPRs on them. Finally, it was a driver of the participatory process among the Potato Park communities, which led to the development of the inter-community agreement on fair and equitable benefitsharing (ANDES, Potato Park Communities and IIED 2012); a mechanism was needed to ensure the equitable sharing of the repatriated seeds and of monetary benefits derived from this agreement, as well as of revenues derived from other economic activities in the park, to avoid potential conflicts among the communities.

The inter-community agreement on benefit-sharing, established among the six communities that manage the Park, holds a central position in its structure and governance system. Developed following a three-year-long participatory process, it is rooted in conservation and equity values enshrined in customary laws, and is regulated by the community and inter-community authorities. The governance structures aim to minimize the risk of conflicts over resources and of elites unfairly benefiting from revenues, while a percentage of the revenues is reinvested into a communal fund which is used to sustain and manage the Park's agro-ecosystem and provides a safety net for the poorest people in the Park communities (Swiderska et al. 2006). At the same time, the agreement serves as a biocultural community protocol for outsiders, for access to genetic resources and benefit-sharing in the sense of the Nagoya Protocol on ABS, mentioned in previous chapters. In the following paragraphs, based on records published by project participants, I am exploring in further detail the participatory process that led to the agreement, as a rare bottom-up example of benefit-sharing that speaks both to the international and the local level, as well as the agreement itself.

The process that led to the agreement was a complex one, illustrative of the challenges that accompany an endogenous benefit-sharing exercise. Challenges involved: designing a culturally sensitive participatory process combining Western and indigenous tools; articulating the results in a specific way to respond to communities' needs while contributing to environmental sustainability; and linking the oral Andean traditions with written instruments (ANDES, Potato Park Communities and IIED 2012; Swiderska et al. 2009). Guided by ANDES, IIED and indigenous researchers of the Park, participants started from identifying the customary norms that guide Andean practices of reciprocity and allow for redistribution of wealth among communities, as well as any potential new mechanisms that would be required to adapt these norms to current realities, before getting into several rounds of consultations on the actual rules and mechanisms of the agreement, in order to develop equitable models for access and benefit-sharing.

Alejandro Argumedo (2012) analyses in detail the methodological challenges encountered and process followed, so that development of the agreement contributes to the empowerment of the communities involved and their institutions, 
enabling effective control of decision-making. The selected methodology was designed and implemented collaboratively with indigenous community partners, and involved use of indigenous methods such as myths and drawings, combined with Western participatory methods, regarding engagement of all relevant stakeholders. Focus was put on emancipatory/decolonization approaches to access and benefit-sharing, based on critiques of colonial relations in past research involving indigenous peoples. Quechua ways of learning were integrated as a way of resisting dominant discourses and addressing explicitly issues of power and rights. Indigenous researchers acted as a bridge between Western and indigenous knowledge systems and methods, and capacity-building for all involved was an important part of the process.

The process included three phases: identification of relevant community norms and customary laws; consultation, drafting and revision of the inter-community agreement; and final decision-making and validation of the agreement. The three key Andean principles of reciprocity, duality and equilibrium considered to underpin all natural resource management practices were used as a basis, in addition to other customary rules and practices, including on community-level conflict resolution. The principle of reciprocity, which includes the principles of equity and fairness and provides the basis for exchange between people and nature, is based on complementarity and redistribution, as opposed to competition and accumulation inherent to capitalist systems. It is applied, for instance, to the exchanges of seeds and knowledge. The principle of duality is reflected in the division of labour between men and women with mutual interdependence, as translated, for instance, in the transmission of knowledge related to agricultural practices, or the balance between rights and obligations, both of which should be met to achieve harmony. Finally, the principle of equilibrium refers to harmony between community members, and to respect for nature and the sacred world. It is applied to decision-making and conflict resolution, as well as the fair and equitable distribution of profits in relation to needs, capabilities, responsibilities, contributions and efforts (ANDES, Potato Park Communities and IIED 2012).

The consultation, negotiation and drafting process aimed to identify the common interests of the communities, the objectives and the scope of the agreement. Community participation thus needed to be expanded to ensure control of the process for development of the agreement. A broad consultation was initiated throughout the Park, involving community members and local authorities in 30 consultation groups. These groups met several times to discuss different aspects of the draft agreement, while additional feedback was acquired through semi-structured interviews. Traditional practices were used to maintain flows of dialogue; as an illustration, the gastronomy collective served traditional potato dishes to consultation groups, both as an expression of reciprocity and to facilitate discussion about biocultural heritage.

Differences related to varying degrees of use of biocultural heritage and links with markets, expectations regarding the benefits to arise from the Potato Park, as well as the decision-making authority communities were willing to delegate to the Association. Discussion regarding distribution of the benefits accrued and 


\section{Exploring grassroots initiatives}

funds generated by activities in the Park resulted in development of criteria reflecting different levels of participation and contribution and what constitutes fair and equitable distribution. At the final stage, community participation was expanded further to identify gaps in the draft, before its review by a group of experts and continued work by study groups for simplification and conceptualization in Quechua terms. Following traditional decision-making procedures, the final draft was presented and discussed in community assemblies, and put to a vote. All Potato Park communities approved the agreement by a large majority (Argumedo 2012).

The Potato Park inter-community agreement for benefit-sharing provides a framework for the sharing of the benefits received by the Potato Park, derived directly or indirectly from its biocultural resources, with its communities and residents. It also serves as a biocultural community protocol in the sense of the Nagoya Protocol, with regard to the relation of the Potato Park as a collective entity with outsiders seeking access to its genetic resources and traditional knowledge. The agreement thus deals with two facets of benefit-sharing: the internal aspect, rarely discussed in academic and grey literature, whereas a community (or as in the case of the Potato Park a collective of communities) seeks to redistribute fairly and equitably among itself the benefits derived from its resources; and the external aspect, which is usually discussed in international environmental law scholarship with regard to both its inter-state and its intrastate dimensions, as explained in the introduction. In the context of this external aspect of benefit-sharing, the community as a provider of genetic resources and traditional knowledge seeks to agree on terms for providing access to its resources to outsiders, in exchange for part of the benefits arising from access to its resources. As noted above, it is also unique in that it links an endogenous development process and rules based on customary norms with elements derived from international environmental law, promoting thus the recognition both of customary law as a source of legitimacy and justice, and of indigenous peoples and peasant communities as subjects of sovereignty in different degrees under international environmental law. Furthermore, the process for its development has inherent value for contributing to the autonomous construction of an indigenous governance model among the Park communities, identifying principles and resolving conflicts as needed.

When it comes to relations with outside users requesting access to the Park's resources and traditional knowledge, the agreement provides that traditional knowledge is collectively owned, and access to it requires the prior and informed consent of the six communities. The Park's general assembly makes all decisions regarding access to the Park's resources and expected terms for benefit-sharing.

In accordance with community traditions, supported also by the Nagoya Protocol provisions (Art. 12(4)), community resources and knowledge are freely accessible to all members of all communities in the Park; everyone has the right to access knowledge and resources and use them in accordance with customary practices, and everyone has the obligation to maintain this flow by transmitting 
knowledge. Benefits that are to be distributed within and between the Potato Park communities and their members may derive from agreements for thirdparty use of the Park's genetic resources and traditional knowledge, repatriation of seeds, including, for example, under the agreement with CIP, activities undertaken by the Park's collectives and projects or donations.

The Potato Park Association has functions related to implementation of the agreement, including allocation of benefits between the Park communities and regulation of the Park's collectives. Each community has three types of beneficiaries: those directly involved in Park's activities; indirect beneficiaries, who are involved in conservation and maintenance activities or belong to the communities who benefit from redistribution of the Park's funds; and potential ones, including, for instance, future generations. Each community determines the terms for sharing of benefits among the different types of beneficiaries. Distribution of benefits is operated by a specific committee created by the Association, the Benefits Allocation and Oversight Committee, as well as the Papa Arariwa, the Potato Collective, which was created specifically to address the distribution of repatriated potato seeds. The criteria for distribution of monetary and non-monetary benefits provide that such distribution should be fair and proportionate to the needs, capabilities, responsibilities, contributions and efforts of the communities and their members. A percentage is used to develop and maintain a social safety net on the basis of solidarity; in addition, the Inter-Community Fund for Benefit-Sharing receives $10 \%$ of the collectives' earnings, as well as contributions from Park admission fees associated with tourism and educational activities. These funds are redistributed among the Park's communities, as a contribution towards the maintenance of the collective biocultural heritage and on the basis of principles of solidarity (ANDES, Potato Park Communities and IIED 2012). The agreement further provides for a conflict resolution mechanism at three levels: the family, traditional authority and the community's general assembly. When conflicts involve more than one community, they are resolved by the Park's general assembly. The system has a restorative focus, so decisions aim at restoring social balance.

The case of the Potato Park is illustrative of the possibility for autonomous community-based land and resource management, in light of constructive interactions between customary, national and international law. Established on the basis of customary law, the Potato Park has taken advantage of openings in national and international law to strengthen and support its structures and governance system, showcasing the importance of legal empowerment. Engagement of Potato Park representatives with decision-making processes from the local to the international level has increased awareness of available rights and opportunities, and has promoted mutual recognition as a result. Involvement of the Potato Park at international-level processes of relevance to plant genetic resources and traditional knowledge is particularly impressive. In addition to the repatriation agreement with CIP, which was renewed in 2010, the Potato Park has been among the beneficiaries of funding from the ITPGRFA Benefit-sharing Fund. Notably, the Potato Park communities do not only receive benefits from, but also contribute to international mechanisms; they are one of the very few 
non-state entities to have voluntarily placed their potato collections in the ITPGRFA Multilateral System (ITPGRFA Secretariat 2013), and they have sent duplicates of all samples to the Svalbard Global Seed Vault, a backup storage facility of seed samples, to secure availability of their varieties for future generations (Kinver 2011; Tapia and Tobin 2013). In addition, the participatory process that led to the inter-community agreement enabled the development of governance structures, empowering the community to build its own vision of development and thus decision-making ability, in order to inform about and negotiate with outside users the terms for access to its genetic resources and knowledge and benefit-sharing under the provisions of the Nagoya Protocol.

\section{Discussion: identifying trends and questions}

The account of these case studies illustrates the creation of new, value-based communities involved in the conservation and sustainable use of agricultural biodiversity. Operating within a wide range of circumstances and contexts, they are indicative of the variety of approaches used to re-imagine creatively their legal environment and specific legal tools or to circumvent legal obstacles and continue sharing benefits and resources. A full analysis is beyond the scope of this endeavour, which serves mostly to outline areas for future research. Some trends can be discerned, however, to serve as guidance.

The first remark concerns the need for recognition and promotion of farmerbased innovation. All of these initiatives aim at empowering the farmer and affirm her capacities for innovation on-farm, against the full professionalization of breeding and the corporate control of agricultural development. Participatory plant breeding projects have used farmer field schools as a suitable instrument for empowering farmers and giving recognition to their knowledge. The Open Source Seed Initiative aimed to integrate the skills and capacities of farmer breeders with those of plant scientists and encourage and reward the sharing rather than the restriction of germplasm. The Peliti community distributed traditional seeds for free to amateur gardeners and urban gardens, as part of a larger movement building a solidarity economy and a food sovereignty network at times of financial crisis in Greece, declaring at the same time that recognition of farmer-based innovation is among its main objectives. At the uniquely successful case of the Potato Park, indigenous farmers managed potato diversity in an illustration of the potential of autonomous community-based land and resource management. While many fora recognize farmer-based innovation and seed systems as a structural component of agricultural development and sustainable food systems, the mainstream paradigm still excludes them, resulting in lack of institutional and legal support.

Second, the legal context is of vital importance and is also linked to concerns regarding financial sustainability. Participatory plant breeding programmes struggle due to lack of legal support, and need to address challenges regarding legitimate access to source material and legal recognition and protection of the outcomes of collaborative processes. The Peliti community bypasses legal 
obstacles to farmers' rights by distributing seed for free; however, it prioritizes its efforts to change the national legal framework for recognition of farmers' rights to seed and farmers as innovators. The open-source experiment was born out of the desire to ensure a legally safe space for continued innovation within a hostile legal framework defined by patents, and still struggles between copyleft licenses and ethical commitments through pledges.

On the other hand, an enabling legal framework was key to the success of the Potato Park, the communities and representatives of which used openings in national and international law to organize and strengthen customary structures and governance systems. Establishment of the Potato Park was possible because Peru's legal framework created the necessary legal space to allow such expression of self-determination; the Potato Park communities have formal legal recognition and communal land titles. In addition, international recognition and support provided the impetus for the development of an autonomous territorial development strategy, including biocultural conservation and economic initiatives on the basis of the biodiversity, natural resources, traditional knowledge and customary values. The repatriation agreement with CIP was the driver of the participatory process that led to the development of the inter-community agreement on fair and equitable benefit-sharing. As such, the Potato Park is a rare example of constructive interactions between customary, national and international law.

Third, the question of underlying values should be finally acknowledged and discussed. All of these initiatives, each to varying degrees, involve a collective endeavour to achieve a common goal and social benefits beyond strictly material, individual or even collective gain. Participatory plant breeding projects do not aim at simply producing improved agronomic outputs for marginalized farmers, even though that would be a noble objective in itself; they also address objectives related to environmental sustainability, empowerment and improved livelihoods. The Peliti community bypasses all considerations regarding remuneration and monetary exchanges as a matter of principle, inspired by the seed and working for conservation, similar to many collectives around the globe, to which community members feel connected through their common objectives. Participants in opensource initiatives are united in the resistance against IPR-related restrictions on innovation and their faith to the efficiency of the sharing of knowledge to address global challenges. That said, participants in the Open Source Seed Initiative had principled diverging opinions on the use of licenses and genetic engineering (Kloppenburg 2014), indicating the wealth of political and moral issues relevant for agricultural production on top of IPRs that need to be addressed and resolved in a specific societal context. The Potato Park communities finally managed to build an endogenous development model adapting Andean traditions and customary norms on reciprocity, duality, equilibrium and solidarity to their current circumstances to develop a model benefit-sharing agreement. Choices related to agricultural research, development and production are politically and culturally charged. A community may take a different path to another, and this largely depends on its political predispositions and socio-cultural context. 
The question of underlying values brings us to the fourth issue. Community organization and building is key for the creation and sustainability of bottom-up benefit-sharing mechanisms. As the case studies illustrate, communities involved in conservation of biodiversity and agricultural innovation vary greatly in participation, are rarely homogeneous and can be either local or virtual and globalized. In addition, communities should not be taken for granted. The lengthy and complex participatory process that led to the development of the Potato Park benefit-sharing agreement is a testament to that fact, despite participants all being members of neighbouring, culturally close communities. Designing and conducting a culturally sensitive participatory process combining Western and indigenous tools, in light of centuries of colonial history and disempowerment of indigenous peoples is no easy process. Addressing participation-related issues is more challenging in less homogeneous groups. Participatory plant breeding projects, for instance, encountered a host of issues related to inclusiveness, choice of participants, addressing gender issues, defining the desired outcomes and building a common language to accommodate the knowledge and experiences of all participants, farmers and conventional plant breeders alike. Inspiration, however, can come from unlikely sources; in the current highly interconnected world, an indigenous peasant community can find links with an anti-capitalist urban movement and vice versa. The most popular distribution under the Linux open-source software is called Ubuntu, named after the African Nguni philosophy of ubuntu to reflect the belief in a universal bond of sharing that connects all humanity. ${ }^{10}$

Considerable time, effort and good faith is necessary to allow for recognition and empowerment of participants and enable control of the decision-making process, particularly if they come from different backgrounds, and this is a lesson also for international processes of relevance to benefit-sharing. In addition, structures facilitating participation, such as collectives and cooperatives, are a valuable tool for empowerment. The high level of farmers' organization in communes and their familiarity with farmer field schools were important factors contributing to the success of participatory plant breeding programmes in Vietnam, and preexisting traditional community authorities served as the basis for building the Potato Park Association. The Potato Park experiment can provide a wealth of lessons to international processes, from the effort and organization put into the participatory process for setting up the agreement, which has also empowered the community to negotiate with outsiders seeking access to its genetic resources and traditional knowledge, to the actual design of the agreement, leading to a sophisticated scheme for intra-community distribution of benefits in relation to needs, capabilities, responsibilities, contributions and efforts.

Communities are certainly dynamic, built around values but also around specific resources or needs. It can be argued that a novel community based on new collaborations requires a longer experimentation stage in order to, first, build trust among its members and, second, develop its own cooperative management strategies. Particularly when it seeks to address complex, globally important problems such as biodiversity conservation and food security, linked to long 
histories of colonial and neocolonial domination (Aoki 1998), it is important to address equity- and redistribution-related concerns (Hess and Ostrom 2007), including through building the differentiated capacities of its members. Such governance approaches may delay operation and might impact efficiency; they may, however, be instrumental for the long-term sustainability of the project and the community itself. Further research would help identify the critical factors that lead to success, including a governance system that leads to sustainability and, as Charles Schweik puts it, those pre-conditions that 'somehow establish a situation where participants and/or organizations are willing to devote time, energy, and resources to building these commons' (Schweik 2007: 303).

\section{Notes}

1 FAO Voluntary Guide for National Seed Policy Formulation, endorsed by the Commission on Genetic Resources for Food and Agriculture in 2015.

2 The Toolbox for Sustainable Use for PGRFA is available at: www.fao.org/planttreaty/tools/toolbox-for-sustainable-use/sustaining-local-crop-diversity/en/ (last accessed 26.1.2020).

3 Information available at: www.sdhsprogram.org/ (last accessed 26.1.2020).

4 This case study is based on reworked and updated abstracts from: Tsioumani, E., Muzurakis, M., Ieropoulos, Y. and Tsioumanis, A. (2016) 'Following the Open Source Trail outside the Digital World: Open Source Applications in Agricultural Research and Development', TripleC: Communication, Capitalism and Critique, 14(1): 145-162.

5 OSSI Pledge, available at: https://osseeds.org/the-open-source-seed-initiative-growingaccess-to-a-liberated-domain-of-plant-genetic-diversity/ (last accessed 20.1.2020).

6 This case study is based on an interview with Peliti's member Vasso Kanellopoulou, to whom I am deeply grateful, and a review of the information offered on Peliti's website, available at: https://peliti.gr/ (last accessed 20.1.2020).

7 Bioversity International (2009) Geneflow 2009, available at: www.bioversityinter national.org/e-library/publications/detail/geneflow-2009/ (last accessed 20.1.2020).

8 This case study is based on a literature review and several conversations I've had over the years with Alejandro Argumedo, co-founder of ANDES Association, to whom I am deeply grateful.

9 The agreement is available at: www.grain.org/fr/entries/2165 (last accessed 28.1.2020).

10 I am grateful to Mike Muzurakis for this observation.

\section{References}

African Centre for Biodiversity (2018) A Review of Participatory Plant Breeding and Lessons for African Seed and Food Sovereignty Movements. Johannesburg: African Centre for Biodiversity.

Almekinders, C. and Hardon, J. (eds) (2006) Bringing Farmers Back into Breeding: Experiences with Participatory Plant Breeding and Challenges for Institutionalisation, Agromisa Special 5. Wageningen: Agromisa.

ANDES (2010) 'Communities of the Potato Park Sign a New Repatriation Agreement with the International Potato Centre', ANDES press release, available at: www.andes. org.pe/note-communities-of-the-potato-park-sign-a-new-repatriation-agreement-withthe-international-potato-cente (last accessed 20.1.2020). 
ANDES, Potato Park Communities and IIED (2012) 'Community Biocultural Protocols: Building Mechanisms for Access and Benefit Sharing among the Communities of the Potato Park based on Quechua Customary Norms', available at: http://pubs.iied.org/ pdfs/G03340.pdf (last accessed 20.1.2020).

Aoki, K. (1998) 'Neocolonialism, Anticommons Property, and Biopiracy in the (Not-soBrave) New World Order of International Intellectual Property Protection', Indiana Journal of Global Legal Studies, 6(1): 11-58.

Aoki, K. (2009) “"Free Seeds, not Free Beer”: Participatory Plant Breeding, Open Source Seeds, and Acknowledging User Innovation in Agriculture', Fordham Law Review, 77(5): 2275-2310.

Argumedo, A. (2008) 'The Potato Park, Peru: Conserving Agrobiodiversity in an Andean Indigenous Biocultural Heritage Area', in T. Amend, J. Brown, A. Kothari, A. Phillips and S. Stolton (eds), Protected Landscapes and Agrobiodiversity Values. Gland: IUCN.

Argumedo, A. (2012) 'Decolonising Action-Research: The Potato Park Biocultural Protocol for Benefit-Sharing', in K. Swiderska with A. Milligan, K. Kohli, H. Jonas, H. Shrumm, W. Hiemstra and M. J. Oliva (eds), Participatory Learning and Action no. 65: Biodiversity and Culture: Exploring Community Protocols, Rights and Consent, available at: www.iied.org/pla-65-biodiversity-culture-exploring-community-protocolsrights-consent (last accessed 20.1.2020).

Backes, S., Gkiougki, J., Kay, S., Konstantinidis, Ch., Mattheisen, E., Sakali, Ch., Tzekou, Ei., Vatikiotis, L. and Vervest, P. (2018) Democracy Not For Sale: The Struggle for Food Sovereignty in the Age of Austerity in Greece. Amsterdam; Heidelberg; Athens; Thessaloniki: Transnational Institute, FIAN International and Agroecopolis.

Benkler, Y. (1999) 'Free as the Air to Common Use: First Amendment Constraints on Enclosure of the Public Domain', NYU Law Review, 74: 354-446.

Black Duck Software (2015) 'Top 20 Open Source Licenses', available at www.immagic. com/eLibrary/ARCHIVES/GENERAL/BLCKD_US/B141112S.pdf (last accessed 20.1. 2020).

Boldrin, M. and Levine, D. K. (2005) Against Intellectual Monopoly, available at: www. dklevine.com/general/intellectual/against.htm (last accessed 20.1.2020).

Boyle, J. (2003) 'The Second Enclosure Movement and the Construction of the Public Domain', Law and Contemporary Problems, 66: 33-74.

De Jonge, B., Manicad, G., Mushita, A., Ignacio, N. G., Argumedo, A. and Visser, B. (2019) 'Seed Laws: Bottlenecks and Opportunities for Participatory Plant Breeding', in O. T. Westengen and T. Winge (eds), Farmers and Plant Breeding: Current Approaches and Perspectives. Abingdon: Routledge/Bioversity International.

Godoy, R. (1991) 'The Evolution of Common-Field Agriculture in the Andes: A Hypothesis', Comparative Studies in Society and History, 33(2): 395-414.

Hamilton, L. (2014) 'Linux for Lettuce', Virginia Quarterly Review, 90(3), available at: www.vqronline.org/reporting-articles/2014/05/linux-lettuce (last accessed 20.1.2020).

Heller, M. (1998) 'The Tragedy of the Anticommons: Property in the Transition from Marx to Markets', Harvard Law Review, 111(3): 621-688.

Heller, M. and Eisenberg, R. (1998) 'Can Patents Deter Innovation? The Anticommons in Biomedical Research’, Science, 280(5364): 698-701.

Hess, C. and Ostrom, E. (2007) 'Introduction: An Overview of the Knowledge Commons', in C. Hess and E. Ostrom (eds), Understanding Knowledge as a Commons: From Theory to Practice. Cambridge, MA: MIT Press. 
ITPGRFA Secretariat (2013) Report on the First Round of the Project Cycle of the Benefit-sharing Fund. Rome: FAO.

Jefferson, R. (2006) 'Science as Social Enterprise. The CAMBIA BiOS Initiative', Innovations: Technology/Governance/Globalization, 1: 13-44.

Kinver, M. (2011) 'Svalbard Seed Vault to Take Peruvian Potato Samples', BBC News, available at: www.bbc.co.uk/news/science-environment-12493970 (last accessed 20.1.2020).

Kloppenburg, J. (2014) 'Re-Purposing the Master's Tools: The Open Source Seed Initiative and the Struggle for Seed Sovereignty', The Journal of Peasant Studies, 41(6): $1225-1246$.

Kotschi, J. and Horneburg, B. (2018) 'The Open Source Seed Licence: A Novel Approach to Safeguarding Access to Plant Germplasm', PLoS Biology 16(10): e3000023.

Loong Wong, B. Y. and Argumedo, A. (2011) 'The Thriving Biodiversity of Peru's Potato Park', United Nations University Our World, available at: https://ourworld.unu. edu/en/the-thriving-biodiversity-of-peru-potato-park (last accessed 28.1.2020).

Louafi, S. and Welch, E. (2014) 'Open Systems versus Strong Intellectual Property Rights: Disentangling the Debate on Open Access for Meeting Global Challenges in Life Science', in J. Y. Grosclaude, L. Tubiana and R. K. Pachauri (eds), A Planet for Life 2014: Innovation for Sustainable Development. New Delhi: Teri Press.

Manzella, D. and Louafi, S. (2019) 'Participatory Plant Breeding and Sui Generis Plant Variety Protection', in O. T. Westengen and T. Winge (eds), Farmers and Plant Breeding: Current Approaches and Perspectives. Abingdon: Routledge/Bioversity International.

Montenegro de Wit, M. (2011) 'The Potato Park: Protecting Biocultural Diversity, Reviving the Incan Ayllu, and Sowing the Seeds of Food Sovereignty in the Highlands of Peru', University of California: Berkeley (on file with the author).

Monterroso, I., Cronkleton, P., Pinedo, D. and Larson, A. M. (2017) 'Reclaiming Collective Rights: Land and Forest Tenure Reforms in Peru (1960-2016)', CIFOR Working Paper 224. Bogor, Indonesia: CIFOR.

Morris, M. L. and Bellon M. R. (2004) 'Participatory Plant Breeding Research: Opportunities and Challenges for the International Crop Improvement System', Euphytica, 136: 21-35.

Nabhan, G. (2008) 'Parque de la Papa: Vavilov's Dream for Potatoes', available at: www.garynabhan.com/news/2008/09/parque-de-la-papa-vavilovs-dream-for-potatoes/ (last accessed 28.1.2020).

Open Source Initiative (2012) 'History of the OSI', available at: http://opensource.org/ history (last accessed 20.1.2020).

Salazar, R., Manicad, G., Dohar, A. and Visser, B. (2019) 'Participatory Plant Breeding: Human Development and Social Reform', in O. T. Westengen and T. Winge (eds), Farmers and Plant Breeding: Current Approaches and Perspectives. Abingdon: Routledge/Bioversity International.

Schweik, C. (2007) 'Free/Open-Source Software as a Framework for Establishing a Commons in Science', in C. Hess and E. Ostrom (eds), Understanding Knowledge as a Commons: From Theory to Practice. Cambridge, MA: MIT Press.

Stallman, R. (1985) 'The GNU Manifesto', available at: www.gnu.org/gnu/manifesto. html (last accessed 20.1.2020).

Stallman, R. (2004) 'The Free Software Community After 20 Years: With Great but Incomplete Success, What Now?', available at: www.gnu.org/philosophy/use-freesoftware.html (last accessed 20.1.2020). 


\section{Exploring grassroots initiatives}

Stallman, R. (2006) 'Did You Say “Intellectual Property"? It's a Seductive Mirage', available at: www.gnu.org/philosophy/not-ipr.en.html (last accessed 20.1.2020).

Swiderska, K., Pant, R., Argumedo, A., Song, Y, Mutta, D., Munyi, P., Herrera, H., Vedavathy, S. and Nellithanam, J. (2006) Protecting Community Rights over Traditional Knowledge: Implications of Customary Laws and Practices (Emerging Case Study Findings and Recommendations), IIED project report, available at: https://pubs. iied.org/14590IIED/ (last accessed 20.1.2020).

Swiderska, K., Argumedo, A., Song, Y, Li, J., Pant, R., Herrera, H., Mutta, D., Munyi, P. and Vedavathy, S. (2009), Protecting Community Rights over Traditional Knowledge: Implications of Customary Laws and Practices. Key Findings and Recommendations 2005-2009, IIED project report, available at: https://pubs.iied.org/14591IIED/ (last accessed 28.1.2020).

Tapia, M. and Tobin, B. (2013) 'Guardians of the Seed: the Role of Andean Farmers', in E. C. Kamau and G. Winter (eds), Common Pools of Genetic Resources: Equity and Innovation in International Biodiversity Law. Abingdon: Routledge.

Toledo, A. (2019) 'Funding Participatory Plant Breeding', in O. T. Westengen and T. Winge (eds), Farmers and Plant Breeding: Current Approaches and Perspectives. Abingdon: Routledge/Bioversity International.

Tsioumani, E., Muzurakis, M., Ieropoulos, Y. and Tsioumanis, A. (2016) 'Following the Open Source Trail outside the Digital World: Open Source Applications in Agricultural Research and Development', tripleC: Communication, Capitalism and Critique, 14(1): $145-162$.

Weber, S. (2004) The Success of Open Source. Cambridge, MA: Harvard University Press.

Westengen, O. T. and Winge, T. (2019) 'New Perspectives on Farmer-Breeder Collaboration in Plant Breeding', in O. T. Westengen and T. Winge (eds), Farmers and Plant Breeding: Current Approaches and Perspectives. Abingdon: Routledge/Bioversity International.

Winge, T. (2019) 'Participatory Plant Breeding as a Tool for Implementing Farmers' Rights and Sustainable Use under the Plant Treaty', in O. T. Westengen and T. Winge (eds), Farmers and Plant Breeding: Current Approaches and Perspectives. Abingdon: Routledge/Bioversity International. 


\section{Conclusions and a research agenda}

\section{Conclusions}

The preceding legal analysis provided useful elements for the conceptualization of fair and equitable benefit-sharing in agriculture, leading to the identification of trends and challenges regarding its application.

Fair and equitable benefit-sharing is a well-established, legally binding policy objective in the field broadly known as 'access and benefit-sharing' (ABS) for biodiversity-based research and development, as explored in the first chapter. It has been established in accordance with the rules of the Convention on Biological Diversity (CBD), which reaffirmed the principle of national sovereignty over natural and genetic resources. Aiming to establish a system for bilateral exchanges of genetic resources between providers and users, and with fair and equitable benefit-sharing featuring prominently among its objectives, the CBD subjects access to the prior informed consent of the country providing such resources, and to mutually agreed terms for benefit-sharing. Linked to the principle of national sovereignty, fair and equitable benefitsharing aimed to ensure that some portion of the benefits arising from the use of their resources flow back to the providers, as a balancing tool against the privatization of genetic resources via intellectual property rights. Benefitsharing can further be conceptualized as a tool for the recognition of the stewards of these resources and their reward, in a context of global cooperation in the pursuit of solidarity and justice, as well as a development and conservation tool, allowing part of the benefits from the emerging biodiversity market to flow to the stewards of biodiversity and providers of the raw material for this market, to improve their livelihoods and enable their continued contribution to biodiversity conservation.

In response to adoption of the CBD as well as the specificities of agricultural biodiversity and the needs of the agricultural community to continue exchanges of genetic material for objectives linked to global food security and sustainable agriculture, the International Treaty on Plant Genetic Resources for Food and Agriculture (ITPGRFA) was adopted. The Treaty has established a highly sophisticated multilateral mechanism to serve the objective of fair and equitable benefit-sharing. Its Multilateral System (MLS) regulates access to a common 
pool of crops and forages considered vital for food security and agricultural research, and monetary and non-monetary benefit-sharing arising from the utilization of these resources. The terms for exchange of material in the MLS are provided in the Standard Material Transfer Agreement (SMTA), a standardized private-law contract between a provider and a recipient (user) of genetic resources, which has been adopted by the Treaty's Governing Body following intergovernmental negotiations. Accumulation of benefits from users of the system towards the common pool of resources is conducted according to the terms of the SMTA, while distribution of benefits back to providers, in this case farmers in developing countries, proceeds through projects financed via the Treaty's Benefit-sharing Fund.

The MLS has been successful in many ways. It has been facilitating hundreds of thousands of exchanges of genetic resources every year, mainly to enable public agricultural research; it has further provided valuable support, particularly through non-monetary benefit-sharing to build the capacities required for facilitated access to, and use of, PGRFA. It is thus instrumental in building endogenously defined needs and capacities of countries and communities, and bridging the fairness and equity gap in agricultural research and development. These successes, however, have been overshadowed by expectations for monetary benefits, in the context of growing inequities due to trade and IPR-related policies, highlighted below.

As a result of challenges that have arisen with regard to the ability of the MLS to generate and share monetary benefits, as analysed in the first chapter, very limited user-based payments have been realized since the Treaty's entry into force. The Benefit-sharing Fund has been operating solely on the basis of donor country voluntary contributions. Consequently, a working group was specifically mandated in 2013 to 'enhance the functioning of the Multilateral System'. However, following six years of deliberations, including an immense amount of work on complex legal and policy issues, time and financial resources spent on the effort and tentative agreement reached on several important matters, including expanding the list of crops in the MLS and devising a system for access to MLS crops mainly upon subscription, negotiations collapsed at the Governing Body session in November 2019. The collapse marked a missed opportunity for the Treaty, sustainable agriculture and multilateralism in general. For the time being, benefit-sharing will continue under the Treaty as originally established.

Despite the shortcomings, I argue that the objective of fair and equitable benefit-sharing introduces both legally binding obligations for parties to the treaties that establish it, and a sharing ethos in international environmental law, with the potential to affect the acceptability and legitimacy of policy action beyond strict legal frameworks.

In the second chapter I explored applications of fair and equitable benefitsharing in the field of land governance, a vital field of law in the struggle for endogenous agricultural development, rarely studied in conjunction with the field of ABS for research and development. In this context, farmers' rights provide a 
preferential field of study, as they are situated at the interface between the regulation of agricultural research and development, and land and human rights. Following a detailed analysis, I propose a broad construction of farmers' right to benefit-sharing, to encompass not only the outcome of benefit-sharing as a process, but also a series of supporting elements and enabling conditions for smallholder farmers, including secure land tenure and access to seeds, as well assistance in the organization of cooperatives and access to markets. Stemming from the ITPGRFA multilateral approach to benefit-sharing, this understanding aims both to reward and enable farmers' contribution to the conservation and sustainable use of agricultural biodiversity and thus to sustainable agriculture and global food security. In line with the conceptualization of fair and equitable benefit-sharing under research and development as outlined above, this twin 'reward-and-enable' approach suggests that farmers should not only be rewarded in monetary terms for their past and present contribution, but should also be supported to continue their practices in the future. Such broad interpretation is further supported by the UN Declaration on the Rights of Peasants, which puts forward a comprehensive approach regarding the rights of rural populations, linking their vulnerabilities, their special relationship to land, water, seeds and natural resources and their contribution to global food security through rights already protected in international law and new - individual and collective - rights.

Unlike the area of biodiversity-based research and development, where fair and equitable benefit-sharing is an established international law concept and policy objective, land governance is still mostly a matter for national law. International law emerged relatively recently, mainly with regard to indigenous peoples' rights and human rights in general, environmental sustainability and transnational investment. Following this exploration, I conclude that fair and equitable benefit-sharing lacks a consistent normative content and legal bearing across all international instruments of relevance to sustainable agriculture. While still linked to notions of justice and solidarity to the vulnerable, benefit-sharing in land governance is sometimes framed as a policy objective and at other times as a safeguard. In addition, its international legal basis is usually to be found in non-binding instruments.

A crucial question concerning implementation of benefit-sharing from land use is its relationship with actual access to the resource; the benefit to be shared is often the land itself or the right to use it. Examination of benefit-sharing is thus inextricably linked to redistribution efforts for land or agrarian reform, in view of chronic inequality in land distribution in many countries, complex interactions between formal tenure systems and customary arrangements around the globe and the fundamental question of who has decision-making authority, and thus control over land allocation and use.

In this context, the Voluntary Guidelines on the Responsible Governance of Tenure of Land, Fisheries and Forests in the Context of National Food Security (VGGT) establish a clear (albeit broadly worded) policy objective related to benefit-sharing from public lands, and include detailed provisions on redistributive land or agrarian reforms, which can be considered a tool for 
benefit-sharing, aiming to share not only the benefits arising from the resource but also the resource itself. Systems of concessions thus may be used as benefitsharing tools, to promote fair and equitable use of uncontested public land by individuals or farmer cooperatives for food security and rural livelihoods objectives. When it comes to contested use of public land, including in the case of large-scale agricultural investments and/or arbitrary or unfair interference with local land rights, benefit-sharing considerations come into play in the form of procedural and substantive safeguards, in accordance with elements enshrined in the VGGT and as illustrated by human rights jurisprudence. Questions, however, remain regarding the relationship between benefit-sharing and landuse rights, particularly customary ones. That is, empirical research shows that, in many cases, doubtful or strictly monetary benefit-sharing arrangements tend to replace legitimate land-use rights, with detrimental effects for livelihoods and social cohesion. Benefit-sharing can thus be used to reproduce injustices and impose dominant ideological, economic and development models. Literature on the actual implementation of benefit-sharing arrangements via either policy interventions or contractual provisions remains limited, illustrating the need to bridge the gap in legal commentary and provide a comprehensive picture of the socio-legal framework and its implementation on the ground, with focus on two particular issues: the potential mismatch between macro-level benefits at the government level and negative impacts on local-level livelihoods, resulting in unfair distribution of risks and benefits; and procedural shortcomings in the design and implementation of such large-scale agricultural investments, due to a series of structural considerations related to national frameworks characterized by poor governance.

In this context, application of benefit-sharing should include: opportunities for meaningful participation and recognition of legitimate right holders in the decision-making process; safeguards for local land rights; and contractual arrangements for revenue-sharing and non-monetary benefits such as infrastructure development. The VGGT provide guidance both on the protection of legitimate tenure rights and on mechanisms for transparency, participation and accountability in decision-making regarding land allocation.

The overall analysis supports that the concept of fair and equitable benefitsharing has the potential to contribute to sustainable agriculture and rural livelihoods objectives if constructed broadly to cover both the process for its achievement and the substantive outcome. In this sense, benefit-sharing should be understood as integrating mechanisms for information-sharing, technology transfer and capacity-building, dubbed non-monetary benefit-sharing in the research and development realm, and mechanisms for transparency, participation and accountability in decision-making regarding land allocation and use. Enabling conditions, including an inclusive process, are prerequisites for a fair and equitable outcome.

This potential, however, needs to be assessed in the context of the entire international legal architecture affecting land, food and agriculture. Instruments supporting application of fair and equitable benefit-sharing include environmental 
treaties, and those related to human rights and sustainable agriculture. On the other hand, a series of trade- and investment-related agreements promote a neoliberal model of growth within an increasingly hostile political and economic landscape, defined by growing nationalisms, rising authoritarianism and a mistrust of multilateralism. The expanding sphere of application of international trade and investment law, in combination with its enforcement potential and the asymmetry in capacities and power of the parties involved, has resulted in protection of the international capital, often to the detriment of national development priorities in developing countries, restricting states' ability to regulate for the public interest. Trade and investment-oriented policies, including IPRs, are gaining a de facto supremacy over human rights and environmental treaties, because of their enforcement potential and the underlying power of actors and interests involved.

Adoption of the TRIPS Agreement weakened the gains associated with the $\mathrm{CBD}$, while an ever-growing web of bilateral and multilateral free-trade and investment agreements reduces policy choices for developing countries through IPR-related standards and transnational investments on land. The gradual strengthening of plant breeders' rights and the expansion of patents aggravate the asymmetry between modern and farmers' varieties, and limit legitimate possibilities for policy support towards small-scale farming. Large-scale investments in farmland threaten rural livelihoods, radically transforming tenure systems, with well documented impacts on local food security. The activities of multinational companies remain largely outside the scope of international law.

While the general picture of international law appears gloomy at the moment, examples from the grassroots offer rays of hope. The preceding analysis has showcased the role of movements in the development not only of national, but also international, law. Several land rights movements around the globe have been central in land redistribution efforts, as a means towards agrarian and social justice. Agrarian movements have recently been a driving force behind international law development, as illustrated most prominently in the adoption of the UN Declaration of the Rights of Peasants, with La Via Campesina having a leading role in the negotiations. It remains to be seen how the Declaration will be implemented by national governments and applied by courts and whether movements will build on its emancipatory potential to draw attention to agrarian struggles for social justice.

In this context, looking for inspiration at the grassroots level, I explored a series of case studies illustrating community-level understandings of benefitsharing. Of diverse origin, size, participation, focus and visibility, these initiatives illustrate the sharing ethos at the heart of the concept of fair and equitable benefit-sharing, which could affect the acceptability and legitimacy of policy action, within or beyond strict legal frameworks.

Their preliminary analysis provides the background for the research agenda outlined below. The identified trends relate to different aspects of fair and equitable benefit-sharing as a process and an outcome, and aim to enrich its conceptualization to ensure its contribution to addressing global challenges. 
The case studies explored highlighted that the need to empower farmers and affirm their capacities for innovation on-farm, against the full professionalization of breeding and the corporate control of agricultural development, is required for agricultural, environmental and social reasons alike. The legal and institutional context is of vital importance in this regard, and support or lack thereof may have direct impacts on the sustainability of the initiatives. That said, the question of underlying values should be acknowledged and addressed. Choices related to agricultural research, development and production are politically and culturally charged. One community may take a different path to another, and this largely depends to the political predispositions of the members and the socio-cultural context. Furthermore, community organization and community-building is key for the creation and sustainability of bottom-up benefit-sharing mechanisms, as illustrated by the lengthy and complex participatory process that led to the development of the Potato Park benefit-sharing agreement. Addressing participation-related issues is more challenging in less homogeneous groups. Considerable time, effort and good faith is necessary to allow for recognition and empowerment of participants and enable control of the decision-making process, particularly if they come from different backgrounds, and this is a lesson also for international processes of relevance to benefit-sharing. In addition, structures facilitating participation, such as collectives and cooperatives, are a valuable tool for empowerment.

The Potato Park experiment can provide a wealth of lessons to international processes: from the effort and organization put into the participatory process for setting up the agreement, which has also empowered the community to negotiate with outsiders seeking access to its genetic resources and traditional knowledge, to the actual design of the agreement, leading to a sophisticated scheme for intra-community distribution of benefits in relation to needs, capabilities, responsibilities, contributions and efforts.

\section{A research agenda}

How could this analysis fit into the larger idea of agrarian justice? At this stage, the sharing ethos enshrined in the concept of fair and equitable benefit-sharing is in direct conflict with a political and economic system that is increasingly transforming genetic and natural resources and knowledge into commodities. Are there any narratives that link this sharing ethos, as broadly constructed above but poorly applied in practice, with rural struggles for social justice? In the section below, I explore preliminary ideas for future research in the quest for such linkages. I refer to agrarian justice in the general sense proposed by the Transnational Institute, as the political struggles in rural areas around access, control and ownership of resources and land, including international movements struggling against dispossession and working towards alternatives. ${ }^{1}$ A series of narratives have been proposed to frame such struggles, but they are rarely linked to the role of law, from the negotiation and creation of international law to its implementation on the ground. 
The literature on the commons offers a wealth of specific frameworks to be applied, from agricultural research and development and the common pool of genetic resources under the ITPGRFA (Halewood 2013; Frison 2018) to land and natural resource management more generally. The framework on the robustness of social-ecological systems (Anderies et al. 2004) seems to be particularly appropriate for the analysis of social and production systems in rural areas.

The narrative of food sovereignty is another one of these framings. Now enshrined in the UN Declaration on the Rights of Peasants as linked to the right to define food and agriculture systems, and the right to healthy and culturally appropriate food produced through ecologically sound and sustainable methods that respect human rights, food sovereignty was first introduced by La Via Campesina. A comprehensive term, it refers to the agricultural production, distribution and consumption of food, as well as the democratic control of mechanisms for food production and distribution. Integrating environmental sustainability and social justice concepts, food sovereignty creates openings for enriching the still-dominant productivity paradigm stemming from the green revolution, with the need to move towards more biodiverse agricultural production, as a tool for improved nutrition but also agricultural and social resilience, as explored in the second chapter. The impact of the food sovereignty paradigm on the global discourse surrounding rural livelihoods, agricultural development and the right to food stands to be explored, also in light of the implementation of the UN Declaration on the Rights of Peasants. The quest for a transformative vision needs to address also gendered and racialized divisions of farm labor, a topic rarely addressed by scholars working on food and seed sovereignty. In this vein, the impact of regressive, populist and authoritarian national politics on rural areas, and how rural populations are shaped by and interact with these politics, should not be avoided.

Finally, as international lawyers we need to engage with the literature on political ecology and on social movements and to develop the sensibility to take a stance. A prerequisite for this is engaging with theories of justice beyond distribution, to address questions of recognition, difference and political participation. The practices of social movements show the limits of the mainstream human rights discourse and challenge mainstream concepts of international law and politics by emphasizing the autonomy of communities and reinvigorating democracy. As Balakrishnan Rajagopal argued back in 2003, a theory and practice of international law that takes social movements seriously as actors is urgent and essential.

\section{Note}

1 Available at: www.tni.org/en/page/agrarian-justice-works (last accessed 25.2.2020).

\section{References}

Anderies, J. M., Janssen, M. A. and Ostrom, E. (2004) 'A Framework to Analyze the Robustness of Social-Ecological Systems from an Institutional Perspective', Ecology and Society, 9(1): 18. 
170 Conclusions and a research agenda

Halewood, M. (2013) 'What Kind of Goods are Plant Genetic Resources for Food and Agriculture? Towards the Identification and Development of a New Global Commons', International Journal of the Commons, 7(2): 278-312.

Frison, C. (2018) Redesigning the Global Seed Commons: Law and Policy for Agrobiodiversity and Food Security. Abingdon: Routledge.

Rajagopal, B. (2003) International Law from Below: Development, Social Movements and Third World Resistance. Cambridge: Cambridge University Press. 


\section{Index}

access and benefit-sharing (ABS) 10-12, 53, 163-164

Act on the Protection of Plant Varieties and Farmers' Rights (2001), India 30, 79, 84

African Charter on Human and Peoples' Rights 60, 109

African Model Legislation on the Protection of the Rights of Local Communities, Farmers and Breeders (African Union) 31

Agarwal, Bina 57

Agenda 21, 59

Agenda for Sustainable Development (2030) 86, 107, 136

agrarian justice, idea of 4, 129, 133, 168

Agrecol (German NGO) 146

Agreement on a Unified Patent Court 27

agribusiness investments, land contracts for 99-101

'Agricoltura Nuova' cooperative farm 105 agricultural biodiversity $7,69,70$; conservation of $36,75,78,150,151$, 156 ; sustainable use of $55,81,156$; value of 70

agricultural development 2-3, 6, 8, 13, 29, $62,129,164$; corporate control of 156 , 168 ; models of 95,101 ; participation of farmers in 140; and right to food 169 agricultural innovation $8,69,158$ agricultural investments $3,59,61,63,69$, 95, 98-101, 107, 112-113, 115-116, $130-131,166$

agricultural land 95; ownership of 105; transnational investments in 59 agricultural production $2,7,10,21,55$, $63,70-71,82-83,86,91,98,148$, 157,169

agricultural research and development 2,4 , $6,8,11,15,20,21,24,28,41,51,65$,
74-75, 95, 112-114, 128-129, 164-165, 169 ; open-source applications in 135; privatization of 14 agriculture, modernization of 71 agro-ecological systems 87 agro-ecotourism 151-152 Almekinders, Conny 139-140

American Convention on Human Rights 60, 108; Article 21 of 60

Andersen, Regine 77, 79

animal welfare 112; EU regulations on 111 Ankersen, Thomas 88

Argumedo, Alejandro 152-153

Asociación ANDES (Peruvian non-profit association) 17, 148

Awas Tingni case (2001) 60

barley breeding, in Syria 85

Baumaux, Graines 81-82

Bellon, Mauricio 136

beneficiaries, determination of 53-55

benefit-sharing: and access to markets for smallholder farmers 90-95; in agricultural research and development 65 ; application of 101,166 ; determination of the beneficiaries in 53-55; fair and equitable see fair and equitable benefit-sharing; from genetic resource use 53; inter-community agreement on 149, 152; intra-state nature of 53; isle of Ikaria, Greece 110-112; ITPGRFA multilateral approach to 165; in land governance 53; from land use 53; in natural resource use 66; payment rates 23; provisions in CBD and UNCCD on 66-69; from public lands 95-112, 115, 130, 165; regulation of 52; socio-legal framework of 131; traditional knowledge and 53 
Benefit-sharing Fund 17-19, 21, 40, 76, $84,115,128,139,155,164$; priorities regarding on-farm management 139 ; project cycles of 139

BeneLex project 1, 84, 85, 110, 115

Berger, Thierry 63

biocultural community protocol 152, 154

biocultural heritage $4,135,148,150$, 153,155

biodiversity: commercial value of 12 ; conservation of $11,61,90,158$; market-based approaches for management of 12 ; sustainable use of $61,73,87$

biodiversity-based products 12,92

biodiversity conservation $8,19-20,36,42$, $59,63,66-67,71,79,86,90,128,135$, $139,148,158,163$

bioinformatics 24

biopiracy $9,29,38,42 \mathrm{n} 2$

bioprospecting 1

biotechnology industry, emergence of 12

Biotrade Initiative of the UN Conference on Trade and Development 92

Bioversity International 70; Guardians of Diversity in the Mediterranean 147

Bocci, Riccardo 83

Boldrin, Michele 143

Brazilian Landless Rural Workers' Movement (MST) 104, 133; Popular Agrarian Reform 133

Brazilian Seed Act 79

breeding, professionalization of 71,168

capacity-building 17-19, 39-40, 76, 129, 132, 139, 153, 166

CFS High Level Panel of Experts on Food Security and Nutrition 91, 97

CGIAR Consortium 31, 33-35, 139, 149; see also Consultative Group on International Agricultural Research (CGIAR)

Charter of Fundamental Rights of the EU 82

ChemChina 15

Claeys, Priscilla 89, 133

climate change mitigation 59

commercialized value chains 93

Common Agricultural Policy (CAP) 104, 111

common-field agriculture, concept of 149 common heritage: principle of 10 common property 54,96

community-based commercialization systems 87

community-based land and resource management 155-156

Community Biodiversity Use,

Conservation and Development in Asia

Programme (BUCAP) 139-140;

objective of 140

community knowledge systems 151

community management 139

Community Plant Genetic Resources Conservation and Development Project, Vietnam 139

community seed banks $6,138,141,147$

community seed fairs, in Zimbabwe 85

Consultative Group on International Agricultural Research (CGIAR) 7, 8, 10, 17, 38; collections held in trust 12; Fund Council Intellectual Property Group 34, 36; Intellectual Assets (IA) report (2015) 33; IP-related controversies 10, 32; Principles on the Management of Intellectual Assets 32, 33, 36; response on SPIKE gene case 33-35; target beneficiaries of 34; vision of 35 contract farming 85, 93

Convention on Biological Diversity (CBD) 1-2, 11, 51, 53, 61, 66-69, 92, 132, 163; adoption of 11, 12, 39, 163; Akwé: Kon voluntary guidelines $61-62,67-68,92$; on bilateral system of exchanges 16 ; breaches of 28; Conference of the Parties 92; dry and sub-humid lands 67; ecosystem approach 66; influence on FAO 12; respect of traditional knowledge 53, 61; objective on fair and equitable benefit-sharing 2 ; objectives of 12

Convention on the Elimination of All Forms of Discrimination against Women (1979) 57

copyleft licenses: drafting of 146; legal enforceability of 146

copyrights 143

Cotula, Lorenzo 61, 63-64, 98, 99, 133

countries of origin 1-2, 16

crop cultivation and pastoralism 110

crop diversification 70

crop genetic uniformity 8,70

crop varieties: control systems 72 ; uniformization of 71

cultural identity $59,63,150$ 
customary farmer practices and varieties, marginalization of 7,71

customary rights, registration of 58-59, 61-62, 73, 88, 95-97, 103

customary tenure systems $3,61,65,96,98$, 100, 105-106, 132

decision-making 59, 62, 66, 73-75, 78, $100,105,107,109,112-113,116$, $130-132,137,140,153-156,158$, $165-166,168$

deforestation, in Latin America 52, 88

De Jonge, Bram 138

De Schutter, Olivier 29, 42, 74-75, 101

Diamond v. Chakrabarty (1980) 9

digital sequence information 24, 35

disaster risk management 59

dispute settlement, procedures for 26,28 , 64, 97, 114, 132

DNA sequence 14, 30

Doha Declaration (2001) 28

Dow Chemical 15

duality, principle of 149, 153, 157

DuPont 14-15

Earth Summit (1992) 11, 59

eco-community, creation of 148

economic empowerment, of women 107

ecosystem management 66

Edelman, Marc 89, 133

Endorois case (2010) 60

environmental sustainability 2, 4, 55, 98, $112,130,152,157,165$

equal treatment, principle of 82

equitable sharing, of repatriated seeds 152

European Court of Justice 30, 81-82

European Economic and Social Committee 105

European Union (EU): Biotechnology Directive 98/44, 14, 30; Directive 2008/62, 80; Directive 2009/145, 81; Directive 2002/55, 82; Land Policy Guidelines (2004) 107

expression, right of 86

fair and equitable benefit-sharing: access to markets 94; applications of 3, 15-31, 69-112, 132; CBD objective on 2; concept of $1-4,18,30,38,51,65,90$, 131, 165; emergence and application of 2 ; inter-state dimension of 2; IPR instruments on 2; ITPGRFA Multilateral System of 16-31; in land governance 69-112; from land use 3; lessons from the grassroots 133-134; monetary and non-monetary $17-19$; Nagoya Protocol on Access and BenefitSharing 2; objective of 51; from public lands 101-110; with regard to farmers' rights 3; regulation of 3; 'reward-andenable' approach to 129,165 ; status of 15-31, 69-112; trends and challenges 128-133; use of traditional knowledge 2 family farming: agrarian reform and 104; detrimental effects for 105; International Year of 55

farmer-based innovation 25, 137, 148; need for recognition and promotion of 156 farmer field schools 140-141, 156, 158 farmer organizations, collective power of 82,97

farmer practices and seed systems, marginalization of 136

farmers' management systems 70

Farmers' Rights Project 30-31, 77-78, 85

farmers' rights, to benefit-sharing 3; access to markets $90-95$; agricultural biodiversity and 81 ; agrobiodiversity conservation and 80; Bhutan programme for 140; as collective rights 76; concept of 69, 76-78; elements of 75, 90; Global Consultation on 138; and governance of public lands 114; implementation of 78-85; India's legislation on 79; under ITPGRFA 69, 72, 76, 90, 94; in land governance 69-95; legal basis of 72-76; national-level implementation of 76; origin and rationale of 69-72; relation with land rights 86-90; 'reward and enable' approach to 77 ; tenure rights 97 ; violation of 78

farmers' seed systems 74, 84

farmers' varieties 8 ; ITPGRFA

Secretariat on 84 ; marginalizing of 80 ; registration of 84

farm labor, divisions of 169

financial sustainability 139, 156

Food and Agriculture Organization (FAO) 7; influence of CBD on 12; Land Tenure Journal 103; on nations' sovereign rights over their plant genetic resources 12; Resolution 3/91, 12; Resolution 4/89, 72; Voluntary Guide for National Seed Policy Formulation 137 food, right to $3,29,91$; strengthening of PBRs regarding 29 
food safety, regulations of 71, 111

food security 2, 8, 13-14, 16, 18, 21, 36, $54,58,61,63,70,86,91,98,130,132$, 136, 145, 158, 163, 165; farmer cooperatives for 115,166 ; La Via Campesina peasant movement (1996) 86 ; for marginal farming communities 85 ; and nutrition $55,93,106$; through marketing of specialized products 70

food sovereignty 103, 169; and agrarian reforms 115; concept of 86; emergence of 147; governance based on 104, 133-135; in Greece 156; network of 156 ; right to 86

forest carbon stocks 52

Free and Open Source Software (FOSS) 144

Free Software Foundation 143

free-software movement 143

free-trade agreements (FTAs) 88; USA-Morocco FTA 15

French Constitutional Council 83

Frison, Christine 84

Fund Council Intellectual Property Group 33-35

G7 Land Partnership 104

G20 Leaders Declaration (June 2012) 63

Gallico, Leonardo 105

gender equality 57, 106-107

gender gap: in economic wellbeing 57; in ownership and control of property 57 genebanks 7, 16-17, 31, 33, 148

gene patentability $30-31,42$

genetically modified organisms, patenting of 9,29

genetically modified rice 142

genetically uniform crop 7

genetic resources: benefit-sharing from use of 53; bilateral exchanges of 12; countries of origin of $1-2,16$; dematerialization of 24; development of 148; differentiating land use from 52-53; digitalization of 24; indigenous stewardship of 151 ; on-farm management of 83; plant genetic resources see plant genetic resources; principle of national sovereignty over 11-12; privatization of 12,163 ; solidarity economy and innovations associated with 150; use of 1-2; utilization of 17,148

genetic sequences 23-24; functionality of 30 ; patentability of 30 ; patent eligibility of 37 genetic sequence data 24,35

germplasm 8-9, 12, 30, 32, 36, 72, 138, 145, 156; farmers as donors of 72 ; licensing framework 145; patenting of 142

Gilbert, Jérémie 59-60

global food crisis (2008) 59, 90, 98, 113, 130,132

global food production 14, 141

Global Influenza Surveillance and Response System (GISRS) 22-23

Global Information System 19

global proprietary seed market 14

Global South 12, 39, 145

global supply chains 98

GNU General Public License (GPL) 143

GNU Manifesto (1983) 143

Golden Rice 142

grassroots movements 133-134

Great Famine 70

Greek raisin crisis 70

green revolution 7-8, 71, 135-136, 169

Groppo, Paolo 105

Halewood, Michael 11

Hammond, Edward 35

Hardon, Jaap 139

Harvey, David 98

Helfer, Laurence 37

Heller, Michael 77

Hess, Charlotte 9, 96

High- Level Forum on Connecting Smallholders to Markets 93

High Level Panel of Experts on Food Security and Nutrition (HLPE) 91-92, 97

high-quality seeds, availability of 71

Hiroshima Prefecture, Japan 85

Hope, Janet 15

Horneburg, Bernd 146

humanitarian-use licensing 142

human rights: African Charter on Human and Peoples' Rights 60, 109; African framework on 109; Inter-American Court of Human Rights 107-109; jurisprudence 86 ; obligations in investment agreements 64

Ikaria, Greece 110-112

indigenous peoples: collective land rights 58,150 ; customary rights of 59 ; disempowerment of 158; international law regarding rights of 60 ; land rights of 58,99, 150; land tenure situation of 59-62; legal protection and recognition 
of 150; property rights for 150 ; rights and sovereignty of 145 ; right to benefitsharing 151, 154; traditional knowledge of 61; UN Special Rapporteur on the rights of 108,114

indigenous territoriality, development of 150 indigenous vegetable, cultivation of 85 indigenous women, marginalization of 151 information technologies (IT) 12, 142 institutional feeding programmes 92-93 intellectual monopoly 143

intellectual property rights (IPR) 2, 6, 8-9, $13,29,71$; benefit-sharing in patent laws 26-28; CGIAR Consortium on 31; challenges for national implementation 30-31; documentation of 10 ; enforceability of 133,142 ; exceptions to plant breeders' rights and benefit-sharing 25-26; human rights, development and ethical concerns 28-30; impact on legal status of CGIAR collections 10; legal protection against the claiming of 152; licensing terms 143; privatization of genetic resources via 12; researching and negotiating 141; strengthening of 51; WIPO negotiations 28

Inter-American Court of Human Rights 60, 62; Saramaka decision of 107-109

inter-community agreement, on benefitsharing 149, 152-154, 156-157

Inter-Community Fund for BenefitSharing 155

International Convention for the Protection of New Varieties of Plants see UPOV Convention

International Covenant on Civil and Political Rights (ICCPR) 60; Article 27 of 60

International Covenant on Economic, Social and Cultural Rights (ICESCR) $29,42,74-75$

International Crops Research Institute for the Semi-Arid Tropics (ICRISAT) 139

International Institute for Environment and Development (IIED) 148

International Labour Organization (ILO) 60; Convention no. 169 of 60, 150

International Network for Economic, Social and Cultural Rights (ESCR-Net) 109

International Potato Centre (CIP) 149

International Rice Research Institute (IRRI): background of 31-33; benefitsharing and patent protection 31-38; IP
Management Agreement with JIRCAS 38; negotiations with JIRCAS 35; as nonprofit research organization 31; patent applications 33,42 ; on patent eligibility of genetic sequences 37 ; patents on breeding methods associated with rice genes 3, 6; SPIKE gene case 33

International Treaty on Plant Genetic Resources for Food and Agriculture (ITPGRFA) 2-3, 6, 10-12, 16, 29, 34, $38,51,53,72,82,114,137,151$; accumulation of benefits 20-21; adoption of 163; Annex I of 39; Article 12(3)(d) of 33; Article 15 of 32; Benefitsharing Fund 17-19, 21, 40, 76, 84, 128, $139,155,164$; benefit-sharing under farmers' rights in 65; common pool of genetic resources under 169; distribution of benefits 21-22; diversity of users 21; effectiveness of 20; exchanges of MLS material 17; farmers' rights under 69 , 76, 94; fundamental contradiction inherent in 20; Funding Strategy 18; Governing Body 31, 128, 138, 164; IPR-related instruments and benefitsharing 25-31; multilateral approach to benefit-sharing 165; Multilateral System (MLS) of 2, 6, 16-31, 128, 139, 156, 163; negotiations for the revision of the Multilateral System 22-25; objectives of 16 ; policies on farmers' rights 52 ; rationale and structure of 16-20; response on SPIKE gene case 35-37; Standard Material Transfer Agreement (SMTA) 17-19, 23, 32-35, 164

International Year of Family Farming (2014) 55

intra-community distribution, of benefits 158, 168

Irish Potato Famine 70

isolated genes, patenting of 10,37

Jackson, Cecile 57

Japan's international agricultural research agency (JIRCAS) 33, 35; IRRI's negotiations with 35

joint ventures 18

Kanellopoulou, Vasso 148

Kastler, Guy 83

Kelabit community of Bario, Malaysia 85

Kloppenburg, Jack 144, 145-146

knowledge-sharing practices 143 
knowledge, transmission of 153

Kokopelli case (2011) 81-83

Kokott, Juliane 82

Kotschi, Johannes 146

land acquisitions, contestation against 64, 99, 133

land allocation, for benefit of rural poor $54,96,100,105,113,116,130-132$, 165-166

land, commodification of 88

land contracts, for agribusiness investments 99

land distribution 3, 56-57, 103-104, 113, $130,133,165$

land governance 51, 58, 113; emergence of benefit-sharing in 65-66, 67; fair and equitable benefit-sharing in 69-112; farmers' rights and 69-95

land-grabbing 57; concerns related to 105 ; for international investment in farmland 97

land investments, large-scale 98-101, 132

Landless Rural Workers' Movement (MST), Brazil 104, 133

land markets, creation of 58, 97, 101

Land Matrix 99

land ownership 57, 98, 104-105, 110, 111; distribution of 56

land reform: market-assisted 57; in postconflict societies 57; and restitution programme 56-57; state-mandated 56

land registration 97

Land Research Action Network 103

land resources, use of 59-60

land rights: collective 96; domestic law on 58 ; formal rights 58; gendering of 57-58; Greek legislation on 95; of indigenous communities 58, 99, 150; informal rights 58 ; international investment law and 58-59, 63-65; for legal empowerment 102; linking of farmers' rights to 86-90; political significance of 58; of smallholder farmers 62-63; and social conflicts 112 land rush 90, 98

land tenure: global instrument addressing 62 ; governance of 101 ; insecurity of 55 , 71 ; legal recognition for 88 ; management of 58; situation of indigenous peoples 59-62

land use: benefit-sharing from 53; collective rights for 96; difference with genetic resource use 52; for food and agriculture 55-69; isle of Ikaria, Greece 110-112; management of 110 ; regulation of benefit-sharing from 3,52 ; rights of 131

La Via Campesina peasant movement (1996) 86, 89-90, 103, 115, 133

Law of Native Communities and Agrarian Regional Promotion in the Lowlands Forests and Valleys (1974), Peru 150 legal empowerment 101-102, 155

'legitimate' customary rights, definition of 103

Levine, David 143

life, right to 86

living modified organisms, risks arising from 87

living organisms, patentability of 14

local-to-global alliances, of affected people 99, 133

local voices, marginalization of 100

Louaf, Sélim 21, 136, 139, 142

Louwaars, Niels 84

Manzella, Daniele 136

market-based economies 145

medicinal plants 85,151

Mendel Biotechnology 14

Merlet, Michel 97

Michaels, Thomas 145

migration wave of 1890-1910 (Greece) 70

monetary benefit-sharing 19-21, 23, 31, $35-37,40,85,116,129,131,166$; distribution of 21-22

Monsanto 14-15, 30, 79

Monsanto Technology v. Cefetra BV (2010) 30

Morris, Michael 136

Moÿ, Anne-Charlotte 83

Nagoya Protocol on Access and BenefitSharing (2010) 2, 16, 53, 73, 92, 129, $152,154,156$

National Gene Fund (India) 84

national sovereignty, principle of 11,39 ; benefit-sharing and 12; over natural and genetic resources $11-12,53,63,128$, 163; rights of countries 11

National System of Protected Areas (Peru) 150

natural resource: management of 61 ; sustainable use of 86-87

Netscape source code 144

New European Consensus on Development (2017) 107 
'non-commercial' seeds, sale of 83

North-South cooperation 94

Norway's Development Fund 140

nutrition, principles of 74

on-farm management $7-8,78,83,139$

open access 96,142

'open-science' systems 142

open sharing for mutual benefit, principle of 151

open-source applications, in agriculture 4 , $135,138,141-146$

Open Source Initiative 144

open-source licenses: development of 145;

Open Source Seed License 146

open-source programmes 144

Open Source Seed Initiative (OSSI) 4, 135, 145, 156-157; OSSI-Pledged seeds 146; rules for sharing of plant genetic resources 146

Open Source Seed License 146

Ostrom, Elinor 54, 96

Ottoman Empire 110-111

Outcome Document of the Rio+20

Conference (2012) 63

\section{paniyiries 110,112}

Parks, Louisa 84-85, 110, 115

participatory plant breeding 137; analysis

of 136; challenges regarding 137 ;

collaborative programmes 135-141;

concept of 135; objectives of 136;

open-source logic 139; socially and

gender-inclusive 140; as suitable

instrument for empowering farmers 156;

as tool for realizing farmers' rights 138 ;

utilization of farmers' traditional

knowledge 137; in Vietnam 158

Patent Cooperation Treaty (PCT) 28, 33

patent holders' rights, exceptions to 26-28, 41

patent laws: benefit-sharing in 26-28; in Canada 26

patent licensing agreements 36

patents: acceptability of patent applications

34 ; and benefit-sharing 26-28;

eligibility of genetic sequences 37 ; in

field of plant breeding 9; of genetically

modified organisms 9; of germplasm

142; for living organisms 14; ownership

of 15; of PGRFA product 20; on plant

transcriptional regulators 14 ; for

protecting plant-derived innovations 9 peer-production networks 144

Peliti community, in Greece 4, 146-148; aims of 146; community seed bank 147; distribution of traditional seeds 156 ; establishment of 146; free distribution of seeds 147; Greek financial crisis and 147; legal obstacles to farmers' rights 156-157; seed collection expeditions 147

Peschard, Karine 79, 84

plant breeders' rights (PBRs) 8, 13, 41, 79; Africa's policy on 31 ; and benefitsharing 25-26; exceptions under UPOV Convention 25-26; regarding the right to food 29; strengthening of 12, 39, 132,167

plant breeding: farmers' varieties 8 ; patents in the field of 9; Plant Patent Act (1930), US 9; professionalization of 136 plant breeding sector: restructuring of 14 ; support for 145

plant-derived innovations, protecting of 9 plant genetic diversity, availability of 141 plant genetic resources 2; common heritage of 10-11; conservation and diversification of 140; essentially derived varieties 13; ex situ conservation of 83; first wave of privatization 8-10; global governance of 6-15; informal seed systems $6-8,71,80$; nationalization trend for 11-13; newly developed varieties 10; OSSI rules for sharing 146; privatization 2.0 of 13-15; public agricultural research 6-8; sustainable use of $18,80,138$

plant genetic resources for food and agriculture (PGRFA) 6, 7, 9-10, 16, 164; benefit-sharing obligations 17 ; characteristics of 16 ; evolution of governance of 32; patenting of products 20; 'public good' nature of 16; public value of 21; sustainable use of 91, 138; Toolbox for Sustainable Use of 138; users of 17; virtual common pool of 17

Plant Patent Act (1930), US 9

plant variety protection, criteria of 8 , 30-33, 36, 75, 138

Potato Park (Peruvian Andes) 4, 84-85, 148-156; agricultural biodiversity of 149 ; area of 148 ; Association of the Communities of the Potato Park 150; ayllu concept 149; benefit-sharing agreement 168; 
Potato Park (Peruvian Andes) continued collaborative research and development activities 151; communal land-sharing arrangement 149; cultivation of potatoes by Andean farmers 149; customary legal framework 149; ecological sustainability of 149; establishment of 148, 150, 157; genetic resources and knowledge 151; governance of 148; ILO Convention no. 169,150 ; as indigenous biocultural heritage area 148; indigenous peoples living in 149-150; inter-community agreement for benefit-sharing 154; intracommunity relations 149; Law of Native Communities and Agrarian Regional Promotion in the Lowlands Forests and Valleys (1974) 150; Nagoya Protocol with regard to 154; National System of Protected Areas 150; objectives of 150; Potato Park Association 155, 158; potato varieties at 149 ; property rights for indigenous communities 150; Quechua principles 149; repatriation agreement 151; representation towards the Peruvian state 150; right to benefitsharing 151; right to self-determination 148; Sumaq Causay 149; sustainable management of 149

poverty alleviation 101

Prifti, Viola 26-27

private land: as common pastureland

110; in Cusco valley 149; expropriation of 103

privatization, of genetic resources via IPRs 12

professional plant breeding, emergence of 7,135

property rights: bundle of rights 54 ; in common-law systems 54; gender gap in 57; for indigenous communities 150; of owner 54; relationship between

'beneficiaries' and 'rights holders' 54-55

proportionality, principle of 82

proprietary technologies, humanitarian uses of 142

protected commons, concept of 142 , 145-146

public investment, in agriculture 136, 139 public lands: benefit-sharing from 95-112, $115,130,165$; farmers' rights and governance of 114; governance of 9598, 112; large-scale agricultural investments 98-101; legal basis for fair and equitable benefit-sharing from

101-110; ownership of 95; use of 98 public-private partnerships 93

public-sector breeders 17

quality control 72 ; seed certification for 84

Rajagopal, Balakrishnan 169

reciprocity, principle of 10, 149-153, 157

REDD+ project, implementation of 52, 55

Regional Implementation Annex for Africa 61

repatriated seeds, equitable sharing of 152

Repatriation, Restoration and Monitoring of Native Potato Agrobiodiversity and Associated Knowledge of Indigenous Communities, agreement for 151

resilience $18,70,169$

resource management $61,67-68,153$, 155-156, 169

Responsible Investment in Agriculture and Food Systems (RAI) 106

Right to Food Guidelines (2004) 52, 74-75, 91

Rio Earth Summit (1992) 11

Rosset, Peter 103

royalty-bearing 145

Ruppert, Thomas 88

rural livelihoods 3-4, 54, 59, 69, 95, 98-99, 101, 115, 128, 131-132, 166, 167, 169

rural populations: livelihoods of 87 ; rights of $86,115,165$

rural poverty $87,103,147$; instruments to redress 57

safety net $91,147,152,155$

Sainatoudis, Panagiotis 146-148

Salazar, Rene 136-137

Sandwell, Katie 96, 98

saved seeds: exchange and selling of 79; re-use of 13

Schlager, Edella 54

school feeding programme, in Brazil 94

Schweik, Charles 159

seed bank 6, 78, 114, 138, 141, 147

seed certification: marketing and 72, 80, 84, 138; for quality control 84

seed marketing 71; EU legislation on 82-83; farmers' access to 84;

formalization of 136

seed producers, registration procedures for 138 
seed repatriation and conservation 151

seed saving-related knowledge, preservation of 146

Seeds of Survival project (Mali) 85

Sen, Amartya 53

Seyoum, Aseffa 22

Shaheed, Farida 29, 42

sharecroppers 97

Shawki, Noha 90

Sierra Leone 104

slaughter of animals, EU regulations on 112

smallholder farmers 54-55; benefit-sharing and access to markets for 90-95; contribution of 76-77, 90; land rights of 62-63; livelihoods of 7; right to land and water 63

social conflicts 111-112

social function of land: concept of 88-89; definition of 88

social impact assessment 61,108

social justice $2-3,55,56-57,79,102,113$,

$115,134,167-169$

social networks 91

societal transformation 57

socio-economic resilience 70

'socio- environmental' function of land 89

software licenses, charging for 143

Southeast Asian Regional Institute for

Community Education (SEARICE) 140

South-South cooperation 94

SPIKE gene case 31-38; background of 33; response from CGIAR 33-35; response of the ITPGRFA Governing Body 35-37

Stallman, Richard 143

Standard Material Transfer Agreement (SMTA) 17, 39; Article 6(2) of 33; benefit-sharing terms of 20,36; commercial benefits from 20 ; distribution of user-based payments 18 standard of living, right to an adequate 87 subsistence-based agricultural economies 145

subsistence farmers, needs of 9, 25, 136

Sumaq Causay 149

sustainable agriculture $2-4,16,21,36,41$, 76, 78, 90, 95, 99, 114, 129-131, 130, $135,163-167$

sustainable agri-food systems 136

sustainable development 1, 10, 24, 55, 61, 63, 86, 106-107

Sustainable Development Agenda (2030) 107,136
Sustainable Development Goals (SDGs) 94

sustainable land management 58, 61-62, 68-69

sustainable management, of local diversity 7

Svalbard Global Seed Vault 156

Syngenta (Swiss company) 14, 15

System Council Intellectual Property Group see Fund Council Intellectual Property Group

technology transfer 18-19, 40, 68, 129, $132,139,166$

tenure security, of poor households 57,61 , $66,74,97$

trademarks 143

Trade-Related Aspects of Intellectual Property Rights (TRIPS) 9, 12, 167; adoption by WTO 13, 132; Article 27(3)

(b) of 28; Article 30 of 26; exceptions to patent holders' rights $26-28$; provisions on plant variety protection 30 ; violation of 31

traditional farming 91, 149

traditional knowledge 61, 154, 158; Aichi Target on respecting 61; and benefitsharing 53; of indigenous peoples 61 , 66 ; protection of 75,78 ; regarding the improvement of local crops 85; related to natural resource management 68 ; for research and development 53 ; solidarity economy and innovations associated with 150; for sustainable land management 68 ; use of $2,66,151$

traditional resource rights, promotion of 150

traditional seed-saving and exchange practices 13; farmer-led innovation based on 13

tragedy of the anticommons 77, 142

tragedy of the commons 77

transfer of technology 17, 29, 39, 76,129

transgenic plants: BASF's patent in 14; patentability of 14 ; production of 14

Ubuntu (Linux open-source software) 158

UN Convention to Combat Desertification (UNCCD) 3, 61, 66-69; provisions on benefit-sharing 68; Strategic Framework 2018-2030 68; Strategic Plan and Framework 2008-2018 68 
United Nations (UN): Commission on Human Rights 29, 42; Commission on Legal Empowerment of the Poor 101-102; Committee on World Food Security (CFS) 90; Conference on Trade and Development 92; Convention to Combat Desertification (UNCCD) 3, 66-69; Declaration on the Rights of Indigenous Peoples (UNDRIP) 60, 69, 87; Development Programme (UNDP) 7; General Assembly 63, 74, 88, 89; Guiding Principles on Business and Human Rights 107; Human Rights Commission 89; Human Rights Committee 60, 108; Human Rights Council 107; Peasants Declaration 3, 52, 62-63, 76, 86, 102, 108, 113, 115, 117, 129, 130, 133, 165, 167, 169; Special Rapporteur on the Rights of Indigenous Peoples Victoria Tauli-Corpuz 114; Universal Declaration of Human Rights 29,42

UPOV Convention: of 19618 ; of 1978 8-9, 41; of 1991 9, 13, 26, 29, 31, 41; adoption of the TRIPS Agreement 13; benefit-sharing mechanism under 25; breeder's exception under 26; implementation of 29; India's application to 31 ; membership 30; restriction of exemptions to PBRs in 13; sui generis framework of 13; on use of protected varieties 13
USA-Morocco FTA 15

user-based innovation 3, 83, 95, 114

Voluntary Guidelines on the Responsible Governance of Tenure of Land, Fisheries and Forests in the Context of National Food Security (VGGT) 3, 52, $57,61,62,66,69,101-105,114-115$, 130,165

Warriner, Doreen 56, 103

Welch, Eric 22, 142

Westengen, Ola 136

wildlife management 85

Winge, Tone 136, 137

World Food Summit 86

World Health Organization (WHO) 17, 22;

Pandemic Influenza Preparedness (PIP)

Framework 17, 22

World Intellectual Property Organization (WIPO) 14; Intergovernmental Committee on Intellectual Property and Genetic Resources, Traditional Knowledge and Folklore (IGC) 28; negotiations at 28; Patent Cooperation Treaty 28

World Trade Organization (WTO) 9; adoption of the TRIPS Agreement by 13; Agreement on Agriculture 91; on breaches of the CBD requirements 28 ; dispute settlement system 26, 132; negotiations on agricultural subsidies 92 ; negotiations and benefit-sharing 26-28 